Luís Gustavo Haddad

\title{
A PROIBIÇÃO DO PACTO COMISSÓRIO NO DIREITO BRASILEIRO
}

Tese de doutorado em Direito Civil

Orientador: Professor Doutor Alcides Tomasetti Júnior

Faculdade de Direito da Universidade de São Paulo São Paulo

2013 
Banca Examinadora: 


\section{ÍNDICE}

\section{Introdução.}

1.1 Delimitação do objeto .............................................................. 5

1.2 Plano da exposição ............................................................... 9

1.3 Premissas de método ........................................................................ 11

2. Função, e estrutura do pacto comissório.

2.1 As palavras e os sentidos ............................................................... 14

2.1.1 O substantivo pacto ........................................................ 14

2.1.2 O adjetivo comissório .................................................... 16

2.2 Função, no caso do pacto comissório ........................................... 18

2.3 Estrutura do pacto comissório ....................................................... 23

2.3.1 Em que consiste o pacto comissório? ............................... 23

2.3.2 Pacto comissório e obrigações alternativas ...................... 26

2.3.3 Pacto comissório e compra e venda .................................. 28

2.3.4 Pacto comissório e dação em pagamento ......................... 29

2.3.5 Pacto comissório e cláusula penal .................................... 31

2.3.6 Pacto comissório e alienação em garantia ........................ 32

2.3.7 Pacto comissório e realização da garantia ........................ 34

2.3.8 Pacto comissório e retrovenda ......................................... $\quad 36$

3. A proibição do pacto comissório nas legislações estrangeiras e na brasileira.

3.1 A proibição do pacto comissório nas legislações estrangeiras ....... 37

3.1.1 Observação inicial.......................................................... 37

3.1.2 Portugal ................................................................... 37

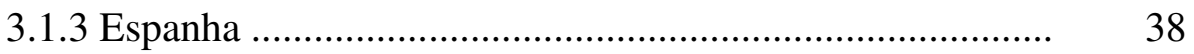

3.1.4 Itália ............................................................................. $\quad 39$

3.1.5 Alemanha .................................................................... 42

3.1.6 França ..................................................................... 43

3.1.7 Argentina ............................................................... 46

3.1.8 Chile ................................................................... 4

3.1.9 México …................................................................ 48 
3.1.10 Estados Unidos da América

3.1.11Resumo analítico ............................................................ 53

3.2 Histórico da proibição na legislação brasileira ............................... 55

3.2.1 Período anterior ao Código Civil de 1916 ...................... 55

3.2.2 Código Civil de 1916 .................................................... 57

3.2.3 Legislação extravagante: Lei n. ${ }^{\circ} 4.728 / 65$, Lei n. ${ }^{\circ}$ 4.864/65 e Decreto-lei n. ${ }^{\circ}$ 911/69 .............................................. 60

3.3 A proibição do pacto comissório no Código Civil .......................... 62

4. Justificativas para a proibição do pacto comissório no direito brasileiro.

4.1 Proteção do devedor ...................................................................... 64

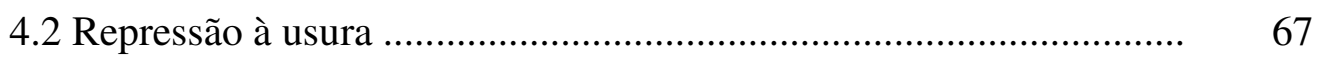

4.3 Caráter inderrogável da via judicial como forma de execução ...... 74

4.3.1 Jurisdição sem Judiciário? ................................................. 76

4.3.2 Realização da garantia sem processo, e atuação da sanção civil, sem processo civil .......................................................... $\quad 80$

4.3.3 Inventário (não exaustivo) das hipóteses de realização da garantia sem processo, no direito vigente ............................... $\quad 82$

(a) Desforço imediato e direito de retenção .................. 82

(b) Direito de vizinhança e servidão ............................... 83

(c) Execução de contrato não cumprido e compensação $\quad 83$

(d) Penhor de créditos e títulos de crédito ..................... 84

(e) Disciplina dos armazéns-gerais, no Decreto n. ${ }^{\circ}$ 1.102, de 21 de novembro de 1903 ......................... $\quad 85$

(f) Art. 63 da Lei n. ${ }^{\circ} 4.591$, de 16 de dezembro de $1964 \quad 86$

(g) Execuções hipotecárias dos artigos 31 e seguintes do Decreto-lei n. ${ }^{\circ} 70$, de 21 de novembro de 1966 .. $\quad 88$

(h) Execução, pela companhia, de quantias devidas pelo acionista remisso. Situação análoga nas sociedades limitadas................................................ 89

(i) Art. 32 da Lei n. ${ }^{\circ}$ 6.766, de 19 de dezembro de 197990

(j) Alienação fiduciária de bens imóveis (Lei n. ${ }^{\circ} 9.514$, de 20 de novembro de 1997) .................................. 90 
(k) Sistema de pagamentos brasileiro (Lei n. ${ }^{\circ}$ 10.214, de 27 de março de 2001)

(1) Execução forçada de acordo de voto

(m) Crédito consignado em folha de pagamento (Lei n. ${ }^{\circ}$ 10.820, de 17 de dezembro de 2003)

(n) Alienação fiduciária no mercado financeiro e de capitais

(o) Nova disciplina da execução no Código de Processo Civil

4.3.4 O que se conclui, a partir desse inventário?

4.4 Interesse social em impedir a difusão do pacto comissório

4.5 Preservação da par conditio creditorum

4.6 Reconstrução de um sentido para a proibição do pacto comissório no direito brasileiro

4.6.1 A licitude do pacto marciano

4.6.2 A disciplina legal das situações em que a garantia já está nominada em dinheiro, no momento do vencimento

4.6.3 A convergência entre esse sentido reconstruído, a estrutura do pacto comissório, a tradição do direito lusobrasileiro e as soluções legislativas estrangeiras

4.6.4 A dação em pagamento posterior ao vencimento

4.7 Resumo do capítulo

4.8 Retorno às questões iniciais

4.9 Sugestões de aperfeiçoamento do direito vigente

5. A proibição do pacto comissório na jurisprudência dos tribunais superiores brasileiros.

5.1 Escopo e plano do capítulo

5.2 As decisões do STF

5.2.1 Recurso Extraordinário n. ${ }^{\circ}$ 60.699/GB

5.2.2 Recurso Extraordinário n. ${ }^{\circ}$ 63.128/SP.

5.2.3 Recurso Extraordinário n. ${ }^{\circ}$ 70.497/RS. 
5.2.5 Recurso Extraordinário n. ${ }^{\circ}$ 82.447/SP.............................. 146

5.2.6 Recurso Extraordinário n. ${ }^{\circ}$ 85.159/PR............................... 151

5.2.7 Recurso Extraordinário n. ${ }^{\circ}$ 86.981/PR.............................. 152

5.2.8 Recurso Extraordinário n. ${ }^{\circ}$ 90.648/SP.............................. 152

5.2.9 Recurso Extraordinário n. ${ }^{\circ}$ 98.947/PR............................... 153

5.3 As decisões do STJ .................................................................. 155

5.3.1 Recurso Especial n. ${ }^{\circ}$ 2.216/SP........................................ 155

5.3.2 Recurso Especial n. ${ }^{\circ}$ 21.681/SP....................................... 157

5.3.3 Recurso Especial n. ${ }^{\circ}$ 41.233/SP......................................... 157

5.3.4 Recurso Especial n..$^{\circ}$ 188.318/ES...................................... 159

5.3.5 Recurso Especial n. ${ }^{\circ}$ 475.040/MG.................................. 159

5.3.6 Recurso Especial n. ${ }^{\circ}$ 158.405/SP.................................... 160

5.3.7 Recurso Especial n. ${ }^{\circ}$ 748.273/GO.................................... 161

5.3.8 Recurso Especial n. ${ }^{\circ}$ 274.588/PR..................................... 161

5.3.9 Recurso Especial n. ${ }^{\circ}$ 998.460/SP..................................... 163

5.4 A trajetória das decisões sobre a proibição do pacto comissório ..... 164

6. O que mais está em jogo na proibição do pacto comissório.

6.1 Pacto comissório e política econômica ........................................... 168

6.2 Tendências internacionais na disciplina das garantias .................... 172

6.3 Profetas, mercadores, agiotas, juristas e atormentados em geral ..... 174

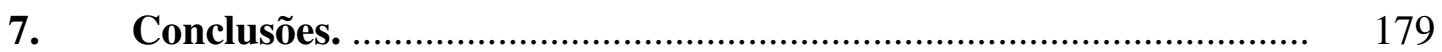

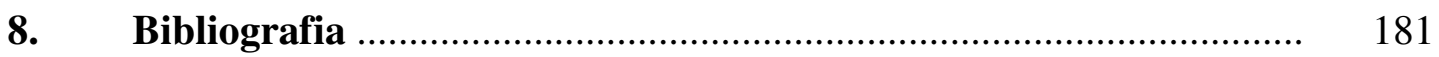

9. Resumos.

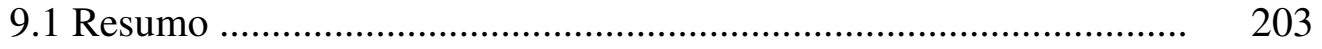

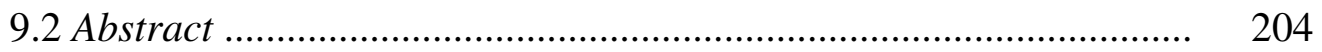

9.3 Résumé …..................................................................................... 205 


\section{INTRODUÇÃO.}

\subsection{Delimitação do objeto.}

O objeto desta tese é a proibição do pacto comissório no direito brasileiro. A respeito dessa vedação, há duas questões centrais que esboçam as fronteiras da pesquisa e constituem pontos de partida da investigação.

A primeira questão está relacionada ao alcance da regra ${ }^{1}$. Estaria ele restrito às garantias reais típicas e nominadas no Código Civil (Lei n. ${ }^{\circ}$ 10.406, de 10 de janeiro de 2002), representadas pelo penhor, pela anticrese e pela hipoteca, ou abrangeria todas as formas de garantia ${ }^{2}$, incluindo a propriedade plena, nos casos em que transferida para assegurar o pagamento de um débito?

\footnotetext{
${ }^{1}$ Este trabalho procurará empregar o termo regra com significado uniforme, aderente à exposição de K. LARENZ em Metodologia da ciência do direito. $2^{\mathrm{a}}$ edição. Trad. José Lamego. Revisão de Ana de Freitas. Lisboa, Calouste Gulbenkian, 1989. p. 297-301. Segundo esse autor, são predicados da regra: (a) sua pretensão de validade, no sentido de representar "uma exigência vinculante de comportamento" ou "uma pauta vinculante de julgamento"; (b) sua incidência generalizada a todo um conjunto de casos da mesma espécie; e (c) a possibilidade de ser expressa por lei, pelo costume ou de estar implícita nas consequências jurídicas impostas pelo direito vigente, ou ainda decorrer de concretizações dos princípios jurídicos.

${ }^{2}$ No direito privado, o termo garantia pode assumir ao menos três significados principais. O primeiro designa um dos elementos da relação jurídica de direito privado, ao lado dos sujeitos, do objeto e do fato jurídico, correspondendo "ao conjunto de providências coercitivas, postas à disposição do titular activo de uma relação jurídica, em ordem a obter satisfação do seu direito, lesado por um obrigado que o infringiu ou ameaça infringir" (C.A. MotA PINTO. Teoria geral do direito civil. $3^{\text {a }}$ edição. Coimbra, Coimbra Editora, 1991. p. 182-183). O segundo e o terceiro sentidos estão presentes na locução garantia das relações jurídicas obrigacionais, designando de modo geral (este, o segundo sentido), o patrimônio do devedor e, de modo específico (este, o terceiro sentido): (a) o patrimônio de outros coobrigados ou corresponsáveis (devedores solidários, fiadores ou avalistas, por exemplo) ou (b) bens destacados do patrimônio do devedor, dos coobrigados ou corresponsáveis, sobre os quais, em qualquer dos casos, incidem: (i) a prioridade na excussão, em caso de inadimplemento, e (ii) o direito de sequela, que conjuntamente caracterizam os chamados direitos reais de garantia. No decorrer deste trabalho, o termo garantia será por vezes empregado no primeiro, por vezes no segundo e por vezes no terceiro desses sentidos, conforme o contexto exija. No que se refere ao terceiro uso, o seu sentido será por vezes mais abrangente, destinando-se a compreender não apenas as garantias pessoais e reais típicas, mas também as garantias atípicas, as transferências de propriedade e de créditos com escopo de garantia, as diferentes formas de alienação ou cessão fiduciária previstas na legislação vigente e os negócios fiduciários em geral. Em resumo, o termo garantia, neste trabalho, por vezes visará a designar não apenas o meio empregado, enquanto fato jurídico (celebração de penhor, hipoteca, alienação fiduciária, v.g.), mas também e principalmente o resultado prático visado, que é o de reforçar ou atribuir vantagens especiais ao credor na realização de seu crédito, em caso de inadimplemento. O que interessa, em última instância, é a função de garantia, mais do que a estrutura escolhida para exercê-la. Sobre os dois últimos dos sentidos aqui identificados, cf. J.M. ANTUNES VARELlA. Das obrigações em geral. v. II. $7^{\text {a }}$ edição. Coimbra, Almedina, 2006. p. 419-421. Em sentido semelhante, P.R. MARTINEZ E P.F. DA PONTE. Garantias de cumprimento. $4^{\text {a }}$ edição. Coimbra, Almedina, 2003. p. 13-15 e L.M.T. MENEZES LEITÃO. Garantia das obrigações. $2^{\mathrm{a}}$ edição. 2008. p. 13-17. Sobre o cumprimento da função de garantia, como critério de aproximação e diferenciação entre direitos reais de garantia e direitos reais em garantia, cf. L.C. PENTEADO. Direitos das coisas.
} 
$\mathrm{O}$ art. 1.365 do Código Civil parece ter pretendido responder, ao menos em parte, a essa primeira pergunta. Esse artigo reproduz, na disciplina da propriedade fiduciária de bens móveis e infungíveis, a regra que já foi aplicável à alienação fiduciária em garantia, por força do art. $66, \S^{\circ}{ }^{\circ}$ da Lei n. ${ }^{\circ} 4.728$, de 14 de julho de 1965 , com a redação dada a esse dispositivo pelo Decreto-lei n. ${ }^{\circ} 911$, de $1^{\circ}$ de outubro de $1969^{3}$. Nessa seara, a jurisprudência do Supremo Tribunal Federal ("STF") por anos debateu, e a do Superior Tribunal de Justiça ("STJ") até hoje discute, conforme se verá no capítulo 5 , se o chamado pacto comissório é proibido apenas nos casos de penhor, anticrese e hipoteca, ou em todos aqueles em que há transferência de titularidade de posições jurídicas, reais ou obrigacionais, com o objetivo de assegurar o pagamento de uma dívida.

Para que se possa raciocinar sobre a extensão da proibição, é preciso formular a segunda das perguntas centrais: qual o fundamento, ou quais os fundamentos, da proibição do pacto comissório? A delimitação do conjunto de situações sujeitas à incidência da vedação exige que se identifique a sua razão de ser, sob a premissa de que ubi eadem legis ratio, ibi eadem legis dispositio ${ }^{4}$. Indaga-se, desse modo, se essa razão de ser está presente apenas nos direitos reais de garantia ou em todos os casos em que se reconhece a constituição ou transferência de posições jurídicas destinadas a funcionar como garantia.

Sob essa perspectiva, a linha de argumentação que compõe o núcleo da tese procurará: (a) enumerar, com recurso às contribuições de autores nacionais e

São Paulo, Revista dos Tribunais, 2008. p. 126-128. Um quarto sentido, menos relevante, mas que merece registro, é aquele refletido no art. 447 do Código Civil. A responsabilidade do vendedor pela evicção, com efeito, é tratada pela lei como uma garantia. O mesmo ocorre com a responsabilidade por vícios redibitórios (art. 445, §2º do Código Civil). Esse quarto sentido, conquanto refletido em regras de direito positivo, não é de interesse desta tese.

${ }^{3} \mathrm{O}$ referido art. 66 da Lei n. ${ }^{\circ}$ 4.728/65 acha-se hoje revogado. Vigora em seu lugar o art. 66-B, por força do disposto na Lei n. ${ }^{\circ} 10.931$, de 2 de agosto de 2004.

${ }^{4}$ Subjaz a esse encadeamento de ideias a premissa do chamado legislador racional, como postulado da atividade hermenêutica que opera a mediação, ou o jogo de tradução e versão, entre a linguagem normativa e a linguagem da realidade, consoante a explicação de T.S. FERRAZ JR.. Introdução ao estudo do direito. Técnica, decisão, dominação. $2^{a}$ edição. São Paulo, Atlas, 1996. p. 278-281. Em outro texto (Ato de julgar e senso de justiça. In: Estudos de filosofia do direito. Reflexões sobre o poder, a liberdade, a justiça e o direito. $3^{\text {a }}$ edição. São Paulo, Atlas, 2009. p. 289-307), o mesmo autor afirma que "a figura do legislador racional fornece a base para a fundamentação da atividade de interpretação dogmática" (p. 298-299). O brocardo latino é comentado por C. MAXIMILIANO. Hermenêutica e aplicação do direito. 16 ${ }^{\text {a }}$ edição. Rio de Janeiro, Forense, 1996. p. 209 e 245. 
estrangeiros, os diferentes fundamentos geralmente apontados para justificar a proibição do pacto comissório; (b) testar a coerência de cada um desses fundamentos com o direito brasileiro vigente; e (c) diante dos resultados alcançados nesse teste, reconstruir um sentido coerente para a regra, que se coadune com a leitura atenta da legislação em vigor. Espera-se que o sentido assim identificado seja capaz de responder às duas questões de início enunciadas, em termos condizentes com as premissas de método expostas no item 1.3.

Os privatistas brasileiros, de modo quase unânime, justificam a proibição do pacto comissório com base no princípio da proteção do devedor ${ }^{5}$, em particular contra práticas usurárias. É o que sustentam, por exemplo, PEREIRA ${ }^{6}$, Bevilacqua $^{7}$, Espínola ${ }^{8}$, FulgênCio ${ }^{9}$, Carvalho de Mendonça ${ }^{10}$, Pontes DE Miranda $^{11}$ Bessone $^{12}$, Silva Pereira ${ }^{13}$, Rodrigues $^{14}$ e Venosa $^{15}$. Penteado,

\footnotetext{
${ }^{5}$ Sobre a existência desse princípio no direito brasileiro, cf. J.C. MOREIRA ALVES. As normas de proteção do devedor e o favor debitoris - do Direito Romano ao Direito Latino-Americano. Notícia do direito brasileiro. n. $^{\circ} 3,1^{\circ}$ semestre de 1997. p. 109-165. Do mesmo autor, O favor debitoris como princípio geral de direito. Revista do advogado. v. 26, n. 88, p. 98-108, nov. 2006.

${ }^{6}$ L.R. PEREIRA. Direito das coisas. v. II. (coleção História do Direito Brasileiro). Brasília, Senado Federal, 2004. p. 21: "Esta proibição [do pacto comissório] tem por fim proteger o devedor, sob a pressão da necessidade de momento, contra as exigências avaras do credor".

${ }^{7}$ C. Bevilacqua. Código Civil dos Estados Unidos do Brasil. v. III. Rio de Janeiro, s/ed., s/d. p. 1229 (comentário ao art. 765): "A proibição do pacto comissório funda-se em um motivo de ordem ética. $O$ direito protege o fraco contra o forte, impede que a pressão da necessidade leve o devedor a convencionar o abandono do bem ao credor por quantia irrisória.".

${ }^{8}$ E. ESPínOLA Os direitos reais limitados ou direitos sobre coisa alheia e os direitos reais de garantia no direito brasileiro. Rio de Janeiro, Conquista, 1958. p. 322: "Para evitar abusos e pressão exercida sobre os devedores necessitados, a lei considera nula qualquer cláusula em que se estabeleça ficar o credor para seu pagamento, com a coisa dada em garantia.".

${ }^{9}$ T. Fulgencio Direito real de hipoteca. v. I. $2^{\mathrm{a}}$ edição, atualizada por José de Aguiar Dias. Rio de Janeiro, Forense, 1960. p. 110-111, segundo o qual a vedação se dá "em proteção ao devedor exposto, sob pressão da necessidade, às exigências avaras do credor; imoral a cláusula, contra os bons costumes".

${ }^{10}$ J.X. CARVAlHo DE MENDONÇA. Tratado de direito comercial brasileiro. $5^{\text {a }}$ edição. v. VI, parte 2. Rio de Janeiro, Freitas Bastos, 1956. p. 631: "No intuito de proteger o devedor contra a própria imprevidência e de impedir que seja vítima da ambição astuciosa do credor, não se permite a cláusula autorizando o credor pignoratício a apropriar-se da coisa empenhada para o pagamento do seu crédito, se a dívida não for paga no vencimento, isto é, o chamado pacto comissório".

${ }^{11}$ F.C. PONTES DE MIRANDA. Tratado de direito privado. t. XX (§ 2.422). $3^{\text {a }}$ edição. São Paulo, Revista dos Tribunais, 1983. p. 30: "O fundamento do art. 765 está em que o pacto comissório, nas garantias reais, poria o devedor à mercê de explorações usurárias.".

${ }_{12}$ D. BesSONE. Direitos reais. $2^{\text {a }}$ edição. São Paulo, Saraiva, 1996. p. 321: "O art. 765, visando prevenir a exploração ou opressão do economicamente fraco (em momento propício, como o em que se acha necessitado de contratar), proíbe a cláusula que autoriza o credor pignoratício, hipotecário ou anticrético a ficar com o objeto da garantia, se a dívida não for paga no vencimento (pacto comissório)".

${ }^{13}$ C.M. DA Silva PereIRA. Instituições de direito civil.v. IV. 15a edição. Rio de Janeiro, Forense, 2001. p. 209-210, onde se lê que o pacto comissório consiste em uma das "maquinações usurárias contra o devedor carente de numerário".
} 
além de reconhecer o propósito de proteção do devedor - o pacto comissório, segundo ele, representaria um excesso de poder, a ser coibido -, aponta a necessidade de tutelar a própria função de garantia, que a seu ver seria deturpada se fosse lícita a contratação da cláusula em apreço ${ }^{16}$.

Ao se consultar os escritos de autores estrangeiros, é possível encontrar um conjunto mais variado de possíveis fundamentos para a proibição do pacto comissório. Com diferentes nuances, conforme mostrará o capítulo 3, o pacto comissório é igualmente vedado na Alemanha (§§ 1.149 e 1.229 do Bürgeliches Gesetzbuch - "BGB”), na Itália (artigos 1.963 e 2.744 do Codice Civile), na Espanha (artigos 1.859 e 1.884 do Codigo Civil) e em Portugal (artigo 694 do Código Civil português). Na França, reforma legislativa datada de 23 de março de 2006 derrubou a proibição do pacto comissório, ao modificar o art. 2348 do Code Civil ${ }^{17}$.

Esse grupo mais amplo de justificativas contempla as seguintes hipóteses, além da já citada tutela do devedor: (a) a proibição do pacto comissório seria um componente da repressão à usura; (b) o pacto comissório, se praticado, violaria o caráter inderrogável da via judicial como meio de realização da garantia da

${ }^{14}$ S. RodRigues. Direito civil. Direito das coisas. v. V. $20^{a}$ edição. São Paulo, Saraiva, 1993. p. 337338: "Com o intuito, portanto, de proteger o devedor, parte mais fraca no contrato, é que o legislador proíbe a convenção de perda do objeto da garantia, em caso de inadimplemento".

${ }^{15}$ S. Venosa. Direito civil. Direitos reais. v. V. $3^{\text {a }}$ edição. São Paulo, Atlas, 2003. p. 473: "o credor poderia facilmente se locupletar da premência do devedor necessitado".

${ }^{16}$ L.C. PENTEADO. Direito das coisas. p. 437. O argumento é compreensível, e cumpre reconhecer sua originalidade, em especial diante do caráter monocórdico das justificativas encontradas na doutrina brasileira. Todavia, ele não deixa de ser, sob certo ângulo, paradoxal: a função da garantia não é justamente a de incrementar a segurança do credor quanto à realização do seu crédito, e o que o pacto comissório promove não é justamente a realização imediata, da garantia e do crédito?

${ }^{17}$ L. AYNES e P. CROCQ. Les sûretés. La publicite foncière. $4^{\mathrm{a}}$ edição. Paris, Defrénois, 2009. p. 239241. Após essa reforma, o citado dispositivo legal passou a vigorar com a seguinte redação: "Il peut être convenu, lors de la constitution du gage ou postérieurement, qu'à défaut d'exécution de l'obligation garantie le créancier deviendra propriétaire $d u$ bien gagé. La valeur du bien est déterminée au jour du transfert par un expert désigné à l'amiable ou judiciairement, à défaut de cotation officielle du bien sur un marché organisé au sens du code monétaire et financier. Toute clause contraire est réputée non écrite. Lorsque cette valeur excède le montant de la dette garantie, la somme égale à la différence est versée au débiteur ou, s'il existe d'autres créanciers gagistes, est consignée.". Em tradução livre: "É lícito convencionar, quando da constituição do penhor, ou posteriormente, que na falta de cumprimento da obrigação garantida o credor se tornará proprietário do bem empenhado. O valor do bem deverá ser determinado na data da transferência por um especialista designado de comum acordo ou judicialmente, salvo se existir cotação oficial do bem em um mercado organizado conforme definido no Código Monetário e Financeiro. Toda cláusula em sentido contrário é reputada não escrita. Se o valor do bem empenhado exceder o montante da dívida garantida, a soma correspondente a esse excesso deve ser revertido ao devedor ou, caso existam outros credores pignoratícios, consignado." 
relação jurídica e, por conseguinte, do crédito; (c) haveria um interesse social em coibir a difusão do pacto comissório; e (d) o pacto comissório, se praticado, implicaria afronta ao princípio da par conditio creditorum, e significaria a subtração indevida, ou desproporcional, de bens do patrimônio do devedor, em prejuízo dos demais credores ${ }^{18}$. Uma das tarefas principais a que se propõe esta tese é confrontar cada um desses possíveis fundamentos com as regras do direito positivo brasileiro. Dela ocupa-se o capítulo 4.

Os demais capítulos orbitam em torno desse cerne. Ora para preparalo, como ocorre com os capítulos que o antecedem, ora complementa-lo, como é o caso dos que lhe são subsequentes, como se passa verá no plano da exposição.

\subsection{Plano da exposição.}

Este capítulo introdutório será completado com a indicação das premissas de método (item 1.3). Em seguida, o capítulo 2 procurará perquirir os sentidos dados pelo uso, na linguagem jurídica, do substantivo pacto e do adjetivo comissório. Isso servirá como prólogo (i) à identificação da função que seria desempenhada pelo pacto comissório, se ele fosse lícito; e (ii) à descrição das possíveis leituras estruturais dessa cláusula, o que também se fará sob a hipotética premissa de sua licitude. Nesse esforço de análise estrutural, serão observadas as correlações entre o pacto comissório e as figuras das obrigações alternativas, da compra e venda, da dação em pagamento, da cláusula penal, da alienação em garantia, da realização da garantia e da retrovenda.

O capítulo 3 será dedicado, em primeiro lugar, a fornecer um panorama, predominantemente legislativo - e não exatamente jurídico - da proibição do pacto comissório em outros ordenamentos que não o brasileiro. Nesse

\footnotetext{
18 Dentre outros, identificam e analisam, no direito italiano, as diferentes razões normalmente apontadas para justificar a proibição C.M. BIANCA. Il divieto del patto comissório. Milano, Giuffré, 1957. p. 202-218; U. CARNEVAlI. Patto comissório (voce). In: Enciclopedia del diritto. XXXII. Milano, Giuffré, 1982. p. 499-506; e V. ANDRIOLI. Commentario del Codice Civile a cura di Antonio Scialoja e Giuseppe Branca. Libro Sesto. Tutela dei diritti. Art. 2.740-2.899. Bologna, Nicola Zanichelli Editore, 1945. p. 49-54. Abordagens semelhantes, na Espanha e em Portugal, podem ser encontradas, respectivamente, em M.I. FELIU REY. La prohibicion del pacto comissório y la opcion en garantia. Madrid, Editorial Civitas, 1995. p. 66-88; e I. A. DE MATOS. O pacto comissório. Contributo para o estudo do âmbito da sua proibição. Coimbra, Almedina, 2006. p. 56-75.
} 
mapeamento, será verificada a presença da vedação: (a) nas principais legislações que representam o que se poderia chamar de direito continental europeu ${ }^{19}$; (b) em certos países da América Latina (Argentina, Chile e México); e (c) nos Estados Unidos da América, dada a notável influência das leis norte-americanas em recentes reformas legislativas sobre o tema das garantias de financiamentos, ocorridas em países de tradições jurídicas tanto semelhantes quanto distintas ${ }^{20}$. A segunda parte do capítulo 3 esboçará breve histórico das regras que, no direito brasileiro, deram corpo à proibição do pacto comissório. Por fim, serão abordados os contornos da proibição, tal como ela hoje se apresenta no Brasil.

Após o capítulo 4 - em que as justificativas para a vedação do pacto comissório serão contrastadas com o direito positivo brasileiro - será empreendida, no capítulo 5, uma análise das principais decisões do STF e do STJ que debateram o alcance da proibição do pacto comissório.

O capítulo 6 contém complementações, relativamente digressivas, sobre questões da economia e da cultura que se entende estarem envolvidas na proibição do pacto comissório.

O sétimo e último capítulo procurará qualificar as conclusões alcançadas ao longo do trabalho como contribuição original à ciência jurídica brasileira.

\footnotetext{
${ }^{19}$ Sobre o que comungam os diferentes direitos nacionais dos países da Europa continental, e que permite o uso de uma locução como direito continental europeu, cf. F. WIACKER. História do direito privado moderno. Trad. A. M. Botelho Hespanha. Lisboa, Calouste Gulbenkian, 1980. p. 7-14. O uso nesta nota do verbo comungar não é gratuito; muito do que subjaz ao "caráter comum dos problemas sociais e jurídicos, das instituições e dos fundamentos espirituais" (obra citada, p. 7-8) dos países europeus reside nas raízes históricas da noção de cristandade, cf. J. LE GofF. As raízes medievais da Europa. Trad. Jaime A. Clasen. Petrópolis, Editora Vozes, 2007. p. 279-284. Também sobre os aspectos comuns às experiências jurídicas da Europa continental, cf. P. KOSCHAKER. Europa y el derecho romano. Trad. José Santa Cruz Teigeiro. Madrid, Editorial Revista de Derecho Privado, 1955; e, mais recentemente, A.M. HESPANHA. Cultura jurídica europeia. Coimbra, Almedina, 2012 (em particular em seus capítulos 6 e 7).

${ }^{20}$ Cf. H. SIGMAN. Security in movables in the United States - Uniform Commercial Code Article 9: a basis for comparison. In: Security Rights in Movable Property in European Private Law. Edited by Eva-Maria Kieninger. Cambridge: Cambridge University Press. 2009; e C. DE CORES e E. GABRIELLI. El nuevo derecho de las garantias reales. Estudio comparado de las recientes tendencias en materia de garantias reales mobiliarias. Bogotá, Temis, 2008.
} 


\subsection{Premissas de método.}

Esta tese pretende realizar um exercício de argumentação jurídica, tomada no sentido desenvolvido por autores como ALEXY $^{21}$ e MACCORMICK ${ }^{22}$. A argumentação jurídica, nesse marco teórico, é a forma de elaboração e expressão do raciocínio e do discurso jurídico como um caso especial do raciocínio e do discurso prático em geral.

Segundo ALEXY, tanto o discurso jurídico como o discurso prático: (a) têm como centro controvérsias sobre questões práticas, isto é, sobre que conduta deve ser adotada em uma situação concreta; e (b) discutem essas controvérsias tomando como norte a ideia de correção, que supõe a existência de critérios pelos quais se possa criticar a conduta em apreço.

As diferenças entre razão jurídica e razão prática decorrem de certas limitações peculiares à razão jurídica. Dentre elas, a mais relevante é a vinculação ao direito vigente ${ }^{23}$. MACCORMICK resume o significado da correção no discurso prático ou na razão prática nos seguintes termos: (a) não deve haver afirmações sem justificativas que as sustentem; (b) tudo o que é afirmado pode ser questionado; e (c) diante de um questionamento, uma justificativa para ele também deve ser construída ou indicada ${ }^{24}$.

O esforço metodológico da tese envolve também o que o mesmo MACCORMICK descreve como reconstrução racional $^{25}$. Cuida-se, em síntese, de um projeto de interpretação e elucidação de conjuntos de enunciados normativos. Nesse projeto, o material bruto sobre o qual o intérprete se debruça é analisado, decomposto, para ser depois reconstruído segundo critérios de coerência e

${ }^{21}$ R. AlEXY. Teoria da argumentação jurídica. A teoria do discurso racional como teoria da fundamentação jurídica. Trad. Zilda Hutchinson Schild Silva e revisão técnica de Claudia Toledo. São Paulo, Landy Editora, 2005.

${ }^{22}$ N. MACCORMICK. Argumentação jurídica e teoria do direito. Trad. Waldea Barcellos. São Paulo, Martins Fontes, 2006; e Rhetoric and the Rule of Law. A theory of legal reasoning. Oxford, Oxford University Press, 2005.

${ }^{23}$ R. ALEXY. Teoria da argumentação jurídica. p. 210-217.

${ }^{24}$ N. MACCORMICK. Rhetoric and the Rule of Law. p. 17.

${ }^{25}$ N. MACCORMICK. Rhetoric and the Rule of Law. p. 29. 
ordenação, de modo a se fazer mais compreensível. Em suas próprias palavras: “This is an intellectual process involving a new imagining and describing of the implicit order in potential disorder, based on some principles or values ascribed to the whole and its parts" ${ }^{\prime 26}$. É precisamente o que se pretende realizar com as regras, decisões judiciais e manifestações doutrinárias que tratam da proibição do pacto comissório ou com ela guardam relações importantes.

O trabalho está largamente apoiado, ademais, na chamada hipótese do legislador racional. FERRAZ JR. explica que a hipótese do legislador racional é crucial para conferir justificativas e fundamentos para a atividade de interpretação desempenhada pela dogmática jurídica ${ }^{27}$. $\mathrm{O}$ método daí decorrente não assegura que se alcançará uma interpretação correta ou verdadeira para as regras estudadas. Todavia, ele permite identificar interpretações "justificadas ou não justificadas a partir de certos postulados de competência ou máximas de racionalidade", que se expressam em um assim chamado código forte, isto é, um sistema unitário e racional de conhecimentos e preferências ${ }^{28}$. A análise crítica das diferentes e possíveis justificativas para a proibição do pacto comissório, à luz da legislação vigente, toma por pressuposto exatamente a existência desse "sistema unitário e racional de preferências", que se postula esteja implícito no direito positivo.

Por fim, cabe dizer que a exposição dará prioridade, desde o início, a construir a pretendida contribuição original à ciência jurídica brasileira. Tanto quanto possível, serão evitadas sistematizações exaustivas da literatura pretérita sobre os temas, e simples resenhas do pensamento de outros autores que não se mostrem decisivas para a elaboração dos argumentos próprios à visada contribuição original. O autor desta tese já concluiu mestrado em direito civil ${ }^{29}$. É para a obtenção desse último título que se deve demonstrar "capacidade de sistematização crítica da literatura existente sobre o tema tratado e capacidade de utilização dos métodos e

\footnotetext{
${ }^{26}$ N. MACCORMICK. Rhetoric and the Rule of Law. p. 29. Em tradução livre: "Este é um processo intelectual que envolve uma nova imaginação e descrição da ordem implícita na potencial desordem, baseado em determinados princípios e valores atribuídos a um todo e suas partes".

${ }^{27}$ T.S. FERRAZ JR.. Ato de julgar e senso de justiça. In: Estudos de filosofia do direito. Reflexões sobre o poder, a liberdade, a justiça e o direito. $3^{\text {a }}$ edição. São Paulo, Atlas, 2009. p. 289-307

${ }^{28}$ T.S. FERRAZ JR.. Ato de julgar e senso de justiça. p. 299.

29 L.G. HADDAD. Função social do contrato: um ensaio sobre seus usos e sentidos. São Paulo, Dissertação de mestrado apresentada à Faculdade de Direito da Universidade de São Paulo, 2009.
} 
técnicas de investigação científica, tecnológica ou artística" (art. $7^{\circ}$ do Regimento de Pós-Graduação da Universidade de São Paulo). Por isso, entre as alternativas de demonstrar amplo empenho em pesquisa e sistematização, de um lado, e de caminhar de modo mais direto e crítico em direção aos pontos centrais da discussão, há uma escolha convicta pela segunda delas.

As referências bibliográficas seguem, no essencial, o padrão da norma NBR 6023/2002, da Associação Brasileira de Normas Técnicas - ABNT. 


\section{FUNÇÃO, E ESTRUTURA DO PACTO COMISSÓRIO.}

\subsection{As palavras e os sentidos.}

\subsubsection{O substantivo pacto.}

Na linguagem do direito privado, não há dúvidas, nem ambiguidades relevantes, no uso do substantivo pacto. Segundo TeIXEIRA DE FreITAS, os pactos são "contratos acessórios de outros contratos" e são todos "adjetos, isto é, acessórios dos contratos, em que aparecem eles estipulados" "30. Essa explicação sobre o sentido do termo pacto é interessante, pois ela tanto esclarece como confunde, ao se valer de uma figura de linguagem - a diácope - que embaralha os significados dos termos pacto e contrato. Na linguagem comum, os sentidos do que é contratado e do que é pactuado são conjuminados ${ }^{31}$.

No direito romano clássico, porém, havia uma diferença bastante relevante, enraizada na fratura que separava os conteúdos negociais contratados, de um lado, e os conteúdos negociais apenas pactuados, de outro lado ${ }^{32}$. Existia um conjunto de composições de interesses (assetto di interessi, na dicção de BETTI), que embora fossem ajustadas entre as partes, eram insuscetíveis de gerar vinculum iuris, segundo o direito quiritário. Isso ocorria em oposição a composições de interesses que, conquanto igualmente avençadas, tinham respaldo na ordem jurídica suscetível de promover a criação de vinculum iuris. Para BETTI, esse apoio relaciona-se com a noção de tipicidade dos $\operatorname{contratos}^{33}$. Esse mesmo autor reconhece que essas duas modalidades de composição de interesses eram iguais "sob o aspecto estrutural da fattispecie exterior, 34 . Tal identidade, todavia, não afastava a diferença capital entre os respectivos efeitos jurídicos, que no caso dos meros pactos eram sensivelmente mais limitados, ou sequer reconhecidos, pelo ius civile. Essa limitação de eficácia

\footnotetext{
${ }^{30}$ A. TeIXEIRA DE FreitAs. Vocabulário jurídico. t. I. (Coleção clássicos do direito brasileiro. Edição cuidada por Alcides Tomasetti Jr.). São Paulo, Saraiva, 1983. p. 253-254.

${ }^{31}$ M.A. COELHO DA RoCHA. Instituições de direito civil portuguez. t. II. $2^{\mathrm{a}}$ edição. Coimbra, Imprensa da Universidade, 1848, p. 579: "Entre nós porém os nomes de convenção, contracto, pacto, estipulação, são ordinariamente empregados como synonimos".

${ }^{32}$ Sobre essas distinções, a exposição toma por base E. BETTI. Istituzioni di diritto romano. v. 2. Parte prima. Padova, Cedam, 1962. p. 182-187.

${ }^{33}$ E. BETTI. Istituzioni di diritto romano. v. 2. p. 183. Tradução livre.

${ }^{34}$ E. BETTI. Istituzioni di diritto romano. v. 2. p. 183. Tradução livre.
} 
jurídica decorria da circunstância de os chamados pactos não corresponderem "a uma função econômico-social da autonomia privada que seja idônea, segundo a valoração do ordenamento jurídico" para gerar efeitos iguais aos dos contratos propriamente $\operatorname{ditos}^{35}$. A eficácia dos pactos, por outro lado, projetava-se no terreno do direito dos pretores, como fundamento de exceções aplicáveis a contratos protegidos pela chamada iudicia bonae fidei. Os pactos desempenhavam, na maior parte dos casos, caráter acessório ou mesmo complementar em relação ao contrato. Por vezes, os pactos cumpriam funções independentes, tanto positivas - para permitir o exercício de um direito, por exemplo -, como negativas, isto é, para paralisar pretensões previamente constituídas ${ }^{36}$.

Hoje, a distinção entre contrato e pacto decanta-se na ideia de que o pacto constitui uma cláusula ou acordo singular, acessório e paralelo a um contrato principal, de conteúdo mais amplo ${ }^{37}$. É esse, apenas, o sentido do termo na locução pacto comissório. Não há mais, no uso da palavra, sentidos explícitos ou implícitos relacionados à estatura dos efeitos jurídicos dele decorrentes, nem à respectiva licitude. O uso do termo pacto, nos dias que correm, aparece (a) em situações de ilicitude, v.g. pacto comissório e pacta corvina (cláusulas que versem sobre herança de pessoa viva, conforme art. 426 do Código Civil); e (b) em situações de licitude, v.g., pacto de retrovenda (art. 505 a 508 do Código Civil $^{38}$ ) e pacto de melhor comprador $^{39}$. A própria expressão pacto comissório é corretamente utilizada, ao abrigo da licitude, para designar a previsão negocial de resolução ipso iure do contrato de compra e venda, ou de contratos bilaterais, de modo geral, por inadimplemento. É o que se via, por exemplo, no título do art. 1.163 do Código Civil de $1916^{40}$. No Código Civil, o art. 474 fala de "cláusula resolutória", que pode ser expressa ou tácita. A modalidade expressa - que opera de pleno direito - guarda

\footnotetext{
${ }^{35}$ E. BETTI. Istituzioni di diritto romano. v. 2. p. 183-185.

${ }^{36}$ E. BETTI. Istituzioni di diritto romano. v. 2. p. 184. As explicações de BETTI não destoam daquelas apresentadas por TALAMANCA. Esse último autor chama a atenção para uma passagem do Digesto (D. 2.14.7.5) em que Ulpiano distingue os pactos contemporâneos à celebração do contrato, chamados adjetos ou incontinentes, e os pactos chamados ex intervallo, avençados de modo posterior e separado do contrato principal.

${ }^{37}$ V. RoPPO. Il contratto (Tratatto di diritto privato, a cura di Giovanni Iudica e Paolo Zatti). Milano, Giuffrè, 2001. p. 20.

${ }^{38}$ F.C. PONTES DE MIRANDA. Tratado de direito privado. t. XXXIX. $3^{\text {a }}$ edição. São Paulo, Revista dos Tribunais, 1984. p. 157.

${ }^{39}$ F.C. PONTES DE MIRANDA. Tratado de direito privado. t. XXXIX. p. 189.

${ }^{40}$ F.C. PONTES DE MIRANDA. Tratado de direito privado. t. XXXIX. p. 197 e seguintes $(\$ \S 4.308$ e 4.309).
} 
sentido equivalente ao do pacto comissório referido no art. 1.163 do Código Civil anterior.

\subsubsection{O adjetivo comissório.}

Se o substantivo pacto não suscita ambiguidades importantes, o mesmo não ocorre com o adjetivo comissório e, por consequência, com as locuções lex comissoria ou pacto comissório. Essas duas últimas expressões são usadas, por exemplo, por TEIXEIRA DE FREITAS, para designar o pacto pelo qual, na falta de pagamento do preço, resolve-se de pleno direito a compra e venda ${ }^{41}$. No Vocabulario jurídico, do mesmo autor, a definição é mais ampla, não se restringindo ao contrato de compra e venda: "é a clausula dos contratos bilaterais, pela qual uma das partes ressalva o direito de não cumprir as obrigações dele, se a outra parte deixa de cumprir as suas" ${ }^{42}$. Segundo PONTES DE MIRANDA, cuida-se de direito (ou melhor, poder) formativo resolutivo, que, nos direitos lusitano e luso-brasileiro, já contava com previsão legal desde a época das três Ordenações ${ }^{43}$. Trata-se de significado distinto daquele refletido nos artigos 1.365 e 1.428 do Código Civil, relacionados à disciplina da propriedade fiduciária, da hipoteca, do penhor e da anticrese. É somente desse último sentido que este trabalho busca se ocupar.

A pergunta que se segue, diante desses dois usos, é se haveria algo de comum entre as duas situações sobre as quais recai o sentido do pacto comissório. A resposta é positiva. Em ambos os casos, sobressai a circunstância de os pactos terem, por cerne das suas fattispecies ${ }^{44}$, o inadimplemento, e de o tomarem como pressuposto da irradiação de determinados efeitos jurídicos ${ }^{45}$.

\footnotetext{
${ }^{41}$ A. TeIXEIRA DE FreitAs. Consolidação das leis civis. v. I. Edição fac-similar. Brasília, Superior Tribunal de Justiça, 2003. p. 350 (art. 532 e respectiva nota 25). No mesmo sentido, cf. artigos 2.072 a 2.074 do Esboço. v. 2. Brasília, Ministério da Justiça, 1983. p. 376.

${ }^{42}$ A. TEIXEIRA DE FREITAS. Vocabulario jurídico. t. I. p. 253.

${ }^{43}$ F.C. PONTES DE MIRANDA. Tratado de direito privado. t. XXXIX. p. 198. A jurisprudência também consagra esse uso da locução "pacto comissório", vinculado a contratos de compra e venda, como se vê nas decisões do STJ no âmbito do Recurso Especial n. ${ }^{\circ}$ 101.571/MG. Quarta Turma. Rel. Min. Ruy Rosado de Aguiar. j. 14.05.2002 e do Recurso Especial n. ${ }^{\circ}$ 332.802/MS. Quarta Turma. Rel. Min. Luis Felipe Salomão. j. 10.02.2009; ambos consultados em www.stj.gov.br; acesso em 11.12.2012.

${ }^{44} \mathrm{O}$ termo fattispecie é empregado com o significado de "figura do fato", proposto por E. BETTI. Teoria geral do negócio jurídico. t. I. Trad. Fernando de Miranda. Coimbra, Coimbra Editora, 1969. p. $17-20$.

${ }^{45}$ Nesse sentido, A. BuRdeSE. Lex commissoria e ius vendendi nella fiducia e nel pignus. Torino, Giappichelli, 1949. p. 12-15.
} 
O termo comisso tem origem na palavra latina comissum, que designa a "pena, em que incorre aquelle que a estipulou em algum contrato, se faltasse às leis, e condições convencionadas"; o adjetivo "comissória", por sua vez, designaria a "cláusula, cuja inexecução opera a nulidade do contrato" ${ }^{46}$. Ao dissecar a locução latina "lex commissoria", SCHULZ associa o adjetivo à expressão "committitur fiducia", que equivaleria à afirmação de que "la fiducia es decomisada"47. Na legislação brasileira, o termo aparece com sentido próximo ao aqui descrito no art. 107, $\S 4^{\circ}$, da Lei n. ${ }^{\circ} 6.404$, de 15 de dezembro de 1976. Ao estabelecer os poderes que assistem à companhia em caso de mora do acionista no cumprimento da obrigação de integralizar as ações subscritas, esse dispositivo atribui à companhia a faculdade de "fazer suas as entradas realizadas, integralizando-as com lucros ou reservas, exceto a legal". Na ausência desses lucros ou reservas, a norma confere o prazo de um ano para a companhia alienar "as ações caídas em comisso" 48 . Não é constante, como se vê, a vinculação entre a hipótese e a sanção de nulidade.

O adjetivo comissório, portanto, qualifica, de modo amplo, o pacto que prevê o descumprimento e, diante dele, impõe consequências automáticas e adversas à parte inadimplente. No caso da compra e venda, ou dos contratos bilaterais de modo geral, pacto comissório é aquele que - sendo lícito - autoriza a parte adimplente o promover a resolução do contrato, em caso de inadimplemento da contraparte. No caso das garantias reais típicas - propriedade fiduciária, hipoteca, penhor e anticrese -, o uso do adjetivo pela lei predica o pacto ilícito pelo qual, na ocorrência do inadimplemento, opera-se a transferência definitiva, para o credor, da propriedade sobre o bem objeto da garantia ${ }^{49}$. É nesse último sentido, isto é, como

${ }^{46}$ A. de Moraes Silva. Diccionário da língua portugueza, composto por Antonio de Moraes Silva. t. I. $4^{\mathrm{a}}$ edição. Lisboa, Na impressão régia, 1831. p. 415. No mesmo sentido, LAUDELINO FREIRE. Grande e novíssimo dicionário da língua portuguesa. v. II. Rio de Janeiro, José Olympio Editora, 1957. p. 1.477; e também CAUDAS AUlETE. Verbete "comisso". Consultado em http://aulete.uol.com.br; acesso em 08.06.2012.

${ }^{47}$ F. SCHUlz. Derecho romano clásico. Trad. José Santa Cruz Teigeiro. Barcelona, Bosch, 1960. p. 396.

${ }^{48}$ M. CARVAlHOSA, em comentário a esse artigo, equipara essa previsão legal a um autêntico pacto comissório. Comentários à lei de sociedades anônimas. $2^{\circ}$ v. $4^{\mathrm{a}}$ edição. São Paulo, Saraiva, 2008. p.289-292. A regra repete, sem alterações significativas, o que já constava do art. 77 do Decreto-lei n. ${ }^{\circ}$ 2.627, de 26 de setembro de 1940, que também se valia da expressão "ações caídas em comisso".

${ }^{49}$ Além dos já citados artigos 1.365 e 1.248 do Código Civil, é com esse significado que a locução aparece, por exemplo, no art. 2.744 do Codice Civile, cf. V. RopPO. Note sopra il divieto del patto comissorio. In: Rischio contrattuale e autonomia privata. Napoli, Jovene, 1982. p. 259-277. 
componente da disciplina jurídica das garantias reais das relações jurídicas obrigacionais, que o pacto comissório interessa a esta tese.

\subsection{Função, no caso do pacto comissório.}

$$
\begin{aligned}
& \text { "O que mais alarma o industrial ou o } \\
& \text { comerciante de nossos dias não é tanto, } \\
& \text { como sucedia com seus predecessores, o } \\
& \text { incêndio do estabelecimento ou de suas } \\
& \text { fazendas, riscos contra os quais já se } \\
& \text { dispõe atualmente de adequada proteção, } \\
& \text { mas as incertezas do mercado e, dentre } \\
& \text { estas, a impontualidade ou insolvabilidade } \\
& \text { dos clientes." }
\end{aligned}
$$

Fala-se aqui em "função, no caso do pacto comissório", e não em “função do pacto comissório". É preciso cautela ao se propor uma apreciação funcional do pacto comissório. O mesmo cuidado justifica a vírgula, que aparece no título do capítulo. O termo função é plurívoco na linguagem jurídica ${ }^{51}$. Entre os diferentes sentidos em que pode ser empregado, há dois, em especial, que precisam ser extremados, para fins de estudo do pacto comissório.

De um lado, existe a função que orienta o exercício das posições jurídicas ativas. Trata-se de sinônimo da locução legal "fim econômico ou social", que estabelece limites ao exercício das referidas posições. Trata-se dos limites que, se forem manifestamente excedidos, ensejarão o ilícito previsto no art. 187 do

${ }^{50}$ F.K. COMPARATO. O seguro de crédito. São Paulo, Revista dos Tribunais, 1968. p. 9-12 e 26-31. Do mesmo autor, sobre o mesmo tema, cf. Notas retificadoras sobre seguro de crédito e fiança. In: Direito empresarial. Estudos e pareceres. São Paulo, Saraiva, 1995. p. 438-449.

${ }^{51}$ Já se procedeu a uma análise dos diferentes sentidos da função, na linguagem jurídica, em L.G. HADDAD. Função social do contrato: um ensaio sobre seus usos e sentidos. p. 35-51. Foram destacados, nessa oportunidade: (a) o sentido originário do direito público, relacionado à noção de munus ou função pública; (b) o sentido de situação jurídica subjetiva, entendida como complexo de poderes (em sentido amplo) outorgados para a tutela de interesses alheios aos do titular dos poderes (v.g. poder familiar e poder de controle nas companhias); (c) o sentido da análise funcional dos institutos jurídicos; e (d) o sentido advindo da sociologia jurídica, que diz respeito aos efeitos econômicos e sociais das normas jurídicas e que está refletido na obra de K. RENNER. The institutions of private law and their social functions. Trad. Agnes Schwarzchild. London, Routledge \& Kegan Paul, 1949. 
Código Civil ${ }^{52}$. Outro exemplo desse significado consta do art. $5^{\mathbf{o}}$ da Lei de Introdução ao Código Civil, como diretriz para a aplicação da lei pelo juiz. Em matéria de pacto comissório - que é ilícito no direito vigente - é incabível cogitar desse sentido da função.

O segundo significado da função para o qual se quer atentar não é incompatível com o raciocínio jurídico sobre o pacto comissório. Não, ao menos, nos mesmos termos em que se essa incompatibilidade se impõe ao referido primeiro sentido. Esse segundo significado é tributário da obra de RENNER, e diz respeito conjunto dos efeitos sociais e econômicos gerados pela utilização da cláusula, que pode se infiltrar na prática contratual, a despeito de sua ilicitude ${ }^{53}$. Tem-se aqui uma função apreciada sob uma perspectiva externa à ordem jurídica, e autônoma em relação às intenções e finalidades que determinaram a positivação da norma, ou que podem servir de parâmetro para o exercício lícito de posições jurídicas ou para a aplicação da lei ${ }^{54}$. Esse sentido dirige-se aos usos e às práticas econômicas e sociais, e ainda aos interesses que, conforme o caso, podem ilicitamente manipular e distorcer as regras jurídicas e contratuais, ou apenas lhes emprestar um significado diferente do que as fez serem estatuídas, sem chegar a caracterizar ato ilícito ${ }^{55}$. Por essa ótica, nota-se que o pacto comissório: (a) era licitamente praticado em Roma antes de sua proibição por ato do Imperador Constantino, como adiante se verá (item 4.1); (b) pode ser licitamente praticado, hoje, na França, por exemplo, onde não mais vige a sua proibição; e (c) conquanto ilícito, não deixa de ser praticado, mesmo no Brasil, como demonstram os julgados analisados no capítulo 5 desta tese. Considerando as práticas econômicas e sociais efetivas e, abstração feita à sua licitude ou ilicitude em determinado tempo e lugar, é perfeitamente possível, sob a referida perspectiva externa, cogitar de uma função exercida pelo pacto comissório, a

\footnotetext{
${ }^{52}$ Para dois exemplos emblemáticos de raciocínio jurídico desenvolvido em torno desse sentido da função, cf. F.K. COMPARATO. Funções e disfunções do resgate acionário. In: Direito empresarial. Estudos e pareceres. São Paulo, Saraiva, 1990. p. 120-130; e J.L. CORRÊA DE OLIVEIRA. A dupla crise da pessoa jurídica. São Paulo, Saraiva, 1979. p. 259-264.

${ }^{53}$ K. RENNER. The institutions of private law and their social functions. Trad. Agnes Schwarzchild. London, Routledge \& Kegan Paul, 1949.

${ }^{54}$ Sobre a perspectiva interna e a perspectiva externa, no raciocínio jurídico, cf. o capítulo VII (Formalism and rule-scepticism) de H.L.A. HART. The concept of law. 2nd. ed. Oxford, Oxford University Press, 1997. p. 124-154.

${ }^{55}$ Esse último é o caso do chamado negócio jurídico indireto, cf. T. ASCARELLI. Negócio jurídico indireto. Lisboa, Jornal do Foro, 1965; e O. CARVALHO. Negócio jurídico indirecto (teoria geral). In: Escritos. Páginas de direito. Coimbra, Almedina, 1998. p. 35-162.
} 
partir dos interesses concretos de devedores e credores em relação a débitos amparados por garantias.

Nesse contexto, a prática disseminada dos negócios jurídicos de crédito e, a crédito, - isto é, de todos aqueles em que há intervalo de tempo entre prestação e contraprestação - corresponde a um dos aspectos mais relevantes não só das modernas economias de mercado, mas dos sistemas econômicos em geral, desde os tempos mais primitivos ${ }^{56}$. A difusão de tais negócios promove uma "desmaterialização da atividade econômica", na qual viceja o crédito como "bem econômico ideal" ${ }^{57}$. Diante dessa expansão, as técnicas de proteção contra os riscos

56 D. GRAEBER. Debt: the first 5.000 years. New York, Melville House Publishing, 2011 (Kindle Edition - Capítulo 2); e também a obra clássica de M. MAUSS. The gift: forms and functions of exchange in archaic societies. Trad. Ian Cunnison. Mansfield Centre, Martino Publishing, 2011. GRAEBER demonstra que é equivocada, e sem apoio na realidade, a narrativa - frequente entre os economistas - segundo a qual o primeiro estágio das relações econômicas, dentro de determinada comunidade, seria a permuta de bens e serviços, ao qual se seguiria, em um segundo momento, a introdução da moeda como medida de valor e meio de pagamento dotado de poder liberatório, ficando para uma terceira fase a elaboração de um sistema de créditos e débitos. Para um exemplo de como esse é, realmente, o discurso corrente entre os economistas, cf. J.A.B. RIZZIERI. Introdução à economia. In: Manual de economia (organizado pelos Professores do Departamento de Economia da Faculdade $\overline{d e}$ Economia e Administração da Universidade de São Paulo - Diva Benevides Pinho e Marco Antonio Sandoval de Vasconcellos). 2a edição. São Paulo, Saraiva, 1996. p. 25-26; o exemplo dado por GRAEBER é a própria obra de Adam Smith. Nas relações econômicas entre integrantes de uma mesma comunidade, as evidências históricas e antropológicas existentes, desde as pedras mesopotâmicas, apontam para uma sucessão precisamente inversa dos referidos estágios. Segundo essas evidências, a origem primeira das relações econômicas, dentro de uma comunidade, está na prática do favor, que a partir da noção de reciprocidade e da obrigação de retribuí-lo, gera, antes de tudo, o sentido da dívida e do correspondente crédito. Segundo os registros históricos, a moeda aparece como uma espécie de "régua", isto é, como um meio de medir a extensão do favor e da correspondente obrigação de retribuição do favor. A permuta é o terceiro estágio do desenvolvimento do sistema, sendo praticada para adimplemento das obrigações de retribuição. Desde sempre, portanto, apenas uma pequena parte das operações econômicas é efetivamente instrumentalizada por moeda. Mesmo antes da organização dos sistemas monetário e bancário, o chamado "meio circulante" (seja sob a forma de sal, de bois, ou metal cunhado) sempre foi insuficiente para instrumentalizar todas as operações econômicas existentes nas comunidades. Isso sublinha o caráter primevo e onipresente das dívidas e dos correspondentes créditos nas comunidades humanas. O modelo da permuta como primeira base das operações econômicas (que GRAEBER, com algum exagero, chama de "mito da permuta" - myth of the barter) teve lugar na origem das trocas econômicas entre estranhos, isto é, entre pessoas e grupos estrangeiros entre si, sem relações cotidianas de convívio e, por força desse convívio, de cooperação. Ilustra essa circunstância a citação que E. BETTI faz do relato de Heródoto sobre o comércio de ouro entre navegadores cartagineses e populações selvagens das costas africadas do Atlântico, a propósito de explicar o caráter universal e imanente da autonomia privada; ainda segundo E. BETTI esse relato coincide com aquele de um navegador veneziano do sec. XV, Alvise da Cá Mosto. Teoria geral do negócio jurídico. t. I. p. 89-90

57 F.K. COMPARATO. O seguro de crédito. p. 9-12 Ainda sobre as correlações entre moeda, desmaterialização e crédito, cf. J.T. DE ChiARA. Moeda e ordem jurídica. São Paulo, Tese de doutorado apresentada à Faculdade de Direito da Universidade de São Paulo, 1986. p. 80-85. 
de crédito, dentre as quais se incluem as garantias, exercem um papel igualmente crucial $^{58}$.

A referência a garantias, no parágrafo anterior, é feita no sentido mais abrangente possível, de modo a compreender todo o conjunto de instituições, institutos e normas jurídicas que fazem funcionar o que um importante autor denomina de "garantia financeira dos direitos de crédito" $"$. Esse conjunto inclui a responsabilidade patrimonial (art. 391 do Código Civil e 591 do Código de Processo Civil - Lei n. ${ }^{\circ}$ 5.869, de 11 de janeiro de 1973), o processo de execução (todo Livro II do Código de Processo Civil), as ordens de preferência entre os credores (art. 955 do Código Civil, art. 796 do Código de Processo Civil e artigos 83 a 93 da Lei n. 11.101, de 9 de fevereiro de 2005, de ora em diante citada como "Lei de Falências"), a propriedade fiduciária (art. 1.361 a 1.368-A do Código Civil), os negócios fiduciários, as garantias reais (penhor, hipoteca e anticrese), os privilégios gerais e especiais (art. 961 a 964 do Código Civil), e os processos que envolvem concurso de credores de forma geral, incluindo a recuperação, judicial e extrajudicial, a falência e a insolvência civil (esta última disciplinada no art. 748 e seguintes do Código de Processo Civil). Como elemento desse conjunto organizado de normas, se o pacto comissório, por hipótese, fosse lícito, ele desempenharia ao menos duas funções imediatas, em benefício da referida garantia financeira dos direitos de crédito.

A primeira consistiria em eliminar, para o credor, certos riscos relacionados à excussão da garantia. Se o inadimplemento - ispo facto - transfere ao credor a propriedade do bem gravado, o pacto comissório funcionaria como um verdadeiro atalho para a satisfação da obrigação, tornando desnecessário o recurso aos meios judiciais e extrajudiciais de execução do crédito, mediante a identificação, penhora, avaliação e expropriação do objeto da garantia. A expropriação e a transferência da propriedade do bem ao credor ocorreriam pelo tão só advento da mora, poupando ao credor todo o tempo e todos os custos inerentes ao processo judicial ou extrajudicial de execução do crédito. Se fosse lícita a contratação do pacto comissório, bastaria ao credor, diante do inadimplemento do devedor, invocar a

\footnotetext{
${ }^{58}$ F.K. COMPARATO. O seguro de crédito. p. 10-11.

59 J.L. BUlhões PEDREIRA. Finanças e demonstrações financeira das companhias (conceitos fundamentais). $2^{a}$ edição. Rio de Janeiro, Forense, 1989. p. 137-161.
} 
cláusula para se legitimar à propositura de ações inerentes à condição de proprietário do bem dado em garantia, e não de mero credor da obrigação garantida.

A segunda função de um pacto comissório hipoteticamente lícito seria a de eliminar riscos relacionados à insolvência do devedor e, por consequência, ao concurso de credores, nas figuras dos institutos da recuperação judicial e extrajudicial, da falência e da insolvência civil. Se o devedor, pela mera superveniência do inadimplemento, torna-se proprietário do bem, isso significa que esse mesmo bem deixa de integrar o patrimônio do devedor e, portanto, de servir como parte da garantia geral que ele representa para a coletividade dos demais credores. Assumindo, sempre por hipótese, a condição de proprietário do bem antes dado em garantia, o credor poderia se utilizar, em caso de falência, do chamado pedido de restituição, previsto no art. 85 da Lei de Falências. Como simples credor amparado por garantia real, deverá ele aguardar e se submeter às injunções do processo de realização dos ativos da massa, podendo ter seus interesses preteridos (i) por titulares de créditos trabalhistas ou decorrentes de acidentes de trabalho; (ii) por outros credores que tenham a lhes proteger os próprios pedidos de restituição; ou (iii) por titulares dos chamados créditos extraconcursais, identificados nos artigos 67 e 84 da Lei de Falências. O pagamento dessas três categorias de credores precede ao dos demais credores da massa indicados no art. 83 do mesmo diploma, dentre os quais se incluem os credores titulares de garantia real. A situação é muito semelhante na insolvência civil, com a diferença de que, nessa modalidade de concurso de credores, também o fisco é atendido com prioridade em relação aos titulares de garantias reais. O tema será analisado em maiores detalhes no item 4.5.

Ao menos em tese, o pacto comissório representaria assim uma garantia juridicamente infalível, que se realizaria pelo tão só advento da mora ou inadimplemento, sem processo de execução. Ela operaria mediante uma transferência automática da propriedade do bem para o credor, sem concorrência ou interferência dos demais credores. O credor teria, dessa forma, imunidade contra os direitos dos demais credores, por mais privilegiados que sejam. Caso pudesse passar ao plano da eficácia, o pacto comissório resultaria na atribuição ao credor de um poder formativo, cujos efeitos próprios se achariam suspensos por condição. Esses efeitos 
seriam extintivos da titularidade do devedor, e geradores da titularidade do credor sobre o bem ou direito considerado.

\subsection{Estrutura do pacto comissório.}

Este capítulo 2 propõe-se, também, a dissecar dogmaticamente o pacto comissório. Para tanto, a fattispecie será estudada mediante comparação com outras que podem ser consideradas vizinhas ou semelhantes, como é o caso (a) das obrigações alternativas; (b) da compra e venda; (c) da dação em pagamento; (d) da cláusula penal; (e) da alienação em garantia; (f) da realização da garantia; e (g) da retrovenda.

\subsubsection{Em que consiste o pacto comissório?}

De acordo com os artigos 1.365 e 1.428 do Código Civil, o pacto comissório pressupõe: (a) a existência de uma obrigação não vencida, isto é, de uma relação jurídica obrigacional, de caráter principal, ainda não inflamada pela nota da exigibilidade; (b) a constituição, em favor do credor dessa obrigação, de garantia correspondente a propriedade fiduciária (art. 1.365), hipoteca, penhor ou anticrese (art. 1.428), ou seja, de uma relação jurídica de direito das coisas, de caráter acessório; e (c) a estipulação da cláusula propriamente dita, que atribui automaticamente ao credor, pela tão só ausência de pagamento pontual, o poder, em sentido amplo, de "ficar com" o bem alienado fiduciariamente, ou dado em penhor, hipoteca ou anticrese.

Vê-se que o Código Civil - e o mesmo já ocorria com o art. 765 do Código de 1916 - não se vale termos técnicos ou precisos para se referir à posição jurídica que o pacto comissório pretende atribuir ao credor, como consequência da impontualidade do devedor. Que significa, nesses dispositivos legais, "ficar com"? Significa possuir? Ser proprietário? Ambos ou nenhum?

Há engenho nessa vagueza. É evidente que "ficar com" não significa a transferência ao credor de posse - mediata, no caso - do bem objeto de garantia. Por 
força do direito de sequela que integra as posições jurídicas complexas de direito das coisas, o proprietário fiduciário e o credor titular de penhor, hipoteca ou anticrese já detém, em caso de inadimplemento do devedor, direito à posse do bem. $\mathrm{O}$ art. 1.433, I, do Código Civil é explícito ao atribuir ao credor pignoratício o direito à posse da coisa empenhada. Um pacto comissório que simplesmente desse ao credor tal direito à posse do bem, em caso de inadimplemento do devedor, seria redundante com a disciplina legal aplicável à espécie, e não estaria apto a desempenhar a função esperada dessa cláusula, conforme descrita no item 2.2. Para que essa função seja cumprida, é preciso atribuir à locução "ficar com" o sentido de uma pretendida transferência também de propriedade, mas não apenas de propriedade.

O conceito que melhor exprime a abrangência da hipótese legal, nesse ponto, é aquele de titularidade, ou de propriedade em sentido amplíssimo ${ }^{60}$. "Ficar com" significa uma autorização para atribuir a si a pertinência da posição jurídica patrimonial objeto da garantia, que pode consistir em direito de crédito, conforme se vê no penhor de direitos de crédito (artigos 1.451 a 1.460 do Código Civil), em qualquer direito real limitado de gozo, ou ainda na propriedade em sentido estrito, entendida como domínio. Em princípio, é possível constituir hipoteca sobre direito real de usufruto, sobre direito real de superfície, ou sobre direito real de uso. Em todos esses últimos casos, por se tratar de hipoteca, incidirá o art. 1.428 do Código Civil, e estará igualmente proibido o pacto comissório". Assim, "ficar com" significa tornar-se proprietário em senso amplíssimo, isto é, no sentido constitucional de se tornar titular de patrimonialidade ${ }^{62}$.

Em seu conteúdo, essa titularidade que recai sobre patrimonialidade apresenta quatro feições distintivas. A primeiro delas é o caráter imediato ou exclusivo da pretensão que lhe é inerente; o poder (lato sensu) ínsito à posição jurídica dirige-se de modo imediato (a) à prestação, no caso dos direitos de crédito, ou (b) ao bem objeto de direitos reais, no caso destes últimos, excluindo, do exercício

${ }^{60}$ R.D.F. VANZELLA. Numerus clausus dos direitos reais e autonomia nos contratos de disposição. Tese de doutoramento apresentada à Faculdade de Direito da Universidade de São Paulo, São Paulo, 2009. p. 65-76.

${ }^{61}$ Não se passa o mesmo em relação ao penhor de títulos de crédito e direitos de crédito, como se verá no capítulo 4.

62 F.C. Pontes de MiRAndA. Comentários à Constituição de 1967. t. V. São Paulo, Revista dos Tribunais, 1968. p. 364-369. 
desse poder, em qualquer dos dois casos, todos os demais indivíduos. A segunda nota distintiva é a oponibilidade a sujeitos passivos totais, que protege tanto o titular do crédito quanto o titular do direito real de interferências de quaisquer outros que não sejam o próprio titular. Todos devem abster-se de interferir indevidamente não apenas nos direitos absolutos de titularidade de terceiros, mas também nos direitos de crédito de terceiros. Não é porque apenas o devedor tem a obrigação principal de prestar que terceiros terão autorização para causar danos a direitos de crédito. $\mathrm{O}$ princípio da incolumidade das esferas jurídicas protege tanto os direitos ditos absolutos como também os direitos ditos relativos. Em terceiro lugar, o conceito de titularidade implica a imunidade contra a disposição, do crédito ou do direito real, por terceiros que não o titular. Em quarto e último lugar, ser titular significa também ter imunidade contra execuções, individuais e coletivas (concurso civil de credores ou falência) ${ }^{63}$. Esses quatro elementos, e em especial os dois últimos - imunidade contra disposições e execuções - não por acaso se amoldam com justeza à pretendida função do pacto comissório, descrita no item 2.2.

Surge, no entanto, uma questão estrutural, adicional e relevante, ao se pensar os efeitos jurídicos hipoteticamente lícitos do pacto comissório. No direito brasileiro, o mero consenso, refletido na celebração de pacto comissório, é insuscetível de operar a transferência da propriedade (art. 1.267 do Código Civil). O ato apto a esse fim é a tradição do bem, no caso das coisas móveis, ou o registro do acordo de transmissão na matrícula imobiliária, no caso dos bens imóveis ${ }^{64}$. No caso da constituição de garantia real, acompanhada da celebração de pacto comissório, em que ato estaria plasmada a tradição ou o registro aptos a promoverem a almejada transferência de propriedade ao credor?

Para que faça sentido proibir o pacto comissório - pois do contrário ele seria estéril, e seria inútil a sua proibição - é preciso concluir que essa tradição se aperfeiçoa no desmembramento da posse, que tem lugar quando da constituição dos direitos reais de garantia ${ }^{65}$, incluindo a propriedade fiduciária (art. 1.361, $\S 2^{\circ}$, do

\footnotetext{
${ }^{63}$ Todo esse parágrafo procura se apoiar nas construções de R.D.F. VANZELLA. Numerus clausus dos direitos reais e autonomia nos contratos de disposição. p. 39-64.

${ }^{64}$ D. Bessone. Direitos reais. p. 166; e L.C. PENTEADO. Direito das coisas. p. 260-261.

${ }^{65}$ Sobre o desmembramento da posse, em particular nos penhores em que a posse permanece com o devedor (penhor rural, industrial, mercantil e de veículos, cf. art. 1.431, parágrafo único, do Código
} 
Código Civil $^{66}$ ). Cuida-se, em síntese, da primeira das hipóteses de tradição previstas no parágrafo único do referido art. 1.267 do Código Civil. É dela que o pacto comissório extrai a sua pretendida - ainda que vedada - eficácia no plano do direito das coisas ${ }^{67}$.

Não se exige, por outro lado, para a caracterização da hipótese do pacto comissório, que o bem objeto da garantia seja de titularidade do devedor. Pode-se se tratar de garantia prestada por terceiro e, também nesses casos, incidirão os artigos 1.365 e 1.428 do Código Civil.

Por fim, cabe reiterar que a caracterização do pacto comissório propriamente dito, no direito positivo brasileiro, exige que a sua estipulação seja anterior ao vencimento da obrigação. O pacto pode assim ser tanto coevo à celebração do negócio jurídico que dá origem à relação obrigacional principal, como também posterior a ela (pacto comissório ex intervallo), desde que seja anterior ao vencimento.

Vencida a dívida, e se fazendo exigível a prestação, a lei admite que devedor e credor acordem, licitamente, a dação em pagamento do bem objeto da garantia. É o que se lê nos parágrafos únicos dos referidos artigos 1.365 e 1.428 do Código Civil.

\subsubsection{Pacto comissório e obrigações alternativas.}

A existência (a) de uma obrigação, normalmente pecuniária, somada (b) à sua a pretendida satisfação mediante transferência da titularidade do objeto da garantia poderia induzir o pensamento: (i) para as hipóteses em que se verifica a

Civil), cf. F.C. PONTES DE MIRANDA. Tratado de direito privado. t. XXI. $3^{\text {a }}$ edição. São Paulo, Revista dos Tribunais, 1984. p. 68-69. A disciplina do penhor de veículos tende ao absoluto desuso; é sabido que, nessa seara, são onipresentes as alienações fiduciárias. Nestas últimas também ocorre o mencionado desmembramento da posse.

${ }^{66}$ Cabe a transcrição: " $\$ 2^{\circ}$ - Com a constituição da propriedade fiduciária, dá-se o desdobramento da posse, tornando-se o devedor possuidor direto da coisa".

${ }^{67}$ Por vezes se cogita de um pacto comissório de efeitos meramente obrigacionais, que por ocasião do inadimplemento redundaria na imposição ao devedor da simples obrigação de transferir a propriedade do bem ao credor. Dada a timidez e o parco interesse prático que tal cláusula teria, este trabalho não se ocupará dessa hipótese. 
pluralidade de prestações ${ }^{68}$ e, (ii) estando o adimplemento a cargo do devedor, para a hipótese das obrigações alternativas. O pacto comissório, todavia, não se confunde e, em realidade, distingue-se com clareza das obrigações alternativas, disciplinadas nos artigos 252 a 256 do Código Civil.

Nas obrigações alternativas, estão previstas duas ou mais prestações, mas apenas uma delas comporta exigência pelo credor; é mediante a realização de apenas uma delas que o devedor se libera do vínculo; e a escolha, ou concentração, pode caber ao devedor, ao credor ou a terceiro ${ }^{69}$. As obrigações alternativas: (a) opõem-se, em primeiro lugar, às obrigações ditas cumulativas ou conjuntivas, em que o devedor somente obtém liberação pela realização de todas as prestações previstas; e (b) não se confundem com as chamadas obrigações com faculdade alternativa $^{70}$. Nas obrigações com faculdade alternativa, apenas uma prestação é devida e exigível, mas se faculta ao devedor - exclusivamente ao devedor, sem interferência possível do credor - a possibilidade de realizar uma segunda e outra prestação, para se liberar do vínculo. Não existe, nas referidas obrigações com faculdade alternativa, a indeterminação da prestação que, antes da concentração, caracteriza a figura das obrigações alternativas. Nas obrigações alternativas, ademais, se uma das prestações se torna impossível, subsiste o dever de prestar a outra, ou as outras prestações (art. 253 do Código Civil). Nas obrigações com faculdade alternativa, a impossibilidade da prestação prevista acarreta a extinção da obrigação nos mesmos moldes do que ocorre nas obrigações simples, isto é, sem pluralidade de prestações $^{71}$. A segunda prestação não está ao alcance da pretensão do credor.

Essas circunstâncias indicam que há diversos motivos pelos quais é inviável assimilar o pacto comissório às obrigações alternativas ${ }^{72}$. Nas obrigações alternativas, a escolha ou concentração é necessariamente posterior ao surgimento da

\footnotetext{
${ }^{68}$ A doutrina refere-se ao conjunto dessas hipóteses pela locução obrigação complexa ou composta, ou ainda múltipla, que englobaria as obrigações conjuntivas ou cumulativas, alternativas e com facultas alternativa, cf. W. B. MONTEIRO e C.A.D. MALUF. Curso de direito civil. Direito das obrigações ( $1^{a}$ parte). $35^{\text {a }}$ edição. São Paulo, Saraiva, 2010, p. 131. Para um tratamento mais detalhado do mesmo tema, cf. J.M. ANTUNES VARELLA. Das obrigações em geral. v. I. p. 827-845. Sobre as obrigações alternativas, em particular, cf. F.C. PONTES DE MIRANDA. Tratado de direito privado. t. XXII. $3^{a}$ edição. São Paulo, Revista dos Tribunais, 1984. p.123-150.

${ }^{69}$ F.C. PONTES DE MIRANDA. Tratado de direito privado. t. XXII. p.123.

${ }^{70}$ J.M. ANTUNES VARELLA. Das obrigações em geral. v. I. p. 827.

${ }^{71}$ F.C. PONTES DE MIRANDA. Tratado de direito privado. t. XXII. p.141.

${ }^{72}$ C.M. BiAnCA. Il divieto del patto comissorio. Milano, Giuffré, 1957. p. 108-110.
} 
relação jurídica obrigacional. No pacto comissório, ao contrário, além de ser errôneo pressupor a existência de uma verdadeira e própria escolha, ou concentração, esta surge em regra de modo concomitante com a relação jurídica obrigacional, embora nada impeça que seja posterior (pacto comissório ex intervallo). De todo modo, não há, no pacto comissório, a necessidade de a escolha, ou concentração, ser posterior à formação da relação jurídica obrigacional. Em segundo lugar, nas obrigações alternativas, a concentração é sempre e, por definição, ato voluntário e lícito, ao passo que, no pacto comissório, a suposta escolha implica inadimplemento, isto é, implica a prática de um ilícito. Por fim, aquilo que, em tese, representaria a segunda prestação, no caso do pacto comissório, na realidade é uma consequência jurídica que se processa ispo facto, e não um ato de colaboração espontânea do devedor. Esse adimplemento automático, que seria o efeito do pacto comissório, decididamente não é escolhido, nem apenas pelo credor, nem apenas pelo devedor, nem pode ser escolhido por terceiro; ele é fruto do acordo, entre credor e devedor, que caracteriza o pacto comissório, e da tradição que se opera na constituição da garantia real, via desmembramento de posse, no caso dos bens móveis, ou via registro da escritura pública de constituição da garantia imobiliária, no caso dos bens imóveis.

\subsubsection{Pacto comissório e compra e venda.}

Haveria, embutida no pacto comissório, uma compra e venda do bem objeto de garantia, em que figura o devedor como vendedor, e o credor como comprador $^{73}$ ? Parece evidente que não. Já pela leitura do art. 482 do Código Civil, nota-se que falta, no pacto comissório, o acordo sobre o preço, que é essencial à caracterização da compra e venda.

A isso seria possível objetar que a compra e venda comporta a determinação do preço por terceiro, ou ainda por referência a cotações de mercado, bolsa, índices ou outros parâmetros, "suscetíveis de objetiva determinação" (artigos 486 e 487 do Código Civil). Todavia, a fixação de um procedimento - desatrelado do arbítrio das partes - para a determinação do preço da coisa objeto de garantia, é precisamente o que descaracterizaria o pacto comissório (ilícito) que, nessa

${ }^{73}$ Em suas linhas gerais, a refutação da ideia consta de C. M. BIANCA. Il divieto del patto comissorio. p. 105-107. 
específica hipótese, passaria a se qualificar como pacto marciano ${ }^{74}$ (lícito), ao qual se dará maior atenção no item 4.6.1.

Por outro lado, a extinção do débito, em decorrência de se operar uma hipotética eficácia do pacto comissório, não é capaz de transformar o valor da dívida em autêntico preço ${ }^{75}$. Para que se sustente haver identidade entre compra e venda e pacto comissório, o pagamento do preço, a rigor, deveria estar plasmado no ato que deu origem à dívida amparada por garantia real. Só que esse pagamento, via de regra, é um empréstimo, e não a contrapartida pela transferência da propriedade (em sentido amplo) sobre o bem.

A verdade, ademais, é que há uma clara diferença entre as causas concretas dos dois negócios jurídicos ${ }^{76}$. Quem celebra pacto comissório busca garantir o adimplemento de uma dívida. Por isso, a transferência de titularidade sobre posição jurídica patrimonial, inerente ao pacto comissório, opera a solvência do débito. Se a dívida é paga, tempestivamente, ninguém teve o propósito prático de transferir titularidade de patrimônio, recebendo preço, em contrapartida. Na compra e venda, o que o comprador busca é a propriedade da coisa; e a finalidade comum a ambas as partes é que essa transferência de propriedade se realize, tendo o pagamento do preço como contraprestação ${ }^{77}$.

\subsubsection{Pacto comissório e dação em pagamento.}

Mais tênue - em cotejo com a compra e venda - é a diferenciação entre o pacto comissório e a dação em pagamento. No direito italiano, BIANCA parece não ter grandes dificuldades em distinguir, com convicção, as duas figuras ${ }^{78}$. No

\footnotetext{
${ }^{74}$ Entende-se por pacto marciano aquele segundo o qual o titular da garantia fica autorizado a se apropriar do bem que lhe serve de objeto se essa transferência se der por valor que seja avaliado ou estimado por terceiro independente das partes credora e devedora, avaliação ou estimativa essa que pode ocorrer antes ou após o vencimento da dívida.

${ }^{75}$ C. M. BIANCA. Il divieto del patto comissorio. p. 106

${ }^{76}$ Sobre a ideia de causa concreta, mais abrangente do que a noção de função econômica e social inerente ao tipo contratual, cf. V. RopPo. Il contratto. In: Tratatto di Diritto Privato (a cura di Giovanni Iudica e Paolo Zatti). Milano, Giuffrè, 2001. p. 430-431.

${ }^{77}$ F.C. PONTES DE MIRANDA. Tratado de direito privado. t. XXXIX. $3^{\text {a }}$ edição. São Paulo, Revista dos Tribunais, 1984. p. 11.

${ }^{78}$ C. M. BIANCA. Il divieto del patto comissorio. p. 107-108.
} 
direito brasileiro, porém, a redação dos parágrafos únicos do art. 1.365 e do art. 1.428 do Código Civil, parecem tornar essa distinção, no mínimo, menos nítida.

Ao autorizar que, após o vencimento, o devedor dê ao credor a coisa objeto da garantia real ou fiduciária, é a própria lei que parece ler - no pacto comissório - um acordo para dação em pagamento, ao qual se apõe condição suspensiva, consistente no inadimplemento da dívida. Pelo pacto comissório, em outras palavras, o devedor ofereceria, e o credor consentiria, em "receber prestação diversa da que lhe é devida" (art. 356 do Código Civil), o que se estipularia de modo condicionado à impontualidade do devedor no pagamento da dívida.

É controverso, na Itália, o caráter real ou obrigacional da dação em pagamento $^{79}$. No Brasil, PONTES DE MiRANDA não hesita em qualifica-la como "negócio jurídico bilateral de alienação" ou "contrato real"; esse autor destaca ainda que, para haver dação em pagamento, a eficácia deve ser "posterior ao fato jurídico de que resulta a dívida" ${ }^{80}$. Fala-se de uma eficácia posterior, e não de um acordo posterior, pelo que não fica afastada a sugerida identidade de estrutura entre o pacto comissório e uma dação em pagamento condicionada ao inadimplemento. O mesmo PONTES DE MIRANDA também parece sustentar que a diferença básica entre o pacto comissório e a dação em pagamento estaria em haver ou não dívida vencida ${ }^{81}$. Ao enumerar "figuras jurídicas parecidas" com a dação em pagamento, o mesmo autor faz referência ao dispositivo legal que veda o pacto comissório, justamente para dizer que, em se passando o negócio após o vencimento do débito, a dação em soluto vale e é eficaz ${ }^{82}$. Fica com isso estabelecida a percepção de que a vedação do pacto comissório é dirigida a uma conduta que, em substância, corresponde a uma dação em pagamento sob condição suspensiva, de dívida não vencida, cujo objeto é o bem dado em garantia.

Disso resulta que, no direito brasileiro, há notável proximidade entre a dação em pagamento e o pacto comissório. Apesar dessa semelhança, é possível

\footnotetext{
${ }^{79}$ C. M. BIANCA. Il divieto del patto comissorio. p. 108, nota 7.

${ }^{80}$ F.C. PONTES DE MIRANDA. Tratado de direito privado. t. XXV. $3^{\text {a }}$ edição. São Paulo, Revista dos Tribunais, 1984. p. 3-6.

${ }^{81}$ F.C. PONTES DE MIRANDA. Tratado de direito privado. t. XXV. p. 3-6.

${ }^{82}$ F.C. PONTES DE MIRANDA. Tratado de direito privado. t. XXV. p. 16.
} 
apontar duas circunstâncias capazes de extremar as duas figuras. A primeira reside na citada circunstância de estar ou não vencida a dívida. Nesse aspecto, a dação em pagamento, propriamente dita, é lícita tanto antes como após o vencimento da obrigação. Já o pacto comissório, vedado pela lei, é aquele em que o acordo sobre a transferência, do devedor para o credor, de posição jurídica patrimonial para adimplemento de dívida ocorre necessariamente antes do vencimento. Depois do vencimento, as figuras parecem convergir, como sugerem os referidos parágrafos únicos, dos artigos 1.365 e 1.428 do Código Civil. A segunda diferença diz respeito à existência prévia de ônus sobre o bem em que recai a dação em pagamento. $\mathrm{Na}$ dação em pagamento propriamente dita - que é lícita - o bem ou direito sobre o qual recai a oferta do devedor, e o consentimento do credor, estão livres e desembaraçados, e não há vinculação anterior com o adimplemento do débito. Tratase do "aliud pro alio", conforme a dicção das fontes romanas ${ }^{83}$. No pacto comissório, é decisiva a existência do ônus prévio, estabelecido pela garantia real (penhor, hipoteca, anticrese ou propriedade fiduciária). O bem ou direito sobre o qual recai o pacto comissório não é um autêntico "aliud" em relação à prestação principal, sobre o qual não se cogitou quando do fato que originou o débito. Ao contrário, tal bem ou direito era conhecido, identificado, tendo credor e devedor lhe atribuído, de comum acordo, a função de garantir o pagamento da dívida.

\subsubsection{Pacto comissório e cláusula penal.}

Outra distinção a ser feita é aquela que extrema o pacto comissório da cláusula penal $^{84}$. Se o pacto comissório é uma resposta pré-estabelecida à mora ou inadimplemento do devedor, teria ele o significado de uma cláusula penal, conforme disciplinada nos artigos 408 a 406 do Código Civil? Embora o mais comum seja a fixação da pena convencional em dinheiro, nada impede que ela corresponda à obrigação de entregar uma coisa ${ }^{85}$. Existe, ainda, entre as duas figuras, certa afinidade funcional. A cláusula penal visa tanto a estimular o devedor a cumprir espontaneamente a obrigação (objetivo comum tanto à cláusula penal compensatória como àquela apenas punitiva), como também a ressarcir o credor das perdas e danos

${ }^{83}$ F.C. PONTES DE MIRANDA. Tratado de direito privado. t. XXV. p. 5.

${ }^{84}$ C. M. BIANCA. Il divieto del patto comissorio. p. 110-114.

${ }^{85}$ W. B. Monteiro e C.A.D. MALuf. Curso de direito civil. p. 387; e J.M. Antunes VARELla. Direito das obrigações. v. 2. Rio de Janeiro, Forense, 1979. p. 169-170. 
decorrentes da mora ou inadimplemento (objetivo restrito à modalidade compensatória) $^{86}$. A perda da propriedade sobre o bem objeto da garantia, no caso do pacto comissório, parece exercer papel análogo, na criação de consequências adversas para o devedor inadimplente e na indenização do credor. Além disso, porém, não se pode avançar.

A diferença capital entre o pacto comissório e a cláusula penal consiste na eficácia desta última, que está confinada no direito das obrigações, sem incursões no campo dos direitos reais ${ }^{87}$. A eficácia real está no âmago do pacto comissório, e da função que se espera que ele desempenhe, consoante explicado no item 2.2. Além disso, desponta no pacto comissório um sentido bastante específico de garantia, relacionado à vinculação de um bem ou direito integrante do patrimônio do devedor à satisfação da dívida. Embora a cláusula penal não deixe de ser uma espécie de reforço da relação jurídica obrigacional, não se trata de garantia nesse sentido estrito ${ }^{88}$.

Ademais, o pacto comissório dirige-se contra o inadimplemento de uma obrigação principal, enquanto a cláusula penal pode versar também sobre a mora ou inadimplemento de obrigações acessórias ou especiais (art. 409 do Código Civil). A possibilidade de cumular a exigência da cláusula penal e da obrigação principal, prevista no art. 411 do Código Civil, também é inconcebível em relação ao pacto comissório. Do contrário, haveria enriquecimento injustificado do credor. A redução de valor, decorrente de cumprimento parcial, ou do seu caráter excessivo (art. 413 do Código Civil), do mesmo modo, é igualmente incompatível com o que se espera de um pacto comissório.

\subsubsection{Pacto comissório e alienação em garantia.}

Já se notou que o pacto comissório tem causa concreta distinta e inconfundível com a causa concreta da compra e venda (item 2.3.3). Não obstante

\footnotetext{
${ }^{86}$ W. B. Monteiro e C.A.D. Maluf. Curso de direito civil. p. 388-389; e J.M. Antunes VARELla. Direito das obrigações. v. 2. p. 170-172. Sobre a função da cláusula penal, cf. também M. Continentino. Da cláusula penal no direito brasileiro. São Paulo, Saraiva, 1926. p. 32-36.

${ }^{87}$ C. M. BIANCA. Il divieto del patto comissorio. p. 111.

${ }^{88}$ C. M. BIANCA. Il divieto del patto comissorio. p. 113-114.
} 
essa circunstância, BIANCA não hesita em situar o pacto comissório no terreno das alienações em garantia, entre as quais se destaca, justamente, a compra e venda com finalidade de garantia $^{89}$; tal aproximação leva o raciocínio desse autor à figura dos negócios fiduciários ${ }^{90}$. Para BIANCA, o pacto comissório corresponde a uma alienação em garantia, sob condição suspensiva, consistindo esta no inadimplemento ${ }^{91}$.

Essa equiparação do pacto comissório à alienação em garantia condicionada apresenta problemas. O mais decisivo deles refere-se à suposição inerente ao argumento de BIANCA - de que a transferência de propriedade (em sentido amplo) que se opera por força da deflagração do pacto comissório seria, ela mesma, uma transferência em garantia; como se o pacto comissório fosse uma espécie de garantia de segundo grau, que se sobreporia ao penhor, à hipoteca e à anticrese.

Não existe nenhuma circunstância, presente na lei ou na prática contratual, que sugira existir - na transferência de propriedade inerente à eficácia do pacto comissório - um caráter fiduciário. Além de implicar uma redundância, esse argumento mostra-se também incompatível com o direito positivo brasileiro, em que o pacto comissório é expressamente vedado inclusive no caso da propriedade fiduciária (art. 1.365 do Código Civil). Se já houve, quando da celebração do negócio jurídico que originou a dívida, uma transferência de propriedade em garantia (fiduciária, portanto), é um contrassenso supor que o pacto comissório, nesse contexto, possa representar uma nova alienação em garantia. Seria o mesmo, nas palavras de PONTES DE MIRANDA, que proibir o proprietário (fiduciário) de se tornar

\footnotetext{
${ }^{89}$ C. M. BIANCA. Il divieto del patto comissorio. p. 116-128.

${ }^{90}$ A bibliografia sobre os negócios fiduciários é vasta, e eles constituem, nesta tese, um tema lateral; não se pretende, por isso, realizar tratativa extensa ou pormenorizada sobre esse assunto, mas apenas colher os elementos que se mostram úteis à análise do pacto comissório. Sobre os negócios fiduciários, no direito brasileiro: F.C. PONTES DE MIRANDA. Tratado de direito privado. t. III. $3^{\mathrm{a}}$ edição. Rio de Janeiro, Borsói, 1970. p. 115-128; J.C. MOREIRA ALVES. Da alienação fiduciária em garantia. $2^{a}$ edição. São Paulo, Saraiva, 1979; e A retrovenda. $2^{a}$ edição. São Paulo, Revista dos Tribunais, 1987. p. 5-24; P. RESTIFFE NETO e P.S. RESTIFFE. Garantia fiduciária. $3^{a}$ edição. São Paulo, Revista dos Tribunais, 2000. p. 21-47; e M.N. CHALHUB. Negócio fiduciário. Alienação fiduciária. Cessão fiduciária. Securitização. $3^{\text {a }}$ edição. Rio de Janeiro, Renovar, 2006.

${ }^{91}$ C. M. BIANCA. Il divieto del patto comissorio. p. 136.
} 
o que ele já é é $^{92}$ Logo, essa por assim dizer segunda transferência de propriedade não pode ter a mesma estrutura da primeira, isto é, não pode ser tida como fiduciária.

Essa análise e, principalmente, o contraste entre o raciocínio de BIANCA e as disposições legais vigentes no Brasil, demonstram que o significado último do pacto comissório, no direito brasileiro, é o de realização ou excussão da garantia, e consequente satisfação do crédito ${ }^{93}$. É essa, segundo defende esta tese, a estrutura do pacto comissório no direito brasileiro.

\subsubsection{Pacto comissório e realização da garantia.}

A deflagração dos efeitos do pacto comissório - não é demais repetir, sob a hipotética premissa de sua licitude - realiza, ou excute, a garantia, satisfazendo e extinguindo a relação jurídica obrigacional. Em termos dogmáticos, o pacto comissório representa uma forma de realização da garantia. $\mathrm{Na}$ elucidativa abordagem de PUGLiATTI, a execução (no sentido de obtenção do cumprimento), voluntária ou coativa, dos direitos de crédito apresenta sempre a mesma estrutura, pois sua finalidade e seus efeitos últimos coincidem: desembocam na satisfação do credor e na extinção da relação obrigacional ${ }^{94}$. Essa consecução do cumprimento pode contar com a colaboração espontânea do devedor, seja pela prestação originalmente devida $(i d)$, seja pela realização de outra prestação, aceita pelo credor $($ aliud). Do mesmo modo, também na execução coativa, posta em marcha a despeito da iniciativa ou da colaboração do devedor, a obtenção do cumprimento pode incidir sobre a prestação originalmente devida $(i d)$ ou sobre outra prestação que se perfaça a débito do patrimônio do devedor (aliud $)^{95}$.

Pela ótica da relação jurídica de direito privado, o que se passa é a subentrada do credor na posição jurídica de titular do bem ou direito objeto de garantia, posição essa antes ocupada pelo devedor. A causa dessa subentrada é a

92 F.C. PONTES DE MIRANDA. Tratado de direito privado. t. XXI. $3^{\text {a }}$ edição. São Paulo, Revista dos Tribunais, 1984. p. 333.

93 Ainda segundo M. BIANCA (Il divieto del patto comissorio. p. 137), essa seria a tese defendida pelo autor alemão RAAPE. Verfallklausel bei Pfand und Sicherung-Übereignung. Berlin, F. Vahlen, 1913.

${ }^{94}$ S. PUGLIATTI. Esecuzione forzata e diritto sostanziale. Ristampe della Scuola in perfezionamento in diritto civile dell’Univesità di Camerino. Camerino, Edizioni Scientifiche Italiane. 1978. p. 11-16.

${ }^{95}$ S. PUGLiATTI. Esecuzione forzata e diritto sostanziale. p. 21. 
causa solvendi. Opera-se uma aquisição derivada dessa posição jurídica ativa, que não confunde com uma sucessão em sentido técnico, nem com a sub-rogação coativa; a sucessão em sentido estrito e técnico, realmente, apenas tem lugar por força de lei (e não como resultado de negócio jurídico), e a sub-rogação coativa qualifica-se como aquisição originária ${ }^{96}$. Embora até se presuma existir interesse do credor nesse sentido, é fato que uma aquisição decorrente da deflagração de efeitos de pacto comissório - hipoteticamente considerada - não poderia ser equiparada à aquisição originária que tem lugar por força de arrematação feita por terceiro no curso de um processo de execução. Em uma imaginada situação em que o pacto comissório fosse lícito, o credor haveria para si a titularidade do bem ou direito de modo derivado, isto é, teria o direito do devedor sobre esse mesmo bem ou direito como fundamento e origem do seu direito, que estará sujeito, portanto, às mesmas vicissitudes que porventura acometam o direito-base ${ }^{97}$.

Na jurisprudência do STJ, está assentado que a verdadeira e própria aquisição originária - por força da qual o adquirente está imune às vicissitudes do direito-base - é aquela realizada por terceiros, e não pelo credor exequente. Se há leilão ou hasta, com aquisição do bem por terceiro, a aquisição é originária. Mas se o que ocorre é mera adjudicação pelo exequente, o tribunal entende que a aquisição é derivada e que o adquirente responde por eventuais ônus ou gravames do direito-base (v.g. tributos não pagos $)^{98}$.

\footnotetext{
${ }^{96}$ Sobre esses temas, cf. S. PUGLIATTI. Esecuzione forzata e diritto sostanziale. p. 114-116 e 125; E. BETTI. Teoria geral do negócio jurídico. t. I. Trad. Fernando de Miranda. Coimbra, Coimbra Editora, 1969. p. 49-70; F.K. COMPARATO. Sucessões empresariais. In: Revista dos Tribunais, v. 747, p. 793799. São Paulo (jan. 1998); e W. MORAES. Teoria geral e sucessão legítima (programa de direito das sucessões). São Paulo, Revista dos Tribunais, 1980. p. 1-3.

${ }^{97}$ A expressão direito-base, nesse contexto, é utilizada por E. BETTI. Teoria geral do negócio jurídico. t. I. p. 60. Sobre as noções de aquisição originária e aquisição derivada, na doutrina brasileira, cf. F. AMARAL. Direito civil. Introdução. $4^{\text {a }}$ edição. Rio de Janeiro, Renovar, 2002. p. 169-170.

${ }^{98}$ Cf. Recurso Especial n. ${ }^{\circ}$ 905.208/SP, Terceira Turma, Rel. Min. Humberto Gomes de Barros, j. 18.10.2007; e Recurso Especial n. ${ }^{\circ}$ 1.179.056/MG, Segunda Turma, Rel. Min. Humberto Martins, j. 07.10.2010; ambos consultados em www.stj.gov.br; acesso em 16.12.2012. A ementa dessa última decisão é esclarecedora: "I - Discute-se nos autos se o credor-exequente (adjudicante) está dispensado do pagamento dos tributos que recaem sobre o imóvel, anteriores à adjudicação. 2 Arrematação e adjudicação são situações distintas, não podendo a analogia ser aplicada na forma pretendida pelo acórdão recorrido, pois a adjudicação pelo credor com dispensa de depósito do preço não pode ser comparada a arremate por terceiro. 3 - A arrematação em hasta pública extingue o ônus do imóvel arrematado, que passa ao arrematante livre e desembaraçado do tributo ou responsabilidade, sendo, portanto, considerada aquisição originária, de modo que os débitos tributários anteriores à arrematação sub-rogam-se no preço da hasta. (...) 4 -O adquirente só deixa de ter responsabilidade pelo pagamento de débitos anteriores que recaiam sobre o bem se ocorreu, efetivamente, depósito do preço, que se tornará a garantia dos demais credores. De molde que o
} 


\subsubsection{Pacto comissório e retrovenda.}

É vetusta, bastante conhecida e debatida, a utilização da compra e venda com pacto de retrovenda como negócio jurídico indireto, destinado a atingir efeitos práticos equivalentes ao de mútuo acompanhado de transmissão de propriedade em garantia ${ }^{99}$. É frequente, ademais, a afirmação - contestada por MoREIRA ALves no trecho citado - de que esse arranjo negocial em verdade representaria negócio jurídico simulado, ou fraudulento, tendente a contornar, precisamente, a vedação do pacto comissório ${ }^{100}$. De acordo com Alvino LimA, a diferença estrutural entre o pacto comissório e a compra e venda com pacto de retrovenda está na circunstância de que, na retrovenda, a transferência da propriedade é antecipada; ocorre antes do vencimento; e o inadimplemento apenas torna irreversível a transferência anteriormente realizada ${ }^{101}$. No caso do pacto comissório, essa mesma transferência não precede o inadimplemento, mas fica condicionada, de modo suspensivo, à sua ocorrência. Em síntese, a semelhança da retrovenda com o pacto comissório não é exatamente estrutural, mas funcional. As correlações entre o pacto comissório e a retrovenda foram bastante discutidas pelos tribunais brasileiros. Não cabe aqui tomar partido nessa polêmica. $\mathrm{O}$ tema voltará à tona no capítulo 5 .

crédito fiscal perquirido pelo fisco é abatido do pagamento, quando da praça, por isso que, encerrada a arrematação, não se pode imputar ao adquirente qualquer encargo ou responsabilidade. 5- Por sua vez, havendo a adjudicação do imóvel, cabe ao adquirente (credor) o pagamento dos tributos incidentes sobre o bem adjudicado, eis que, ao contrário da arrematação em hasta pública, não possui o efeito de expurgar os ônus obrigacionais que recaem sobre o bem.".

99 J.C. MoreIRA Alves. A retrovenda. p. 5-24; e M.M. SERPA LOPES. Curso de direito civil. v. III (fontes das obrigações: contratos). $4^{\mathrm{a}}$ edição. Atualizada por José Serpa Santa Maria. Rio de Janeiro, Freitas Bastos, 1991. p. 308-311.

${ }^{100}$ Em sentido contrário a J.C. MOREIRA ALVES, isto é, defendendo que a retrovenda implica negócio fraudulento, cf. Alvino LimA. A fraude no direito civil. São Paulo, Saraiva, 1965. p. 302-321. Também sobre o tema, cf. o sintético e preciso parecer de E.T. LIEBMAN. Penhor. Retrovenda. In: Contratos em espécie: atribuição patrimonial e garantia (organizadores Gustavo Tepedino e Luiz Edson Fachin). São Paulo, Revista dos Tribunais, 2011 (Coleção doutrinas essenciais: obrigações e contratos. v. 5). p. 77-81.

${ }^{101}$ A fraude no direito civil. p. 310. 


\section{A PRESENÇA DA PROIBIÇÃO NAS LEGISLAÇÕES ESTRANGEIRAS E NA BRASILEIRA.}

\subsection{A proibição do pacto comissório nas legislações estrangeiras.}

\subsubsection{Observação inicial.}

Este capítulo 3 visa a apresentar um panorama da proibição do pacto comissório em diferentes países. Não se tem o propósito, nem a pretensão, de empreender qualquer esboço de comparação jurídica ${ }^{102}$. $\mathrm{O}$ argumento que se quer construir é apenas o seguinte: a proibição do pacto comissório é bastante difundida, sobretudo no direito continental europeu; há indícios, porém, de que ela começa a sofrer erosões, ou de que está a se disseminar uma percepção do seu anacronismo, ou dos limites mais estreitos em que ela se justifica. Serão investigadas, ainda, as disciplinas legais aplicáveis em países da América Latina e nos Estados Unidos da América. Como ponte para o capítulo 4, serão apresentados (a) breve histórico da vedação no direito brasileiro e (b) seus contornos na lei vigente.

\subsubsection{Portugal.}

Em Portugal, a proibição do pacto comissório é estabelecida no art. 694 do Código Civil: "É nula, mesmo que seja anterior ou posterior à constituição da hipoteca, a convenção pela qual o credor fará sua a coisa onerada no caso de o devedor não cumprir". Os artigos 678, 665 e 753 do mesmo código estendem a proibição, respectivamente, aos casos de penhor, consignação de rendimentos de bens imóveis (instituto aparentemente semelhante à anticrese) e simples privilégios creditórios. O texto da norma contempla, de modo expresso, a vedação ao pacto celebrado depois da constituição da garantia, sem fazer menção à circunstância de a dívida estar ou não vencida.

\footnotetext{
${ }^{102}$ Sobre a comparação jurídica, cf. R. SACCO. Introdução ao direito comparado. Trad. Véra Jacob de Fradera. São Paulo, Revista dos Tribunais, 2001.
} 
ANTUNES VARELlA qualifica a vedação como um princípio geral aplicável às hipotecas e, por consequência, às garantias reais em geral; como visto, o conteúdo do pacto é dado por nulo independentemente de o ajuste ter ocorrido antes ou após o vencimento ${ }^{103}$. Merece destaque o disposto no art. 675 do Código Civil português (com a redação dada pelo Decreto-lei n. ${ }^{\circ}$ 38, de 8 de março de 2003), segundo o qual é lícito ao credor e ao devedor acordarem a adjudicação do bem empenhado ao credor, segundo valor a ser determinado pelo Poder Judiciário.

Em 2001, o tribunal de Coimbra decidiu que, diante de penhor de direitos sobre aplicação financeira, era vedado ao banco credor - sob pena de caracterização de pacto comissório - liquidar a aplicação de titularidade do devedor e, com os recursos daí decorrentes, pagar-se mediante compensação; decidiu a corte que, a despeito da garantia constituída, o meio lícito para atingir o pagamento forçado era o processo de execução ou de cobrança, conforme a disponibilidade de título executivo ${ }^{104}$.

Assim, apesar da importante e reveladora mitigação que, a partir de 2003, passou a constar do art. 675 do Código Civil português, a proibição do pacto comissório está claramente presente na legislação desse país.

\subsubsection{Espanha.}

De acordo com o art. 1.859 do Codigo Civil espanhol: "El acreedor no puede apropiarse de las cosas dadas en prenda o hipoteca, ni disponer de ellas.". A proibição, segundo a letra do art. 1.884 da mesma lei, alcança igualmente a anticrese. $\mathrm{O}$ art. 1.872 desse código ainda estabelece regra importante para os objetivos deste trabalho, segundo a qual: "El acreedor a quien oportunamente no hubiese sido satisfecho su crédito, podrá proceder por ante Notario a la enajenación

\footnotetext{
103 J.M. ANTUNES VARELLA. Das obrigações em geral. v. II. p. 554-555.

104 A decisão é relatada por P.R. MARTineZ e P.F. DA PONTE. Garantias de cumprimento. p. 174. Trata-se do Acórdão n. 2832 do Tribunal da Relação de Coimbra, de 30 de janeiro de 2001. Os mesmos autores relatam também que, até meados dos anos 1990, o direito processual civil português contemplava procedimento especial de venda judicial do bem empenhado. Esse procedimento deixou de contar com previsão legal por força de reforma legislativa havida no ano de 1995 (Decreto-lei n. ${ }^{\circ}$ 329-A, de 12 de dezembro de 1995), ocasião em que passou a se remeter o credor pignoratício ao processo de execução por quantia certa. No mesmo sentido, cf. L.M.T. MENEZES LEITÃO. Garantias das obrigações. p. 196-197.
} 
de la prenda. Esta enajenación habrá de hacerse precisamente en subasta pública y con citación del deudor y del dueño de la prenda en su caso. Si en la primera subasta no hubiese sido enajenada la prenda, podrá celebrarse una segunda con iguales formalidades; y, si tampoco diere resultado, podrá el acreedor hacerse dueño de la prenda. En este caso estará obligado a dar carta de pago de la totalidad de su crédito.". Trata-se, como se vê, de procedimento assemelhado àquele previsto na legislação brasileira para a excussão do bem dado em alienação fiduciária (Decreto-lei n. ${ }^{\circ}$ 911/69, Lei n. ${ }^{\circ} 9.514 / 97$ e Lei n. $\left.{ }^{\circ} 10.931 / 04\right)$.

Na Espanha, é digna de nota a reflexão suscitada pela Resolução da Direção Geral dos Registros e Notariado, de 10 de junho de 1986. Essa resolução decorreu de controvérsia instaurada sobre a possibilidade de serem lavradas e registradas escrituras públicas que refletissem opções de compra sobre bens, outorgadas em garantia do pagamento de dívidas. A despeito de a jurisprudência dominante no Tribunal Supremo espanhol admitir como lícita a celebração de negócios fiduciários, a direção dos registros notariais espanhóis entendeu que tal opção de compra em garantia violava a proibição do pacto comissório, prevista nos artigos 1.859 e 1.884 do Codigo Civil ${ }^{105}$.

Fica demonstrada, portanto, a presença da proibição do pacto comissório também na legislação espanhola.

\subsubsection{Itália.}

Os artigos 2.744 e 1.963 do Codice Civile estatuem, em termos inequívocos, a proibição do pacto comissório: "2744. È nullo il patto col quale si conviene che, in mancanza del pagamento del credito nel termine fissato, la proprietà della cosa ipotecata o data in pegno passi al creditore. Il patto è nullo anche se posteriore alla costituzione dell'ipoteca o del pegno”; (...) “1963. È nullo qualunque patto, anche posteriore alla conclusione del contratto, con cui si conviene che la proprietà dell'immobile passi al creditore nel caso di mancato pagamento del

105 Contendo análise da controvérsia e da decisão, cf. M.I. FELIU REY. La prohibicion del pacto comissório y la opcion en garantia. Madrid, Editorial Civitas, 1995. p. 66-88. 
debito" ${ }^{\text {106 }}$. Ambas as normas preocupam-se em salientar que a nulidade por elas cominada alcança, igualmente, os pactos celebrados após a constituição da garantia. Assim como ocorre em Portugal, a lei italiana não veicula qualquer menção à circunstância de tal celebração se dar antes ou após o vencimento da obrigação garantida.

A Itália talvez seja o país em que houve o mais aceso e perene debate doutrinário e jurisprudencial sobre a vedação do pacto comissório. A bibliografia sobre o tema é particularmente farta, tanto no período anterior como posterior à edição do Codice Civile.

No período anterior a 1942, despontam como especialmente interessantes os artigos de CARNELUTTI ${ }^{107}$ e BETTI ${ }^{108}$, que ainda hoje constituem referências imprescindíveis para a compreensão dos possíveis fundamentos da proibição do pacto comissório, conforme se verá no capítulo $4^{109}$. No período posterior a 1942, são pertinentes as citações às monografias de LOJACONO ${ }^{110}$, BiAnCA $^{111}$ e VARrone ${ }^{112}$, e aos verbetes relativos ao tema no Novissimo Digesto Italiano, de autoria do próprio BIANCA e na Enciclopedia del Diritto, de autoria de CARNEVALI $^{113}$.

\footnotetext{
${ }^{106}$ Em tradução livre: "2744. É nulo o pacto pelo qual se estabelece que, na falta de pagamento do crédito no termo prazo fixado, a propriedade da coisa hipotecada ou dada em penhor passa ao credor. O pacto é nulo mesmo se posterior à constituição da hipoteca ou do penhor" (...) "1963. É nulo qualquer pacto, ainda que posterior à conclusão do contrato, pelo qual se estabeleça que a propriedade do imóvel passe ao credor no caso de falta de pagamento do débito".

${ }^{107}$ F. CARNELUTTI. Note sul patto commissorio. In: Studi di diritto processuale. v. I. Padova, Cedam, 1928. p. 487 a 492. Esse estudo consiste em comentário a decisão da Corte di Apelo di Venezia, tomada em 5 de setembro de 1916; foi inicialmente publicado na Rivista del diritto commerciale. 1916. v. II. p. 887 e ss.

${ }^{108}$ E. BETTI. Su gli oneri e i limiti dell'autonomia privata in tema di garanzia e modificazione di obbligazioni. Rivista del Diritto Commerciale e del Diritto Generale delle Obbligazioni. v. XXIX, parte II. Milano, Francesco Vallardi, 1931. p. 689 a 715 (de ora em diante citado como "Su gli oneri".

${ }^{109}$ Para um apanhado abrangente da bibliografia italiana sobre o tema, anterior ao Codice Civile, cf. C. M. BiancA. Patto comissorio (voce). Novissimo Digesto Italiano (diretto da Antonio Azara e Ernesto Eula). v. XII. Torino, UTET, 1965. p. 711-721.

${ }^{110}$ V. LOJACONO. Il patto comissorio nei contratti di garanzia. Milano, Giuffrè, 1952.

${ }^{111}$ C. M. BIANCA. Il divieto del patto comissório. Milano, Giuffrè, 1957.

${ }^{112}$ C. VARRONE. Il transferimento dela proprietà a scopo di garanzia. Napoli, Casa Editrice Eugenio Jovene, 1968.

${ }^{113}$ U. CARNEVAli. Patto comissório (voce). In: Enciclopedia del diritto. v. XXXII. Milano, Giuffré, 1982. p. 499-506.
} 
Um dos principais eixos do debate italiano é constituído pela questão da aplicabilidade da proibição às transferências fiduciárias de propriedade, ao redor da qual se organizam, por exemplo, as citadas obras de BiANCA e VARRONE. O assunto recebeu tratamento detido, igualmente, em comentários e tratados, de que são exemplos os trabalhos de ANDRIOLI ${ }^{114}$, RUBINO ${ }^{115}$ e BARBIERA ${ }^{116}$, devendo também ser citados os artigos de PUGLIATTI ${ }^{117}$ e RoPPO ${ }^{118}$.

A grande maioria dessas obras contempla indicações de julgados das cortes italianas sobre o assunto. Há ainda um número nada desprezível de artigos que, direta ou indiretamente, tratam do tema, ao se debruçarem sobre o pacto de retrovenda (patto de riscatto), a venda com escopo de garantia, o pacto marciano e o chamado sale lease-back ${ }^{119}$. Em certas análises mais contemporâneas, parece começar a se decantar a percepção de que é inconclusivo o debate sobre os fundamentos da proibição do pacto comissório, dada a incongruência entre essas

\footnotetext{
${ }^{114}$ V. ANDRIOLI. Commentario del Codice Civile a cura di Antonio Scialoja e Giuseppe Branca. Libro Sesto. Tutela dei diritti. Art. 2.740-2.899. Bologna, Nicola Zanichelli Editore, 1945. p. 49-54.

${ }_{115}$ D. RUBINO. La responsabilità patrimoniale. Il pegno. Seconda edizione. Torino, UTET, 1949. p. 525.

116 L. BARbIERA. Responsabilità patrimoniale. Disposizioni generali. In: Il Codice Civile. Commentario diretto da Piero Schlesinger. Art. 2740-2744. Milano, Giuffrè, 1991. p. 205-268.

${ }^{117}$ S. Pugliatti. Precisazioni in tema di vendita a scopo di garanzia. In: Diritto civile, MetodoTeoria-Pratica, Saggi. Milano, Giuffrè, 1951.

${ }^{118}$ V. ROPPO. Nota sopra il divieto del patto commissorio. In: ALPA, Guido; BESSONE, Mario; RoPPO, Enzo. Rischio contrattuale e autonomia privata. Napoli, Eugenio Jovene, 1982. p. 261-277.

${ }_{119}$ A análise dos artigos mais recentes da doutrina italiana sobre o tema consta da obra de A.G.N. LiQuidATO. $O$ contrato de penhor. Tese de doutorado. Faculdade de Direito da Universidade de São Paulo. São Paulo, 2012. p. 74-78; a consideração desses artigos consta também do trabalho de I.A. DE MAtos. O pacto comissório. Contributo para o estudo do âmbito da sua proibição. Coimbra, Almedina, 2006. Trata-se dos seguintes artigos: A. LUMINOSO. Alla ricerca degli arcani confini del patto commissorio. Rivista di Diritto Civile. Padova. v.36. n.2. p.219-242. mar./apr. 1990; M.G. CUBEDDU. Patto commissorio e vendita conpatto di riscatto: la risposta delle sezioni unite. Rivista di Diritto Civile. Padova. v.36. n.5. p.615-30. sept./ott. 1990; R. De Nictolis. Divieto del patto commissorio, alienazioni in garanzia e sale-lease-back. Rivista di Diritto Civile. Padova. v.37. n.5. p.535-69. sett./ott. 1991; I. RIVA. Il contratto di sale and lease back e il divieto di patto commissorio. Contratto e Impresa. Padova. v.17. n.1. p.300-24. gen./apr. 2001; e F. ANGELONI. Sulla responsabilità disciplinare del notaio che roghi un atto contenente un presunto patto commissorio. Contratto $e$ Impresa. Padova. v.16. n.3. p.1086-100. set./dic. 2000. A resenha desses artigos já foi realizada, com proficiência, por A.G.N. LIQUIDATO, sendo assim despicienda, aqui, a sua reprodução. Entende-se que essa tarefa também não se justifica pois, ainda que possa haver alguma atualização e citação de julgados e contribuições doutrinárias mais atuais, os argumentos essenciais debatidos pelos autores desses artigos, sobre os fundamentos do pacto comissório, são basicamente os mesmos de que cuidaram F. CARnelutti, E. Betti, C.M. Bianca, U. CARnevali, V. AndRioli, S. Pugliatti e D. RUBINO, nas obras acima citadas. Esses argumentos essenciais são reexaminados, com base no direito brasileiro, no capítulo 4 desta tese.
} 
possíveis justificativas, de um lado, e a sanção de nulidade absoluta que, por lei, é imposta à avença ${ }^{120}$.

Não há dúvida, no entanto, de que a vedação do pacto comissório está presente na legislação italiana.

\subsubsection{Alemanha.}

O BGB não destoa das demais codificações até aqui vistas, no que se refere a conter norma proibitiva do pacto comissório. A proibição consta da disciplina da hipoteca $(\$ 1.149)$ e do penhor ( $\$ 1.229)$. Uma das peculiaridades da lei alemã, nessa matéria, está em admitir a validade da dação em pagamento celebrada após o vencimento da obrigação. Essa parece ter sido a inspiração dos parágrafos únicos dos artigos 1.365 e 1.428 do Código Civil.

Trata-se de uma orientação legislativa que considera como marco primordial não a circunstância de a celebração ser posterior à constituição da garantia (como ocorre nas leis portuguesa e italiana), mas ser subsequente ao vencimento do débito. Segundo se relata, tão grande é o peso dado pelo direito alemão ao evento do vencimento - caracterizado como uma espécie de umbral para a licitude - que, antes de deflagrada a exigibilidade do débito, sequer se admite a validade do pacto comissório acompanhado de pacto marciano; a despeito disso, sustenta-se que a necessária proporção entre o débito e o valor do bem excutido estaria tutelada pelas regras gerais dos $\S \S 138$ e 139 do $\mathrm{BGB}^{121}$.

Também justificam destaque, na disciplina do BGB sobre o penhor, as regras contidas nos $\S \S 1.228,1.235$ e 1.221 . De acordo com esses dispositivos: (i) a satisfação do credor pignoratício deve se dar pela venda do bem objeto de penhor;

\footnotetext{
${ }^{120}$ M. I. BRUGI. Patto comissório (voce). Enciclopedia Giuridica. Roma, Instituto dela Enciclopedia Italiana (Treccani), 2010. p. 1-16, com amplo apanhado dos últimos desenvolvimentos da doutrina italiana sobre a matéria.

${ }^{121}$ Nesse sentido, M.I. FELIU REY. La prohibicion del pacto comissório y la opcion en garantia. p. 9699, com citações a M. Wolf e L. RAISER. Tratado de derecho civil. Derecho de cosas. v. III-2. Trad. Pérez González y Alguer). Barcelona, Bosch, 1971; e a obra aparentemente pioneira sobre o tema no direito alemão, que é a de L. RAAPE. Verfallklausel bei Pfand und Sicherung-Übereignung. Berlin, F. Vahlen, 1913.
} 
(ii) essa venda pode ser realizada pelo credor pignoratício tão logo o débito esteja vencido, no todo ou em parte; (iii) se o crédito amparado pelo penhor não consiste em direito a prestação pecuniária, somente se admite a venda mediante a conversão do objeto da prestação em uma quantia de dinheiro; (iv) em princípio, a venda do bem objeto de penhor deve se dar em hasta pública; mas (v) se tal objeto tem preço cotado em bolsa de valores ou mercado com características equivalentes, a venda destinada à satisfação do credor pode ser feita em caráter privado, pelo preço estabelecido na bolsa ou mercado, por corretor ou leiloeiro a tanto habilitado. Essas regras, como se notará mais adiante, guardam interessante proximidade com aquelas do direito norte-americano; os princípios a elas subjacentes serão importantes para o desenvolvimento da tese $\mathrm{e}^{122}$.

Em que pesem esses matizes, a lei alemã não deixa de conter, também ela, a previsão de nulidade do pacto comissório, que por definição é aquele celebrado antes do vencimento da obrigação.

\subsubsection{França.}

A legislação francesa foi pioneira, no direito continental europeu, em reconhecer como descabida a pura e simples proibição do pacto comissório. $\mathrm{Na}$ França, o pacto comissório passou a ser expressamente admitido nos contratos de penhor celebrados a partir de 25 de março de 2006 (art. 2.348 do Code Civil); naqueles celebrados antes dessa data, a proibição permanece, mas - e aqui se tem outra originalidade do direito francês - a sanção aplicável é da anulabilidade, sendo admitida a renúncia do devedor à pretensão correspondente ${ }^{123}$.

AYNÉS e CROCQ relatam que, historicamente, a proibição do pacto comissório foi entendida na França em termos bastante rígidos, que excluíam do

\footnotetext{
${ }^{122}$ Os dispositivos do BGB foram compreendidos com o auxílio do v. II (apêndices) de D. MEDICUS. Tratado de las relaciones obligacionales. Trad. Ángel Martínez Sarrión. Barcelona, Bosch, 1995, que contém a tradução para o espanhol de diversos parágrafos do BGB e de outras leis alemãs.

${ }^{123}$ L. AYNes e P. CROCQ. Les sûretés. La publicite foncière. p. 239. Antes da modificação, a interdição constava do art. 2.078 do Code Civil e era como tal reconhecida pela doutrina francesa, cf. E. BECQUÉ. Sûretés réelles. $1^{\text {ere }}$ partie. In : Traité pratique de droit civil français par Marcel Planiol et George Ripert. 2a. ed. Paris, LGDJ, 1953. p. 135-136 ; e M. JUGLART. Sûretés - publicité foncière. v. I. In: Leçons de droit civil. t. III. (Henri, Léon et Jean Mazeau).3a ed. Paris, Montchrestien, 1968. p. 76-77.
} 
campo da licitude até mesmo a versão conjugada com pacto marciano; a jurisprudência francesa contemporânea, teria amainado o rigor da vedação, sobretudo diante da larga difusão das garantias fiduciárias; esses autores citam ainda julgados em que o pacto foi admitido em relação à hipoteca (na França, quando havia a vedação, era ela direcionada nominalmente ao penhor), e outros nos quais se aceitou a licitude (i) do pacto comissório ex intervallo, (ii) da figura da opção de compra em garantia e (iii) da celebração do pacto comissório no contexto da caução de créditos ou depósitos em dinheiro; essa mitigação, porém, não significou o desaparecimento da proibição, havendo decisões que estendiam a proibição aos casos de caução de valores mobiliários $^{124}$.

Salientam os mesmos autores que o alcance prático da permissão à celebração do pacto comissório - introduzida pela ordonnance de 23 de março de 2006 - seria reduzido. Esse alcance limitado decorre da permanência da proibição nos contratos de crédito ao consumidor e nos casos em que venha a ser aberto processo de salvaguarda do devedor ou insolvência (recuperação ou falência) ${ }^{125}$. A ausência de proteção do credor adquirente do bem dado em garantia por força de pacto comissório, em caso de falência ou recuperação do devedor, realmente, parece esterilizar uma das principais funções esperadas desse pacto, conforme se viu no item $2.2^{126}$

Para melhor compreender a posição do tema na legislação francesa, é útil atentar para as circunstâncias em que se deu a edição da referida ordonnance. Essa modificação legislativa foi fruto de um esforço coletivo e dirigido, que objetivava a modernização das garantias no direito francês ${ }^{127}$. A elaboração do correspondente projeto de lei foi confiada a uma comissão presidida pelo Prof. Michel Grimaldi, da Université Pantheon-Assas (Paris II), e também presidente da

\footnotetext{
${ }^{124}$ L. AYNES e P. CROCQ. Les sûretés. La publicite foncière. p. 239-240.

${ }^{125}$ L. AYNES e P. CROCQ. Les sûretés. La publicite foncière. p. 241.

${ }^{126}$ Sobre as importantes correlações entre a disciplina dos direitos reais de garantia, de um lado, e a disciplina da insolvência e das execuções coletivas, no direito francês, cf. P. CROCQ. The recent influence of insolvency law on the evolution of security in French law. In: Current issues in European financial and insolvency law. Perspectives from France and the UK. Edited by Wolf-Georg Ringe, Louise Gullifer and Philippe Théry. Oxford and Portland Oregon, Hart Publishing, 2009. p. 129-136.

${ }^{127}$ REPUBLIQUE FRANÇAISE. Rapport au Président de la République relatif à l'ordonnance $n .^{\circ} 2006-$ 346 du 23 mars 2006 relative aux sûretés. Journal Officiel de la République Française, edition de 24 mars 2006 (consultado no sítio da Association Henri Capitant des Amis de la Culture Juridique Française - www.henricapitant.org, acesso em 01.10.2012).
} 
Association Henri Capitant des Amis de la Culture Juridique Française. Integraram o grupo, nomeado em 2003 pelo Ministério da Justiça da França, o Prof. Laurent Aynés (Pantheon-Sorbonne, Paris I), Annie Bac (Fédération Bancaire Française), Prof. Pierre Crocq (Pantheon-Assas, Paris II), Dominique Dos-Reis (conseiller à la Cour d'Appel de Paris), Éliane Frémeaux (notaire à Paris), Alain Gourio (Banque BNP-Paribas), Alain Provansal (avocat au Barreau de Marseille), Philippe Simler (Université Robert Schuman de Strasbourg) e Prof. Hervé Synvet (Pantheon-Assas, Paris II) ${ }^{128}$.

O relatório do referido grupo de trabalho situa o término da proibição do pacto comissório entre as medidas destinadas a facilitar e simplificar os modos de realização das garantias; sustentou a comissão que essa medida não era incompatível com a proteção do devedor e dos demais credores, uma vez que a transferência de propriedade, por força do pacto comissório, exige a determinação do valor do bem, na data da transferência, por um perito designado por consenso ou judicialmente, salvo se houver cotação do bem dado em garantia em bolsa ou mercado de balcão organizado ${ }^{129}$. Caso o valor assim apurado exceda o valor da dívida, o credor deve restituir esse excesso ao devedor ou consigná-lo, caso existam outros credores pignoratícios; qualquer cláusula contratual que vise a eliminar ou obviar essa exigência de avaliação independente é reputada não escrita (artigos 2.347 e 2.348 do Code Civil, com a redação dada pela ordonnance n. ${ }^{\circ} 2006.348$, de 23 de março de 2006) ${ }^{130}$. Inexistindo pacto comissório, a realização da garantia apenas

\footnotetext{
${ }^{128}$ RePUblique FranÇAISE. Rapport à Monsieur Dominique Perben, Garde des Sceaux, Ministre de la Justice, issue par le Groupe de travail relatif à la reforme du droit des sûretés (consultado no sítio da Association Henri Capitant des Amis de la Culture Juridique Française - www.henricapitant.org, acesso em 01.10.2012).

${ }^{129}$ Como visto no item 3.1.5, essa sistemática é semelhante àquela prevista nos $\S \S 1.228,1.235 \mathrm{e}$ 1.221 do BGB.

${ }^{130}$ RePUBliQue FrAnÇAISE. Rapport à Monsieur Dominique Perben, Garde des Sceaux, Ministre de la Justice, issue par le Groupe de travail relatif à la reforme du droit des sûretés (consultado no sítio da Association Henri Capitant des Amis de la Culture Juridique Française - www.henricapitant.org, acesso em 01.10.2012), p. 12 e REPUBLIQUE FRANÇAISE. Rapport au Président de la République relatif à l'ordonnance $n .^{\circ}$ 2006-346 du 23 mars 2006 relative aux sûretés. Journal Officiel de la République Française, edition de 24 mars 2006 (consultado no sítio da Association Henri Capitant des Amis de la Culture Juridique Française - www.henricapitant.org, acesso em 01.10.2012), cujo item 1.2.2.2.1.2, Modes de réalisation du gage, contém passagem que cumpre reproduzir: «L'article 2348 met fin à lá prohibition du pacte commissoire puisqu'il permet aux parties de convenir lors de la constitution du gage ou postérieurment que le créancier deviendra propriétaire du bien en cas de défaillance du débiteur. Le créancier dispose ainsi d'un mode de réalisation du bien gagé simple, rapide et peu onéreux et ce d'autant que l'évaluation du bien pourra, le cas échéant, être réalisée par référance à sa cotation officielle sur un marché organisé au sens du code monetáire et financier, le
} 
pode se dar pelos meios expressamente previstos na legislação processual civil, sendo nula qualquer avença em sentido diverso (art. 2.346 do Code Civil com a redação dada pela ordonnance n. ${ }^{\circ} 2006.348$, de 23 de março de 2006).

A referida ordonnance modificou ainda o art. 622-7 do Code de Commerce, para prever que o início de um processo judicial de proteção do devedor (análogo à recuperação judicial) ou de concurso de credores constitui obstáculo à celebração e efetivação de pactos comissórios. Essa previsão traz elementos interessantes para a discussão sobre os fundamentos da proibição do pacto comissório, a serem analisados no capítulo 4.

Registre-se, por fim, que se deu atenção, aqui, apenas aos aspectos dessa reforma legislativa atinentes especificamente à proibição do pacto comissório. Essa reforma foi bastante mais ampla. Ela consistiu em uma notável e qualificada reflexão sobre as garantias de modo geral, incluindo as garantias pessoais, a hipoteca, a caução e o penhor de estoques e valores mobiliários. Esses temas transbordam os limites mais estreitos desta tese.

\subsubsection{Argentina.}

Sem fazê-lo, de modo expresso, em relação à hipoteca, a legislação argentina proíbe o pacto comissório ao disciplinar o penhor e a anticrese. O art. 3.222 do Codigo Civil argentino prevê a nulidade de toda e qualquer cláusula que autorize o credor a se apropriar do objeto empenhado ou de dispor dela de modo diverso dos

recours à l'expertise n'etant exigé qu'à défaut de telle cotation. En revanche, toute clause ayant pour objet contourner ces modalités d'evaluation sera réputée non écrite. Afin de limiter de développement de clauses types, l'article 27 du projet d'ordonnance modifie l'article L.311-32 du code de la consommation afin de réputer non ecrits les pactes commissoires conclus dan les contrats de crédits mobiliers à la consommation ». Em tradução livre : «Modos de realização do penhor. O art. 2348 põe fim à proibição do pacto comissório, uma vez que permite às partes acordarem, desde a constituição do penhor ou posteriormente, que o credor se tornará proprietário do bem em caso de descumprimento pelo devedor. O credor dispõe assim de um modo de realização do bem empenhado simples, rápido e pouco oneroso e ao passo que a avaliação do bem possa, no caso concreto, ser realizada por referência à sua cotação oficial em um mercado organizado, no sentido estabelecido pelo código financeiro e monetário, o recurso a um perito avaliador não será exigido a não ser na falta dessa cotação. Por outro lado, toda cláusula que visar a contornar as formas legais de avaliação será reputada não escrita. A fim de limitar o desenvolvimento de cláusulas-padrão, o art. 27 do projeto de lei modifica o art. L. 311-32 do código de defesa do consumidor para reputar não escritos os pactos comissórios insertos em contratos de financiamento de bens móveis ao consumidor". 
legalmente admitidos, ainda que o valor do bem seja inferior ao montante da dívida. É igualmente cominada, com nulidade, a cláusula que procure privar o credor do direito de solicitar a venda da coisa dada em garantia.

O dispositivo seguinte - art. 3.223 - é o primeiro até aqui encontrado que explicitamente trata do pacto marciano, como mecanismo capaz de eliminar a ilicitude do pacto comissório ${ }^{131}$; a avaliação do bem, contudo, deve ocorrer por ocasião do vencimento da dívida, e não no momento da constituição da garantia.

A tolerância da lei argentina para com o pacto marciano, porém, não tem lugar em relação à anticrese. O art. 3.252 do mesmo código, além de reproduzir a proibição do pacto comissório no âmbito da anticrese, estende expressamente a sanção de nulidade à cláusula pela qual o credor se torne proprietário do imóvel por preço fixado por peritos escolhidos de comum acordo entre as partes, ou mesmo de ofício. Não sem alguma perplexidade, diante dessa rigidez em relação à anticrese, lêse no artigo seguinte uma autorização expressa para que o credor compre do devedor o bem objeto do ônus, tanto antes como depois do vencimento do débito.

\subsubsection{Chile.}

O código civil chileno estabelece a nulidade do pacto comissório em seu art. 2.397. Ao tratar da realização dos direitos do credor pignoratício, essa norma prevê: (a) que em caso de mora do devedor, o direito do credor pignoratício é o de obter a venda do bem em hasta pública, a fim de se pagar com o produto da alienação; (b) na falta de oferta de aquisição por terceiros, é admitida a adjudicação do bem ao credor, desde que o valor do bem seja determinado por peritos e que a imputação ao montante do crédito se dê apenas até o valor assim determinado, sem prejuízo de outras formas de cobrança do crédito; qualquer outro modo de disposição ou apropriação do bem empenhado, distinto dos expressamente previstos, é tido por ilícito. $\mathrm{O}$ art. 2.424 do código civil chileno estatui a aplicação dessas mesmas regras à realização dos direitos do credor hipotecário.

131 “Art. 3.223. El deudor, sin embargo, puede convenir con el acreedor en que la prenda le pertenecerá por la estimación que de ella se haga al tiempo del vencimiento de la deuda, pero no al tiempo del contrato". 


\subsubsection{México.}

O codigo civil federal mexicano estabelece que, em caso de mora do devedor pignoratício: (a) o credor pode pedir judicialmente a venda do bem empenhado (art. 2.881); (b) mostrando-se infrutífera a venda, o credor pode obter a adjudicação do bem, nos termos da lei processual (art. 2.882); (c) é expressamente reconhecida a licitude do pacto marciano, desde que a avaliação ocorra quando do vencimento da obrigação, e não quando da constituição da garantia, e desde que tal pacto não prejudique direitos de terceiros (art. 2.883); e (d) é admitida, se contratualmente prevista, a venda extrajudicial do bem (art. 2.884).

Em termos semelhantes àqueles contidos no código civil argentino (art. 3.222), a lei mexicana comina com nulidade o pacto comissório, entendido como aquele que autoriza o credor a se apropriar do bem empenhado, ainda que de valor inferior ao montante da dívida, ou a dele dispor de modo diverso daqueles expressamente admitidos pelas regras descritas no parágrafo anterior (art. 2.887 do código civil federal). A proibição não está expressa em relação à hipoteca, embora seja feita remissão à legislação processual para a indicação dos modos de realização dos direitos do credor hipotecário (art. 2.916) e se afirme que o credor pode adquirir o bem hipotecado em arrematação judicial. A contrario sensu, não seria admitida outra forma de aquisição do bem pelo credor hipotecário. O mesmo artigo 2.916 é também expresso a respeito da validade do pacto marciano em sede de hipoteca.

\subsubsection{Estados Unidos da América.}

Embora nos Estados Unidos da América a competência legislativa para o tema seja estadual, a quase totalidade dos estados norte-americanos adota como lei própria a disciplina do chamado Article (\$) 9 do Uniform Commercial Code ("UCC"). O $\$ 9^{\circ}$ do UCC é um diploma legislativo de enorme riqueza e 
complexidade. Desse farto manancial, interessa aqui apenas colher os aspectos mais salientes das normas atinentes à excussão de garantias, de modo que seja possível compará-las, ainda que de modo perfunctório, com as demais legislações consideradas.

A disciplina aplicável ao inadimplemento de dívidas amparadas por garantias consta da parte 6 do Article 9, intitulada simplesmente Default ${ }^{132}$. Um dos primeiros aspectos a sublinhar, nesse conjunto normativo, é o §9-602, que contém lista detalhada das regras cogentes do capítulo, insuscetíveis de modificação por contrato ou de renúncia pelo devedor ou seus coobrigados. Nesse aspecto, a disciplina norte-americana difere significativamente de certas legislações, como a alemã ou a brasileira, nas quais se supõe que a maior fragilidade do devedor estaria no momento da constituição da dívida ou da garantia, e não após o vencimento; na Alemanha e no Brasil, inclusive, é amplamente autorizada, sem quaisquer restrições, a dação em pagamento do bem objeto de garantia, após o vencimento da dívida. $\mathrm{O}$ comentário oficial a respeito dessa seção 602 lê-se que o momento mais delicado e propício a abusos dos credores contra devedores é justamente aquele subsequente à impontualidade: "the context of default offers great opportunity for overreaching. The suspicious attitudes of the courts have been grounded in common sense. This section, like former Section 9-501(3), codifies this long standing and deeply rooted attitude"133.

Com base nesses fundamentos, são qualificadas como cogentes as regras sobre uso e operação do bem dado em garantia pelo credor garantido (Section 9-207(b) $(4)(C))$, requisições de extratos e demonstrativos da dívida garantida ou dos bens dados em garantia (Section 9-210), apossamento e excussão da garantia (inclusive no que se refere à obrigação de retomar a posse do bem "without breach of the peace" (Sections 9-607(c) e 9-609), imputação e pagamento de cobranças in

\footnotetext{
${ }^{132}$ Usa-se como referência a versão do texto legal que contém os chamados official comments, cf. edição organizada pela Professora da Universidade de Harvard Elizabeth Warrren. Bankruptcy and Article 9. 2010 Statutory supplement. Austin, Boston, Chicago, New York, The Netherlands, Wolters Kluwert, 2010 (de ora em diante citado apenas como Statutory supplement).

${ }^{133}$ Tradução livre: "o contexto do inadimplemento oferece grande oportunidade para o abuso. A postura de desconfiança das cortes a esse respeito esteve baseada no bom senso. Este artigo, assim como o anterior 9-501(3), codifica essa postura longamente sedimentada e profundamente enraizada". E. Warren. Statutory supplement. p. 191-192.
} 
natura (via excussão ou alienação) (Sections 9-608(a) e 9-615(c)), cálculo, apuração, prestação de contas e devolução de excessos apurados na excussão da garantia (Sections 9-608(a), 9-615(d) e 9-616), alienação do bem dado em garantia (Sections 9-610(b), 9-611, 9-613 e 9-614), cálculo de déficit ou excesso nos recursos obtidos com alienação do bem dado em garantia ao próprio credor garantido ou a pessoa a ele relacionada (Section 9-615(f)), aceitação do bem dado em garantia como pagamento da dívida (Sections 9-620, 9-621 e 9-622), remição de garantia (Section 9-623), renúncias admitidas (Section 9-624) e responsabilidade do credor garantido por eventual descumprimento das referidas normas cogentes (Section 9-625 e 9-626).

Entre os dispositivos que não admitem renúncia ou modificação por contrato está aquele que obriga o credor garantido a proceder de modo comercialmente razoável em relação a todos os aspectos da alienação do bem garantido, em caso de inadimplemento, incluindo método, maneira, tempo, lugar e quaisquer outros termos (Section 9-610(b)). A norma imediatamente anterior (Section 9-610(a)) assegura ao credor garantido o direito de, a qualquer tempo após o inadimplemento, vender, alugar, licenciar e de qualquer outro modo dispor do bem dado em garantia.

A possibilidade de compra do bem dado em garantia pelo próprio credor garantido - que guarda relação com o pacto comissório - está prevista na Section 9-610(c). De acordo com esta regra, que em princípio não é cogente, a aquisição do bem dado em garantia pelo próprio credor garantido apenas pode ocorrer (a) em hasta pública (public disposition); ou (b) privadamente, nos casos em que o bem é costumeiramente negociado em um mercado reconhecido ou $\operatorname{organizado}^{134}$, ou naqueles em que existe cotação de preço padronizada e amplamente divulgada. "Public disposition", por sua vez, significa aquela alienação em que o preço é determinado depois de quaisquer terceiros terem uma oportunidade significativa de apresentar ofertas concorrentes, isto é, depois de ter havido alguma forma de publicidade efetiva sobre a ocorrência da venda e depois de ter se aberto a

\footnotetext{
${ }^{134}$ De acordo com o comentário oficial (E. WARREN. Statutory supplement. p. 199), um mercado reconhecido é aquele em que os bens negociados são fungíveis e os preços não estão sujeitos a negociações individuais. O exemplo indicado é o da bolsa de valores de Nova Iorque (New York Stock Exchange).
} 
possibilidade de terceiros apresentarem lances para a compra do bem dado em garantia.

Transparece, nessas regras, a preocupação com o preço pelo qual o bem dado em garantia passa ao patrimônio do credor garantido. Essa preocupação não é veiculada, porém, por uma pura e simples proibição da aquisição do bem pelo credor, mas pela fixação de procedimentos destinados a garantir que tal transferência se dará em termos comercialmente razoáveis. Tal como se viu no âmbito da lei alemã (item 3.1.5) e da lei francesa (item 3.1.6), a summa divisio nessa matéria diz respeito à existência ou não de cotações públicas e confiáveis de preços, ou de mercado organizado em que seja negociado o bem dado em garantia. Se tais cotações e mercados existem, logo há critérios disponíveis para aferir se há uma proporção correta entre o valor de mercado do bem e o valor da dívida; por isso se autoriza a venda privada. Todavia, se tais cotações e mercados não existem, não se dispõe de critérios claros para aferir eventual excesso do valor de mercado do bem garantido em relação ao valor da dívida. Por tal razão, nesses últimos casos, exige-se a venda pública, isto é, aquela em que terceiros - diante de um preço vil ou simplesmente baixo em comparação com o praticado em mercado - teriam incentivos e oportunidade para cobrir o preço proposto pelo próprio credor garantido.

O comentário oficial explica que, apesar de não ser suficiente para caracterizar uma violação à lei, o preço baixo indica a necessidade de os tribunais realizarem um escrutínio cauteloso sobre todos os aspectos do procedimento de alienação do bem dado em garantia ${ }^{135}$. Mais a frente, ao discorrer sobre os critérios cogentes de aferição de déficit ou excesso nos casos em que o adquirente do bem dado em garantia é o próprio credor garantido, ou parte a ele relacionada, o mesmo comentário oficial reconhece que, nesses casos, falta ao credor o incentivo necessário para maximizar o produto da venda ${ }^{136}$. Para tentar corrigir esse problema, a Section 9-615(f) estabelece que, nessa hipótese, a aferição sobre a ocorrência de déficit ou excesso no produto da venda, em relação ao valor da dívida, deve ser feita considerando-se o preço que um terceiro independente pagaria pelo bem dado em garantia, e não o preço efetivamente aceito pelo credor ou por parte a ele relacionada.

${ }^{135}$ E. WARREN. Statutory supplement. p. 199.

${ }^{136}$ E. WARREN. Statutory supplement. p. 205. 
Afora os casos de compra propriamente dita, que recebem o tratamento brevemente descrito acima, as normas da Section 9-620 cuidam especificamente da aceitação do bem dado em garantia em pagamento parcial ou total do débito, isto é, sem que ocorra uma venda pública ou privada do bem. Em síntese, os diversos itens desse dispositivo estabelecem que o credor garantido pode licitamente aceitar o bem dado em garantia em pagamento total ou parcial do débito, desde que para tanto conte com os consentimentos (a) do devedor - manifestado sempre e necessariamente por escrito, após o inadimplemento e, cumulativamente (b) de terceiros credores que tenham interesses subordinados sobre o bem dado em garantia, como hipotecas de segundo grau, por exemplo. Nos casos em que o credor garantido busca a satisfação total do débito mediante dação em pagamento, esse consentimento do devedor pode ser explícito ou apenas inferido a partir da ausência de objeção durante determinado período, após o recebimento de notificação a esse respeito. Se, todavia, o propósito do credor garantido é o de obter a satisfação apenas parcial do débito, permanecendo o devedor responsável pelo déficit entre o valor do bem e o montante da dívida, não se admite o consentimento implícito, isto é, inferido apenas pela ausência de objeção após notificação, sendo imprescindível a manifestação expressa de concordância pelo devedor. A satisfação apenas parcial da dívida, mediante dação em pagamento do bem dado em garantia, é vedada se o devedor for consumidor; a contrario sensu, havendo relação de consumo, a dação em pagamento, se ocorrer com o consentimento do devedor, quitará integralmente a dívida, independentemente do valor de mercado do bem.

A disciplina legal norte-americana é clara sobre a exigência de o consentimento do devedor para com a dação em pagamento do bem ter que ser manifestado após o vencimento da dívida (after default). Fica excluída do campo da licitude, portanto, a avença segundo a qual esse consentimento seja anterior ao vencimento da dívida, devendo-se reiterar que a referida Section 9-620 não comporta renúncia pelo devedor, nem modificação por contrato (cf. Section 9-602).

Não parecem corretas, portanto, as afirmações de ENEI e PENTEADO, no sentido de que o direito norte-americano aceita o pacto comissório, desde que o 
devedor a tanto não se oponha ${ }^{137}$, ou desde que observado certo procedimento. O que o Article 9 do UCC admite nada mais é do que a dação em pagamento do bem, após o vencimento, admitindo em certos casos que a concordância do devedor, mesmo não sendo expressa, possa ser inferida pelas circunstâncias. Nada substancialmente diferente do que já se lê nos parágrafos únicos dos artigos 1.365 e 1.428 do Código Civil e nos parágrafos do BGB citados no item 3.1.5. Ao contrário do que sustentam os citados autores, esta tese entende que o pacto comissório propriamente dito, que é a cláusula avençada antes do vencimento, por força da qual, em caso de inadimplemento, a titularidade do bem dado em garantia passa de imediato para o credor, é igualmente repelida pelo direito norte-americano.

Mesmo sem comungar da tradição do direito continental europeu, o direito norte-americano compartilha de preocupações que são convergentes com aquelas presentes nas discussões sobre os fundamentos da proibição do pacto comissório, como se verá no capítulo 4. As regras do Article 9-610, 9-615 e 9-620, em especial, iluminam de modo notável os conflitos de interesses que se apresentam na constituição e excussão de bens dados em garantia, tanto no plano das relações bilaterais entre devedor e credor, como também no plano mais geral que considera a coletividade dos credores do devedor. Esses dispositivos constituem importantes subsídios para esta tese.

\subsubsection{Resumo analítico.}

O que se pode extrair, analiticamente, desse panorama legislativo? Em primeiro lugar, verifica-se a presença disseminada da proibição do pacto comissório nas diferentes legislações. Em segundo lugar, e mais importante, podem ser identificadas certas particularidades que, para os fins desta tese, reclamam especial atenção. São elas: (a) em Portugal, a reforma legislativa de 2003, pela qual se passou a permitir que credor e devedor pignoratícios cometam ao Poder Judiciário a avaliação do preço pelo qual se opera a adjudicação do bem dado em garantia ao credor, em caso de inadimplemento da dívida, o que não deixa de ser uma modalidade peculiar de pacto marciano, em que o papel do avaliador isento é

${ }^{137}$ J.V.L. ENEI. Project finance. São Paulo, Saraiva, 2007. p. 236; e M.B. PENTEAdO. O penhor de ações no direito brasileiro. São Paulo, Malheiros, 2008. p. 202. 
exercido pelo juiz; (b) na Itália, o caráter inconclusivo dos aprofundados debates doutrinários sobre os fundamentos da proibição do pacto comissório, bem como das controvérsias, tanto doutrinárias quanto jurisprudenciais, sobre a extensão dessa proibição às transferências fiduciárias de propriedade, à compra e venda com pacto de retrovenda e ao esquema negocial do sale and lease-back; (c) na Alemanha, as disposições dos $\S \S 1.228,1.235$ e 1.221 do BGB, segundo as quais é autorizada a venda privada do bem empenhado, independentemente da outorga de mandato ao credor, nos casos em que o bem for negociado em bolsa ou mercado organizado, ou em que houver cotação de preços publicamente disponível; (d) na França, a reforma legislativa de 2006, que eliminou do Code Civil a proibição do pacto comissório, exceção feita às relações para consumo e à elucidativa ineficácia do pacto diante da instauração de procedimento judicial de proteção do devedor (análogo à recuperação judicial) ou de execução coletiva; cabe registrar, ainda, o caráter cogente das regras sobre a avaliação do preço de mercado do bem dado em garantia, para fins de sua utilização em pagamento do débito; (e) na Argentina, a previsão legal de mecanismo equivalente ao pacto marciano, qualificado como apto a expurgar a ilicitude do pacto comissório; (f) no Chile, a previsão da avaliação do valor do bem por terceiro independente, como requisito para a adjudicação do bem dado em garantia em favor do credor pignoratício; (g) no México, a previsão legal expressa, no sentido da validade do pacto marciano e da possibilidade de venda extrajudicial do bem dado em garantia, se contratualmente prevista; e (h) nos Estados Unidos da América, a disciplina da alienação pelo credor do bem dado em garantia, que admite a compra privada se o bem é negociado em bolsa ou mercado organizado, ou dispõe de cotação de preço publicamente disponível, mas que, na ausência de tais circunstâncias, exige que tal aquisição, se levada a efeito pelo próprio credor garantido, dê-se publicamente; ainda no direito norte-americano, a exigência de concordância do devedor - manifestada após o vencimento - como requisito necessário para a possibilidade de dação em pagamento do bem dado em garantia, em adimplemento parcial ou total do débito, e o caráter cogente desta última regra. Roga-se ao paciente leitor que guarde em mente este apanhado analítico. Ele ajudará a apoiar as conclusões que se pretende sejam alcançadas ao final do capítulo 4. 


\subsection{Histórico da proibição na legislação brasileira.}

\subsubsection{Período anterior ao Código Civil de 1916.}

“O Direito, no Brasil, não pode ser estudado desde as sementes; nasceu do galho de planta, que o colonizador português, - gente de rija têmpera, no ativo século XVI e naquele cansado século XVII em que se completa o descobrimento da América - trouxe e enxertou no novo continente." 138

No direito luso-brasileiro, há notícia segura sobre a vigência da proibição do pacto comissório ao menos desde as Ordenações Alfonsinas (de 1446). Tais ordenações tratavam do tema em seu Livro IV, Título XXXVIII, segundo o qual a cláusula pela qual o objeto do penhor ficava "rematado ao creedor por a divida", em caso de inadimplemento, era tida "contra Direito" e de "nenhum valor"139. Era igualmente repelida a cláusula pela qual tal transferência de titularidade se desse por preço estimado pelo próprio credor. Admitia-se, no entanto, que o credor ficasse com o bem empenhado "pelo justo preço", determinado por "dous homees boõs juramentados, e escolheitos polas partes, a saber, per cada hum seu" ${ }^{140}$. Em outras palavras, havia autorização expressa para o uso lícito e conjunto dos pactos comissório e marciano. A mesma disciplina legal continuou a constar das Ordenações Manuelinas (de 1514, Livro IV, Título XXVI) e das Ordenações Filipinas (de 1603, Livro IV, Título LVI).

Para que se tenha clareza sobre o legado das Ordenações Filipinas, e dada a relevância deste ponto para o argumento principal da tese, deve-se transcrever o que delas constava sobre o tema:

\footnotetext{
${ }^{138}$ F.C. PONTES DE MIRANDA. Fontes e evolução do direito civil brasileiro. $2^{\mathrm{a}}$ edição. Rio de Janeiro, Forense, 1981. p. 27.

${ }^{139}$ I.A. DE MATOS. O pacto comissório. p. 45-46.

${ }^{140}$ I.A. DE MATOS. O pacto comissório. p. 46.
} 
"Título LVI Dos que apenham seus bens com condição, que não pagando a certo dia, fique o penhor arrematado. Se algum devedor empenhar a seu credor alguma cousa móvel, ou de raiz, com a condição que, não lhe pagando a dívida, a dia certo, o penhor fique por ella vendido e arrematado ao credor, mandamos que tal convença seja nenhuma e de nenhum effeito. Porém, se o devedor der alguma cousa sua em penhor a seu credor sob condição, que não lhe pagando a tempo certo, fique o penhor arrematado pelo justo preço, a tal apenhamento assi feito valerá, e a convença será guardada. E em este caso, o penhor será estimado depois do tempo da paga por dous homens bons juramentados e escolhidos pelas partes, convem a saber, per cada hum seu, e ficará rematada ao credor por o preço, em que for estimado. E se ao tempo do empenhamento fosse acordado entre as partes, que o penhor fosse arrematado ao credor por o preço, que pelo credor fosse estimado, mandamos que o empenhamento feito desse modo não valha cousa alguma; porque he grande presunção, que facilmente se moverá a fazer estimação não verdadeira, posto que lhe para isso seja dado juramento, e por tanto não he razão darmoslhe azo para jurar o contrário da verdade. ${ }^{141,}$

Não divergem do exposto acima as manifestações de COELHO DA ROCHA $^{142}$ e CORREA TELLES ${ }^{143}$. O primeiro destaca que a razão de ser da nulidade cominada pelo pacto comissório não está em o credor ficar com o bem empenhado, mas sim em fazê-lo sem avaliação, ou com avaliação feita por ele mesmo; se o pacto é acompanhado de ajuste sobre a realização dessa avaliação, com a participação de peritos nomeados por credor e devedor, deixa de haver razão para a invalidade. $\mathrm{O}$ segundo autor, por sua vez, faz afirmação de todo semelhante, asseverando que

\footnotetext{
${ }^{141}$ Ordenações Filipinas. Reprodução fac-simile da edição feita por Candido Mendes de Almeida no Rio de Janeiro em 1870. Lisboa, Calouste Gulbenkian, 1985. p. 850.

${ }^{142}$ M.A. COElHO DA RochA. Instituições de direito civil portuguez, para uso de seus discípulos. t. II. $2^{\text {a }}$ edição. Coimbra, Imprensa da Universidade, 1848. p. 494-495.

${ }^{143}$ J.H. CORREA TELlES. Digesto portuguez ou Tractado dos modos de adquirir a propriedade de a gozar e administrar e de a transferir por derradeira vontade para servir de subsídio ao Novo Código Civil. t. III. 5a edição. Coimbra, Livraria J. Augusto Orcel, 1860. p. 193-195.
} 
"Póde porém ajustar-se que se o devedor não pagar até certo tempo, o credor ficará com o penhor pelo valor, em que for avaluado por louvados" $" 144$.

$\mathrm{Na}$ Consolidação das Leis Civis, a matéria era tratada, essencialmente, nos artigos 769 a $772^{145}$. Esses dispositivos refletiam a diretriz, advinda das Ordenações, e dos principais autores que as comentaram, conforme vistas acima. O art. 769 taxava de ilícita a cláusula pela qual o credor era autorizado a ficar com o bem dado em garantia "sem avaliação alguma, ou sendo feita a avaliação pelo mesmo credor". $\mathrm{O}$ art. 770 permitia expressamente que se avençasse o direito do credor de, diante do inadimplemento, realizar a venda do bem. $\mathrm{O}$ art. 771, por sua vez, previa que "é lícita a cláusula de ficar o credor com o penhor pelo seu justo preço", desde que esse fosse determinado, após o vencimento, por dois avaliadores juramentados e escolhidos por ambas as partes (art. 772). Em nota acrescida na terceira edição da obra, TEIXEIRA DE FREITAS vai mais longe, e sugere que:

"não é nullo porém o pacto de ficar o credor com o penhor a elle vendido por um preço certo declarado no contracto, se a dívida não for paga no tempo convencionado. Se o declarado preço não for justo, a ponto de haver lesão enorme, cabe o remédio da Ord. L.4 $4^{o}$ T. $13^{\prime \prime 146 . ~}$

\subsubsection{Código Civil de 1916.}

O Código Civil de 1916 estabelecia a proibição do pacto comissório em seu art. 765, que integrava capítulo dedicado aos direitos reais de garantia de modo geral, como introito às disciplinas específicas do penhor, da hipoteca e da anticrese. A redação da norma era a seguinte: "É nula a cláusula que autoriza o credor pignoratício, anticrético ou hipotecário, a ficar com o objeto da garantia, se a dívida não for paga no vencimento".

\footnotetext{
144 J.H. CORREA TELLES. Digesto portuguez. p. 194 (n. 1208).

${ }^{145}$ A. TEIXEIRA DE FreITAS. Consolidação das leis civis. v. I. (coleção História do Direito Brasileiro). Brasília, Senado Federal, 2003. p. 475-476.

${ }^{146}$ A. TEIXEIRA DE Freitas. Consolidação das leis civis. v. I. p. 475.
} 
Nas notas de rodapé 6 a 15 (capítulo 1), consta um relato suficientemente ilustrativo da visão que, durante a vigência do Código Civil de 1916, predominou na doutrina privatista brasileira, a respeito da proibição do pacto comissório. Destoam positivamente dessa visão média - por realizarem análises mais ricas, ainda que não tão rigorosas, do assunto - os comentários de CARVALHO SANTOS $^{147}$ e a monografia de FRAGA ${ }^{148}$.

CARvalho Santos é dos poucos que questiona a tendência de se tratar com maior complacência o pacto comissório ex intervallo. Pondera ele que, após a constituição da garantia, ou mesmo após o vencimento, a pressão que se pode colocar sobre o devedor não é por definição menor do que a teoricamente lhe afligia no momento da assunção da dívida. No mesmo excerto, esse autor apresenta contribuição que cumpre sublinhar:

"Na verdade, o pacto comissório desnatura o contrato de segurança real, por isso que estabelece uma venda condicional, ao mesmo passo que prejudica, se não inutiliza, os seus fins, por não dar lugar à concorrência de compradores, desde que, em última análise, é uma alienação ajustada a determinada pessoa"149.

CARVAlHO SANTOS é ainda, dentre os autores brasileiros consultados, quem mais se dedica a explicar os argumentos favoráveis e contrários à licitude do pacto marciano, sendo ainda dos primeiros a defender a validade, após o vencimento, da dação em pagamento do bem empenhado ${ }^{150}$. Essa permissão foi depois positivada nos parágrafos únicos dos artigos 1.365 e 1.428 do Código Civil.

Além de CARvalho SAntos, há um segundo autor brasileiro que se sobressai pela abordagem, comparativamente mais aprofundada que faz do pacto

147 J.M. Carvalho Santos. Código civil brasileiro interpretado. Principalmente do ponto de vista prático. Direito das coisas (arts. 755-862). v. X. $9^{a}$ edição. Rio de Janeiro, São Paulo, Livraria Freitas Bastos, 1964. p. 90-95.

${ }^{148}$ A. Fraga. Direitos reaes de garantia. Penhor, anticrese e hipoteca. São Paulo, Saraiva, 1933. p. 119-125.

${ }^{149}$ J.M. CARVALHO SANTOS. Código civil brasileiro interpretado. p. 91.

${ }^{150}$ J.M. CARvalho Santos. Código civil brasileiro interpretado. p. 92-95. No mesmo sentido, T. FulgenCIO. Direito real de hipoteca. p. 110-111; e C.M. DA SILVA PereIRA. Instituições de direito civil.p. 210. 
comissório. Trata-se de FrAGA, que em 1933 publicou importante obra sobre os direitos reais de garantia, acima citada. Entre os estudiosos nacionais, FRAGA é o único entre os consultados na pesquisa que aponta certas variações sob as quais o pacto comissório pode apresentar, que são (i) a autorização para que o credor venda o bem dado em garantia, por qualquer preço; (ii) a autorização para que o credor tornese titular do bem dado em garantia, por preço previamente ajustado, isto é, ajustado antes do vencimento da dívida; e (iii) a autorização para que o credor torne-se titular do bem dado em garantia, pelo preço que ele próprio vier a estimar.

É dos seletos autores, também, a identificar no pacto comissório um problema de função ou de incompatibilidade com a causa. Segundo ele, essa cláusula constitui o disfarce de uma "venda forçada e condicional que se contrapõe e inutiliza a finalidade legítima das relações de segurança real"151.

FRAGA desconstrói ainda a opinião de que, após a contratação da dívida, ou após a constituição da garantia, desapareceria a razão de ser da proibição, o que faz sob o pressuposto de que ela corresponde, simplesmente, à necessidade de proteção do devedor. $\mathrm{O}$ autor demonstra que, em se aceitando, como fundamento da proibição, a fragilidade do devedor, é falaciosa a consideração de que, uma vez obtidos os recursos do empréstimo, essa debilidade deixaria de existir. O produto do mútuo não raro é destinado ao pagamento de outras dívidas, e a proximidade do vencimento, ou o próprio vencimento, com a possibilidade de adoção de medidas coercitivas pelo credor, certamente não diminuem a posição de inferioridade do devedor, sendo mais provável que a aumentem ${ }^{152}$.

FRAGA defende a validade do pacto marciano, secundando a tradição do direito luso-brasileiro, no sentido de aceitar que o credor se torne titular do bem dado em garantia, desde que o faça "pelo justo preço", assim definido por terceiros isentos. Entende esse autor, porém, que não haveria problema em a avaliação por terceiro se dar quando da contratação da dívida ou da garantia, o que o afasta das análises estrangeiras mais recentes e mais cuidadosas (conforme vistas ao longo

${ }^{151}$ A. Fraga. Direitos reaes de garantia. p. 121. Como visto, o argumento é também defendido por L.C. PENTEADO. Direito das coisas. p. 437, já na vigência do Código Civil.

${ }^{152}$ A. FraGA. Direitos reaes de garantia. p. 122. 
deste capítulo 3). Segundo essas análises, tal avaliação deve ocorrer, necessariamente, após o vencimento, a fim de garantir sua sintonia com a realidade dos preços de mercado, que podem oscilar significativamente entre o momento da constituição da garantia e o momento do vencimento do débito. Por fim, antecipando a solução que viria a se consagrar nos parágrafos únicos dos artigos 1.365 e 1.428 do Código Civil, Fraga também postula a validade da transferência da titularidade do bem empenhado, pelo devedor ao credor, mediante venda ou dação em pagamento, o que segundo ele seria lícito tanto antes como após o vencimento.

O referido autor, no entanto, nada explica sobre o que diferenciaria uma dação em pagamento condicional - pactuada antes do vencimento - do pacto comissório propriamente dito. Nenhuma linha é destinada a justificar o porquê de a dação em pagamento do bem dado em garantia ser lícita, independentemente de qualquer avaliação do valor do bem por terceiro isento ${ }^{153}$. Fica igualmente sem resposta a questão sobre em que medida essa dação em pagamento se diferenciaria da modalidade de pacto comissório identificada pelo próprio FrAGA, como a autorização para que o credor torne-se titular do bem dado em garantia, por preço previamente ajustado. A despeito dessas contradições e incongruências, deve-se uma vez mais registrar o caráter distinto, no direito brasileiro, do esforço realizado por esse autor para melhor a compreensão do pacto comissório.

\subsubsection{Legislação extravagante: Lei n. $^{\circ} 4.728 / 65$, Lei $n .^{0} \quad 4.864 / 65$ e Decreto-lei n. ${ }^{\circ}$ 911/69.}

Durante a vigência do Código Civil de 1916, a vedação do pacto comissório se fez presente também na legislação extravagante, como se vê na Lei n. ${ }^{\circ}$ 4.864/65 e no Decreto-lei n. ${ }^{\circ} 911 / 69$.

A chamada lei do mercado de capitais - Lei n. ${ }^{\circ} 4.728 / 65$ - instituiu no direito positivo brasileiro a figura da alienação fiduciária de bens móveis em garantia. Em sua redação original, o art. 66 desse diploma estabelecia que, em caso de inadimplemento, facultava-se ao credor a venda da coisa a terceiros, aplicando-se

${ }^{153}$ A. FRAGA. Direitos reaes de garantia. p. 123-125. 
o preço da venda no pagamento do débito $\left(\$ 5^{\circ}\right)$. O $\S 7^{\circ}$ da redação original, de seu lado, reiterava a vedação do pacto comissório, nos seguintes termos: " $\$ 7^{o} \dot{E}$ nula a cláusula que autorize o proprietário fiduciário a ficar com a coisa alienada em garantia, se a dívida não fôr paga no seu vencimento.". Esses dispositivos foram sensivelmente alterados pela Lei n. ${ }^{\circ} 10.931 / 04$.

A Lei n. ${ }^{\circ}$ 4.864/65 trata de medidas de incentivo à construção civil e, ao disciplinar mecanismos de financiamento da construção de novas unidades habitacionais, prevê em seu art. 22 "a cessão fiduciária dos direitos decorrentes dos contratos de alienação das unidades habitacionais integrantes do projeto financiado". No art. $23, \S 1^{\circ}$, a mesma lei estatui que, em caso de inadimplemento, o credor pode "exercer diretamente todos os direitos decorrentes dos créditos cedidos, aplicando as importâncias recebidas no pagamento do seu crédito e nas despesas decorrentes da cobrança, e entregando ao devedor o saldo porventura apurado". A despeito desse instrumento de autossatisfação do credor, o $\S 3^{\circ}$ do referido dispositivo legal estabelece, em paralelismo com o art. 765 do Código Civil então vigente, que "É nula a cláusula que autoriza o cessionário fiduciário a ficar com os direitos cedidos em garantia, se a divida não fôr paga no seu vencimento".

Poucos anos depois, em 1969, o Decreto-lei n. 911 reformou a redação do aludido art. 66 da Lei n. ${ }^{\circ} 4.728 / 65$, com o propósito de incrementar os poderes que assistiam aos credores titulares de alienação fiduciária em garantia ${ }^{154}$. Além de prever o remédio processual da ação de busca e apreensão, esse decreto passou a determinar (art. $2^{\circ}$ ) que, em caso de mora, a venda do bem dado em garantia

\footnotetext{
${ }^{154}$ Sobre a alienação fiduciária em garantia, cf. O. GoMES. Direitos reais (atualizada por Luiz Edson Fachin). 19a edição. Rio de Janeiro, Forense, 2008. p. 386-390; e Perfil dogmático da alienação fiduciária. In: Contratos em espécie: atribuição patrimonial e garantia (organizadores Gustavo Tepedino e Luiz Edson Fachin). São Paulo, Revista dos Tribunais, 2011 (Coleção doutrinas essenciais: obrigações e contratos, v. 5). p. 475-481; J.C. MOREIRA AlVES. Da alienação fiduciária em garantia. $2^{a}$ edição. São Paulo, Saraiva, 1979. F.S. AmARAL NeTO. A alienação fiduciária em garantia no direito brasileiro. In: Contratos em espécie: atribuição patrimonial e garantia (organizadores Gustavo Tepedino e Luiz Edson Fachin). São Paulo, Revista dos Tribunais, 2011 (Coleção doutrinas essenciais: obrigações e contratos, v. 5). p. 315-333. M.N. ChALHUB. Negócio fiduciário. Alienação fiduciária. Cessão fiduciária. Securitização. $3^{\mathrm{a}}$ edição. Rio de Janeiro, Renovar, 2006. P. ReStifFe Neto e P.S. ReSTIFFE. Garantia fiduciária. $3^{a}$ edição. São Paulo, Revista dos Tribunais, 2000. Para um panorama das principais questões debatidas na jurisprudência sobre a alienação fiduciária em garantia, cf. o artigo do Des. J.G.de JACOBINA RABELLO. Alienação fiduciária em garantia. In: Contratos em espécie: atribuição patrimonial e garantia (organizadores Gustavo Tepedino e Luiz Edson Fachin). São Paulo, Revista dos Tribunais, 2011 (Coleção doutrinas e s senciais: obrigaçõ e s e contratos, v. 5). p. $339-363$.
} 
poderia ser realizada pelo credor "independentemente de leilão, hasta pública, avaliação prévia ou qualquer outra medida judicial ou extrajudicial". Não obstante tais mudanças, protetivas dos interesses dos credores, a vedação do pacto comissório continuou a constar da lei modificada, no $\$ 6^{\circ}$ do mesmo art. 66 , com a redação que lhe foi atribuída pelo mencionado Decreto-lei n. ${ }^{\circ}$ 911/69. As mais recentes modificações desse último dispositivo legal - editadas já na vigência do Código Civil, serão abordadas no capítulo 4.

\subsection{A proibição do pacto comissório no Código Civil.}

Já se aludiu, em diversas passagens deste trabalho, que a proibição do pacto comissório acha-se hoje expressa nos artigos 1.365 e 1.428 do Código Civil. Diante do que se viu até aqui, nas legislações estrangeiras, e no histórico da vedação no direito brasileiro, os principais aspectos do direito vigente a serem salientados são os seguintes: (a) a proibição é dirigida às garantias reais tradicionais - penhor, à hipoteca, à anticrese (art. 1.428) - e também à propriedade fiduciária (art. 1.365), no que é seguida a tradição legislativa formada pelas Leis n. ${ }^{\circ}$ 4.728/65 e 4.864/65 e pelo Decreto-lei n. ${ }^{\circ}$ 911/69; (b) não é feita qualquer referência ao momento da celebração do pacto, isto é, a lei parece tratar de modo indistinto o pacto comissório puro e simples, e o pacto comissório ex intervallo; (c) inexiste, também, qualquer referência ao pacto marciano, como forma de se superar a ilicitude do pacto comissório, muito menos à possibilidade de se prescindir de avaliação na hipótese de os bens serem objeto de negociação em bolsa ou mercado de balcão, ou ainda contarem com cotação confiável e publicamente disponível; e (d) admite-se, de modo franco, que após o vencimento, o devedor efetue em favor do credor a dação em pagamento do bem dado em garantia, independentemente de se tratar de relação para consumo, e independentemente, também, de vir a ser instaurado procedimento de proteção ou salvaguarda do credor (recuperação judicial ou extrajudicial) ou mesmo processo de execução coletiva (concurso civil de credores ou falência).

Os comentários ao Código Civil, de modo geral, não acrescentam muito ao quanto consta do texto da lei, nem à visão doutrinária média que 
preponderava na vigência do Código Civil de $1916^{155}$. Entre as obras brasileiras de uso e citação frequentes, a contribuição mais enriquecedora sobre o fundamento da proibição do pacto comissório é a de MONTEIRO, conforme atualizada por MALUF ${ }^{156}$. De modo aparentemente singelo, tais autores são incisivos ao sustentar que existe uma razão "de ordem técnica" para a proibição do pacto comissório, que se somaria à razão dita "de ordem moral", que é usualmente reverberada pela maioria dos autores brasileiros. Em trecho que merece transcrição, por seu caráter singular na doutrina nacional, afirmam:

"A razão de ordem técnica prende-se à ausência de preços no mercado. Inexistindo qualquer controle, fácil será ao credor alegar que o objeto oferecido em garantia não vale a soma que lhe é devida. Muito sério, pois, o perigo a que se acha exposto o devedor, por força da referida estipulação" ${ }^{157}$.

Esses são (a) os traços que conferem caráter próprio à proibição do pacto comissório no direito brasileiro; e (b) os registros cabíveis sobre o que de mais alentado se afirmou, no Brasil, sobre os seus fundamentos. Pode-se, com isso, passar ao capítulo central da tese. Nele, busca-se investigar os possíveis fundamentos dessa vedação, tendo como norte a disciplina jurídica que se extrai das leis vigentes.

\footnotetext{
${ }^{155}$ L.E. FAChIN. Comentários ao código civil (coord. Antonio Junqueira de Azevedo). v. 15. Parte especial. Do direito das coisas (arts. 1.277 1.368). São Paulo, Saraiva, 2003. p. 358-362. M.A.S. VIANnA. Comentários ao novo código civil. v. XVI. Dos direitos reais. Arts. 1.255 a 1.510 (coord. Sálvio de Figueiredo Teixeira). Rio de Janeiro, Forense, 2003. p. 532-533 e 717-718. S. VENOSA. Código civil comentado. v. XII. Direito das coisas, posse, direitos reais, propriedade. Arts. 1.196 a 1.368 (coord. Álvaro Villaça Azevedo). São Paulo, Atlas, 2003. p. 519-520. G.K.L. de OLIVEIRA. Comentários ao código civil brasileiro. v. XII (Arts. 1.277 a 1.389). Da propriedade, da superfície e das servidões (coord. Arruda Alvim e Teresa Alvim). Rio de Janeiro, Forense, 2004. p. 244-246.

${ }^{156}$ W.B. MonteIRo. Curso de direito civil. Direito das coisas. $37^{\mathrm{a}}$ edição, revista e atualizada por C.A.D. MALuF. São Paulo, Saraiva, 2003. p. 351-353. Essas ponderações são citadas e repetidas por S. VENOSA. Direitos reais. p. 472-473.

${ }^{157}$ W.B. MONTEIRO. Curso de direito civil. Direito das coisas. p. 352.
} 


\section{JUSTIFICATIVAS PARA A PROIBIÇÃo DO PACTO COMISSÓRIO NO DIREITO BRASILEIRO.}

Incumbe a este capítulo 4 apreciar de modo crítico, à luz do direito posto, os seguintes e possíveis fundamentos da proibição do pacto comissório: (a) proteção do devedor; (b) repressão à usura; (c) caráter inderrogável da via judicial como forma de execução; (d) existência de um interesse social em coibir a difusão do pacto comissório; e (e) preservação da par conditio creditorum.

\subsection{Proteção do devedor.}

Pode-se afirmar, com razoável segurança, que a proteção do devedor constituiu a razão histórica para que, no período pós-clássico do direito romano, fosse instituída a proibição do pacto comissório ${ }^{158}$. Nos períodos antigo e clássico, era permitido avençar, diante da constituição de direitos reais de garantia, o direito de o credor haver de pronto para si a titularidade do bem dado em garantia, em caso de inadimplemento do devedor; foi sob o império de Constantino que, no início do período pós-clássico, tornou-se ilícita a atribuição contratual desse direito ao credor $^{159}$.

\footnotetext{
${ }^{158}$ F.C. PONTES DE MIRANDA. Tratado de direito privado. $t$. XX. (§ 2.422). p. 28.

${ }^{159}$ A divisão cronológica da experiência jurídica romana em três períodos, que integrariam a chamada história interna do direito romano, atende à conveniência do estudo sistemático das respectivas instituições de direito privado, como nota J. C. MoREIRA ALVES. Direito romano. v. I. Rio de Janeiro, Forense, 1999. p. 1-3. Na mesma obra, o autor explica que o pacto comissório, admitido até o início do período pós-clássico, dependia de convenção expressa e específica a seu respeito. Na ausência dessa convenção, o credor não dispunha do poder jurídico de obter para si a propriedade da coisa dada em garantia, caso o devedor deixasse de adimplir a obrigação. No mesmo sentido, mas restringindo apenas ao caso do penhor (e não da hipoteca) a permissão vigente até a norma editada pelo Imperador Constantino, cf. F. MACKELDEY. Manuel de droit romain. $3^{\text {a }}$ edição. Trad. J. Beving, Bruxelles, Société Typographique Belge, 1846. p. 178 ; e M. TALAMANCA. Istituzioni di diritto romano. Milano, Giuffrè, 1990. p. 482-484. Ainda sobre o contraste entre o período clássico, em que se admitia a validade do pacto comissório, e o período pós-clássico, em que a vedação passou a vigorar, cf. P. Bonfante. Diritto romano. Ristampa a cura di Giuliano Bonfante e Giuliano Crifò. Milano, Giuffrè, 1976. p. 322-324; V. ARRANGIO-RUIZ. Istituzioni di diritto romano. $14^{\mathrm{a}}$ ed. (Ristampa). Napoli, Casa Editrice Eugenio Jovene, 2006. p. 262-268; F. SCHULZ. Derecho romano clásico. p. 395-396; P.F. GIRARD. Manuel elementaire de droit romain. $4^{\mathrm{a}}$ ed. Paris, Arthur Rousseau, 1906. p. 776-780.; A. GUARINO. Diritto privato romano. $12^{\mathrm{a}}$ ed. Napoli, Jovene, 2001. p. 754-761; e R. ZIMMERMAN. The law of obligations. Roman foundations of the civilian tradition. Oxford, Oxford University Press (Claredon Series), 1996. p. 220-227, em especial p. 224.
} 
Em que pese essa origem, a necessidade de proteção do devedor é insuficiente, no direito brasileiro, para justificar a proibição do pacto comissório. Há pelo menos três motivos para isso.

O primeiro não é exclusivo do direito brasileiro ${ }^{160}$ : corresponde ao fato de que a sanção estabelecida para o descumprimento da regra que veda o pacto comissório é a nulidade da cláusula, e não a sua anulabilidade. As normas jurídicas que visam à tutela dos contratantes que estão em posição de inferioridade para manifestar seu consentimento engendram, como consequência jurídica de seu descumprimento, a anulabilidade do negócio jurídico, ou da cláusula avençada, e não a sua nulidade $e^{161}$.

No direito brasileiro, os casos de erro, dolo, coação, estado de perigo, lesão e fraude contra credores (artigos 138 a 165 do Código Civil), bem como o caso de negócio concluído por agente relativamente incapaz, constituem hipóteses de simples anulabilidade (art. 171 do Código Civil). Como tais, podem ser confirmados pelas partes interessadas, inclusive de modo tácito, sendo que o defeito não susta a eficácia do negócio jurídico antes de ser julgado por sentença, não pode ser conhecido de ofício pelo juiz e apenas aqueles por ele prejudicados podem alegá-lo (artigos 172, 174 e 177 do Código Civil). Por outro lado, estão à base das hipóteses de nulidade, como a que acomete o pacto comissório, situações que envolvem interesses indisponíveis, insuscetíveis de posterior confirmação, e que podem ser alegadas por qualquer terceiro, e não apenas pela parte tida como diretamente prejudicada (artigos 168 e 169 do Código Civil).

\footnotetext{
${ }^{160}$ I. A. DE MATOS. O pacto comissório. p. 58-61.

${ }^{161}$ C.A. Mota PINTO. Teoria geral do direito civil. p. 610, segundo o qual: "O regime e os efeitos mais severos da nulidade encontram o seu fundamento teleológico em motivos de interesse público predominante. As anulabilidades fundam-se na infração de requisitos dirigidos à tutela de interesses predominantemente particulares". Entre os autores brasileiros, não é de todo rigoroso no trato dos conceitos, mas exprime a distinção em apreço O. GOMES. Introdução ao direito civil. 12a edição. Atualizador: Humberto Theodoro Jr. Rio de Janeiro, Forense, 1996. p. 473, no que toca à figura do ato ou negócio nulo, e p. 476, no que toca à figura do ato ou negócio anulável. Mais precisos e rigorosos são os trabalho de M.B. DE MEllo. Teoria do fato jurídico. Plano da validade. $2^{\mathrm{a}}$ edição. São Paulo, Saraiva, 1997. p. 53-55; e 107-109; e F. AMARAL. Direito civil. Introdução. p. 519, que, sobre a anulabilidade, esclarece que: "Sua razão de ser está na proteção que o direito dispensa aos interesses particulares". Ainda sobre a disciplina dos negócios nulos e anuláveis, cf. W. FLUME. El negocio jurídico. Parte general del derecho civil. Tomo segundo. $4^{\mathrm{a}}$ edição. Trad. José Maria Miguel Gonzalez e Esther Gómez Calle. Madrid, Fundacion Cultural del Notariado,1998. p. 643-701.
} 
O segundo motivo está relacionado com o primeiro, mas com ele não se confunde. O direito positivo brasileiro já prevê, na parte geral do Código Civil, ao menos duas figuras destinadas a proteger a parte contratual inferiorizada que, sob premente necessidade, por inexperiência, ou pela necessidade de salvar a si ou pessoa de sua família, assume obrigação manifestamente desproporcional ou excessivamente onerosa ${ }^{162}$. As hipóteses do estado de perigo (art. 156) e da lesão (art. 157) já atribuem os remédios cabíveis para a tutela do devedor debilitado pelas referidas circunstâncias ${ }^{163}$. Fazem-no mediante recurso, coerente, ao regime das anulabilidades. Diante disso, não faz sentido que, em uma hipótese substancialmente idêntica (necessidade de proteção do devedor vulnerável, que se vê compelido pelas circunstâncias a avençar o pacto comissório), o mesmo Código Civil, pelas mesmas razões, estabelecesse consequência jurídica diversa, qual seja, a nulidade da cláusula e não a sua mera anulabilidade. A aceitação dessa incongruência quebraria a lógica que se supõe deva presidir a disciplina legal aplicável. Pela ótica da proteção do devedor, a vedação do pacto comissório nada mais seria do que um caso especial de lesão ou estado de perigo. Mas esse caso especial - não se sabe o porquê - teria uma solução significativamente diversa de hipóteses idênticas. Teria, ademais, uma resposta da ordem jurídica mais dura e mais enérgica do que aquela cabível em situações mais graves, como é o caso do dolo e da coação, que envolvem, respectivamente, fraude e violência contra a pessoa.

A terceira razão, finalmente, diz respeito aos próprios parágrafos únicos dos artigos 1.365 e 1.428 do Código Civil. Na vigência do Código Civil de 1916, era controversa a legalidade do acordo, posterior ao vencimento, destinado a

\footnotetext{
162 É questionável a incidência das previsões sobre estado de perigo e lesão a negócios jurídicos celebrados por empresários e sociedades empresárias. Tratando-se de exercício de atividade profissional, não se pode escusar a inexperiência, de que fala o caput do art. 157 do Código Civil. No caso das sociedades empresárias, não concebe também a necessidade de salvar a si ou a pessoa de sua família, de que cuida o caput do art. 156 do Código Civil. O Código Comercial de 1850, revogado pelo Código Civil em todos os seus dispositivos com exceção apenas daqueles relativos ao direito comercial marítimo, em seu art. 220, estabelecia que: “Art. 220. A rescisão por lesão não tem lugar nas compras e vendas celebradas entre pessoas todas comerciantes; salvo provando-se erro, fraude ou simulação".

${ }^{163}$ Sobre o estado de perigo e a lesão como defeitos dos negócios jurídicos, cf. J.L. CORRÊA DE OliveIRA. A parte geral do anteprojeto de Código Civil. In: Obrigações e contratos: estrutura e dogmática (organizadores Gustavo Tepedino e Luiz Edson Fachin). São Paulo, Revista dos Tribunais, 2011 (Coleção doutrinas essenciais; v. 1). p. 169-193.
} 
transferir ao credor a propriedade do bem dado em garantia ${ }^{164}$. Os aludidos dispositivos do código vigente tornaram expressamente permitida a dação em pagamento do bem dado em garantia, se celebrada após o vencimento. Sendo assim, não se alcança, pela ótica da lei em vigor, a razão pela qual se deva proteger o devedor necessitado no momento em que a garantia é constituída, mas o débito não está vencido, e se possa deixa-lo à sua própria sorte, ou "à mercê de explorações usurárias", nos citados dizeres de PONTES DE MiRANDA, a partir do momento em que a dívida está vencida. Ao contrário do que se poderia supor pela mera leitura da lei, o vencimento da dívida sem o correspondente pagamento, pesadas as circunstâncias, pode deixar o devedor em uma posição mais vulnerável às pressões excessivas do credor, se comparada à situação do devedor no momento em que a dívida ou a garantia são constituídas. É na primeira situação, na qual o devedor já está sujeito às medidas coercitivas atribuídas ao credor, mais do que na segunda, que o devedor está mais exposto ao risco de se ver compelido a concordar com uma dação em pagamento que lhe diminua o patrimônio de modo desproporcional ao valor do débito inadimplido ${ }^{165}$. Também por esse terceiro motivo, não se sustenta, no direito brasileiro vigente, a tentativa de fundamentar a proibição do pacto comissório na necessidade de proteção do devedor.

\subsection{Repressão à usura.}

Uma segunda justificativa apontada para a vedação do pacto comissório corresponde à alegada necessidade de coibir práticas usurárias ${ }^{166}$. Um importante defensor dessa posição é ANTUNES VARELLA, que o faz com apoio nas normas do direito português ${ }^{167}$.

A repressão à usura, ao contrário do que se poderia imaginar, não constitui peculiaridade dos países do direito continental europeu e da América

\footnotetext{
${ }^{164}$ C. Bevilacqua. Código Civil dos Estados Unidos do Brasil. v. III. p. 1229 (comentário ao art. 765): "O pacto comissório não pode ser estipulado no momento de ser dada a garantia real, nem posteriormente". Em sentido contrário, F.C. PONTES DE MIRANDA. Tratado de direito privado. t. XX. (§ 2.422). p. 29.

${ }_{165}$ J.M. CARVALHO SANTOS. Código civil brasileiro interpretado. p. 90-95.

${ }^{166}$ C.M. BIANCA. Il divieto del patto comissorio. p. 210; I. A. DE MATOS. O pacto comissório. p. 6264.

${ }^{167}$ J.M. ANTUNES VARELLA. Das obrigações em geral. v. II. p. 555.
} 
Latina, mais permeáveis que estiveram às influências do direito canônico e da Igreja Católica de modo geral. Tem-se notícia de que, desde a época da independência e até muito recentemente, havia normas proibitivas da usura nos Estados Unidos da América, algumas inclusive com reflexos criminais ${ }^{168}$. Previstas nas legislações dos Estados norte-americanos, tais normas foram objeto de apreciação pela Suprema Corte norte-americana em 1978 (Marquette National Bank of Minneapolis v. First Omaha Service Corporation, 439 U.S. 299 (1978)). O litígio versava, nesse precedente, sobre qual seria o limite aplicável para a taxa de juros bancária, se aquele vigente no domicílio do cliente, ou no Estado em que o banco tivesse sua sede. A Suprema Corte norte-americana decidiu, no caso, à luz da disciplina federal da atividade bancária, que eram irrelevantes as disposições da lei do domicílio do cliente tomador do empréstimo. Por consequência, os bancos autorizados a funcionar pelas autoridades federais podiam cobrar os juros que fossem permitidos no Estado em que estivessem constituídos. Essa decisão gerou uma espécie que "guerra regulatória" entre os diferentes Estados norte-americanos, que passaram a tolerar taxas de juros bancárias cada vez mais altas, com o objetivo de atrair para seus territórios sedes de instituições financeiras. Em resposta, os Estados que experimentaram o abandono das sedes das instituições financeiras também passaram a ter postura condescendente com o limite das taxas de juros. Em 1965, o teto para a cobrança de juros no Estado do Arizona era de 18\% anuais; em 2007, esse número era de $460 \%$; há relato também de que certos estados norte-americanos acabavam por manipular a legislação de repressão à usura, de modo que o número parecesse baixo, para fins políticos e eleitorais, mas na prática fosse alto o suficiente para satisfazer os interesses empresariais das instituições financeiras ${ }^{169}$. Foi a partir de meados dos anos 1980 que a matéria sofreu, nos Estados Unidos, forte movimento de desregulamentação. Embora ainda existam leis estaduais contendo normas limitadoras das taxas de juros praticadas em empréstimos bancários, de modo geral predomina, hoje, um quadro de abolição dessas normas ${ }^{170}$. A limitação das taxas de

\footnotetext{
${ }^{168}$ E. WARREN e J.L. WeStBroOK. The law of debtors and creditors. Text, cases and problems. Austin, Boston, Chicago, New York, The Netherlands, Wolters Kluwer, 2009. p. 13-14.

${ }^{169}$ E. WARREN e J.L. WESTBROOK. The law of debtors and creditors. p. 14.

${ }^{170}$ E. WARREN e J.L. WESTBROOK. The law of debtors and creditors. p. 113-115, a respeito da grave situação de excesso de endividamento experimentada por grande parte dos consumidores e pessoas físicas norte-americanas em geral, afirmam: "Throughout the twentieth century and into the twentyfirst, the consumer credit industry has expanded and grown more profitable by steadily extending credit solicitations to include people who were once considered too risky for such loans. With the
} 
juros, inclusive bancárias, de todo modo, não é estranha ao direito norte-americano. Após a crise financeira de 2008, voltaram a ganhar força, nos Estados Unidos, os argumentos favoráveis a uma maior e mais intensa regulação das operações de crédito, em especial do crédito ao consumidor ${ }^{171}$. Nesse contexto mais recente, merecem registro, em especial, a promulgação, em 2010, do Dodd-Frank Wall Street Reform and Consumer Protection Act e a criação da Consumer Financial Protection Bureau, agência especialmente devotada à regulação e fiscalização das operações de crédito ao consumidor.

No Brasil, a Emenda Constitucional n. ${ }^{\circ} 40$, de 29 de maio de 2003, modificou a redação do art. 192 da Constituição Federal e excluiu do dispositivo, dentre outros, o seu anterior $\$ 3^{\circ}$, que buscava limitar as taxas reais de juros a $12 \%$ ao ano $^{172}$. Permanecem hoje, no direito brasileiro, como regras proibitivas da usura aquelas constantes: (a) do Decreto n. ${ }^{\circ} 22.626$, de 7 de abril de 1933 ("Lei da Usura"), em especial seus artigos $1^{\circ}, 2^{\circ}$ e 13); (b) da Lei n. ${ }^{\circ} 1.521$, de 26 de dezembro de 1951 ("Leis dos Crimes contra a Economia Popular"), que qualifica a usura como delito no seu art. $4^{\mathrm{o}}$; e (c) da Medida Provisória n. ${ }^{\circ}$ 2.172-32, de 23 de agosto de 2001, ainda em vigor e em trâmite no Congresso Nacional, por ser anterior à Emenda Constitucional n. ${ }^{\text {o }} 32$, de 11 de setembro de $2001^{173}$.

effective abolition of usury laws, the industry is very profitable and attracted huge amounts of investment from the capital markets, increasingly secured by pools of consumer debt (a process called securitization). Nonetheless, the industry has been increasingly concerned about the rise in consumer bankruptcies and has not been shy in demanding that Congress pass tougher laws". Em tradução livre: "Durante o século XX e início do XXI, o mercado de crédito ao consumidor expandiu e se tornou mais rentável mediante a concessão contínua de financiamentos a pessoas a quem antes se considerava muito arriscado emprestar. Com a abolição, na prática, das leis de repressão à usura, o mercado se tornou muito rentável e passou a atrair grandes investimentos vindos do mercado de capitais, crescentemente garantidos por carteiras de empréstimos concedidos a consumidores (um processo conhecido como securitização). Apesar disso, é crescente a preocupação nesse mercado com o aumento da insolvência dos consumidores e os agentes não se acanham em solicitar ao Congresso que aprove leis mais duras contra os devedores inadimplentes".

${ }^{171}$ Cf. o interessante artigo de O. BAR-GILL and E. WARREN. Making credit safer. University of Pennsilvania Law Review. v. 157. 2008. P. 101-201.

${ }^{172}$ As referências feitas aos juros terão sempre por objeto os chamados juros remuneratórios.

173 As disposições da Lei da Usura e da Lei dos Crimes contra a Economia Popular vigoram há décadas no Brasil e são bastante conhecidas e invocadas com frequência nos tribunais e na doutrina. É despiciendo, assim, transcrevê-las neste trabalho. O mesmo não acontece, porém, como as disposições da mencionada Medida Provisória, que embora vigore como lei há praticamente 10 anos, não costuma receber muita atenção, seja no foro, seja na doutrina. Não é ocioso transcrever os respectivos artigos $1^{\circ}$ a $4^{\circ}$, que assim prescrevem: “Art. $\mathbf{1}^{\circ}$ São nulas de pleno direito as estipulações usurárias, assim consideradas as que estabeleçam: I - nos contratos civis de mútuo, taxas de juros superiores às legalmente permitidas, caso em que deverá o juiz, se requerido, ajustá-las à medida legal ou, na hipótese de já terem sido cumpridas, ordenar a restituição, em dobro, da quantia paga em excesso, com juros legais a contar da data do pagamento indevido; II-nos negócios jurídicos não 
Sobre a interpretação dessas regras, o STF e o STJ, desde antes da edição da referida Medida Provisória, já haviam sedimentado o entendimento de que a limitação da taxa de juros não era aplicável aos contratos de empréstimo celebrados no âmbito do Sistema Financeiro Nacional ${ }^{174}$. A citada Medida Provisória, em seu art. $4^{\circ}$, elimina qualquer caráter reprovável na cobrança de juros em taxas superiores ao dobro da taxa legal nos casos em que os mutuantes são instituições financeiras. Seja qual for a diretriz adotada pela ordem jurídica sobre a limitação das taxas de juros, no sentido de adotá-la ou não, é difícil compreender e explicar, em termos valorativos e racionais, o porquê de regras tão duras, proibitivas da usura, endereçadas à generalidade dos particulares, e a completa ausência de qualquer caráter censurável na exata e mesma conduta, quando praticada por instituições financeiras. Não vai nisso qualquer juízo moral, político, ideológico, não raramente maniqueísta, em relação às práticas das instituições financeiras. O que se verifica objetivamente - é uma falta de coerência valorativa da ordem jurídica brasileira em relação à cobrança de juros, que passa da licitude à ilicitude segundo um critério apenas subjetivo, isto é, conforme o mutuante seja ou não instituição financeira,

disciplinados pelas legislações comercial e de defesa do consumidor, lucros ou vantagens patrimoniais excessivos, estipulados em situação de vulnerabilidade da parte, caso em que deverá o juiz, se requerido, restabelecer o equilíbrio da relação contratual, ajustando-os ao valor corrente, ou, na hipótese de cumprimento da obrigação, ordenar a restituição, em dobro, da quantia recebida em excesso, com juros legais a contar da data do pagamento indevido. Parágrafo único. Para a configuração do lucro ou vantagem excessivos, considerar-se-ão a vontade das partes, as circunstâncias da celebração do contrato, o seu conteúdo e natureza, a origem das correspondentes obrigações, as práticas de mercado e as taxas de juros legalmente permitidas. Art. $2^{o}$ São igualmente nulas de pleno direito as disposições contratuais que, com o pretexto de conferir ou transmitir direitos, são celebradas para garantir, direta ou indiretamente, contratos civis de mútuo com estipulações usurárias. Art. $3^{\circ}$ Nas ações que visem à declaração de nulidade de estipulações com amparo no disposto nesta Medida Provisória, incumbirá ao credor ou beneficiário do negócio o ônus de provar a regularidade jurídica das correspondentes obrigações, sempre que demonstrada pelo prejudicado, ou pelas circunstâncias do caso, a verossimilhança da alegação. Art. $4^{o}$ As disposições desta Medida Provisória não se aplicam: I - às instituições financeiras e demais instituições autorizadas a funcionar pelo Banco Central do Brasil, bem como às operações realizadas nos mercados financeiro, de capitais e de valores mobiliários, que continuam regidas pelas normas legais e regulamentares que lhes são aplicáveis; II - às sociedades de crédito que tenham por objeto social exclusivo a concessão de financiamentos ao microempreendedor; III - às organizações da sociedade civil de interesse público de que trata a Lei $n^{\circ}$ 9.790, de 23 de março de 1999, devidamente registradas no Ministério da Justiça, que se dedicam a sistemas alternativos de crédito e não têm qualquer tipo de vinculação com o Sistema Financeiro Nacional.".

${ }^{174} \mathrm{Na}$ jurisprudência do STF, o entendimento dominante foi estabelecido no enunciado da Súmula n. ${ }^{\circ}$ 586, segundo o qual: "As disposições do Decreto 22.626/33 não se aplicam às taxas de juros e aos outros encargos cobrados nas operações realizadas por instituições públicas ou privadas que integram o Sistema Financeiro Nacional". Na jurisprudência do STJ, o entendimento dominante não é discrepante, conforme se infere pelo enunciado da Súmula n. ${ }^{\circ} 283$ : "As empresas administradoras de cartão de crédito são instituições financeiras e, por isso, os juros remuneratórios por elas cobrados não sofrem as limitações da Lei de Usura.". 
pública ou privada. Em outras palavras, não parece ser possível identificar uma correlação lógica entre a reprovabilidade da conduta e a circunstância de ser ela praticada por instituição financeira ${ }^{175}$.

Não são aqui ignoradas: (a) a importância decisiva do aspecto subjetivo para a caracterização da atividade financeira propriamente $\operatorname{dita}^{176}$; (b) as características próprias desta última, nem (c) a relevância da intermediação financeira para o funcionamento da economia. Disciplinada por lei complementar (Lei n. ${ }^{\circ}$ 4.595, de 31 de dezembro de 1964), a atividade financeira tem a peculiaridade de resultar no fenômeno da chamada moeda escritural, cujo efeito é multiplicador dos recursos financeiros recebidos em depósito ${ }^{177}$. É mais do que justificada, considerando a necessidade de tutela da poupança do público investidor e a sua relevância para o funcionamento da economia como um todo, a existência de normas jurídicas próprias e especificamente endereçadas às instituições financeiras. Não obstante essas circunstâncias, o que se continua a não conseguir estabelecer é um nexo coerente que permita justificar a licitude de uma determinada taxa de juros remuneratórios conforme ela seja cobrada por uma instituição financeira, no curso de sua atividade, ou por um particular, no âmbito de um negócio jurídico isolado ou mesmo no âmbito de uma atividade empresarial que não seja financeira.

\footnotetext{
${ }^{175}$ Este trabalho não tem por objeto analisar a racionalidade da proibição da usura. Todavia, a questão da limitação da cobrança de juros aparece como um tema incidental, já que corresponde a uma das justificativas normalmente apontadas para a proibição do pacto comissório. A esse respeito, considerando: (a) que os juros nada mais são do que o "preço" da disponibilidade de recursos financeiros (sobre a taxa de juros como o retorno esperado de um ativo financeiro, na linguagem econômica, cf. P. SAMUELSON e W. NORDHAUS. Economics. 14 $4^{\mathrm{a}}$ edição. New York, MacGraw-Hill, 1992. p. 270; juridicamente, os juros representam frutos civis do crédito que remuneram a privação que o credor experimenta em relação à soma de dinheiro emprestado, cf. A. VON TuHR. Tratado de las obligaciones. t. I. Trad. W. Roces. Madrid, Reus, 1999. p. 46); (b) que não existe, como regra geral, uma limitação ao preço de compra das mercadorias oferecidas em mercado; e (c) que a cobrança de taxas superiores ao dobro da taxa legal não é de modo algum reprovável quando feita profissionalmente, pelas instituições financeiras, é de se indagar qual o sentido de manter a proibição apenas para a generalidade dos particulares, tal como ocorre hoje no direito brasileiro. Se ninguém é proibido de comprar ou vender mercadorias por preços superiores aos de mercado, por que deveria ser proibido de "comprar" ou "vender" disponibilidade monetária por preços superiores aos de mercado? Essa pergunta, cumpre esclarecer, é apenas uma provocação. Ela não reflete uma convicção de que tenham sido, ou de que são descabidas as normas que buscam reprimir a usura. Quer-se chamar a atenção, apenas, para a necessidade de se perquirir com franqueza as razões últimas que informam, ou deveriam informar, as normas de repressão à usura.

${ }^{176}$ Cf. L.G.P.B. LEÃES. O leasing é uma operação financeira? Revista de direito mercantil, industrial, econômico e financeiro. n. 35. p. 11-24. 1979.

177 J.T. DE ChIARA. Moeda e ordem jurídica. p. 82-83: "Apenas uma parte do total dos depósitos é conservado como encaixe para atender saques, e, o remanescente, instrumenta a concessão de créditos. A partir de uma quantidade determinada de moeda recebida em depósito, opera-se o efeito multiplicador nos registros contábeis dos bancos".
} 
Ainda que se tome por premissa o caráter geralmente censurável da usura no direito brasileiro, tampouco parece fazer sentido qualificar a proibição do pacto comissório como uma continuação, complemento ou extensão da proibição de se pactuar juros acima do teto legal. É verdade que o pacto comissório pode, em princípio, acobertar a cobrança de juros superiores aos admitidos pela lei. Isso acontecerá sempre que o valor de mercado do bem objeto da garantia corresponder ao valor do principal do empréstimo acrescido dos juros excessivos. Ao se tornar automaticamente proprietário do bem objeto do penhor, da anticrese ou da hipoteca, por ocasião do inadimplemento, o credor pode se apropriar do valor do principal acrescido dos juros superiores aos admitidos.

Essa, todavia, é uma circunstância de fato, acidental, e de nenhuma forma necessária ou inerente à estrutura jurídica do pacto comissório. Ela decorre da própria contratação e cobrança dos juros usurários e não das características do pacto comissório. É perfeitamente possível que o valor de mercado do bem objeto da garantia não ultrapasse o valor do principal somado aos juros legalmente convencionados. Mesmo nesse caso, inexistiria em princípio fundamento legal para que se tomasse como lícito o pacto comissório avençado em tais termos ${ }^{178}$. A não ocorrência de juros superiores aos admitidos pela lei, no caso concreto, não é tomada pela lei vigente como uma excludente da ilicitude do pacto comissório. Ainda que se admitisse a existência de uma presunção a esse respeito, ela versaria sobre uma questão de fato, e deveria assim admitir prova em contrário, o que não se verifica.

Além disso, há outras figuras jurídicas lícitas que - tanto quanto o pacto comissório - podem se prestar à cobrança de juros usurários, como é o conhecido caso da compra e venda com pacto adjeto de retrovenda (artigos 505 a 508 do Código Civil). Nem por isso a compra e venda com pacto de retrovenda é de antemão tida por peremptoriamente nula no direito brasileiro, como é o pacto

\footnotetext{
178 Note-se, novamente, que os autores portugueses anteriores à codificação de 1867 admitiam a licitude do pacto comissório nos casos em que ficasse demonstrada a inexistência de usura e adequação entre o preço da coisa e o valor da dívida, considerados os juros permitidos. Conforme nota I. A. DE MATOS. O pacto comissório. p. 46, esse raciocínio seria explicitamente seguido por autores como P.J. Mello Freire, M.A.S. LobÃO, J. H. CORRÊA TElleS e M.A. COElHO DA RoCHA. Sobre os trabalhos desses dois últimos autores, e a disciplina prevista nas Ordenações, cf. item 3.2.1.
} 
comissório. Não há, desse modo, nenhuma relação absolutamente constante e necessária entre a celebração do pacto comissório e a cobrança de juros usurários. Considerada a sua estrutura jurídica, o pacto comissório pode perfeitamente ser avençado no âmbito de contrato de empréstimo cujos juros sejam condizentes com os limites legais aplicáveis. E essa última circunstância, nos termos do Código Civil, não afasta a incidência das regras contidas nos artigos 1.365 e 1.428. Logo, não se pode qualificar a vedação do pacto comissório como uma simples extensão da proibição da usura.

Ademais, se a previsão de nulidade do pacto comissório estivesse forçosamente atrelada à proibição da usura, a consequência lógica disso seria que, no direito brasileiro, a celebração de pactos comissórios em benefício de instituições financeiras deveria ser igualmente lícita. Se as instituições financeiras não são alcançadas pela proibição da usura, e a vedação do pacto comissório servisse à prevenção de práticas usurárias, não haveria razão para que as instituições financeiras não pudessem se valer de licitamente do pacto comissório. Essa conclusão, porém, não parece ter respaldo no direito positivo ${ }^{179}$.

Por fim, o suposto fundamento da repressão à usura não explica a licitude, no direito brasileiro, da dação em pagamento do bem dado em garantia, celebrada após o vencimento da dívida. Se a transferência da propriedade da coisa objeto de penhor, anticrese ou hipoteca permite ao credor se apropriar de juros usurários, isso pode ocorrer tanto antes como após o vencimento da obrigação. O recurso à dação em pagamento em nada altera esse risco. A repressão à usura, portanto, não fornece uma explicação aceitável nem para o caput, nem para os parágrafos únicos, dos artigos 1.365 e 1.428 do Código Civil.

Pelos argumentos até aqui expendidos, conclui-se que o fundamento adequado para a vedação do pacto comissório no direito brasileiro não reside na repressão à usura ${ }^{180}$. Do contrário, haveria uma inadequação entre meios (proibição

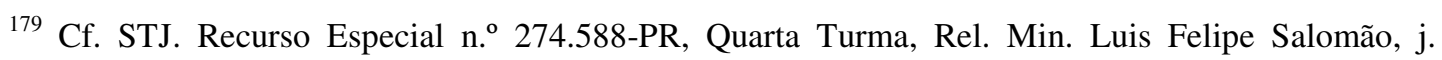
19.03.2009, p. DJe em 30.03.2009, que de modo expresso aplica a norma do art. 765 do Código Civil de 1916 a mútuo celebrado por instituição financeira.

${ }^{180}$ Por razões distintas, ligadas ao direito português (no qual o negócio usurário é anulável, e não nulo), I. A. DE MATOS alcança conclusão semelhante (O pacto comissório. p. 64.). 
do pacto comissório) e fins (proibição da usura). É perfeitamente possível que um pacto comissório não contemple a prática de usura; e há outras formas de praticar a usura que prescindem do pacto comissório e nem por isso são de antemão tidas por nulas (v.g., compra e venda com pacto de retrovenda). Do mesmo modo, se o valor de mercado do bem dado em garantia permite ao credor, ao se tornar o seu titular, receber o principal acrescido de juros superiores aos legalmente admitidos, isso pode ocorrer tanto antes como após o vencimento, inclusive no âmbito da dação em pagamento de que cuidam os parágrafos únicos dos artigos 1.365 e 1.428 do Código Civil.

\subsection{Caráter inderrogável da via judicial como forma de execução.}

O terceiro dos possíveis fundamentos da proibição do pacto comissório é invocado com menos frequência. Mas merece atenção detida. Desenvolvido essencialmente por BETTI ${ }^{181}$, e sustentado também por CARNEVALI ${ }^{182}$, ele guarda relações com a interdição da chamada justiça de mão-própria. De acordo com esse argumento, permitir que o credor tenha a si transferida a propriedade da coisa dada em garantia, pelo tão só advento do inadimplemento, corresponderia a uma forma de autotutela ou execução privada, destituída do crivo do processo judicial. Isso não seria admissível, diante do monopólio da atividade processual executiva pelo Estado. Daí BETTI defender que a proibição do pacto comissório incide não apenas nos casos de penhor e anticrese (expressamente previstos no direito positivo italiano da época), mas em todas as situações em que uma posição jurídica funciona como garantia. É o caso do direito de retenção, discutido na decisão da Corte de Apelação de Bologna que é analisada no artigo citado. O mesmo autor sustenta que a vedação do pacto comissório corresponderia à manifestação de um princípio geral, segundo o qual seria ilícita a sujeição do devedor a um poder de autotutela e autossatisfação do credor $^{183}$. Ainda no mesmo artigo, pouco mais à frente, BETTI disseca com percuciência a tensão inerente à ratio iuris da proibição do pacto comissório. Não se cuidaria, segundo ele, de impedir um resultado, que seria o

\footnotetext{
${ }^{181}$ E. BETTI. Su gli oneri. p. 689 a 715.

${ }^{182}$ U. CARneVAli. Patto comissório (voce). p. 501

${ }^{183}$ E. BETTI. Su gli oneri. p. 699.
} 
enriquecimento injustificado do credor, mas de coibir um meio, que seria a autotutela ou a satisfação coativa de direitos sem a intermediação do Estado-Juiz ${ }^{184}$.

Diferentemente da tutela do devedor, ou da proibição da usura, esse possível fundamento é o primeiro, dentre os até aqui testados, capaz em princípio de justificar a sanção de nulidade imposta ao pacto comissório, pois envolve a tutela de interesses indisponíveis. É o primeiro, também, que permite antever uma fundamentação compatível com o fato de que, após o vencimento, é lícita a dação em pagamento do bem dado em garantia. Como essa dação em pagamento é fruto de novo consentimento, manifestado pelo devedor após o inadimplemento, ela corresponderia a um modo de extinção consensual do débito, em oposição à satisfação coativa e automática, que estaria a ser censurada pela proibição do pacto comissório $^{185}$.

Outro ponto relevante, relacionado a esse argumento, é a conexão que ele estabelece entre dois sentidos distintos do termo garantia, identificados no início da exposição (capítulo 1, nota 2). Uma garantia (no sentido de reforço do vínculo obrigacional) acompanhada de pacto comissório permite a deflagração e realização imediata da garantia enquanto elemento da relação jurídica obrigacional, entendida como meio coercitivo adotado para a satisfação do interesse do credor. $\mathrm{O}$ pacto comissório, por essa ótica, realmente representaria, se lícito fosse, uma forma de execução senão equivalente, ao menos bastante semelhante à autotutela, ou à justiça de mão-própria. Seria essa uma razão determinante ou suficiente, no direito positivo brasileiro, para fundamentar a proibição do pacto comissório, sancionada que é por nulidade?

\footnotetext{
${ }^{184}$ E. BETTI. Su gli oneri. p. 705. Entende-se melhor o pensamento de BETTI ao se ler o texto do art. 1884 do código civil italiano de 1865, que estava vigente à época em que o artigo foi escrito. Dizia o dispositivo: "1884. Il creditore non può disporre del pegno pel non effettuato pagamento: ha però il diritto di far ordinare giudizialmente, che il pegno rimanga presso di lui pagamento, e fino ala concorrenza del debito secondo la stima da farsi per mezzo di periti, oppure che sia venduto all'incanto. E nullo qualunque patto, il quale autorizza il creditore ad apropriarsi il pegno o a dispore senza le formalità sopra stabilite". Em tradução livre: " 1884 . O credor não pode dispor do penhor pela não realização do pagamento; tem todavia o direito de fazer ordenar judicialmente que o penhor fique vinculado ao seu pagamento, e a fim de concorrer à satisfação do débito segundo a avaliação a ser feita por peritos, ou para que seja vendido em leilão. É nulo qualquer pacto que autorize o credor a se apropriar do penhor ou a dele dispor sem as formalidades acima estabelecidas".

${ }^{185}$ Em contraste com essa argumentação, cabe notar que o pacto comissório - avençado, antes do vencimento - pode ser tão consensual quanto a dação em pagamento posterior ao vencimento.
} 
Pela importância desse argumento para a tese, consta a seguir uma tentativa de explorar com minudência as diferentes formas de execução ou de realização da garantia das relações jurídicas que, no Brasil, ocorrem à margem do processo civil. O objetivo desse exercício é o de verificar se estaria presente, em nossa legislação, o alegado princípio geral que, segundo BETTI, proscreveria mecanismos contratuais de autotutela ou autossatisfação do credor e, por isso, poderia justificar a previsão de nulidade do pacto comissório.

\subsubsection{Jurisdição sem Judiciário?}

“O paradigma, que antes era o da lei, passou a ser o do juiz e, agora, é o da solução rápida do caso concreto. Hoje, estamos fugindo do juiz. Essa fuga não é um problema do Judiciário; ele deve decidir o que é da sua missão, da sua vocação, que é o conflito real, o 'caso difícil', que exige ponderação. Mas o juiz é um julgador e, quando não há necessidade desse julgador, não é preciso o juiz. Nesse sentido, há uma fuga do juiz." 186

Essas palavras foram proferidas, por um importante privatista, com o objetivo de apontar uma profunda defasagem que está impregnada no Código Civil. O projeto que deu origem ao Código Civil, com efeito, data da primeira metade dos anos $1970^{187}$, época muito próxima àquela da elaboração do atual Código de Processo Civil (Lei n. ${ }^{\circ}$ 5.869, de 11 de janeiro de 1973), cujo projeto veio a lume em meados de $1972^{188}$. Embora tenha por missão servir de "eixo do direito privado" 189

\footnotetext{
186 A. JUNQUEIRA DE AZEVEDO. Insuficiências, deficiências e desatualização do projeto de Código Civil (atualmente, código aprovado) na questão da boa-fé objetiva nos contratos. In: Ensaios $e$ pareceres de direito privado. São Paulo, Saraiva, 2004. p. 148-158 (em especial, p. 156).

187 O projeto de Código Civil que acabou por se converter na Lei n. ${ }^{\circ}$ 10.406/02 começou a ser elaborado em 1969 (ou seja, rente no tempo ao recrudescimento da ditadura militar decorrente do Ato Institucional ${ }^{\circ}{ }^{\circ}$ 5), tendo o resultado dos trabalhos da comissão sido submetidos ao então Ministro da Justiça Armando Falcão em 1975. Versões preliminares do projeto foram publicadas em 1972 e 1974. Sobre essa cronologia, cf. GERSON L. C. BRANCO. Função social dos contratos - interpretação à luz do Código Civil. São Paulo, Saraiva, 2009. p. 122-150; e J.C. MOREIRA AlveS. A parte geral do projeto de Código Civil brasileiro. São Paulo, Saraiva, 1984.

${ }^{188}$ Cf. Exposição de motivos da Lei n. ${ }^{\circ}$ 5.869/73.
} 
para a sociedade brasileira das primeiras décadas do século XXI, o Código Civil de 2002 tem uma "idade mental" cerca de trinta anos atrasada, para dizer o mínimo. Se considerarmos que, em larga medida, a maior inspiração do Código Civil brasileiro foi o Código Civil italiano de 1942, bem como a doutrina que lhe seguiu, não seria exagerado dizer que esse "atraso mental" é de algo como sessenta anos.

No campo do processo civil, a circunstância de o código ter sido posto em vigência em momento contemporâneo ao da sua elaboração permite que seja percebida com maior clareza essa falta de sintonia com as exigências do tempo presente. É o que demonstram as diversas iniciativas de reformas do Código de Processo Civil que surgiram no começo da década de $1990^{190}$ e que têm se estendido até os últimos anos ${ }^{191}$. Outra prova disso é a proposta ainda mais recente de elaboração de um novo Código de Processo Civil ${ }^{192}$.

Os dois projetos, o do Código Civil de 2002 e o do Código de Processo Civil de 1973, foram coevos. Ambos tiveram sua gestação no seio de um regime político autoritário, por juristas que inegavelmente detinham a confiança do governo da ocasião e que, por terem abraçado sem grandes rodeios as tarefas que se lhes apresentavam, presume-se detinham também com esse mesmo regime certa identidade de propósitos. Não é descabido trabalhar, portanto, com a hipótese de que há caracteres comuns nas concepções gerais adotadas por ambos os diplomas e semelhanças na delimitação do papel do Estado na organização da sociedade e na solução dos conflitos inerentes ao seu funcionamento.

Os parágrafos que seguem pretende tratar - sob a ótica combinada do direito privado e do processo civil - de um desses traços comuns, pertinentes às premissas ínsitas aos dois códigos. Trata-se da atribuição excessiva de competências, poderes e prerrogativas ao Estado-juiz, cujo papel na resolução dos

\footnotetext{
189 A expressão é de M. REAlE, na Exposição de Motivos do Código Civil. Diário do Congresso Nacional (Seção I), Suplemento, 14-9-1983. p. 114.

${ }^{190}$ São exemplos dessas primeiras iniciativas as Leis $n .^{\circ} 8.950,8.951,8.952$ e 8.953 , todas de 14 de dezembro de 1994.

${ }^{191}$ São exemplos dessas iniciativas mais recentes as Leis n. ${ }^{\circ} 11.232$, de 23 de dezembro de 2005 e 11.382, de 7 de dezembro de 2006.

${ }^{192}$ A comissão foi instituída pelo Ato da Presidência do Senado Federal n. ${ }^{\circ}$ 379, de 2009.
} 
conflitos é, de certo modo, superestimado. Em relação ao Código Civil, já se afirmou com propriedade que:

"o Projeto [hoje código vigente], elaborado essencialmente entre 1969 e 1972, foi feito de cima para baixo, no tempo do Estado forte, e exige inutilmente a presença do juiz togado em inúmeras situações ( $p$. ex., para declaração de resolução de contrato, quando isso não é necessário, como na quebra antecipada do contrato; para algumas hipóteses de anulação por vício de vontade; para conversão de união estável em casamento; para alteração de pacto antenupcial, etc.)"193; $(\ldots)$

"As pessoas estão fugindo da estrutura do Judiciário, própria do paradigma anterior. As escolhas, hoje, consistem em tipos mais expeditos de solução. O Projeto de Código Civil [hoje código vigente] infelizmente volta a insistir na presença do juiz para muita coisa inútil, como alguns casos de anulação e rescisão contratual. $O$ Projeto [hoje código vigente] está no paradigma do Estado inchado" ${ }^{, 194}$.

A fim de confrontar o argumento de BETTI sobre o fundamento da proibição do pacto comissório com o direito positivo brasileiro, cumpre analisar as diferentes situações em que a realização da garantia da relação jurídica, ou da garantia de um crédito, por força de lei, podem ocorrer sem qualquer participação do Poder Judiciário.

Há uma forte resistência, maior na doutrina do que na jurisprudência ${ }^{195}$, em aceitar a realização extrajudicial da garantia das relações jurídicas de direito privado. Ao lado dessa recalcitrância, existe também certa dificuldade de situar teoricamente essas formas de satisfação coercitiva do credor que

193 A. JUNQUEIRA DE AZEVEDO. O direito pós-moderno e a codificação. In: Ensaios e pareceres de direito privado. São Paulo, Saraiva, 2004. p. 55-63 (em especial p. 61).

${ }^{194}$ A. JUNQUEIRA DE AZEVEDO. Insuficiências, deficiências e desatualização do projeto de Código Civil (atualmente, código aprovado) na questão da boa-fé objetiva nos contratos. In: Ensaios $e$ pareceres de direito privado. São Paulo, Saraiva, 2004. p. 148-158 (em especial p. 156).

${ }^{195}$ Cf. E. H. O. YoshiKAWA. Execução extrajudicial e devido processo legal. São Paulo, Atlas, 2010. 
ocorrem à margem do Poder Judiciário e do processo civil, e de concatená-las com os conceitos fundamentais de jurisdição e de monopólio do Estado na atuação da chamada sanção civil. Se o processo de execução constitui "expressão autêntica do fenômeno jurisdicional" ${ }^{, 196}$ e a chamada jurissatisfação é espécie de tutela jurídica processual $^{197}$, como admitir que fiquem a cargo do interessado, de terceiros particulares, ou simplesmente fora das mãos do Estado-juiz, as atividades cruciais de imposição da sanção civil, que estão na base da qualificação do direito processual como ramo do direito público ${ }^{198}$ ? A tutela jurisdicional - e por consequência o conceito de jurisdição - são usualmente definidos sob o espectro das chamadas formas de heterocomposição, em contraposição, portanto, com os modos de auto composição e autotutela; daí a estreita correlação, usualmente apontada, entre o chamado caráter substitutivo da jurisdição e o seu monopólio pelo Estado ${ }^{199}$. Nesse quadro, as hipóteses de realização forçada do comando jurídico fora do processo são vistas como "casos verdadeiramente extraordinários" $" 200$. Como conciliar o caráter substitutivo da jurisdição e o seu monopólio pelo Estado com os casos, mais frequentes do que por vezes se supõe, de realização da garantia da relação jurídica sem a participação do Estado-juiz?

Para oferecer resposta a essa questão, será elaborado um inventário não exaustivo de hipóteses, previstas na legislação vigente, em que a deflagração da garantia da relação jurídica, ou a realização da sanção civil, ocorre sem a participação do Poder Judiciário, e sem a instauração de relação jurídica processual $^{201}$. O primeiro objetivo desse inventário é o de demonstrar que esses casos são numerosos, e por demais difundidos, para que sejam tratados como excepcionais. O segundo objetivo é o de aplacar a resistência que não raramente é manifestada contra uma eventual ampliação das hipóteses de execução que poderiam

\footnotetext{
${ }^{196}$ OvíDIO B. DA Silva. Ação de imissão de posse. $2^{\text {a }}$ edição. São Paulo, Revista dos Tribunais, 1997. p. $18-21$.

${ }^{197}$ C. NEves. Estrutura fundamental do processo civil. Tutela jurídica processual, ação, processo e procedimento. Rio de Janeiro, Forense, 1997. p. 36-37.

${ }^{198}$ E. T. Liebman. Processo de execução. São Paulo, Saraiva, 1946. p. 9-17 e, em particular, p. 69.

199 C. R. Dinamarco. Instituições de direito processual civil. v. I. $6^{\text {a }}$ edição. São Paulo, Malheiros, 2009. p. 107-128. e OvíDIO B. DA SILVA. Curso de processo civil. v. 1. $4^{\mathrm{a}}$ edição. São Paulo, Revista dos Tribunais, 1998. p. 23-41.

${ }^{200}$ C. R. DINAMARCO. Instituições de direito processual civil. p. 124.

201 Exercício semelhante, com objetivo diverso, e baseado no direito francês, foi feito por F.K. COMPARAto. Esssai d'analyse dualiste de l'obligation en droit privé. Paris, Dalloz, 1964. p. 121127.
} 
ocorrem fora do âmbito do Poder Judiciário. A verdade é que a ordem jurídica brasileira já convive há bastante tempo com um conjunto variado de situações em que há execução fora do processo civil, sem que se afirme que elas tenham vulnerado as garantias do devido processo legal ou tenham prejudicado a integridade da jurisdição dos tribunais brasileiros. A terceira e última finalidade é a de colocar à prova o argumento de BETTI sobre o fundamento da proibição do pacto comissório e demonstrar que não vigora, no direito brasileiro, um princípio equivalente ao defendido por esse autor.

\subsubsection{Realização da garantia sem processo, ou atuação da sanção civil, sem processo civil.}

O processo civil empreendeu, sobretudo ao longo do século $\mathrm{XX}$, um notável esforço para se afirmar como campo autônomo do conhecimento jurídico. Tiveram um papel fundamental nesse movimento: (a) a qualificação da relação jurídica processual como relação de direito público ${ }^{202}$; (b) a consequente rejeição do modelo da relação jurídica de direito privado como base para a definição dos conceitos fundamentais do processo civil ${ }^{203}$; e (c) a formulação da teoria do processo pela perspectiva do Estado-juiz, ou da coletividade, e não pela perspectiva do autor, suposto titular do direito subjetivo que busca o seu reconhecimento e realização forçada ${ }^{204}$. Essa trajetória do processo civil, como saber jurídico próprio, colocou em evidência a distância que hoje o separa da teoria geral do direito privado. Apesar desse distanciamento, não seria exagerado afirmar que uma parte significativa das demandas que os cidadãos levam ao Poder Judiciário visam à efetivação de poderes e deveres, em sentido amplo, que integram relações jurídicas de direito privado. Logo, é salutar perseguir a formulação de uma linguagem teórica minimamente comum ao processo civil e ao direito privado.

Os estudiosos do processo civil e do direito privado, atualmente, não se utilizam de uma terminologia compartilhada, que facilite uma colaboração mais

\footnotetext{
202 Ovídio B. DA Silva. Curso de processo Civil. v. 1. p. 16-21.

203 E. T. LIEBMAn. Processo de execução. p. 62-71, tratando do fundamento jurídico do poder de excutir o patrimônio do devedor.

${ }^{204}$ C. R. DinAMARCO. Instituições de direito processual civil. v. I. p. 107-110, refutando o que chama de "processo civil do autor".
} 
ativa na tentativa de incrementar a efetividade e a qualidade da prestação jurisdicional dirigida ao direito privado. Perdeu-se, por exemplo, nessa separação, a possibilidade de diálogo entre esses dois ramos do saber jurídico sobre um conceito caro à teoria geral do direito privado. Trata-se do conceito, já sublinhado nesta exposição, de garantia da relação jurídica de direito privado. Além das partes, do objeto e do fato jurídico que lhe dá origem, é também elemento constitutivo da relação jurídica de direito privado a chamada garantia $^{205}$. O elemento garantia não está presente apenas nas relações jurídicas de direito privado em que o poder, em sentido amplo, conferido ao sujeito ativo se dirige a um comportamento do sujeito passivo (caso em que o inadimplemento reclama, para sua reparação, a condenação e/ou a execução). Também há garantia nas relações jurídicas em que esse poder se qualifica como direito potestativo ou, mais precisamente, como poder formativo, ou seja, como poder, em sentido estrito, de provocar a instauração, modificação ou extinção de relação jurídica, mediante simples declaração ou manifestação negocial, com ou sem formalidades especiais, devidamente comunicada aos destinatários indicados pela lei ou pelo contrato ${ }^{206}$. Nesses casos, MotA PINTO afirma que há "uma garantia mais forte do que a garantia correspondente aos direitos subjectivos propriamente ditos - uma garantia infalível. É que a contraparte do direito potestativo não pode infringir esse direito; está num estado de sujeição.”207. Há uma variedade muito representativa de situações em que, por força de lei, e apesar da inegável existência de lide (entendida como conflito de interesses qualificado por pretensão resistida ou insatisfeita), a garantia da relação jurídica torna-se efetiva, e é colocada em plena atuação a chamada sanção civil, sem que disso participe, necessariamente, o Estado-juiz, e sem que se forme relação jurídica processual.

\footnotetext{
205 Cf. M. D. DE ANDRADE. Teoria geral da relação jurídica. v. I. Sujeitos e objecto. Coimbra, Coimbra Editora, 1983. p. 19-27, para quem a garantia constitui o: "conjunto dos meios sancionatórios a adoptar pelo Estado, por intermédio dos seus tribunais, contra o sujeito do dever jurídico, quando ele não cumpre espontâneamente, observando o comportamento prescrito. Ou talvez. melhor: é a possibilidade facultada ao titular do direito de fazer adoptar essas providências contra o obrigado remisso; de fazer, em suma, funcionar contra este, pelo modo adequado em conformidade com a ordem jurídica, o aparelho sancionatório estadual, instituído para prover de tutela eficaz os comandos jurídicos, em ordem a assegurar a sua normal observância"; no mesmo sentido, o já citado C.A. Mota PINTO. Teoria geral do direito civil. p. 168-189.

${ }^{206}$ M. D. DE ANDRADE. Teoria geral da relação jurídica. p. 28-29.

${ }^{207}$ C.A. MotA PINTO. Teoria geral do direito civil. p. 188-189; continua o autor, para complementar o argumento: "A realização dos efeitos do direito potestativo - efeitos situados no mundo ideal das relações jurídicas, isto é, dos produtos do pensamento - está assegurado necessariamente, enquanto nos direitos subjectivos propriamente ditos, apesar do direito a indemnização, a garantia pode falhar, v.g., porque o infractor não tem solvabilidade".
} 


\subsubsection{Inventário (não exaustivo) de hipóteses de realização da garantia sem processo, no direito brasileiro vigente ${ }^{208}$.}

(a) Desforço imediato e direito de retenção.

Há dois primeiros casos de realização extraprocessual da garantia da relação jurídica que podem ser chamados de escolares. São aqueles previstos nos artigos $1.210, \S 1^{\circ}$, e 1.219 do Código Civil. O primeiro dos dispositivos estabelece que: “O possuidor turbado, ou esbulhado, poderá manter-se ou restituir-se por sua própria força, contanto que o faça logo; os atos de defesa, ou de desforço, não podem ir além do indispensável à manutenção, ou restituição da posse”. O segundo prevê que:

"O possuidor de boa-fé tem direito à indenização das benfeitorias necessárias e úteis, bem como, quanto às voluptuárias, se não the forem pagas, a levantá-las, quando o puder sem detrimento da coisa, e poderá exercer o direito de retenção pelo valor das benfeitorias necessárias e úteis".

Direito de retenção semelhante é outorgado ao locatário pelo art. 35 da Lei n. ${ }^{\circ} 8.245$, de 18 de outubro de 1991, segundo o qual:

"Salvo expressa disposição contratual em contrário, as benfeitorias necessárias introduzidas pelo locatário, ainda que não autorizadas pelo locador, bem como as úteis, desde que autorizadas, serão indenizáveis e permitem o exercício do direito de retenção".

\footnotetext{
${ }^{208}$ Em geral, não é da melhor técnica de redação transcrever os artigos de lei a que se faz referência. Neste item, porém, escolhe-se fazer diversas transcrições pois elas exercem um papel crucial na construção do argumento. A reprodução do texto da lei evidencia o caráter intestino e orgânico das diversas hipóteses legais citadas. Mais do que servir de apoio ou referência, os dispositivos a seguir transcritos compõem o argumento desenvolvido. Daí a pertinência da transcrição.
} 
Nesses casos, o próprio interessado, titular do direito material, é autorizado pela lei a oferecer resposta à resistência encontrada, mediante o exercício do desforço imediato ou da retenção do bem.

(b) Direito de vizinhança e servidão.

A análise dos chamados direitos de vizinhança permite identificar outra situação em que o proprietário pode fazer atuar, por seus próprios meios, a garantia da relação jurídica de direito privado. O art. 1.283 do Código Civil, realmente, estatui que: "As raízes e os ramos de árvore, que ultrapassarem a estrema do prédio, poderão ser cortados, até o plano vertical divisório, pelo proprietário do terreno invadido". O art. 1.384 do Código Civil também autoriza expressamente a particulares a prática de atos materiais de conformação da realidade dos fatos a interesses juridicamente tutelados:

"A servidão pode ser removida, de um local para outro, pelo dono do prédio serviente e à sua custa, se em nada diminuir as vantagens do prédio dominante, ou pelo dono deste e à sua custa, se houver considerável incremento da utilidade e não prejudicar o prédio serviente".

Também nesses casos, a lei confere diretamente ao interessado o poder de praticar os atos que concretizam a resposta da ordem jurídica à violação de um direito.

(c) Exceção de contrato não cumprido e compensação.

Embora nem sempre sejam vistas como tais, a verdade é que a exceção de contrato não cumprido (art. 476 do Código Civil) e a compensação (art. 368 e seguintes do Código Civil) correspondem a garantias de relações jurídicas aptas a serem deflagradas pelos particulares sem a intervenção do Estado-juiz. Sobre a exceção de contrato não cumprido, MENEZES LEITÃo esclarece que o exercício de posição jurídica tal como a tratada pelo art. 476 do Código Civil resulta em que uma 
das partes "se veja numa posição superior à dos credores comuns em relação à satisfação do seu crédito, desempenhando assim a exceptio não apenas uma função coercitiva, mas também uma função de garantia"209. A respeito da compensação, o mesmo autor explica que essa figura promove a realização do crédito, uma vez que "ele pode ser extinto, não apenas pelo pagamento, mas através de declaração de compensação com o contra-crédito que sobre ele tem o devedor" ${ }^{210}$. Pela mesma ótica, o exercício do poder formativo extintivo, outorgado pela cláusula resolutiva expressa, nos contratos bilaterais, também opera a realização de uma garantia da relação jurídica obrigacional (art. 474 e 475 do Código Civil). Trata-se da cláusula que, no art. 1.163 do Código Civil de 1916, recebia o epíteto de pacto comissório.

Merece especial atenção o art. 122, caput, da Lei de Falências, segundo o qual: "Compensam-se, com preferência sobre todos os demais credores, as dívidas do devedor vencidas até o dia da decretação da falência, provenha o vencimento da sentença de falência ou não, obedecidos os requisitos da legislação civil $^{\text {"211. }}$. Nessas hipóteses, a consequência jurídica prevista na norma é posta em atuação sem que seja exigida a intervenção do Poder Judiciário ou a instauração de processo. Em 1963, VILLELA já sustentava no Brasil a ideia da compensação como forma de garantia ${ }^{212}$.

(d) Penhor de créditos e títulos de crédito.

Ainda no corpo do próprio Código Civil, é possível identificar ao menos mais duas situações de realização da garantia da relação jurídica sem a necessidade de formação de relação jurídica processual que envolva o credor e o devedor. Nos casos de penhor de créditos ou títulos de crédito, o credor pignoratício pode vir a ter que propor ação de cobrança ou execução (se dispuser de título) para o recebimento do crédito ou do título empenhado; todavia, uma vez recebidos os

\footnotetext{
${ }^{209}$ L.M.T. MENEZES LEITÃO. Garantias das obrigações. p. 314.

${ }^{210}$ L.M.T. MENEZES LEITÃO. Garantias das obrigações. p. 315.

${ }^{211}$ Essa regra está presente no direito brasileiro ao menos desde 1908 (Decreto n. 2.024 , de 17 de dezembro de 1908, art. 49). As leis de falências que se seguiram não modificaram o sentido básico da norma, cf. art. 49 do Decreto n. ${ }^{\circ}$ 5.746, de 9 de dezembro de 1929 e art. 46 do Decreto-lei n. ${ }^{\circ} 7.661$, de 21 de junho de 1945.

212 J.B. VILlELA. Da compensabilidade no concurso falencial. Ensaio de contribuição à tutela dos créditos. Tese para doutoramento na Faculdade de Direito da Universidade de Minas Gerais. Belo Horizonte, s/ed., 1963. p. 43-50.
} 
valores diretamente do terceiro, contra quem se voltava o crédito ou o título objeto da garantia, a lei permite ao credor que se satisfaça automaticamente com o respectivo produto, sem a necessidade de ser iniciado processo judicial em que o devedor pignoratício figure como réu ou executado. É o que se lê nos artigos 1.455, parágrafo único, e 1.459, inciso IV, do Código Civil. De acordo com o primeiro: "Estando vencido o crédito pignoratício, tem o credor direito de reter, da quantia recebida, o que lhe é devido, restituindo o restante o devedor; ou a excutir a coisa a ele entregue". O segundo dispositivo estabelece que: "Ao credor, em penhor de título de crédito, compete o direito de: (...) - receber a importância consubstanciada no título e os respectivos juros, se exigíveis, restituindo o título ao devedor, quando este solver a obrigação".

Assim, se o devedor da obrigação cartular efetua o pagamento ao credor pignoratício, e o devedor pignoratício se mostra inadimplente, o credor pignoratício tem por lei o direito de "ficar com" a importância paga pelo terceiro. Isso se dá em caráter definitivo, sem que o credor pignoratício tenha para tanto o ônus de iniciar e levar a cabo processo judicial de execução contra o devedor pignoratício.

(e) Disciplina dos armazéns-gerais, no Decreto $n .^{\circ}$ 1.102/03.

A disciplina dos armazéns-gerais foi modificada, em relevante medida, pela Lei n. ${ }^{\circ} 11.076 / 04^{213}$. Todavia, permanece vigente o Decreto ${ }^{\circ}{ }^{\circ} 1.102$, de 1903, no que se refere à guarda de bens que não sejam produtos agropecuários. Esse decreto contempla duas hipóteses principais de atuação da sanção civil sem intervenção do Estado-juiz. O primeiro desses casos consta do respectivo art. 14 do decreto, que confere, às ali designadas empresas (sic) de armazéns-gerais, direito de retenção das mercadorias junto a elas depositadas, para garantia e pagamento dos

\footnotetext{
${ }^{213}$ No que se refere a produtos agropecuários, a disciplina dos certificados de depósito e dos warrants contida no Decreto n. ${ }^{\circ} 1.102 / 1903$ foi substituída pelas normas da Lei n. ${ }^{\circ} 11.076 / 2004$, passando esses títulos a serem designados de Certificado de Depósito Agropecuário (CDA) e Warrant Agropecuário (WA).
} 
valores que lhes são devidos pelos depositantes, incluindo mas não se limitando a remunerações e diversos tipos de despesas" ${ }^{\text {,14. }}$.

Os artigos 23 e 24 do mesmo decreto contemplam, em favor do titular de warrant representativo de dívida não cumprida no prazo convencionado, procedimento sub-rogatório de expropriação e alienação de bens, e adjudicação do produto da venda, de modo nitidamente "independente de formalidades judiciais" (art. 23, $\S 1^{\circ}$, parte final). Havendo impontualidade e o consequente protesto do título (art. 23, caput), o portador do warrant tem o direito de promover a venda em leilão das mercadorias especificadas no título, por intermédio de corretor ou leiloeiro, sem necessidade de recurso ao Poder Judiciário. O corretor ou leiloeiro ficará então encarregado de comunicar o titular do armazém-geral e conferir publicidade ao leilão, mediante anúncios na imprensa (art. 23. $\S 3^{\circ}$ ). Feita a venda, o produto obtido será recebido pelo titular do armazém contra a entrega da mercadoria e deverá utilizado, em primeiro lugar, ao pagamento de impostos, da remuneração dos corretores ou leiloeiros e das despesas de armazenagem, cabendo o saldo ao portador do warrant (artigos 24 a 26).

Tudo se passa sem que seja necessária a propositura de ação de execução ou a atuação do Estado-juiz. Não se pode negar que, substancialmente, todos os atos praticados pelo credor, pelo titular do armazém e pelo leiloeiro ou corretor são equivalentes àqueles que ordinariamente caracterizam o processo de execução levado a efeito em juízo, segundo as regras do Código de Processo Civil.

(f) Art. 63 da Lei . $^{\circ} 4.591 / 64$.

Outra hipótese de realização de garantia fora do processo civil pode ser encontrada no art. 63 da Lei n. ${ }^{o}$ 4.591/64. Trata-se de previsão inserida na disciplina da construção de edificações em condomínio, que pode ser objeto de contratação sob regime de empreitada ou administração (art. 48 da referida lei). Ocorrendo inadimplemento das prestações ou pagamentos devidos pelo condômino,

214 “Art. 14. As empresas de armazéns-gerais têm o direito de retenção para garantia do pagamento das armazenagens e despesas com a conservação e com as operações, benefícios e serviços prestados às mercadorias, a pedido do dono, dos adiantamentos feitos com fretes e seguro, e das comissões e juros, quando as mercadorias lhe tenham sido remetidas em consignação.” 
a lei outorga à chamada Comissão de Representantes poderes explícitos de excussão da quota ou fração ideal de titularidade do inadimplente. $\mathrm{O}$ art. $63, \S 1^{\circ}$, estabelece que:

"Se o débito não for liquidado no prazo de 10 (dez) dias, após a solicitação da Comissão de Representantes, esta ficará, desde logo, de pleno direito, autorizada a efetuar, no prazo que fixar, em público leilão anunciado pela forma que o contrato previr, a venda, promessa de venda ou de cessão da quota de terreno e correspondente parte construída e direitos, bem como a sub-rogação do contrato de construção".

$\mathrm{O} \S 4^{\circ}$ desse mesmo dispositivo prevê que:

"Do preço que for apurado no leilão, serão deduzidas as quantias em débito, tomadas as despesas ocorridas, inclusive honorários de advogado e anúncios, e mais $5 \%$ (cinco por cento) a título de comissão e $10 \%$ (dez por cento) de multa compensatória, que reverterão em benefício do condomínio de todos os contratantes, com exceção do faltoso, ao qual será entregue o saldo, se houver".

Mais explícito e particularmente ilustrativo é o parágrafo seguinte $\left(5^{\circ}\right)$, segundo o qual:

"a Comissão de Representantes ficará investida de mandato irrevogável, isento do Imposto do Selo, na vigência do contrato geral de construção da obra, com poderes necessários para, em nome do condômino inadimplente, efetuar as citadas transações, podendo para este fim fixar preços, ajustar condições, sub-rogar o arrematante nos direitos e obrigações decorrentes do contrato de construção e da quota de terreno e construção; outorgar as competentes escrituras e contratos, receber preços, dar quitações; imitir o arrematante na posse do imóvel; transmitir o domínio, direito e ação; responder pela 
evicção; receber citação, propor e variar de ações; e também dos poderes ad juditia, a serem substabelecidos a advogado legalmente habilitado".

Conquanto seja duvidosa a técnica legislativa de qualificar como "mandato irrevogável" a origem desses poderes, a chamada Comissão de Representantes, nessas previsões legais, exerce essencialmente as mesmas funções desempenhadas pelo Estado-juiz na execução por quantia certa contra devedor solvente, conforme prevista no Código de Processo Civil.

(g) Execuções hipotecárias dos artigos 31 e seguintes do Decreto-lei n. ${ }^{\circ}$ 70/66.

Os artigos 31 a 38 do Decreto-lei n. ${ }^{\circ}$ 70/66, disciplinam uma das formas de excussão extrajudicial de bens mais debatidas no direito brasileiro ${ }^{215}$. Diferentemente do que ocorre em hipóteses previstas no Código Civil, em que a atuação da sanção civil é posta em marcha pelas mãos do próprio credor interessado, o mecanismo desenhado pelos referidos artigos do Decreto-lei n. ${ }^{\circ}$ 70/66 prevê a atuação de um agente fiduciário, a quem a lei atribui competências específicas para a prática de atos ditos sub-rogatórios, incluindo a expropriação, a venda em leilão, o recebimento do produto dessa alienação forçada e o pagamento do credor. O procedimento inicia-se com a apresentação, pelo credor ao agente fiduciário, de uma solicitação de execução da dívida, munida de documentos taxativamente enumerados pela lei (art. 31); essa solicitação, como se nota, exerce uma função análoga àquela da petição inicial. O agente fiduciário, a partir de então, tem prazos para notificar o devedor para que purgue a mora e, na inércia deste, fazer publicar editais visando à realização um ou dois leilões do imóvel hipotecado. O art. 35 - sem incorrer na imprecisão de tratar essa outorga de poderes como mandato - confere diretamente ao agente fiduciário os poderes necessários para a prática de todos esses atos, inclusive para receber o produto da venda em leilão, pagar as despesas incorridas e a sua

${ }^{215}$ Um apanhado dessas discussões, tanto doutrinárias como jurisprudenciais, pode ser encontrado em E. H. O. YoshIKAWA. Execução extrajudicial e devido processo legal. De modo mais resumido, mas bastante preciso sobre o assunto, cf. ARAKEN DE ASSIS. Manual da execução. $12^{a}$ edição. São Paulo: Revista dos Tribunais, 2009. p. 1055-1057. Este último autor estende-se em maiores detalhes sobre o procedimento especial contemplado na Lei $\mathrm{n}^{\circ}{ }^{\circ} 5.741$, de $1^{\circ}$ de dezembro de 1971, embora não deixe de apontar as decisões mais relevantes proferidas sobre a constitucionalidade do Decreto-lei n. ${ }^{\circ}$ 70/66. 
própria remuneração e entregar o saldo ao credor. O art. 41 prevê a hipótese de se recorrer ao juízo competente apenas para fins de substituição do agente fiduciário, ou para a apresentação de questionamento sobre a sua imparcialidade. Fora isso, os atos tendentes à realização da sanção civil ocorrem, por força de lei, à margem do processo judicial.

(h) Execução, pela companhia, de quantias devidas pelo acionista remisso.

Situação análoga nas sociedades limitadas.

$\mathrm{O}$ art. 107 da Lei . $^{\circ}$ 6.404/76, que rege o funcionamento das companhias, também contempla hipótese de excussão extrajudicial de bens. Estando o acionista em mora quanto à integralização das ações por ele subscritas, a companhia é autorizada por lei a, em lugar da propositura de ação judicial de execução, mandar vender as ações em bolsa, mediante leilão, por conta e risco do acionista inadimplente (art. 107, inciso II). Os parágrafos do referido artigo detalham a publicidade que deve cercar esse leilão e conferem à companhia credora o poder de, com o produto da venda, recuperar as despesas com o procedimento, saldar o débito e colocar eventual saldo à disposição do inadimplente, na sede social. Esse mecanismo de excussão extrajudicial não foi uma inovação da lei acionária de 1976. Ele apenas reproduz, com alterações pouco representativas, o que já constava do Decreto-lei n. ${ }^{\circ}$ 2.627, de 26 de setembro de 1940, este sim inovador em relação ao direito que lhe era anterior, como nota VALVERDE ${ }^{216}$.

De modo análogo, no âmbito das sociedades limitadas, o art. 1.058 do Código Civil estabelece que:

"Não integralizada a quota de sócio remisso, os outros sócios podem, sem prejuízo do disposto no art. 1.004 e seu parágrafo único, toma-la para si ou transferi-la a terceiros, excluindo o primitivo titular e devolvendo-lhe o que houver pago, deduzidos os juros de mora, as prestações estabelecidas no contrato, mais as despesas".

${ }^{216}$ T.M. VALVERDE. Sociedade por ações (comentários ao decreto-lei $n$. 2.627, de 26 de setembro de 1940). v. II (arts. 74 a 136). $3^{\text {a }}$ edição. Forense: Rio de Janeiro, 1959. p. 20-25. 
(i) Art. 32 da Lei $n .^{\circ}$ 6.766/79.

As regras do art. 32 da Lei n. ${ }^{\circ}$ 6.766/79 (que disciplina o parcelamento do solo urbano) não chegam a tratar de mecanismos de expropriação e venda extrajudicial de bens. Mas dão corpo a mais uma hipótese de atuação da sanção civil, ou deflagração de garantia da relação jurídica, sem a instauração, desenvolvimento e término de processo judicial. Há a conformação coercitiva da realidade à situação prevista no comando jurídico, sem a intervenção do Estado-juiz. A norma em apreço estabelece a rescisão (rectius: resolução) do contrato de promessa de compra e venda de lote urbano pelo simples decurso do prazo de 30 (trinta) dias, após a constituição do devedor em mora, sem a respectiva purgação. A intimação do devedor é feita pelo oficial do registro de imóveis, que, após passado em branco o aludido prazo, terá a incumbência de cancelar a averbação do contrato mediante requerimento do vendedor ( $\operatorname{art} .32, \S 3^{\circ}$ ). Tudo ocorre, novamente, sem que seja preciso lançar mão de ação judicial, nem mesmo para ordenar ao oficial do registro o cancelamento da averbação antes realizada.

(j) Alienação fiduciária de bens imóveis na Lei n. ${ }^{\circ}$ 9.514/97.

A Lei n. ${ }^{\circ}$ 9.514/97, com a redação conferida pela Lei n. ${ }^{\circ}$ 10.931/04 (artigos 26 e 27, essencialmente), também cria procedimento de excussão extrajudicial de bens equivalente àquele de execução judicial disciplinado pelo Código de Processo Civil. Em lugar do agente fiduciário, que tem papel de relevo na execução hipotecária extrajudicial (Decreto-lei n. ${ }^{\circ}$ 70/66), o terceiro a quem a lei incumbe a prática de atos executórios é o oficial do registro de imóveis. A este cumpre notificar o devedor, pessoalmente ou por edital, para que purgue a mora no prazo de 15 (quinze) dias (art. $26, \S 1^{\circ}$ ); não sendo paga a dívida e os respectivos consectários nesse prazo, o oficial do registro de imóveis deve averbar a consolidação da propriedade na matrícula do imóvel, mediante o pagamento do tributo incidente sobre essa transferência (art. $26, \S 7^{\circ}$ ).

Consolidada a propriedade sob a titularidade do credor fiduciário, a lei determina que este passe a realizar diretamente, sem participação do oficial de 
registro de imóveis, os atos necessários a realização de leilões públicos de venda do imóvel. A lei outorga ao credor fiduciário poderes para receber o preço, pagar-se do valor do principal, juros e despesas e, após, restituir eventual saldo ao devedor fiduciante (art. 27). O papel do oficial do registro de imóveis é bastante limitado. Suas atribuições são mais restritas do que aquelas do agente fiduciário na execução hipotecária.

(k) Sistema de pagamentos brasileiro.

A Lei n. ${ }^{\circ}$ 10.214/01 regula a atuação das câmaras e dos prestadores de serviços de compensação e de liquidação, mediante a criação e a disciplina do chamado sistema de pagamentos brasileiro ("SPB"). Segundo o artigo $8^{\circ}$ dessa lei, o inadimplemento de qualquer participante do sistema deve ser remediado:

"I - com a tradição dos ativos negociados ou a transferência dos recursos, no caso de movimentação financeira; e II - com a entrega do produto da realização das garantias e com a utilização dos mecanismos e salvaguardas de que tratam os $\$ \S 2^{\underline{o}}$ e $3^{\underline{o}}$ do art. $4^{\underline{o}}$, quando inexistentes ou insuficientes os ativos negociados ou os recursos a transferir".

No caso de, depois de adotadas essas providências, haver saldo positivo, ele será transferido ao participante inadimplente. A garantia da relação jurídica mais uma vez atua sem a participação do Poder Judiciário.

(l) Execução forçada de acordo de voto.

De acordo com a mesma Lei n. $^{0}$ 6.404/76, com as modificações introduzidas pela Lei n. $^{\circ} 10.303$, de 31 de outubro de 2001, o descumprimento de obrigações de voto assumidas em acordo de acionistas arquivado na sede social também permite a realização da garantia da relação jurídica sem o concurso do Poder Judiciário. Nos termos do $\S 8^{\circ}$ do art. 118, a lei atribui explicitamente ao presidente da assembleia poderes para "não computar voto proferido com infração de acordo de 
acionistas devidamente arquivado". Cabe àquele que preside o conclave - e não ao Poder Judiciário - contrastar o voto apresentado com o acordo de acionistas e efetivamente dizer o direito, isto é, qualificar o voto como infrator do acordo e aplicar a sanção correspondente, que é a sua desconsideração. Já o $9^{\circ}$ do mesmo art. 118 estatui que a parte prejudicada pela ausência ou abstenção de outro acionista signatário do acordo ou de membro do conselho de administração que esteja vinculado ao acordo pode, nessa hipótese, "votar com as ações do acionista ausente ou omisso e, no caso de membro do conselho de administração, pelo conselheiro eleito com os votos da parte prejudicada". O que se percebe é que a lei outorga a particulares, e não ao Poder Judiciário (que pode naturalmente ser provocado ex post facto), competências tanto jurisdicionais como jurissatisfativas, na elucidativa dicção de NEVES ${ }^{217}$.

(m) Crédito consignado em folha de pagamento (Lei $\left.n .^{\circ} 10.820 / 03\right)$

Os artigos $1^{\circ}$ e $6^{\circ}$ da Lei $.^{\circ} 10.820 / 03$ permitem que empregados e beneficiários da previdência social autorizem "de modo irrevogável e irretratável" seus empregadores ou o Instituto Nacional do Seguro Social - INSS, conforme o caso, a efetuar o desconto de parcelas destinadas ao pagamento de empréstimos diretamente do salário ou benefício previdenciário que lhes é periodicamente pago. Mediante tal autorização, o empregador e o INSS têm a obrigação de "efetuar os descontos autorizados pelo empregado em folha de pagamento e repassar o valor à instituição consignatária" (art. $3^{\circ}$, inciso III, e art. $6^{\circ}, \S 2^{\circ}$, inciso I). Permite-se, assim, a dedução compulsória dos pagamentos devidos ao credor diretamente dos valores devidos ao empregado ou beneficiário da previdência social, independentemente de nova colaboração do devedor, distinta daquela prestada quando da contratação do empréstimo, e independentemente também de qualquer recurso ao Poder Judiciário. Tem-se aqui, sem dúvida, nova forma de satisfação privada e coativa do crédito.

${ }^{217}$ C. NEVES. Estrutura fundamental do processo civil. Tutela jurídica processual, ação, processo e procedimento. Rio de Janeiro: Forense, 1997. p. 33. 
(n) Alienação fiduciária no mercado financeiro e de capitais.

A Lei n. ${ }^{\circ}$ 10.931/04 imprimiu modificações também na Lei n. ${ }^{\circ} 4.728$, de 14 de julho de 1965, que disciplina o mercado de capitais. Uma dessas modificações - a de maior interesse para este trabalho - foi a introdução de um novo art. 66-B, contendo regras aplicáveis à alienação fiduciária em garantia no mercado financeiro e de capitais. De acordo com o $\$ 3^{\circ}$ desse dispositivo legal:

"É admitida a alienação fiduciária de coisa fungível e a cessão fiduciária de direitos sobre coisas móveis, bem como de títulos de crédito, hipóteses em que, salvo disposição em contrário, a posse direta e indireta do bem objeto da propriedade fiduciária ou do título representativo do direito ou do crédito é atribuída ao credor, que, em caso de inadimplemento ou mora da obrigação garantida, poderá vender a terceiros o bem objeto da propriedade fiduciária independente de leilão, hasta pública ou qualquer outra medida judicial ou extrajudicial, devendo aplicar o preço da venda no pagamento do seu crédito e das despesas decorrentes da realização da garantia, entregando ao devedor o saldo, se houver, acompanhado do demonstrativo da operação realizada".

Mais uma vez, a sanção civil é posta em marcha, e a garantia da relação jurídica é realizada, sem o manejo de ação judicial, de execução ou eventual outra, e sem que se precise provocar o Poder Judiciário.

(o) Nova disciplina da execução no Código de Processo Civil

Na própria sistemática da execução judicial, nota-se uma tendência recente de diminuir as atribuições que cabem ao juiz. Após as modificações decorrentes da Lei n. ${ }^{\circ} 11.382$, de 6 de dezembro de 2006, a possibilidade de adjudicação passou a preceder a praça ou hasta pública (art. 685-A), com o propósito de diminuir a frequência desses últimos eventos no curso do processo judicial. Tentou-se, também, obviar os expedientes de avaliação, permitindo-se a sua 
realização pelo próprio oficial de justiça, de modo contemporâneo à realização da penhora (art. 652 e 680). Outro intento foi o de permitir a colaboração de terceiros no processo de venda dos bens penhorados, como alternativa à realização dessas tarefas pelas próprias mãos do Poder Judiciário (art. 685-C).

\subsubsection{O que se conclui, a partir desse inventário?}

É possível que existam outros tantos casos de deflagração de garantia ou aplicação de sanção civil que, por força de lei, prescindem do processo civil e do Poder Judiciário. Procurou-se aqui dar ênfase aos casos que guardam maior proximidade com o direito privado. No campo do direito público, o princípio da auto-executoriedade dos atos administrativos talvez torne esse elenco ainda mais amplo e variado. Apesar de provavelmente não esgotar todas as hipóteses de jurissatisfação sem processo, acredita-se que o inventário realizado já alcançou o objetivo a que se propôs.

Comprovou que é frequente, na legislação em vigor, a atribuição de poderes coercitivos e coativos ao próprio interessado ou a terceiros chamados a agir no seu interesse (como o agente fiduciário na execução hipotecária ou o oficial do registro de imóveis na alienação fiduciária de bens imóveis). Esse fenômeno, embora pareça destoar da sistemática geral constante do Código de Processo Civil, está longe de ser excepcional ou marginal no direito brasileiro.

A alienação fiduciária, seja de bens imóveis, seja aquela realizada no mercado financeiro ou de capitais, seja ainda aquela voltada ao financiamento de atividades agropecuárias ${ }^{218}$, tem tomado vulto crescente na praxe contratual; é seguramente o mecanismo de financiamento preferido das instituições financeiras, pois em caso de falência permite o exercício do pedido de restituição ${ }^{219}$, não é atingido pela recuperação judicial ${ }^{220}$ e ainda pode autorizar a execução sem necessidade de concurso do Poder Judiciário, como visto acima. O mesmo pode ser dito em relação ao penhor de créditos ou títulos de crédito, que também conta com

\footnotetext{
${ }^{218}$ A alienação fiduciária é uma das garantias que pode respaldar a emissão de Cédulas de Produto

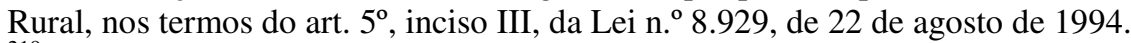

${ }^{219}$ Art. 85 e seguintes da Lei de Falências.

${ }^{220}$ Art. $49, \S 3^{\circ}$, da Lei de Falências.
} 
regra protetiva específica em caso de ajuizamento de recuperação judicial pelo devedor ${ }^{221}$.

As operações de crédito consignado em folha de pagamento, segundo dados do Banco Central do Brasil, apresentavam em maio de 2012 um saldo total de $\mathrm{R} \$ 172,3$ bilhões de reais, e correspondiam a cerca de $60 \%$ do total dos empréstimos bancários feitos a pessoas físicas ${ }^{222}$.

É igualmente grande a importância prática dos acordos de acionistas para o funcionamento das companhias e grupos societários, sobretudo aquelas de maior porte, que exigem a fixação de regras e mecanismos sofisticados de colaboração entre diversos investidores. Esses mecanismos estão apoiados nos dispositivos autoexecutórios (self-enforcing) dos $\S \S 8^{\circ}$ e $9^{\circ}$ da Lei n. $.^{\circ} 6.404 / 76$.

Fica inviável, nesse contexto, continuar a tratar essa realidade - da realização da garantia fora do processo e à margem do Poder Judiciário - como se fosse algo excepcional, que escapa às explicações geralmente fornecidas sobre os conceitos de jurisdição e de monopólio do Estado-juiz na realização das garantias das relações jurídicas e na atuação das sanções civis.

Como conciliar essa "fuga do Judiciário", em matéria de execução, com a visão de que a tutela executiva se qualifica necessariamente como jurisdicional e de que o Estado detém o monopólio da atuação da sanção civil? A chave para essa questão, segundo aqui se defende, está no seguinte: a circunstância de uma atividade ser, em substância, sujeita ao direito público e representar uma autêntica função pública não significa, necessariamente, que ela precise ser realizada diretamente pelo Estado. Há diversas funções públicas que, por força de lei, são delegadas e exercidas por particulares, sem que por esse motivo deixem de ser

\footnotetext{
${ }^{221}$ Art. $49, \S 5^{\circ}$, da Lei de Falências.

${ }^{222}$ Os dados são de agosto de 2011, e foram consultados em http://www.febraban.org.br/Noticias1.asp?id_texto=1287\&id_pagina=61\&palavra=consignado, aceso em 04.11.2012. Cf. também a matéria Quanto vale o consignado? (Revista Isto É. Edição n. ${ }^{\circ} 2227$, de 13 de julho de 2012, consultada em http://www.istoe.com.br/reportagens/221370_QUANTO+VALE+O+CONSIGNADO+), tratando da joint venture dentre o banco Itau e o Banco BMG nesse segmento; acesso em 11.11.2012. A matéria informa ainda que $85 \%$ dos mutuários do crédito consignado são servidores públicos.
} 
públicas ou de estar sujeitas ao direito público, como é o caso das concessões de serviços públicos. Ao legislar, o Estado simplesmente reconhece que, nesses casos, o interesse público pode ser melhor atendido se tais atividades forem realizadas pelos próprios particulares. Isso ocorre, sem grandes sobressaltos, em relação a atividades do Poder Legislativo e do Poder Executivo. Não há porque ser diferente em relação ao Poder Judiciário. Aliás, é o que de certo modo já se reconhece na arbitragem, em relação às atividades processuais de caráter cognitivo e de medidas de urgência em litígios que versem sobre direitos patrimoniais disponíveis.

A identificação desse fenômeno - de realização de funções públicas por particulares - foi feita no Brasil, com precisão, por COMPARATO, em estudo sobre a natureza jurídica das bolsas de valores ${ }^{223}$. Pela análise dos dispositivos da Lei n. ${ }^{\circ}$ 6.385, de 7 de dezembro de 1976 (artigos 15, IV, 17 e 18), o autor conclui que "as bolsas de valores, em nosso sistema de mercado de capitais, exercem um autêntico serviço público". Para fundamentar essa assertiva, o autor nota, com apoio em publicistas franceses, italianos e alemães, que são em geral três os aspectos que levam ao reconhecimento de uma atividade como serviço público. O primeiro considera a circunstância de o agente responsável pela condução da atividade ser um agente estatal. $\mathrm{O}$ segundo refere-se ao fato de a atividade ser exercida com as prerrogativas inerentes à atuação do Poder Público, isto é, de ela ser munida de poder de polícia. O terceiro e último aspecto diz respeito à finalidade da atividade, ou seja, à consecução do interesse público como móvel de seu exercício. Em sequência a essa constatação, o mesmo autor demonstra que o primeiro aspecto - tratar-se de agente estatal - é falho e tem sido progressivamente preterido na identificação das funções e serviços públicos:

"as exigências inerentes à instituição de um Estado intervencionista levaram, em vários países, à criação de pessoas jurídicas privadas como titulares - e não apenas concessionárias - de serviços de utilidade pública"

(...)

${ }^{223}$ F.K. COMPARATO. Natureza jurídica das bolsas de valores e delimitação do seu objeto. Revista de direito mercantil, industrial, econômico e financeiro. São Paulo. n. 60. 1985. p. 45-53. 
"o direito moderno já não exige que a gestão de um serviço público seja feita por um órgão da Administração Pública"224.

Essas afirmações foram feitas para analisar uma situação distinta daquela engendrada pelos casos de realização da garantia da relação jurídica fora do processo civil. Cuidava-se ali do exercício do poder de polícia no mercado de capitais. Apesar disso, é possível sustentar que esse mesmo raciocínio é de todo aplicável e útil para descrever, de modo adequado, o que se passa no campo da deflagração da sanção civil fora do processo civil. Assim como a lei opera, no âmbito do Poder Executivo, a delegação a particulares do exercício de competências e prerrogativas ínsitas ao imperium estatal, como é o caso do poder de polícia, o mesmo pode ocorrer em relação ao Poder Judiciário. Havendo, a critério da lei, conveniência e oportunidade, até mesmo o poder dar voz de prisão e cercear de imediato a liberdade de alguém pode ser feito "por qualquer do povo", conforme estabelece o art. 301 do Código de Processo Penal. À luz do que já se passa em relação a outros poderes estatais, não parece que exista alguma nota que diferencie tanto o poder exercido pelo Estado-juiz no processo de execução, a ponto de a lei não poder delegar a sua realização a particulares, sejam eles partes interessadas ou terceiros.

Se o direito brasileiro já convive bem com o instituto da arbitragem cujas decisões adquirem força de coisa julgada - não há motivo para que se recuse licitude ou constitucionalidade ao exercício, por particulares, de poderes jurisdicionais de cunho executivo. Esses poderes não perdem, por essa circunstância, a característica de estarem sujeitos ao direito público. Se: (a) tanto a jurisdição, em sentido estrito, como a jurissatisfação, são formas de tutela jurídica processual, e se (b) os poderes tradicionalmente exercidos pelo Poder Judiciário no âmbito do processo de conhecimento podem ser exercidos por particulares, como já ocorre na arbitragem, não há porque recusar licitude ao desempenho de atividades executivas por particulares, fora dos domínios do Poder Judiciário. Isso ocorre em diversas hipóteses legais, conforme aqui se procurou demonstrar.

${ }^{224}$ F.K. COMPARATO. Natureza jurídica das bolsas de valores e delimitação do seu objeto. p. 48-49. 
Fica assim assentado, pelo exposto acima, que o monopólio do Estado na atuação da sanção civil e na realização das garantias das relações jurídicas de direito privado está longe, no direito brasileiro, de ser um princípio absoluto ou de não poder ser afastado pela própria lei.

Não se advoga, aqui, que o Poder Judiciário deva perder qualquer prerrogativa de sustar uma execução extrajudicial abusiva, ou de apreciar a legalidade e constitucionalidade de qualquer ato praticado nessa seara. A ampla possibilidade de controle pelo Poder Judiciário e recurso aos juízes e tribunais não é em qualquer momento vulnerada pelas hipóteses legais em questão, seja nos casos em que ela já é admitida, seja em eventuais novas situações para as quais a lei venha a prever a sua realização.

Diante dos argumentos até aqui alinhavados, não se deve mais considerar a autotutela e a justiça de mão própria $^{225}$ como resquícios empoeirados de priscas eras, que se esqueceu de proscrever do direito positivo. Trata-se, ao contrário, de estruturas jurídicas de que a legislação pode se valer, e já o faz, com frequência, para melhor atingir seus objetivos. A lei pode, com efeito, reconhecer que a atuação da sanção civil será realizada de modo mais profícuo por determinados particulares do que por agentes estatais lotados no Poder Judiciário. Em diversas situações, outros que não o Estado-juiz estão em posição mais adequada para fazer atuar o comando jurídico previsto na norma. Nesses casos, de que são exemplos todos aqueles citados neste item 4.3, pode-se prescindir da atuação do Poder Judiciário como um intermediário necessário ou incontornável no caminho entre o inadimplemento e a realização das garantias das relações jurídicas de direito privado, incluídas as garantias dos créditos. Isso não quer dizer que qualquer prejudicado, seja credor, seja devedor, não possa recorrer ao Poder Judiciário para se defender de abusos ou condutas ilegais, quer antes, quer durante, quer após a execução extrajudicial. O que se verifica é que a figura da justiça de mão própria é hoje mais atual e mais condizente com as exigências do tempo presente do que a atribuição excessiva e exacerbada de funções ao Estado-juiz, que presidiu a elaboração do Código de Processo Civil de 1973 e do Código Civil de 2002. Esses diplomas legais

\footnotetext{
${ }^{225}$ Para uma análise da justiça de mão própria, cf. C. NEVES. Estrutura fundamental. p. 3-19.
} 
superestimam a necessidade de o Estado estar presente em diversos momentos da organização e do funcionamento da sociedade, o que reflete as circunstâncias históricas de sua elaboração e não se justifica nos dias que correm.

Conclui-se dessa forma que - embora o argumento de BETTI sobre o fundamento da proibição do pacto comissório tenha mérito por apresenta-lo em bases teoricamente compatíveis com o regime de nulidade que o caracteriza - não se pode toma-lo por condizente com o direito positivo brasileiro. A lei brasileira já contempla uma ampla e variada gama de casos de satisfação coativa de direitos que prescindem da intermediação do Estado-juiz, muitos deles contratuais ${ }^{226}$. Não se pode sustentar que vigore no Brasil - como um monolito onipresente e insuperável - um suposto princípio absoluto de monopólio do Estado no exercício das atividades jurisdicionais executivas ou jurisatisfativas. No direito brasileiro vigente, não é esse o fundamento subjacente à proibição do pacto comissório.

\subsection{Interesse social em coibir a difusão do pacto comissório.}

Após examinar as diferentes justificativas ventiladas sobre a vedação do pacto comissório (inclusive a que será tratada no item 4.5), BIANCA não se satisfaz com nenhuma delas, isoladamente ${ }^{227}$. Sua argumentação aponta para as circunstâncias de que: (a) a sanção para o descumprimento da proibição é a invalidade absoluta; e (b) a aplicação dessa sanção independe da apuração concreta de prejuízo ao devedor ou aos demais credores do devedor. Diante desse regime jurídico, seria inelutável concluir, segundo BIANCA, que o interesse motivador da proibição corresponderia ao interesse de prevenir um dano geral (em oposição a danos particulares do devedor ou dos demais credores), que seria inerente à tão-só liberdade de contratar o pacto comissório ${ }^{228}$.

\footnotetext{
${ }^{226}$ Em 1971, F.K. COMPARATO assinalava: "O credor garantido por direito real não tem necessidade de via coletiva, porquanto a sua garantia pode realizar-se normalmente em execução singular e, algumas vezes até mesmo fora do processo". Pedido ajuizado por credores trabalhistas. Se estão eles adstritos a renunciar a seu privilégio. In: Estudos e pareceres de direito empresarial. Rio de Janeiro, Forense, 1978. p. 411-417. O trecho transcrito consta da p. 416.

${ }^{227}$ Além do já citado Il divieto del patto comissorio. p. 215-218, o tema é discutido pelo autor também no verbete Patto comissorio do Novissimo Digesto Italiano. p. 711-721.

${ }^{228}$ C.M. BIANCA. Il divieto del patto comissorio. p. 216-217. O autor busca alinhar seu entendimento com contribuições de autores do direito comum medieval (entre eles, DonELLUS) e nota que posição semelhante é adotada por VIVANTE, segundo o qual o objetivo da lei, em relação ao pacto comissório,
} 
O mesmo autor, porém, é pouco enfático, e de certo modo inconclusivo, ao tentar descrever qual seria esse interesse geral, distinto do interesse na proteção do devedor e dos direitos dos demais credores. São feitos comentários sobre a política de crédito, a integridade do sistema geral de garantias e a preservação da função de garantia exercida pelo patrimônio do devedor. Nada substancialmente distinto, segundo aqui se entende, da ideia de ordenar adequadamente as relações de coordenação e subordinação de interesses que se entremeiam e se chocam na realização das garantias de cumprimento das obrigações, seja a garantia em sentido estrito (isto é, o bem objeto de penhor, hipoteca, anticrese ou outra), seja a garantia em sentido amplo, que serve a todos os credores subordinados aos titulares de garantias reais. Essa ideia de ordenação dos interesses que se dirigem contra o patrimônio do devedor, em verdade, não se distingue de uma concepção razoavelmente ampla do princípio da par conditio creditorum e da garantia financeira dos créditos, a que se fez referência no item 2.2.

Esta tese defende ser insuficiente o argumento de que o pacto comissório, se praticado de modo generalizado, seria socialmente danoso. Deve-se reconhecer nele a virtude de deslocar o problema para um enquadramento menos apegado aos interesses do devedor ou de credores concretamente considerados, e mais voltado aos interesses gerais da coletividade. Esse simples deslocamento, porém, não resolve o problema. Para que se afirme, de modo convincente, que o pacto comissório não pode ser amplamente praticado, pois isso seria socialmente danoso, é preciso também dizer, com a mesma clareza e convicção, qual o dano que com isso se produziria. Não basta dizer que se trata de um dano de caráter geral, como parece fazer BIANCA.

é impedir que ele se torne uma cláusula de praxe, ampla e diuturnamente utilizada. Realmente, ao comentar o art. 459 do código comercial italiano de 1882, VIVANTE sustenta que: "La legge volle impedire che il patto commissorio diventasse un patto di stile, che il debitore fosse sempre costretto a subire la legge del creditore". Em tradução livre: "A lei quer impedir que o pacto comissório se torne um pacto de praxe, que o devedor seja sempre constrangido a sucumbir às imposições do credor". Del contratto di assicurazione - di pegno - di deposito nel magazzini generali. Art. 417-479 Cod. Comm. (Il codice di commercio commentato. Coord. Leone Bolaffio, Alfredo Rocco, Cesare Vivante. $6^{a}$ ed. $v$. VII). Torino, UTET, 1936. p. 523-525. 
$\mathrm{O}$ argumento deste autor assemelha-se a uma espécie de "conta de chegada", em que se busca um fundamento supostamente condizente com os efeitos da fattispecie. Fica em segundo plano a consistência da explicação. Em resumo, o fundamento da proibição defendido por esse autor, embora seja coerente com o regime jurídico aplicável (nulidade, independentemente da prova de dano, ao devedor ou a terceiros), não consegue escapar da necessidade de se apontar a quem ou a que fere a celebração de pacto comissório e qual o real motivo dessa suposta ofensa.

BIANCA não esclarece porque o conjunto da sociedade restaria prejudicado pela difusão do pacto comissório. Sob a ótica desta tese, em especial, não é possível identificar, no direito positivo brasileiro, elementos capazes de socorrer o argumento desse autor. O que se pode sustentar, ao contrário, é que a reconhecida licitude da dação em pagamento do bem dado em garantia, celebrada após o vencimento, também se coloca como um obstáculo à atribuição de um sentido coerente e lógico à proibição estudada. Não se compreende, de fato, o porquê de a celebração ser tida por socialmente danosa antes do inadimplemento, e socialmente aceitável após o inadimplemento.

Resta assim analisar uma última entre as possíveis justificativas para a vedação do pacto comissório. Trata-se do interesse geral de tutelar a coletividade dos credores do devedor, que podem ser prejudicados se este se desfizer de bens por valor superior ao da dívida garantida, ou se for violada a ordem de preferência dos créditos em caso de insolvência. 


\subsection{Preservação da par conditio creditorum $^{229}$.}

Deve-se a CARNELUTTI o estabelecimento de relações entre o pacto comissório e a proteção dos interesses dos demais credores do devedor ${ }^{230}$. São duas

${ }^{229}$ Cf. artigos 957, 958, 961 e 962 do Código Civil: "Art. 957. Não havendo título legal à preferência, terão os credores igual direito sobre os bens do devedor comum. Art. 958. Os títulos legais de preferência são os privilégios e os direitos reais.(...) Art. 961. O crédito real prefere ao pessoal de qualquer espécie; o crédito pessoal privilegiado, ao simples; e o privilégio especial ao geral. Art. 962. Quando concorrerem aos mesmos bens, e por título igual, dois ou mais credores da mesma classe especialmente privilegiados, haverá entre eles rateio proporcional ao valor dos respectivos créditos, se o produto não bastar para o pagamento integral de todos". É possível afirmar que o primeiro desses artigos, em especial, expressa a vigência do princípio da par conditio creditorum no direito brasileiro. Trata-se de uma igualdade entre os credores da mesma classe ou categoria, e que se subordina à existência dos referidos "títulos legais de preferência". Esses títulos operam efeitos legítimos somente até o limite do valor do crédito a que estão atrelados. Sobre as dificuldades que o tema encerra, e que há séculos deram azo ao emprego da locução "labirinto dos credores", cf. A. BuZAID. Do concurso de credores no processo de execução. São Paulo, Saraiva, 1952. A expressão "labirinto dos credores" parece ter origem na obra Labyrinthus Creditorum, de Salgado de Somoza, cf. registra também C. Neves. Comentários ao código de processo civil. v. VII (arts. 646-795). $7^{\text {a }}$ edição. Rio de Janeiro, Forense, 1999. p. 231-237. Para explicações sintéticas e precisas do princípio, cf. F.C. PONTES DE MIRANDA. Tratado de direito privado. t. XXIX. $3^{\text {a }}$ edição. São Paulo, Revista dos Tribunais, 1984. p. 233; e ARAKEN DE ASSIS e E. R. MALACHINI. Comentários ao código de processo civil.v. 10. (arts. 736 a 795). São Paulo, Revista dos Tribunais, 2001. p. 594-596. Sobre as distinções cabíveis entre direitos reais de garantia e privilégios creditórios, cf. F.K. ComPaRATO. Pedido ajuizado por credores trabalhistas. p. 414-416. Sobre o sentido relativamente limitado dessa igualdade entre os credores, e o aspecto mais saliente das relações de subordinação entre os interesses dos diferentes credores, cf. J.B. VILLELA. Da compensabilidade no concurso falencial. p. 61-62.

${ }^{230}$ F. CARNELUTTI. Note sul patto commissorio. p. 487-492. No caso discutido por CARNELUTTI nesse artigo, a Corte de Apelação de Veneza entendeu que era nula, por afronta à proibição do pacto comissório, a promessa de venda da coisa empenhada, por preço predeterminado, feita pelo devedor ao credor, de modo condicionado ao inadimplemento. O então professor da Universidade de Padova critica a decisão. Ao fazê-lo, ele deixa claro que, a seu ver, o respeito ao princípio insculpido no art. 1.884 do código civil italiano de 1865 (que vedava o pacto comissório) visava à tutela do devedor e principalmente dos demais credores: "il motivo dela nullità non consiste affato, como sostengono alcuni scrittori, nel diffeto di libertà da parte del debitore, ma nella tutela dell 'interesse del debitore stesso e debli altri creditori (chirografari)". Em tradução livre: "o motivo da nulidade de fato não consiste, como sustentam alguns escritores, em eventual 'defeito de liberdade' em relação ao devedor, mas na tutela do interesse do devedor propriamente dito e dos demais credores (quirografários)". A despeito dessas ponderações, CARNELUTTI defende que a proibição do pacto comissório busca impedir uma espécie de execução forçada de base contratual, que não teria lugar em uma promessa consensual de compra e venda do bem empenhado (p. 490). Nesse ponto específico, parece haver uma aproximação entre as exposições de CARNELUTTI e BETTI, que se explica pela redação do art. 1884 do código civil italiano de 1865. Para ilustrar seu pensamento, CARNELUTTI formula pergunta que bem demonstra a percuciência de seu raciocínio: "se io non trovo um cane di sovventore, il quale mi presti a pegno sul mio fondo così che, stretto da bisogno, per far denaro, lo vendo senz'altro al cinquantum per cento del suo valore, la legge tiene fermo il contratto; se trovo invece um galantuomo, il quale mi presta com ipoteca il novanta per cento purchè io gli prometa, se non pago, de vendergli per quel prezo il fondo, la legge riterrebbe nullo il contratto! Perchè??". Em tradução livre: "se eu não encontro um cachorro de um agiota, que me empreste tomando em garantia meu imóvel de modo que, premido pela necessidade, para conseguir dinheiro, vendo simplesmente esse imóvel por cinquenta por cento de seu valor, a lei tem o contrato por válido; se em vez disso encontro um homem de bem, que me empresta sob hipoteca noventa por cento do preço do imóvel pois lhe prometo que, em caso de inadimplemento, concordo vender o imóvel por esse mesmo preço, a lei estabelece que esse contrato é nulo! Por quê?"' (p. 490). No mesmo sentido de que o fundamento da proibição do pacto comissório está relacionada com a preservação da par conditio creditorum, cf. V. ANDRIOLI. Commentario. p. 5051. 
as principais formas pelas quais o pacto comissório pode lesar os demais credores do devedor.

A primeira diz respeito ao excesso que pode haver - e geralmente há na comparação entre o valor de mercado do bem dado em garantia, de um lado, e o valor da dívida garantida, de outro. Ao se assenhorear do bem, em definitivo, por ocasião do inadimplemento, o credor pode alcançar um enriquecimento injustificado, caso o valor de mercado do bem, no momento do vencimento, seja superior ao da dívida. Ao diminuir desproporcionalmente o patrimônio do devedor, o credor em apreço subtrai deste valores indevidos, prejudicando a garantia geral que assiste aos demais credores. Há, assim, uma necessidade de controle - jurídico, mas não necessariamente judicial - sobre o valor pelo qual são excutidos os bens do devedor.

O segundo modo pelo qual a apropriação automática do bem objeto de garantia pelo credor pode prejudicar os demais credores diz respeito à ordem de preferência dos créditos, em caso de insolvência do devedor. Essa ordem é matéria de ordem pública e não está sujeita a alteração por força de disposições contratuais $^{231}$. O direito real de garantia representa justamente uma prioridade do seu titular - oponível contra os demais credores - na excussão do bem que lhe serve de objeto. Essa prioridade, todavia, não é absoluta.

Antes do pagamento de quaisquer créditos, devem ser atendidos, em verdade, os chamados pedidos de restituição ${ }^{232}$. Deles podem se socorrer: (a) os proprietários de bens em posse do devedor; (b) os titulares de garantias representadas por alienação fiduciária; (c) aqueles que celebraram com o devedor contratos de

\footnotetext{
${ }^{231}$ Há pelo menos três conjuntos distintos de dispositivos legais que, no direito brasileiro, disciplinam a ordem de preferência dos créditos: (a) no Código Civil, os artigos 955 a 964; (b) no Código de Processo Civil, o art. 769, que remete às disposições do Código Civil; e (c) por fim, na própria Lei de Falências, artigos 83, 84 e 86, entre outros.

${ }^{232}$ De acordo com o art. 149 da Lei de Falências: "Art. 149. Realizadas as restituições, pagos os créditos extraconcursais, na forma do art. 84 desta Lei, e consolidado o quadro-geral de credores, as importâncias recebidas com a realização do ativo serão destinadas ao pagamento dos credores, atendendo à classificação prevista no art. 83 desta Lei, respeitados os demais dispositivos desta Lei e as decisões judiciais que determinam reserva de importâncias.". Para uma análise rigorosa do pedido de restituição, ainda na vigência do Decreto-lei n. ${ }^{\circ} 7.661 / 45$, cf. S. MARCONDES. Restituição na lei falimentar e a figura especial do art. 76, $\S 2^{\circ}$. In: Problemas de direito mercantil. São Paulo, Max Limonad, 1970. p. 339-366. Também sobre o tema, na vigência da lei falimentar anterior, cf. T.M. VAlverde. Comentários à lei de falências. v. II. $4^{\mathrm{a}}$ edição. Atualizada por J.A. Penalva Santos e Paulo Penalva Santos. Rio de Janeiro, Forense, 1999. p. 31-71.
} 
arrendamento mercantil (leasing); e (d) as instituições financeiras que tenham celebrado com o devedor contratos de adiantamento sobre contratos de câmbio para exportação (art. 86, II, da Lei de Falências, e art. 75 da Lei n. ${ }^{\circ}$ 4.728/65). Se a coisa não mais existir ao tempo do pedido de restituição, está deverá ser feita em dinheiro (art. 86, I, da Lei de Falências).

Na sequência, são considerados extraconcursais, e devem ser pagos antes de quaisquer outros: (a) os créditos listados no art. 84 da Lei de Falências ${ }^{233}$; e (b) os créditos decorrentes do fornecimento de bens ou serviços ao devedor durante o processo de recuperação judicial (art. 67 da Lei de Falências).

De acordo com o art. 83, inciso I, da Lei de Falências, os créditos derivados da legislação do trabalho, limitados a cento e cinquenta salários mínimos por credor, e os decorrentes de acidentes de trabalho, também têm também prioridade em relação aos créditos com garantia real. A prioridade finalmente subsequente, dada pelo inciso II do mesmo art. 83 aos créditos com garantia real está restrita, por um lado, "ao limite do valor do bem gravado" 234 e, por outro lado, ao valor do débito propriamente dito ${ }^{235}$.

Estão ainda imunes ao concurso os créditos passíveis de compensação, nos termos do Código Civil e do art. 122 da Lei de Falências.

\footnotetext{
${ }^{233}$ Para que não pairem dúvidas, o texto do dispositivo é o seguinte: "Art. 84. Serão considerados créditos extraconcursais e serão pagos com precedência sobre os mencionados no art. 83 desta Lei, na ordem a seguir, os relativos a: I - remunerações devidas ao administrador judicial e seus auxiliares, e créditos derivados da legislação do trabalho ou decorrentes de acidentes de trabalho relativos a serviços prestados após a decretação da falência; II - quantias fornecidas à massa pelos credores; III - despesas com arrecadação, administração, realização do ativo e distribuição do seu produto, bem como custas do processo de falência; IV - custas judiciais relativas às ações $e$ execuções em que a massa falida tenha sido vencida; $V$ - obrigações resultantes de atos jurídicos válidos praticados durante a recuperação judicial, nos termos do art. 67 desta Lei, ou após a decretação da falência, e tributos relativos a fatos geradores ocorridos após a decretação da falência, respeitada a ordem estabelecida no art. 83 desta Lei”.

${ }^{234}$ Cf. F.C. PONTES DE MIRANDA. Comentários ao código de processo civil. t. XI. (arts. 736-795). Rio de Janeiro, Forense, 1976. p. 482: "Quando se fala de crédito, que é preferente, porque tem garantia real, apenas se abrevia a definição: crédito que tem de ser satisfeito com o valor que está gravado pelo direito real limitado, constituído ou transferido em garantia do crédito. Não é do devedor essa parcela do bem, é do titular do direito real, que coincide, ex hypothesi, ser o credor concursal.".

${ }^{235}$ Sobre a ordem de classificação dos créditos na falência, cf. R. SZTAJN e V.H. DE MELLO FRANCO. Falência e recuperação da empresa em crise. Comparação com as disposições do direito europeu. Rio de Janeiro, Elsevier, 2008. p. 41-50; e o artigo do Des. S.L.O. CRUZ. Classificação dos créditos na falência. In: A nova lei de falências e de recuperação de empresas - Lei $n^{\circ}{ }^{11}$ 1.101/05 (coord. Paulo Penalva Santos). Rio de Janeiro, Forense, 2007. p. 205-221.
} 
A situação não difere, no essencial, ao se deslocar a atenção para o concurso civil de credores, disciplinado no Código de Processo Civil ${ }^{236}$. Também nele, os credores trabalhistas, ou por acidente de trabalho, têm prioridade sobre os titulares de garantias reais (art. 449, $§ 1^{\circ}$, da Consolidação das Leis do Trabalho, Decreto-lei n. ${ }^{\circ}$ 5.452, de $1^{\circ}$ de maio de 1943, e aplicação analógica dos artigos 83 e 151 da Lei de Falências ${ }^{237}$ ). Ao lado dos créditos trabalhistas, subordinam também os créditos amparados por garantias reais os pagamentos dos ditos encargos da massa, por aplicação analógica do art. 84 da Lei de Falências ${ }^{238}$. Diferentemente do que ocorre na Lei de Falências, no concurso civil, os créditos tributários (incluindo aqueles relacionados à previdência social) de titularidade de todos os entes federativos também devem ser atendidos com antecedência em relação aos titulares de garantias reais (artigos 186, caput, e 187, caput, do Código Tributário Nacional, Lei n. 5.172 de 25 de outubro de 1966$)^{239}$. Somente depois do pagamento dos créditos trabalhistas, dos encargos da massa e dos créditos tributários é que terá lugar, no concurso civil, a satisfação dos credores titulares de garantias reais. A isso se seguirão, eventualmente, os pagamentos destinados aos credores titulares de privilégios especiais, gerais e quirografários, nessa ordem.

Assim, tanto na falência como na insolvência civil, a excussão do bem dado em garantia pelo tão só evento do inadimplemento, tal como operada pelo pacto comissório (se lícito fosse), poderia prejudicar a observância da ordem de preferência dos créditos, conforme estabelecida pela lei. Transmutando-se em proprietário, por força do vencimento, o credor protegido por pacto comissório estaria autorizado a

\footnotetext{
236 Sobre o tema, cf. A. BUZAID. Do concurso de credores no processo de execução. São Paulo, Saraiva, 1952; F.C. PONTES DE MIRANDA. Comentários ao código de processo civil. t. XI. (arts. 736795). Rio de Janeiro, Forense, 1976; C. NEVES. Comentários ao código de processo civil. v. VII (arts. 646-795). $7^{\text {a }}$ edição. Rio de Janeiro, Forense, 1999; ARAKEN DE ASSIS e E. R. MALACHINI, Edson Ribas. Comentários ao código de processo civil. v. 10. (arts. 736 a 795). São Paulo, Revista dos Tribunais, 2001; e H. THEODORO JR. A insolvência civil. Execução por quantia certa contra devedor insolvente. $5^{\text {a }}$ edição. Rio de Janeiro, Forense, 2003.

${ }^{237}$ Sobre essa aplicação analógica, cf. H. THEODORO JR. A insolvência civil. Execução por quantia certa contra devedor insolvente. p. 366; e ARAKEN DE ASSIS e E. R. MALACHINI, Edson Ribas. Comentários ao código de processo civil. p. 690-691.

${ }^{238}$ Idem à nota imediatamente anterior.

${ }^{239}$ De acordo com essas normas, que vigoram com força de lei complementar: "Art. 186. O crédito tributário prefere a qualquer outro, seja qual for sua natureza ou o tempo de sua constituição, ressalvados os créditos decorrentes da legislação do trabalho ou do acidente de trabalho."; "Art. 187. A cobrança judicial do crédito tributário não é sujeita a concurso de credores ou habilitação em falência, recuperação judicial, concordata, inventário ou arrolamento.".
} 
formular o pedido de restituição previsto no art. 85 da Lei de Falências. Desse modo, tal credor seria atendido antes de outros que estariam à sua frente, caso ele fosse mero credor titular de garantia real. Já os credores titulares de privilégios especiais ou gerais, bem como os credores quirografários - todos subordinados aos titulares de garantias reais - podem ser prejudicados pelo pacto comissório na medida em que este represente pagamento excessivo ao credor, em relação ao montante do seu crédito. O privilégio, de acordo com COMPARATO, "não é propriamente um direito, mas uma qualidade que adjetiva o direito pessoal de crédito, e consiste na preferência de pagamento em confronto com outros créditos"; essa prelação manifesta-se única e exclusivamente em caso de abertura de concurso de credores; nunca antes disso ${ }^{240}$. A mesma possibilidade de prejuízo pode atingir os créditos tributários, que em caso de falência também são subordinados à prévia satisfação dos credores aparelhados por garantias reais (art. 83, incisos II e III, da Lei de Falências).

Não basta, porém, apenas identificar essas fortes imbricações entre a proibição do pacto comissório e a preservação da par conditio creditorum. Para esclarecer adequadamente as relações entre os dois temas, é necessário testar a coerência da sanção representada pela nulidade do pacto comissório com os demais remédios previstos na legislação para tutelar o princípio da igualdade de tratamento entre os credores.

A primeira figura jurídica a que se deve fazer menção, nesse particular, é a da fraude contra credores (art. 158 a 165 do Código Civil) ${ }^{241}$. Enfrentase, nesse ponto, a mesma dificuldade já encontrada quando da análise do possível fundamento representado pela tutela do devedor fragilizado. A incongruência é a seguinte: (a) por um lado, para a tutela dos demais credores, a parte geral do Código Civil estabelece a sanção de mera anulabilidade ou mesmo ineficácia ${ }^{242}$; e (b) por

${ }^{240}$ F.K. COMPARATO. Legitimidade da fazenda pública para ajuizar pedido de falência. In: Ensaios $e$ pareceres de direito empresarial. Rio de Janeiro, Forense, 1978. p. 418-431. O trecho citado consta da p. 429.

${ }^{241}$ Sobre o tema, ainda na vigência do Código Civil de 1916, cf. O. NoNATO. Fraude contra credores (da ação pauliana). Rio de Janeiro, Editora Jurídica e Universitária, 1969.

${ }^{242}$ A despeito da dicção legal, a doutrina e a jurisprudência têm sustentado que o que se verifica nos casos de fraude contra credores não é anulabilidade, nas sim ineficácia; por todos, cf. H. THEODORO JR. em nota acrescida a O. GOMES. Introdução. p. 431-432. Em sentido diverso, e com o cuidado de atentar para os diferentes regimes que decorrem da disciplina legal falimentar, M.B. DE MELLO. Teoria do fato jurídico. Plano da validade. p. 168-171. Também para uma análise específica da fraude 
outro lado, para um caso particular (pacto comissório), que não se diferencia do caso geral em sua reprovabilidade, impõe-se uma sanção mais grave, de nulidade.

Além dessa primeira incoerência, cabe apontar que, tanto nos casos de fraude à execução (artigos 592 e 593 do Código de Processo Civil), como nos casos sujeitos às disposições do art. 129 da Lei de Falências, o regime jurídico aplicável é o também é o da ineficácia ${ }^{243}$.

Ainda sobre o princípio da par conditio creditorum, é preciso sublinhar que a sua atuação tem lugar apenas em caso de insolvência do devedor. É lapidar a observação de MARCONDES, segundo a qual o caráter unitário do patrimônio se bifurca, no sistema concursal ${ }^{244}$. Dessa bifurcação resulta: (a) de um lado, a regra da responsabilidade patrimonial, pela qual todos os bens do devedor constituem garantia comum dos credores; e (b) de outro lado, a regra de igualdade de tratamento desses mesmos credores. Assevera esse autor que: "Tais postulados, estáticos quando é solvente o devedor, tornam-se atuantes, ao sobrevir a insolvência, pelo desdobro das regras adequadas à apuração do ativo e à verificação do passivo" 245.

Existem, portanto, correlações importantes entre a proibição do pacto comissório e a observância do princípio da par conditio creditorum. O eventual funcionamento lícito do pacto comissório pode prejudicar tanto credores que - por força de lei - têm prioridade em relação aos titulares de garantias reais, como também credores que estão em posição de subordinação a esses mesmos titulares. No primeiro caso, os efeitos do pacto comissório podem fazer com que o credor por ele amparado "passe à frente" de credores que têm prioridade legal na satisfação de seus direitos. No segundo caso, os efeitos do pacto comissório podem transferir

contra credores no contexto falimentar, cf. S. MARCONDES. Da fraude contra credores; falência e alienação de estabelecimento. In: Questões de direito mercantil. São Paulo, Saraiva, 1977. p. 125-147; e T.M. VALVERDE. Comentários à lei de falências. v. I. p. 371-398.

243 Sobre o regime jurídico da ineficácia, cf. A. JUNQUEIRA DE AZEVEDO. Negócio jurídico. Existência, validade e eficácia. São Paulo, Saraiva, 2000. p. 60-69; e M.B. DE MELlo. Teoria do fato jurídico. Plano da eficácia. $1^{a}$ parte. São Paulo, Saraiva, 2003. p. 60-73. Segundo este último autor, a ineficácia é a "inaptidão, temporária ou permanente, do fato jurídico para irradiar os efeitos próprios e finais que a norma jurídica lhe imputa" (p. 60).

${ }^{244}$ S. MARCONDES. Restituição na lei falimentar e a figura especial do art. $76, \S 2^{\circ}$. p. 339-340.

${ }^{245}$ S. MARCONDES. Restituição na lei falimentar e a figura especial do art. 76, §2 $2^{\circ}$. p. 339. 
indevidamente, ao credor que dele se vale, montantes superiores ao valor do débito, prejudicando a garantia geral dos demais credores a ele subordinados. Como regra, porém, essas consequências danosas e indesejáveis apenas se processarão em caso de insolvência do devedor e abertura de concurso de credores.

A previsão legal de nulidade do pacto comissório, todavia, não explicita qualquer diferenciação em sua incidência conforme a circunstância de estar solvente ou insolvente o devedor, nem conforme a eventual abertura de concurso de credores, seja ele civil, seja falimentar. Ainda que assim não fosse, essa previsão legal de nulidade estaria em contradição com os demais remédios que a legislação estabelece para o mesmo problema, nas hipóteses de fraude contra credores, fraude a execução e naquelas previstas no art. 129 da Lei de Falências, que é a simples ineficácia.

$\mathrm{Na}$ reforma legislativa francesa de 2006, analisada no item 3.1.6, a decisão de extinguir a proibição do pacto comissório veio acompanhada da modificação do direito concursal, precisamente no sentido de tornar a cláusula ineficaz na superveniência de processo equivalente ao de recuperação judicial ou falência.

Assim, após a análise de todos os fundamentos usualmente considerados para justificar a proibição do pacto comissório, permanece sem explicação, senão a de cunho apenas histórico, o porquê de tal vedação permanecer sancionada por nulidade no direito brasileiro ${ }^{246}$.

Em que pese essa conclusão, o norte metodológico desta tese consiste em uma postura de inquietação, e de contrafogo, a esse non liquet. Como anunciado no item 1.3, busca-se aqui empreender um esforço de reconstrução racional, em que o material estudado - depois de decomposto - deve ser reformulado segundo critérios de coerência e ordenação ${ }^{247}$. Passa-se, assim, a uma parte decisiva do pretendido diálogo com o legislador racional de que nos fala FERRAZ Jr.. Nela

\footnotetext{
246 Em sentido semelhante, considerando o debate italiano sobre o tema, M.I. BRUGGI. Patto comissório (voce). Enciclopedia Giuridica. Roma, Istituto della Enciclopedia Italiana (Treccani), s/d. p. 4-6.

${ }^{247}$ N. MACCORMICK. Rhetoric and the rule of law. p. 29.
} 
procura-se apresentar uma leitura da proibição do pacto comissório que: (a) seja condizente com as máximas de racionalidade, que se postula informarem o direito vigente, e (b) que se mostre aceitável, sob a égide de um sistema unitário e racional de conhecimentos e preferências, que, para fins de interpretação, também se supõe ínsito à legislação ${ }^{248}$.

\subsection{A reconstrução de um sentido para a proibição do pacto comissório no direito brasileiro.}

A conclusão que se atingiu até aqui é que, bem analisados, nenhum dos fundamentos geralmente apontados para justificar a vedação do pacto comissório mostra-se realmente condizente com o direito positivo brasileiro. Seria possível, apesar disso, urdir um sentido coerente para essa proibição?

Para essa pergunta, esta tese procurará oferecer uma resposta apoiada, inicialmente, em duas premissas principais. A primeira diz respeito à reconhecida licitude do pacto marciano. A segunda corresponde à inexistência de óbice legal à apropriação definitiva do objeto da garantia pelo credor nos casos em que esse objeto já está nominado em dinheiro. São os casos de (a) penhor de créditos e títulos de crédito; (b) alienação fiduciária em garantia no mercado de capitais; (c) das liquidações de garantias realizadas no âmbito do sistema de pagamentos brasileiro, hipóteses às quais se soma (d) a legalidade do desconto, em folha de pagamento, ou de benefício previdenciário, dos valores correspondentes a pagamentos de empréstimos sujeitos à Lei n. ${ }^{\circ}$ 10.820/03 (crédito consignado).

\subsubsection{A licitude do pacto marciano.}

Segundo o pacto marciano, o titular da garantia fica autorizado a se apropriar do bem que lhe serve de objeto se essa transferência se der por valor estimado por terceiro isento, escolhido por consenso entre credor e devedor, antes ou após o vencimento da dívida ${ }^{249}$. No Brasil, além de contar com o juízo positivo de

\footnotetext{
${ }^{248}$ T.S. FERRAZ JR. Ato de julgar e senso de justiça. p. 299.

${ }^{249}$ M.I. FELIU REY. La prohibicion del pacto comissório y la opcion en garantia. p. 88-95.
} 
licitude manifestado por MOREIRA Alves, CARVAlHo SANTOS e FraGA ${ }^{250}$, é possível citar dois julgados relativamente recentes do Tribunal de Justiça do Estado de São Paulo em que se reconheceu ser válida a celebração de pacto marciano $^{251}$. Viu-se, no capítulo 3, que a validade do pacto marciano é amplamente reconhecida nas legislações estrangeiras. Na Argentina, no Chile e no México, ele conta com respaldo legal explícito (itens 3.1.7, 3.1 .8 e 3.1.9). O capítulo 3 demonstrou também que o direito luso-brasileiro conteve, durante séculos, previsão expressa sobre a licitude do pacto marciano. Isso ocorreu durante toda a vigência das três Ordenações, e restou refletido na Consolidação das Leis Civis (item 3.2.1).

A licitude do pacto marciano, contrastada com a ilicitude do pacto comissório, deita luz sobre uma das questões examinadas no item 4.5, relacionada à proteção dos demais credores do devedor. Trata-se da necessidade de impor controles sobre o valor pelo qual é excutido o bem objeto da garantia.

O que há de verdadeiramente reprovável no pacto comissório - e que se ilumina pela reconhecida validade do pacto marciano - é justamente a inexistência de escrutínio isento ou imparcial sobre a adequação entre o valor da dívida e o valor de mercado do bem dado em garantia. Esse escrutínio, no pacto marciano, dá-se por delegação consensual, a terceiro isento, da tarefa de estimar ou avaliar o bem, após o inadimplemento. Esse procedimento expurga o que há de genuinamente censurável no pacto comissório.

\subsubsection{A disciplina legal das situações em que a garantia já está nominada em dinheiro, no momento do vencimento.}

Essa identificação do âmago da proibição do pacto comissório é confirmada pela análise da disciplina legal do penhor de créditos e títulos de crédito,

\footnotetext{
${ }^{250}$ J.C. MoReIRA Alves. Alienação fiduciária em garantia. São Paulo, Saraiva, 1973. p. 127. Como visto no capítulo 3, manifestaram-se também de modo favorável à validade do pacto marciano, no direito brasileiro, J.M. CARVALHO SANTOS. Código civil brasileiro interpretado. p. 92-95 e A. FRAGA. Direitos reaes de garantia. p. 122.

${ }^{251}$ Apelação n. ${ }^{\circ} 1120758-0 / 2.6^{\text {a }}$ Câmara. Rel. Des. Romeu Ricúpero, j. 31.01.2008, e Apelação n. ${ }^{\circ}$ 581.973.4/2, Quarta Câmara de Direito Privado. Rel. Des. Ênio Santarelli Zuliani, j. 27.08.2009, ambos disponíveis em www.tj.sp.gov.br, acesso em 02.07.2011.
} 
da alienação fiduciária no mercado de capitais, das regras do sistema de pagamentos brasileiro e da disciplina do crédito consignado ${ }^{252}$.

De acordo com o art. 1.455, parágrafo único, do Código Civil, vencida a dívida, o credor titular de penhor sobre crédito tem o direito de reter, da quantia recebida, o que lhe é devido, restituindo o restante ao devedor, se houver. Do mesmo modo, segundo o art. 1.459, IV, do Código Civil, o credor pignoratício tem assegurado o direito de "receber a importância consubstanciada no título e os respectivos juros, se exigíveis, restituindo o título ao devedor, quando este solver a obrigação". A contrario sensu, se o devedor não solver a obrigação, a restituição não ocorre, e se torna definitivo o recebimento da importância em dinheiro paga pelo terceiro ao credor pignoratício. Situações equivalentes - já descritas no item 4.3.3 ocorrem (a) na alienação fiduciária em garantia no âmbito do mercado financeiro e de capitais (art. 66-B, $\S 3^{\circ}$, da Lei n. ${ }^{\circ}$ 4.728/65), (b) no sistema de pagamentos brasileiro (art. $8^{\circ}$, inciso I, da Lei n. $^{\circ} 10.214 / 01$ ) e (c) na disciplina do chamado crédito consignado (art. $3^{\circ}$, inciso III, e $6^{\circ}, \S 2^{\circ}$, inciso I, da Lei n. ${ }^{\circ} 10.820 / 03$ ).

Em todos esses casos, existe uma razão clara para que não se tenha, na proibição do pacto comissório, um obstáculo à realização imediata e por si só satisfativa da garantia. A garantia já incide sobre uma quantia de dinheiro, que é objeto (a) de pagamento feito por terceiros, (b) de título de crédito, (c) de valor mobiliário nominado em moeda corrente ou sujeito a negociação em bolsa ou mercado de balcão, ou (d) ainda recursos financeiros que compõem o salário ou benefício previdenciário do devedor.

Se os dois termos da comparação - a dívida, de um lado, e o bem objeto de garantia, de outro - já se acham nominados em dinheiro: (a) é desnecessária a avaliação por terceiro isento, como ocorreria no pacto marciano, também lícito; e (b) não se apresenta o risco de ficar encoberta a desproporção entre o montante da dívida e o valor de mercado do bem dado em garantia, nem do consequente enriquecimento injustificado do credor garantido, em prejuízo do

${ }^{252}$ Sobre a não incidência, na Itália, da vedação do pacto comissório nos casos de garantias que recaem sobre somas de dinheiro, cf. G. TUCCI. Garanzie sui crediti dell'impresa e tutela dei finanziamenti. L'esperienza statunitiense e italiana. Milano, Giuffrè, 1974. p. 167-169. 
devedor e dos demais credores. Se o valor da garantia, já nominada em dinheiro, for inferior ao montante do débito, o devedor continua obrigado pela insuficiência. Se o valor da garantia, já nominada em dinheiro, for superior ao montante do débito, o credor fica obrigado à restituição. Inexiste risco de prejuízo aos demais credores, ou ao próprio devedor.

Em reforço à lógica desse argumento, pode-se invocar, em primeiro lugar, o $\S 1.228,2$, do BGB, segundo o qual a conversão da obrigação garantida, qualquer que seja a sua espécie, em uma obrigação pecuniária, é requisito prévio e imprescindível à excussão do penhor, mediante a venda pública ou privada do bem dado em garantia. Em segundo lugar, essa é a mesma ratio subjacente à disciplina do $\S 9^{\circ}$ do UCC, conforme se nota pela explicação de um dos mais importantes arquitetos desse influente diploma legislativo ${ }^{253}$.

Por essas razões, o problema fundamental subjacente à vedação do pacto comissório pode ser reduzido à necessidade de controle sobre o valor pelo qual o bem objeto de garantia passa à propriedade do credor. Esta tese postula assim que: (a) existe, positivamente, um sentido, possível e devido, para a proibição do pacto comissório no direito brasileiro; e (b) ele consiste em impedir o enriquecimento injustificado do credor que, em caso de excesso do valor de mercado do bem dado em garantia em relação à dívida garantia, ocorreria não só à custa do patrimônio do devedor, mas à custa da garantia geral que ele representa para a coletividade dos credores. Caso sobrevenha a insolvência do devedor, a eventual eficácia do pacto comissório feriria a par conditio creditorum, subvertendo a ordem cogente de pagamentos aplicável na falência e no concurso civil de credores. No entanto, para se tornar coerente com tal fundamento, a sanção cabível para o caso de ser violada a

\footnotetext{
${ }^{253}$ Trata-se de G. GILMORE. Security interests in personal property. v. II. New Jersey, The Lawbook Exchange Ltd., 1999. p. 1221, segundo o qual: "When the value of the collateral is less than the amount of the secured obligation, the lender will insist on having the right to a deficiency judgment in addition to his security rights. (...) When the situation is reversed - the value of the collateral exceeds the amount of the secured obligation - the debtor has an equity which should be preserved, either for the debtor himself or, if he is insolvent, for his other creditors." Em tradução livre: "Quando o valor do bem dado em garantia é inferior ao valor da dívida garantida, o credor insistirá em obter uma condenação do devedor ao pagamento desse déficit, em acréscimo a seus direitos de garantia sobre o bem dado em garantia (...) Quando a situação é inversa - o valor do bem dado em garantia excede o valor da dívida garantida - o devedor tem um interesse legítimo nesse valor excedente, que precisa ser preservado, seja para o devedor propriamente dito, seja para os seus credores, caso ele esteja insolvente".
} 
proibição não deveria ser nulidade, mas sim a ineficácia. Pois é isso o que já ocorre nas hipóteses de fraude contra credores, fraude à execução e nos atos sujeitos ao art. 129 da Lei de Falências.

Sob essas premissas, não haverá razão para acoimar de ilícito o pacto comissório se existirem elementos capazes de: (a) impedir a ocorrência do mencionado excesso; ou (b) controlar adequadamente a sua verificação. Exemplos desses elementos são a avaliação do bem por terceiro isento, inerente ao pacto marciano, ou as situações em que o eventual excesso é imediatamente perceptível, pois a garantia, assim como a dívida pecuniária, já estão de pronto representadas por uma soma em dinheiro, ou por títulos nominados em dinheiro.

A circunstância de ter-se afastado a proteção do devedor e repressão à usura dos fundamentos da proibição do pacto comissório não elimina a possível incidência desses princípios em um dado caso concreto. $\mathrm{O}$ devedor que sofre lesão, ou que contrata em estado de necessidade, tem assegurado o direito de, dentro do prazo prescricional aplicável, pleitear e obter a anulação do negócio jurídico. Do mesmo modo, àqueles que praticarem negócio usurário, serão aplicáveis as disposições da Lei da Usura (artigos $1^{\circ}, 2^{\circ}$ e 13), da Lei dos Crimes contra a Economia Popular (art. $4^{\circ}$ ) e da Medida Provisória n. ${ }^{\circ}$ 2.172-32/01.

\subsubsection{A convergência entre esse sentido reconstruído, a estrutura do pacto comissório, a tradição do direito brasileiro e as soluções das legislações estrangeiras.}

Nos capítulos 2 e 3, puderam ser colhidos outros elementos importantes, que militam em favor do sentido aqui reconstruído para a proibição do pacto comissório. Eles reforçam as conclusões extraídas da licitude do pacto marciano (item 4.6.1) e das normas legais que disciplinam garantias já nominadas em dinheiro (item 4.6.2). Cumpre revisitá-los.

No capítulo 2, despontou a conclusão de que o pacto comissório - em sua estrutura - opera a realização da garantia (item 2.3.7). Por se cuidar da realização 
da garantia, cumpre estabelecer mecanismos de controle, jurídicos, mas não necessariamente judiciais, sobre o valor pelo qual o bem dado em garantia passa à titularidade do credor. Na disciplina do Código de Processo Civil (após a reforma promovida pela Lei n. ${ }^{\circ} 11.382$, de 6 de dezembro de 2006), a avaliação do bem penhorado constitui antecedente necessário dos atos de expropriação inerentes ao processo de execução (art. 685, parágrafo único). Esses atos de expropriação podem consistir em (a ordem é relevante): adjudicação do bem penhorado ao exequente, alienação por iniciativa particular, alienação em hasta pública e usufruto de bem móvel ou imóvel (art. 647). Tal avaliação apenas não é exigida se o exequente concordar com a estimativa de valor de mercado apresentada pelo executado, ou se o bem penhorado consistir em título ou mercadoria que disponha de cotação em bolsa, comprovada por certidão ou publicação oficial (art. 684).

Ora, a adjudicação do bem antes dado em garantia ao credor, e depois penhorado no curso do processo de execução, tem o conteúdo substancialmente equivalente ao pacto comissório, se ele lícito fosse, ou à dação em pagamento posterior ao vencimento a que se referem os parágrafos únicos dos artigos $1.365 \mathrm{e}$ 1.428 do Código Civil. Em todos esses casos, a titularidade do bem dado em garantia ou penhorado é transferida ao credor, para satisfação do débito, ainda que por diferentes caminhos. No processo de execução, essa transferência de titularidade, vestida de adjudicação, somente pode ocorrer após a verificação do valor de mercado do bem. Por consequência, essa adjudicação não pode ocorrer por preço inferior ao da avaliação (art. 685-A, do Código de Processo Civil).

Sendo o pacto comissório uma forma de realização da garantia alheia ao processo civil, a existência do "sistema unitário de conhecimentos e preferências", ínsita à hipótese do legislador racional, impõe que os valores protegidos nos dois campos, o judicial e o extrajudicial, sejam os mesmos ${ }^{254}$. Essa disciplina da excussão

\footnotetext{
${ }^{254}$ Nesse mesmo sentido, isto é, de que as diferentes formas de excussão de uma garantia, judiciais ou extrajudiciais, devem tratar de igual modo os diferentes interesses que concorrem ou conflitam a esse respeito, cf. G. GILMORE. Security interests in personal property. v. 2. p. 1225. Ao analisar questão semelhante no direito norte-americano, esse autor pondera: "But 'retention' under $\$ 9-505$ and 'disposition' under \$9-504 are merely alternative ways of liquidating the transaction between the foreclosing secured party and the debtor; they should have the same effect on competing interests". Em tradução livre: "Mas a retenção fundada no §9-505 [do UCC] e a alienação fundada no §9-504 [do UCC] são apenas formas alternativas de liquidação do negócio havido entre o exequente que detém
} 
judicial, ao lado da licitude do pacto marciano, e da disciplina legal da excussão das garantias já nominadas em dinheiro, corrobora a conclusão de que a verdadeira nódoa que macula o pacto comissório é a ausência de avaliação isenta do valor de mercado do bem ou direito dado em garantia, contemporânea ou posterior ao vencimento da obrigação.

Há assim - e deve de fato haver - um paralelismo lógico e valorativo, entre (a) a exigência de avaliação prévia à adjudicação e a consequente necessidade de a adjudicação seguir o valor da avaliação, que ocorrem no terreno do processo civil e (b) a vedação do pacto comissório, que deixa de ter lugar se ele estiver acompanhado do pacto marciano, no âmbito extraprocessual. Parece escapar a essa lógica, porém, a ausência de restrições legais à dação em pagamento do bem dado em garantia, posterior ao vencimento. A esse ponto se voltará adiante, no item 4.6.4.

No capítulo 3, verificou-se que o direito luso-brasileiro, até e inclusive na Consolidação das Leis Civis, sempre excepcionou, da vedação do pacto comissório, a hipótese de a transferência, ao credor, da titularidade do bem ou direito dado em garantia, dar-se "pelo justo preço", determinado por avaliação isenta. Essa tradição é surpreendentemente convergente, por exemplo, com a disciplina do direito norte-americano, constante do $\$ 9$ do UCC. Conforme descrito no item 3.1.10, a Section 9-610(c) do UCC estabelece que a aquisição do bem dado em garantia pelo próprio credor garantido apenas pode ocorrer (a) em hasta pública, ou seja, com publicidade que garanta a oportunidade de concorrência, e propicie uma alienação a preços de mercado; ou (b) mediante venda privada, somente nos casos em que o bem é negociado em bolsa ou mercado organizado, nos quais existam cotações públicas e confiáveis. Ausentes essas cotações, impõe-se a venda pública e não se tem dúvida sobre a razão de ser dessa exigência:

uma garantia e o devedor; elas deveriam ter o mesmo resultado para os interesses conflitantes envolvidos". As referências são à versão original do $\$ 9^{\circ}$ do UCC e não à versão revista e atualizada, que hoje está em vigor. Na versão original, os direitos e obrigações das partes e dos terceiros em caso de inadimplemento constavam do capítulo 5 do $\$$; na versão atual, foram deslocados para o capítulo 6. No direito continental europeu, essa homologia entre as formas coativas e não coativas de realização dos direitos é apontada por S. PUGLIATTI. Esecuzione forzata e diritto sostanziale. p. 11-16; e também em F. CARNELUTTI. Note sul patto commissorio. p. 487-492. 
"Without the sale, the possibility always remains that the creditor has picked up the property at too great a bargain, or, to reverse the focus and put it the language of the courts, the debtor has suffered a forfeiture. Recall that foreclosures are in equity, and 'equity', the maxim goes, 'abhors a forfeiture" ${ }^{\text {,255. }}$

Mesmo detendo raízes históricas muito distintas, o direito lusobrasileiro, de um lado, e o direito norte-americano, de outro, demonstram uma notável sintonia em relação aos fundamentos da proibição do pacto comissório. Ambos se preocupam, basicamente, em zelar pelo preço pelo qual o bem dado em garantia passa ao patrimônio do credor garantido. Também ao se consultar a lei alemã (item 3.1.5) e a lei francesa (item 3.6.1), percebeu-se a grande importância dada à existência de cotações públicas e confiáveis de preços, ou de mercado organizado em que seja negociado o bem dado em garantia, que permitam aferir se há uma proporção correta entre o valor de mercado do bem, no momento do vencimento, e o valor da dívida. A presença dessas circunstâncias torna lícita a venda privada do bem dado em garantia, e nada parece impedir que ela seja feita ao próprio credor. Fora desses casos, a venda deve ser pública, ou seja, suscetível à competição, ao menos potencial, entre possíveis interessados no bem dado em garantia (v.g. $\S \S$ 1.220 e 1.228 do BGB).

\subsubsection{A dação em pagamento, posterior ao vencimento.}

Como se explica, a partir do sentido aqui reconstruído, a autorização legal para que, após o vencimento, o devedor efetue, em favor do credor, a dação em pagamento do bem dado em garantia (parágrafos únicos dos artigos 1.365 e 1.428 do

${ }^{255}$ L.M. LOPUCKI e E. WARREN. Secured credit. A Systems approach. Sixth edition. Austin, Wolters Kluwer, 2009. p. 58. Em tradução livre: "Sem a venda [pública], sempre fica a possibilidade de o credor tomar a propriedade por uma pechincha ou, sob outra ótica e para usar a linguagem dos tribunais, de o devedor sofrer uma expropriação [forfeiture]. Lembre-se que as execuções estão sujeitas à equity, e que a equity, nos termos do brocardo, tem repulsa à expropriação [forfeiture]". A tradução de forfeiture como expropriação não é perfeita. A rigor, trata-se de um termo de sentido amplo definido como " a divestiture of specific property without compensation; it imposes a loss by taking away of some preexisting valid right without compensation" (Black's law dictionary. $6^{\text {th }}$ edition. St. Paul, Minnessota, West Group, 1990. p. 650). É tormentosa, e talvez sem solução, a tradução de equity, que o mesmo dicionário (p. 540) qualifica como "Justice administered according to fairness as contrasted with the strictly formulated rules of common law. It is based on a system of rules and principles which originated in England as an alternative to the harsch rules of common law and which were based on what was fair in a particular situation". 
Código Civil)? Há quem afirme, diante desses dispositivos legais, que o objeto mesmo do pacto comissório teria passado a ser lícito, no direito brasileiro; e que a cláusula seria válida "desde que concebida para produzir seus efeitos após o vencimento da dívida" ${ }^{256}$.

O trabalho de LIQUIDATO, ora citado, empreende análise dogmática rigorosa do contrato de penhor; tem grande valia e merece toda consideração. No entanto, o autêntico ambiente universitário deve suscitar o bom debate, fomentar o espírito crítico e convidar à contraposição de ideias. Disso decorre a importância de externar, com liberdade e franqueza, certas deficiências que, respeitosamente, julgase estarem presentes nos argumentos desse autor.

A primeira crítica a se fazer é a seguinte. Não se pode fechar os olhos para os parágrafos únicos dos artigos 1.365 e 1.428 do Código Civil, como parecem fazer certos autores e certa jurisprudência, identificados e corretamente criticados por LIQUIDATO $^{257}$. Contudo, é igualmente insustentável fazer tábua rasa da norma contida no caput desses mesmos dispositivos legais. A afirmação de que o objeto do pacto comissório, em si mesmo, seria lícito afronta o sentido literal das mencionadas normas, que estatuem sem rodeios a nulidade da cláusula. No direito brasileiro vigente, não se pode fazer afirmações gerais sobre a licitude do "objeto da cláusula comissória" sem que se dê igual ou maior atenção ao momento em que se manifesta o consenso do devedor sobre a transferência, ao credor, da titularidade do bem dado em garantia. Se esse consentimento é anterior ao vencimento da obrigação, a lei estabelece que o pacto é nulo. Se esse consentimento é posterior ao vencimento da obrigação, o acordo para dação em pagamento é tido pela lei como válido.

O segundo equívoco de LIQUIDATO, segundo aqui se entende, está em sustentar a validade da cláusula comissória "desde que concebida para produzir seus efeitos após o vencimento da dívida". Por definição, todo pacto comissório é concebido para gerar efeitos após o vencimento da dívida. É inextrincável da caracterização dessa cláusula a definição do inadimplemento como condição

256 A.G.N. LIQUIDATO. O contrato de penhor. p. 78-81 e 183-185; o trecho transcrito consta das p. 183-184.

${ }^{257}$ A.G.N. LIQUIDATO. O contrato de penhor. p. 70-71. 
suspensiva da transferência de titularidade do bem dado em garantia. O que não se concebe é um pacto comissório que não vise a, ou que "não seja concebido" para, produzir efeitos após o vencimento do débito. Repita-se: o critério determinante para a licitude da avença, segundo a letra da lei, é o momento em que o devedor expressa sua concordância com a transferência, ao credor, da titularidade do bem dado em garantia. Se essa concordância é manifestada antes do vencimento, não importa que ela "concebida para produzir seus efeitos após o vencimento da divida". Nesse caso, incidirá a regra do caput dos artigos 1.365 e 1.428 do Código Civil, não a dos respectivos parágrafos únicos.

Nesse aspecto, o Código Civil parece ter buscado se aproximar da disciplina do BGB que, como visto no capítulo 3, é convergente com as disposições do $\S 9^{\circ}$ do UCC a esse mesmo respeito. O $\S 1.229$ do $\mathrm{BGB}$, ao proibir o pacto comissório, estatui que a cláusula nula (nichtig) é aquela celebrada antes que se torne exigível o direito do credor de proceder à venda do bem dado em garantia. $\mathrm{O}$ direito de vender o bem empenhado, com vistas à obtenção do seu valor, constitui o conteúdo essencial do penhor, enquanto direito real de garantia ${ }^{258}$. A venda do bem, por sua vez, é $a$ forma legal exigida para a realização dessa garantia ( $§ 1.228$ do BGB). Sobre esse ponto, HEDEMANN explica que o pacto comissório é ilícito, antes de tudo, porque descaracteriza o penhor como um direito ao valor do bem empenhado, já que a cláusula pretende conferir ao credor um direito à substância desse mesmo bem ${ }^{259}$. No entanto, se há o vencimento, e a dívida não é paga, esse direito ao valor torna-se exigível, e se faz absoluta, no direito alemão, a prioridade que lhe assiste em relação aos direitos do próprio devedor e aos direitos dos demais credores.

Em que pese essa aparente aproximação com a disciplina do direito alemão, o fato é que o vencimento, sem adimplemento espontâneo, em nada afeta a eventual desproporção entre o valor de mercado do bem e o valor da dívida. Se esse

${ }^{258}$ Sobre o desenvolvimento desse aspecto no direito romano, em que o ius vendendi passou de elemento acidental para elemento fundamental do pignus, cf. A. BURDESE. Lex commissoria e ius vendendi nella fudicia e nel pignus.

${ }^{259}$ J.W. HedEMANN. Derechos reales. v. II. Version española de Jose Luis Diez Pastor y Manuel Gonzalez Enriquez. Madrid, Editorial Revista de Derecho Privado, 1955. p. 498. No mesmo sentido, M. WolfF. Tratado de derecho civil. Derecho de cosas. v. II. Trad. Blas Pérez González y José Alguer. Barcelona, Bosch, 1937. p. 425. 
descompasso de valores existia antes do vencimento, não há razões para se acreditar que o vencimento da obrigação, por si só, sublimará essa discrepância, ou que a tornará irrelevante. Se, por um lado, a lei deve assegurar a prioridade do credor titular de garantia real sobre o valor do bem dado em garantia, em particular após o vencimento, essa prioridade justifica-se somente até que se entregue ao credor o montante estritamente necessário ao adimplemento da dívida. Não há, aos olhos desta tese, qualquer justificativa para a apropriação de eventual excesso (dito superfluum) pelo credor garantido, em detrimento do devedor e dos demais credores, independentemente de essa apropriação ser acordada antes ou após o vencimento ${ }^{260}$. A circunstância de a veste jurídica dessa apropriação ser uma dação em pagamento, ou o efeito de um pacto comissório, não altera a verdade econômica e jurídica do que se passa na realidade.

Parece por isso haver uma tensão, senão uma contradição valorativa, entre as regras do art. 1.364, de um lado, e aquelas dos parágrafos únicos dos artigos 1.365 e 1.428, todos do Código Civil, de outro lado. A primeira norma estabelece que o credor titular de propriedade fiduciária é obrigado a vender a coisa alienada, judicial ou extrajudicialmente. Essa venda serve de crivo - ainda que imperfeito para que se determine, e se ateste, a adequação entre o valor de mercado do bem objeto da garantia e o valor da dívida garantida. Essa obrigação de vender é de certo modo contraditória com a permissão para a dação em pagamento, sem quaisquer restrições. A obrigação de venda representa uma barreira à apropriação do bem pelo credor por valor inferior ao de mercado, pois essa venda conta com a participação, potencial que seja, de terceiros. Esses terceiros, em princípio, não estão na posição de inferioridade daquele que contraiu empréstimo, ofereceu bem de sua propriedade em garantia e deixou de adimplir pontualmente a dívida. Na dação em pagamento, o consentimento que a engendra é resultado apenas do arranjo bilateral de interesses entre o credor e o devedor, sem qualquer interferência, nem ao mesmo potencial, de terceiros que não estejam sob a mesma premência do devedor.

Essa apropriação do superfluum pelo credor é especialmente indevida, e nociva, se o devedor cai em insolvência. Já se notou que, nos casos de falência e

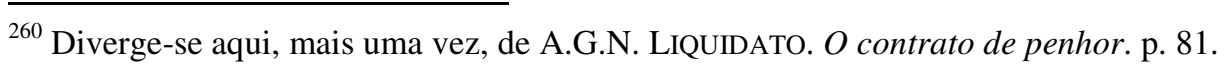


concurso civil de credores, não é absoluta, no direito brasileiro, a prioridade do credor garantido sobre o valor do bem a ele dado em garantia. Há diversas categorias de credores que, em caso de concurso falencial ou civil, têm direito de se verem satisfeitos com prioridade em relação aos titulares de garantias reais (item 4.5). Além disso, há outras categorias de credores que têm o direito de serem satisfeitos com o patrimônio do devedor de modo imediata ou mediatamente subsequente aos titulares de garantias reais, inclusive com uso do possível excesso que se apurar na comparação entre o valor de mercado do bem dado em garantia e o valor da dívida por ele garantida. Entre os credores a serem atendidos após os titulares de garantias reais, estão aqueles titulares de privilégios especiais e especiais e os quirografários. Estes últimos, via de regra, compreendem até mesmo os credores involuntários do devedor, isto é, aqueles que não escolheram ser credores, e podem ter adquirido essa condição em virtude de ilícitos extracontratuais praticados pelo devedor.

Há uma decisão legislativa no sentido que a exigência de concordância do devedor com a dação em pagamento, externada após o vencimento, seria suficiente para tutelar o interesse do próprio devedor ${ }^{261}$. Não se pode dizer o mesmo, porém, sobre os interesses dos demais credores do devedor. Se este vier à insolvência, a referida dação em pagamento - ao atribuir o provável excesso de valor apenas ao credor garantido - poderá subverter a par conditio creditorum. É por essa razão que: (i) o direito norte-americano condiciona a eficácia dessa dação em pagamento, posterior ao vencimento, não só ao consentimento, ou à ausência de oposição, do devedor, mas também de outros credores que possam ter interesses subordinados sobre o bem dado em garantia, que para tanto deverão ser notificados por escrito $\left(\S 9^{\circ}-620(\mathrm{~g})\right.$ do UCC); ${ }^{262}$; e (b) o direito francês, que passou a tolerar o pacto comissório nos casos em que o devedor é solvente, determina ineficácia dessa cláusula nas hipóteses de recuperação judicial ou falência (como visto no item 3.1.6).

\footnotetext{
${ }^{261}$ O que permanece sem explicação é o porquê de a lei olhar com desconfiança para a sinceridade dessa concordância antes do vencimento, impondo a nulidade do pacto comissório, e abandonar essa mesma desconfiança, logo após o vencimento, isto é, precisamente no momento em que o devedor está mais exposto às medidas coercitivas, jurídicas e não jurídicas, postas à disposição do credor para a proteção de seu crédito, como é o caso das ações judiciais de cobrança e de execução e, extrajudicialmente, os protestos e apontamentos do nome do devedor em órgãos de proteção ao crédito, entre outras.

${ }^{262}$ Além disso, se o devedor é consumidor, a dação em pagamento necessariamente deve quitar a totalidade da dívida, não se admitindo a remissão apenas parcial por essa via. A esse respeito, cf. L.M. LOPUCKI e E. WARREN. Secured credit. A Systems approach. p. 78-79.
} 
Se existe uma justificativa para que seja lícita a dação em pagamento do bem dado em garantia, após o vencimento, ela está relacionada com a prioridade do direito do credor ao valor do bem. Essa prioridade, porém, não pode ultrapassar o quanto necessário à pura e simples satisfação da dívida. Se o valor de mercado do bem supera o montante da dívida, nada justifica a apropriação desse excesso pelo credor, em prejuízo do devedor e dos demais credores. Se o devedor é solvente, cabe a ele acusar essa desproporção, e recusar o seu consenso para que se opere a dação em pagamento. Caso a concordância, manifestada após o vencimento, seja fruto de dolo, coação, lesão ou estado de necessidade, a dação em pagamento poderá ser anulada, tal como qualquer negócio jurídico celebrado nessas circunstâncias. Se a dívida adimplida por dação em pagamento refletir a cobrança de juros superiores aos legalmente admitidos, serão aplicáveis as regras repressoras da usura.

$\mathrm{Na}$ hipótese de o devedor tornar-se insolvente, entrarão em cena os direitos dos demais credores. Nesse caso, a dação em pagamento do bem antes dado em garantia - destituída de crivo isento sobre a adequação entre o valor do bem e o montante da dívida - deve ser tida por ineficaz, sob pena de ser violada a ordem cogente de prioridades e o regime de igualdade entre credores de mesma categoria, que devem imperar nos concursos de credores em geral. Existe um duplo fundamento legal para essa ineficácia, como se vê nos incisos II e IV do art. 129 da Lei de Falências. A dação em pagamento que preceder a falência do devedor: (a) constituirá forma de pagamento não prevista no contrato originalmente celebrado; se já estivesse prevista de antemão, estaria caracterizado o pacto comissório; e (b) conduzirá à atribuição patrimonial do excesso sobre o valor da dívida (dito superfluum) ao credor, o que implica a prática, pelo devedor, de ato a título gratuito. No primeiro caso (art. 129, inciso II, da Lei de Falências), será ineficaz a dação que tiver sido celebrada dentro do termo legal da falência, que não poderá retroagir a mais de noventa dias "contados do pedido de falência, do pedido de recuperação judicial ou do $1^{o}$ (primeiro) protesto por falta de pagamento, excluindo-se, para esta finalidade, os protestos que tenham sido cancelados" (art. 99, II, da Lei de Falências). No segundo caso (art. 129, inciso IV, da Lei de Falências), serão reputados ineficazes os atos a título gratuito praticados pelo devedor durante os dois anos anteriores à 
decretação da falência. Não há motivo para que essas regras não sejam igualmente aplicáveis à insolvência civil.

\subsection{Resumo do capítulo.}

Este capítulo 4 permitiu fossem alcançadas as seguintes conclusões, a respeito dos possíveis fundamentos da proibição do pacto comissório no direito brasileiro:

Proteção do devedor. A legislação vigente não permite que se afirme - como normalmente se faz - que o fundamento atual para a proibição do pacto comissório estaria na necessidade de proteção do devedor. Esta foi a justificativa histórica para que fosse estatuída a vedação, no período pós-clássico do direito romano. Apenas a inércia explica que se continue, nos dias que correm, a repeti-la, sem maior reflexão. A sanção aplicável à celebração do pacto comissório, com efeito, é a nulidade da cláusula; e o regime das nulidades, como se sabe, é reservado à tutela de interesses indisponíveis, insuscetíveis de confirmação e que não convalescem pelo transcurso do tempo. A posição de inferioridade, ou vulnerabilidade, que acomete o devedor na celebração do pacto comissório em nada se distingue, substancialmente, das hipóteses de lesão ou estado de necessidade. Para esses casos, a consequência prevista na lei é a anulabilidade da avença, não a sua nulidade. Até mesmo para os casos mais graves de dolo e coação, que implicam fraude e violência contra a pessoa, a resposta da lei é o regime das anulabilidades. Não há porque a mesmíssima justificativa da proteção do devedor - seja em situações mais graves (dolo, coação), seja em situações igualmente graves (lesão, estado de necessidade) - receber da ordem jurídica uma resposta tão distinta, isto é, a nulidade e não a anulabilidade; mesmo que ela se refira exclusivamente à cláusula, e não ao negócio jurídico como um todo. Por fim, o argumento da necessidade de proteção do devedor não se coaduna com o fato de que, após o vencimento, é lícita a dação em pagamento do bem objeto da garantia. Não se compreende, realmente, o porquê de o devedor ser merecedor de proteção antes do vencimento da dívida, e se poder abandoná-lo à própria sorte, ou à sorte do credor, logo após o vencimento. Se a debilidade do devedor muda após o vencimento, o mais razoável é crer que ela 
aumenta, e não que ela diminui, dadas as medidas judiciais e extrajudiciais de que o credor passa a dispor para a execução da dívida.

Repressão à usura. Embora o pacto comissório seja, em tese, apto a acobertar o negócio usurário, isso não decorre da estrutura, nem da função, dessa cláusula. A relação entre a usura e o pacto comissório é acidental e não necessária. A usura pode ter lugar em outras estruturas, que a legislação reconhece como lícitas e não sujeitas, a priori, a uma sanção de nulidade, como é o caso da compra e venda com pacto de retrovenda. Nada impede que o pacto comissório seja celebrado no contexto de um empréstimo em que as taxas de juros sejam condizentes com as limitações legais aplicáveis. Com o perdão da analogia chula, mas esclarecedora, fundamentar a proibição do pacto comissório na repressão à usura constitui procedimento semelhante a defender "que se tire o sofá da sala", sob a alegação de que nele tendem a ser praticados atos reprováveis. Com esse argumento, são ignorados os fatos, elementares, de que, na ausência do "sofá", os atos reprováveis podem continuar a ser praticados no recinto, com mais ou menos conforto; e que o "sofá" pode desempenhar outras tantas utilidades, que às mais das vezes nada tem de censuráveis. Esse argumento esbarra ainda na circunstância de que, no Brasil, a limitação das taxas de juros não atinge aqueles que emprestam profissionalmente, com autorização da autoridade monetária. Se o pacto comissório fosse um componente da repressão à usura, as instituições financeiras deveriam estar imunes a essa proibição, pois a lei e a jurisprudência dominante reconhecem, com tranquilidade, que esses credores profissionais não estão adstritos às limitações às taxas de juros que vigoram para a generalidade dos cidadãos e dos demais empresários. Em outras palavras, dizer que a vedação ao pacto comissório justificase pela necessidade de reprimir a usura teria o valor prático de autorizar apenas as instituições financeiras a celebrar pactos comissórios, o que não ocorre, nem faz sentido que ocorra. Tal como a justificativa anterior (proteção do devedor), a hipótese da repressão à usura também não se mostra coerente com a autorização legal para que, depois do vencimento, credor e devedor entrem em acordo sobre a dação em pagamento do bem objeto de garantia. Se - em função do valor de mercado do bem - a transferência de sua titularidade ao credor resulta na cobrança de juros superiores aos legalmente admitidos, isso em nada é afetado ou modificado pela 
circunstância de o consenso do devedor ser manifestado antes ou depois do vencimento. A usura que, nessa hipótese, supõe-se esteja implícita na celebração do pacto comissório desconhece qualquer alteração pelo tão só advento do vencimento, sem pagamento pontual. Se os juros são superiores aos legais, o vencimento torna a situação até mais perigosa, e não menos, dada a maior possibilidade de se coagir o devedor a pagá-los.

(Suposto) caráter inderrogável da via judicial, como forma de execução. Não há espaço, no direito brasileiro, para o argumento de que o pacto comissório, se lícito fosse, violaria um suposto caráter inderrogável da via judicial, como forma de execução. A legislação brasileira há décadas contempla hipóteses numerosas, largamente disseminadas e bastante variadas de execução que prescindem, em absoluto, do processo civil e da via judicial. Inexiste, portanto, no direito brasileiro, um princípio com esse conteúdo. Ao contrário, está assentado que, em um grande número de situações bastante corriqueiras e muito relevantes, o munus público de proceder à execução do comando, ou de deflagrar a sanção civil, é posto pela lei nas mãos do próprio interessado, ou de terceiros que lhe façam as vezes, sem que nisso se envolva ou precise ser envolvido o Poder Judiciário. O exercício dessa função pública por particulares em nada se diferencia do que já se passa: (a) no direito administrativo, como se vê nos casos de concessão de serviços públicos e delegação de poderes regulatórios às bolsas de valores, por exemplo, ou (b) mesmo no processo civil, em relação à função jurisdicional, como se vê no caso da arbitragem. Não reside nisso, portanto, a justificativa para a vedação do pacto comissório.

Interesse social em impedir a difusão do pacto comissório. Trata-se do fundamento construído em uma das mais relevantes monografias sobre o tema da proibição do pacto comissório, de autoria de BIANCA ${ }^{263}$. Em que pese a importância da obra, e a inegável autoridade que lhe assiste, o argumento não convence. Há nele o acerto de deslocar a questão para um interesse geral, capaz de explicar a sanção de nulidade. Todavia, não é correto dizer que existe um interesse geral em impedir que o pacto comissório se propague sem apontar, com igual ênfase, a quem, ou o que

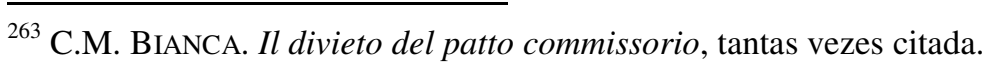


essa propagação prejudicaria. Os componentes desse alegado interesse geral, a que se refere BIANCA, não se diferenciam de uma concepção relativamente ampla do princípio da par conditio creditorum, ou da noção de garantia financeira dos créditos, de que fala BulHõEs PEDREIRA ${ }^{264}$. Por isso, cabe deitar maior atenção ao referido princípio.

Preservação da par conditio creditorum. De acordo com a Lei da Falências, e com as normas do Código Civil e do Código de Processo Civil que regem o concurso civil de credores, não é absoluta a prioridade, sobre o valor do bem, que assiste ao credor titular de garantia real, em caso de insolvência do devedor. Ao operar a realização imediata da garantia, em eventual contexto de insolvência do devedor, o pacto comissório, se lícito fosse, seria capaz de subverter a ordem de preferência dos créditos na falência e no concurso civil e, desse modo, ofender a par conditio creditorum. Isso se daria de dois modos, ao menos. Apropriando-se, pelo tão só inadimplemento, da titularidade do bem dado em garantia, o credor assim satisfeito poderia "passar à frente" de outros que, segundo a lei, deveriam ser atendidos com prioridade. Além disso, ao se tornar titular em definitivo do bem dado em garantia, sem que se atente para a efetiva adequação entre o valor de mercado desse bem e o montante da dívida garantida, pode haver prejuízo aos demais credores que, no concurso, deveriam ser atendidos de modo subsequente aos titulares de garantia real. É o caso, por exemplo, do Fisco (na falência), e dos titulares de privilégios especiais e gerais, e dos credores quirografários (tanto na falência como no concurso civil), dentre os quais geralmente se incluem até mesmo os credores involuntários do devedor. Trata-se, como se vê, de justificativa relacionada à tutela de interesses gerais e indisponíveis, capazes de justificar a sanção de nulidade que é prevista para a celebração do pacto comissório. No entanto, o fato é que - para a mesma finalidade - a legislação vigente vale-se do regime jurídico da ineficácia. É esta, realmente, a consequência jurídica aplicável às hipóteses de fraude contra credores, fraude à execução e também àquelas previstas no art. 129 da Lei de Falências. Este último dispositivo legal, em seus incisos II e IV, resolve a incongruência gerada pela autorização legal para que, após o vencimento, o credor e o devedor possam acordar a dação do bem dado em garantia em pagamento

264 J.L. BULHõEs PEDREIRA. Finanças e demonstrações financeira das companhia (conceitos fundamentais). p. 137-161. 
da dívida garantida. De acordo com essas normas, tal dação em pagamento pode ser declarada ineficaz, em caso de falência do devedor, caso se demonstre a ocorrência de prejuízo aos direitos dos demais credores, observados o termo legal, no caso do inciso II, e o prazo de dois anos a que se refere o inciso IV. É a única das justificativas estudadas que permite uma leitura coerente dos enunciados normativos contidos no caput e no parágrafo único dos artigos 1.365 e 1.428 do Código Civil.

\section{Reconstrução do sentido da proibição do pacto comissório, no direito}

brasileiro. Esta tese defende que o fundamento e o sentido da proibição do pacto comissório, no direito brasileiro, decorrem: (a) da licitude do pacto marciano; e (b) do direito reconhecido ao credor de ficar com o objeto da garantia, nos casos em que tal objeto já consiste, ou já está nominado, em dinheiro (penhor de créditos e de títulos de crédito, alienação fiduciária no mercado de capitais, liquidações de garantias no sistema brasileiro de pagamentos e os empréstimos feitos no âmbito do chamado crédito consignado). Essas permissões demonstram que o cerne da proibição do pacto comissório está em evitar que o credor se aproprie de eventual excesso que se verificar entre o valor de mercado do bem dado em garantia, no momento do vencimento da obrigação, e o valor da dívida. Por isso, a vedação cede diante: (i) da designação consensual, entre credor e devedor, um terceiro isento que avalie ou estime o valor de mercado do bem, após o vencimento (pacto marciano); e (ii) das garantias que já consistem, ou já estão nominadas, em dinheiro, pois o excesso, se houver, será imediatamente perceptível, e desse mero confronto decorrerá a responsabilidade do devedor pela insuficiência da garantia, ou a obrigação do credor de imediatamente restituir o excesso ao devedor, em benefício deste e de seus demais credores. Essas conclusões são convergentes com as investigações conduzidas no capítulo 2, no qual se verificou que a estrutura jurídica do pacto comissório opera a realização da garantia. Impõe-se um paralelismo, ou homologia, entre o pacto comissório e as formas coativas de excussão de bens no processo civil. Nesse último âmbito, a avaliação do bem penhorado é requisito imprescindível para a sua adjudicação pelo credor, no curso do processo, sendo obviamente desnecessária essa providência se o bem constrito for dinheiro. Em reforço a esses argumentos, deve-se mencionar que o direito luso-brasileiro, desde as Ordenações, e conforme refletido na Consolidação das Leis Civis, sempre admitiu a apropriação do bem 
objeto de garantia pelo credor, desde que isso ocorresse "pelo justo preço"; em substância, essa solução não diverge daquela consagrada no direito norte-americano, no direito alemão e no direito francês; nessas legislações, o direito do credor de proceder à venda privada do bem, inclusive para si mesmo, está condicionado à existência de cotações públicas de preço de mercado do bem dado em garantia; na ausência destas, obriga-se o credor a realizar a venda pública do bem, ou seja, exigese uma situação de publicidade e concorrência, ao menos potencial, com terceiros interessados, que busca evitar que o credor se aproprie do excesso que possa haver entre o valor de mercado do bem e o valor da dívida.

O porquê de ser lícita a dação em pagamento, posterior ao vencimento. A permissão contida nos parágrafos únicos dos artigos 1.365 e 1.428 do Código Civil está ligada à prioridade do credor garantido sobre $o$ valor do bem dado em garantia. Essa prioridade é limitada ao montante estritamente necessário ao pagamento do débito. Não existe justificativa para a apropriação de eventual excesso pelo credor, em prejuízo do devedor e dos demais credores. A lei atribui ao devedor o ônus de resistir a essa apropriação, nos casos em que ela for indevida, o que é aceitável se esse mesmo devedor for solvente. Se o devedor resiste, e se recusa a efetuar a dação em pagamento, a execução ocorrerá no âmbito do processo, no qual deverá ser realizada a avaliação do bem. Se o devedor consente com a dação, mas houve dolo, coação, lesão ou estado de necessidade, tal declaração será anulável, nos termos da lei. Sobrevindo, porém, a insolvência do devedor, o consentimento deste último, ainda que livremente manifestado, não bastará. Para a tutela dos direitos dos demais credores do devedor insolvente, a referida dação em pagamento deverá ser considerada ineficaz, com fundamento no art. 129, incisos II e IV, da Lei de Falências. No primeiro caso (inciso II), será ineficaz a dação praticada dentro do termo legal a que se refere o art. 99, inciso II, da Lei de Falências. No segundo caso (inciso IV), será ineficaz $\mathrm{o}$ ato gratuito praticado durante os dois anos que antecederem a decretação da falência. Essa necessidade de proteção dos interesses dos demais credores é reconhecida no direito norte-americano, no qual se exige a concordância de outros credores com direitos sobre o bem dado em garantia para que essa dação em pagamento surta efeitos. No direito francês, a autorização legal para a 
celebração de pacto comissório simplesmente deixa de existir se o devedor recorrer à salvaguarda equivalente à recuperação judicial, ou falir.

\subsection{Retorno às questões iniciais.}

Esta tese adotou, como pontos de partida, duas questões sobre o fundamento da proibição do pacto comissório (item 1.1), que foram: (a) qual o fundamento dessa vedação; e (b) diante desse fundamento, se ela deveria ficar restrita aos casos expressamente determinados pela lei, ou se deveria se estender a todas e quaisquer situações em que um direito funciona como garantia. A primeira pergunta, acredita-se, já foi respondida, por tudo o que se escreveu até o momento. A segunda precisa aqui ser revisitada.

Sobre ela, pode-se afirmar que o fundamento da proibição do pacto comissório não guarda pertinência apenas e tão somente com as garantias nominadas no Código Civil (penhor, hipoteca, anticrese e propriedade fiduciária). A ratio inerente à vedação está presente em toda e qualquer situação em que um bem integrante do patrimônio do devedor, ou de terceiro, é transferido ou dado em garantia de um débito. Assim, se existe um critério apto a guiar a delimitação do âmbito de incidência da proibição do pacto comissório, esse critério deve ser funcional, e não estrutural. Essa abordagem funcional, porém, coloca-se em choque, de certo modo, com a postura que a legislação brasileira adota em relação à fixação da ordem de prioridades dos credores em caso de insolvência do devedor. A proibição do pacto comissório está intimamente relacionada com a observância dessa ordem de prioridades.

No direito brasileiro, essa ordem de prioridades é predominantemente definida segundo critérios apenas estruturais ou estáticos. De modo geral, a propriedade predomina sobre os direitos reais de garantia, e estes prevalecem sobre os demais direitos pessoais. Isso tem levado a uma decidida preferência dos agentes de mercado pelas garantias fiduciárias que, por se vestirem de propriedade, gozam de tratamento privilegiado na recuperação judicial e na falência, em detrimento do penhor, da hipoteca e da anticrese, cujas posições no concurso de credores ficam 
comparativamente inferiorizadas. Ora, se todas essas estruturas jurídicas funcionam como garantias, as prioridades entre elas deveriam seguir, exclusivamente, critérios outros, mais diretamente ligados aos princípios e valores tutelados pela ordem jurídica e à política de crédito, e não tanto às características estruturais dos direitos envolvidos. O que justifica que um credor titular de alienação fiduciária de bem móvel ou imóvel tenha tratamento tão mais favorável do que um credor titular de penhor sobre bem móvel ou de hipoteca? Ou o que explica que um credor titular de cessão fiduciária de créditos seja tão favorecido no concurso de credores, em comparação com um credor que tenha celebrado penhor de créditos?

Dois exemplos desses critérios funcionais, vinculados a princípios e valores, e à política de crédito, são: (i) a prioridade dada à satisfação dos créditos trabalhistas no valor de até 150 salários mínimos (art. 83, I, da Lei de Falências); e (ii) a prioridade dada aos créditos dos fornecedores de bens e serviços, ou financiadores, que contratam com o devedor durante o processo de recuperação judicial (art. 67 da Lei de Falências) ${ }^{265}$. Tais critérios convivem, no entanto, com outros apenas estruturais, como é o caso daqueles que diferenciam os direitos reais e os direitos pessoais, sem atenção à função por eles desempenhada.

Essa desvinculação entre a estrutura das garantias, de um lado, e a sua posição no concurso singular ou coletivo correspondem, justamente, à diretriz adotada pelo legislador norte-americano, na elaboração do $\$ 9^{\circ}$ do UCC. Nesse diploma, as garantias são assim qualificadas por sua função ${ }^{266}$, e as prioridades são objeto de disciplina específica, sem relação direta com a estrutura da garantia ${ }^{267}$.

\footnotetext{
${ }^{265}$ Sobre o art. 83 da Lei de Falências, cf. os comentários de F. SATIRO DE SOUZA JR. e, sobre o art. 67, os de E.S. MuNHOZ, In: Comentários à lei de recuperação de empresas e falência (coord. Francisco Satiro de Souza Jr. e Antonio Sergio A. de Moraes Pitombo). $2^{\mathrm{a}}$ edição. São Paulo, Revista dos Tribunais, 2007. p. 357-369 e p. 317-318, respectivamente.

${ }^{266}$ G. GILMORE. Security interests in personal property. v. I. p. 333, onde se lê: "Under Article 9 the whole elaborated structure of technical limitations disappears: whatever other troubles a secured party may run into, he no longer has to make the often fastidious and complicated choice between conditional sale and chattel mortgage, trust receipt and factor's lien, and so on. On the other hand, it is no longer possible for him or his counsel to jockey for position by choosing a 'strong' device instead of a 'weak' one or to draft his way out of the statute by inventing a new device. Any transfer of property for security, and in addition certain sales of accounts, contract rights and chattel paper, will be within the Article and subject to its rules". Em tradução livre: "Sob o Article 9 a estrutura toda elaborada de limitações técnicas [às formas de garantia anteriores ao $\S 9^{\circ}$ do UCC] desaparecem: quaisquer que sejam os problemas que apareçam para o credor garantido, ele não mais tem a necessidade de fazer a intrincada e cansativa escolha entre uma venda com reserva de domínio ou uma chattel mortgage, trust receipt e factor's lien, e assim por diante. Por outro lado, não é mais possível a
} 
Uma, apenas uma, das questões que mereceria maior debate e reflexão, nessa reordenação valorativa e funcional das prioridades, é a situação dos credores involuntários. Não parece razoável que tais credores, que adquiriram essa condição sem escolha, sem qualquer intuito lucrativo, e como decorrência de ilícitos extracontratuais praticados pelo devedor, sejam considerados meros quirografários. É realmente difícil de aceitar que tais credores devam permanecer, como hoje estão, em posição de total subordinação aos credores que, profissional e conscientemente, e com finalidade lucrativa, escolheram se tornar credores do devedor.

A proposta de mudança legislativa, nessa direção de melhor proteger os credores involuntários, provavelmente seria combatida sob o argumento de que tornaria ainda mais onerosos os já caros juros bancários praticados no país ${ }^{268}$. É prematuro tomar posição firme a esse respeito, mas o fato é que se trata de um debate a ser provocado e enfrentado. Autores da maior importância, e que estão longe de menosprezar os reflexos econômicos das normas jurídicas, atacam, com vigor, a oponibilidade da regra da limitação de responsabilidade perante tais credores involuntários $^{269}$. Sob essa perspectiva, chega a ser quase tímido sugerir que tais

ele ou a seu advogado competir ou se acotovelar à frente de outros credores ao escolher uma garantia 'forte' em vez de uma 'fraca', ou de tentar escapar às regras do $\$ 9^{\circ}$ tentando inventar um novo mecanismo de garantia. Qualquer transferência de titularidade feita com finalidade de garantia e, adicionalmente, certas cessões de crédito, de direitos contratuais ou chattel paper, estarão compreendidas no âmbito de incidência do $\S 9^{\circ}$ e de suas regras". No mesmo sentido, cf. G. MCCORMACK. Secured credit and the harmonization of law. The UNCITRAL experience. Cheltenham/Northhampton, Edward Elgar, 2011. p. 81: "Article 9 abandons old distinctions between creating security over an asset and the use of absolute title to achieve the same economic objective. Article 9 adopts the universal generic concept of a security interest, and all the old terminology of the law such as pledge, mortgage, conditional sale, trust receipt etc. has been replaced by the unitary concept of a security interest". Em tradução livre: "O article 9 abandona a antiga distinção entre a criação de uma garantia sobre um bem e a transferência de propriedade plena para atingir o mesmo objetivo econômico. $\mathrm{O}$ article 9 adota o conceito genérico e universal de 'security interest', e toda a antiga terminologia jurídica do penhor, hipoteca, venda condicional, transferência em confiança, etc. foi substituída pelo conceito unitário de 'security interest'."

${ }^{267}$ H. SIGMAN. Security in movables in the United States - Uniform Commercial Code Article 9: a basis for comparison. In: Security Rights in Movable Property in European Private Law. Edited by Eva-Maria Kieninger. Cambridge: Cambridge University Press. 2009. p. 54-80. Cf. também G. GILMORE. Security interests in personal property. v. I. p. 288-308.

${ }^{268}$ De acordo com estudo da Associação Nacional dos Executivos de Finanças - Anefac, os juros cobrados de clientes pessoas físicas pelas instituições financeiras brasileiras, em média, fazem o valor da dívida dobrar a cada treze meses. No caso dos cartões de crédito, a dívida é multiplicada por dois em cerca de 7 meses. Cf. matéria de Yolanda Fordelone, publicada em O Estado de São Paulo. Edição de 12 de novembro de 2012. B-6. "Dívida não paga pode dobrar em menos de um ano".

${ }^{269} \mathrm{O}$ argumento é de J. ARMOUR, H. HANSMANN e R. KRAAKMAN. What is a corporation? In: The anatomy of corporate law. A comparative and functional approach. $2^{\text {nd }}$ edition. Oxford, Oxford 
credores permaneçam sujeitos à regra de limitação de responsabilidade, mas gozem ao menos de posição mais favorecida em eventual concurso de credores.

A ratio inerente à proibição do pacto comissório, de certo modo, colide com a disseminação de diferentes modalidades de propriedade fiduciária, que grassa no direito brasileiro. Existem hoje na legislação: (a) a disciplina geral da propriedade fiduciária, constante do Código Civil, que é aplicável a bens móveis e infungíveis, na qual vigora expressamente a vedação ao pacto comissório (art. 1.365) e que, em caso de inadimplemento, impõe ao credor a obrigação de vender o bem a terceiros (art. 1.364); (b) a alienação fiduciária de bens imóveis, regida pela Lei n. ${ }^{\circ}$ 9.514/97, na qual é expressamente prevista a consolidação da propriedade em nome do fiduciário, em caso de inadimplemento (art. 26), mas que também impõe ao fiduciário - de modo subsequente a essa consolidação - a obrigação de realizar dois leilões para a venda do bem a terceiros (art. 27); (c) a alienação e cessão fiduciárias celebradas no âmbito do mercado financeiro e de capitais, que podem ter por objeto bens móveis e fungíveis, assim como créditos e títulos de crédito, regida pelo art. 66B da Lei n. ${ }^{\circ}$ 4.728/65; nestas últimas modalidades, em caso de inadimplemento, a lei estabelece que o credor pode (rectius, deve) vender o bem a terceiros, independentemente de leilão, hasta ou qualquer medida judicial (art. 66-B, $\left.\$ 3^{\circ}\right)^{270}$; e (d) a alienação fiduciária que pode garantir os direitos do credor titular de Cédula de Produto Rural (art. 5 , inciso III, da Lei n. ${ }^{\circ}$ 8.929/94), que incide sobre bens fungíveis e à qual, se não tiver sido celebrada no âmbito do mercado financeiro e de capitais, serão aplicáveis as regras pertinentes do Código Civil ${ }^{271}$.

University Press, 2009. p. 11 e também o capítulo 5 da mesma obra, de autoria de J. ARMOUR, G. HERTIG e H. KANDA. Também sobre o tema dos chamados non-adjusting creditors, cf. H. HANSMANN e R. KRAAKMAN. Toward unlimited shareholder liability for corporate torts. 100 Yale Law Journal 1879 (1991) e L.A. BEBCHUK e J.M. FRIED. The uneasy case for the priority of secured claims in bankruptcy. 105 Yale Law Journal 857 (1996).

${ }^{270}$ A Lei n. ${ }^{\circ}$ 6.404/76, desde sua edição em 15 de dezembro de 1976, já permitia a alienação fiduciária de ações de emissão de companhias (artigos 40 e 113, parágrafo único).

${ }^{271}$ Em relação às operações de crédito para financiamento do agronegócio, deve ser mencionada também a regra do art. $21, \S 5^{\circ}$, da Lei n. ${ }^{\circ} 11.076$, de 30 de dezembro de 2004. Segundo ela, a apresentação concomitante, ao depositário, do Certificado de Depósito Agropecuário - CDA, acompanhado do Warrant Agropecuário, tem o efeito de tornar o endossatário proprietário do produto descrito nesses títulos. Sendo proprietário (e não credor), estará esse endossatário em princípio imune aos efeitos de eventual recuperação judicial do devedor e, em caso de falência, poderá se valer do pedido de restituição previsto no art. 85 da Lei de Falências. 
Em todos esses casos, a falência do devedor autorizará o credor proprietário que é - a formular pedido de restituição, nos termos do art. 85 da Lei de Falências. O objetivo declarado da lei, nesse ponto, foi o de estimular a concessão de crédito amparado por essas modalidades de garantia, assegurando ao credor uma espécie de imunidade ao concurso de credores, seja na falência, seja na insolvência civil $^{272}$. Parece haver aí, todavia, um exagero. Uma coisa é dar prioridade a determinadas categorias de credores. Outra, bem distinta, é garantir-lhes imunidade ao concurso de credores. Antes de ser proprietário fiduciário, o titular da garantia é um credor. Seus direitos sobre o bem objeto da garantia, são acessórios e estão limitados, em seu exercício, à função de adimplemento do débito. A solução do pedido de restituição integral do bem ou do respectivo valor ignora, por exemplo, que o falido já pode ter pagado parcela mais ou menos representativa da dívida, a qual, somada ao valor de mercado do bem restituído, pode suplantar o montante da dívida. Mesmo que a dívida toda esteja em aberto, também pode ocorrer de o valor de mercado do bem dado em garantia (fiduciária) ser-lhe superior. Enfim, mutatis mutandis, a atribuição do remédio representado pelo pedido de restituição aos titulares de propriedade fiduciária pode gerar as mesmas consequências deletérias do pacto comissório, conforme apontadas no item 4.5. Pode haver, em outras palavras, enriquecimento indevido do credor fiduciário, em detrimento dos direitos dos demais credores. Não há motivo justo ou razoabilidade em se permitir que o bem seja simplesmente restituído ao titular da garantia fiduciária, sem que se proceda à respectiva avaliação e sem que se verifique se há excesso em relação ao montante da dívida.

\subsection{Sugestões de aperfeiçoamento do direito vigente.}

Para rematar este capítulo 4, é oportuno identificar certas sugestões de aperfeiçoamento do direito vigente, baseadas no quanto exposto até aqui.

(a) Criar autorização legal expressa para a celebração do pacto marciano. A primeira sugestão é a de inserir, no Código Civil, autorização expressa

\footnotetext{
${ }^{272}$ Sobre as escolhas da Lei de Falência em favor dos grandes credores privados, cf. M. R. PENTEADO. Comentários às disposições preliminares da Lei n. ${ }^{\circ}$ 11.101/05. In: Comentários à lei de recuperação de empresas e falência (coord. Francisco Satiro de Souza Jr. e Antonio Sergio A. de Moraes Pitombo). $2^{a}$ edição. São Paulo, Revista dos Tribunais, 2007. p. 59-63.
} 
para a celebração do pacto marciano. Como visto, o pacto marciano tem foros de cidade na doutrina, na jurisprudência, nas legislações estrangeiras e também na tradição do direito luso-brasileiro. A existência de permissão explícita, na lei, incentivaria a sua adoção nos contratos de garantia, e ofereceria alternativa útil de excussão extrajudicial do bem dado em garantia, sem os inconvenientes que a proibição do pacto comissório visa a coibir (risco de apropriação do dito superfluum pelo credor garantido).

(b) Prever e disciplinar a venda, pública e privada, do bem dado em garantia, pelo credor garantido. Uma segunda modificação legislativa salutar - e condizente com os melhores exemplos estrangeiros - consiste em prevê e disciplinar em detalhe a venda extrajudicial, púbica ou privada, do bem dado em garantia, em caso de inadimplemento do devedor. Nessa disciplina, pode-se conferir ao próprio credor o munus de realizar a venda do bem, independentemente de existir previsão contratual a esse respeito, ou de outorga de mandato ou procuração para esse fim. Havendo cotações públicas e confiáveis sobre o valor de mercado do bem objeto da garantia, essa venda pode ocorrer privadamente, e o adquirente pode ser o próprio credor, que deverá prestar contas de seus atos, comparando o valor de mercado do bem com o montante da dívida. Na ausência dessas cotações, a venda deve ser pública, isto é, deve-se dar publicidade prévia e satisfatória à iniciativa de alienação e se deve garantir a avaliação isenta do valor de mercado do bem, de modo posterior ao vencimento. Da mesma forma, é conveniente exigir que o credor preste contas dos atos por ele realizados, podendo ser responsabilizado pelos atos abusivos ou ilícitos que cometer, seja por iniciativa do devedor ou de seus demais credores. A venda judicial tende a diminuir o valor que efetivamente se extrai do bem, o que prejudica em primeiro lugar o devedor, que permanece responsável por esse déficit. Um indicativo disso é que, na jurisprudência do STJ, o preço reputado vil é aquele inferior em mais de $50 \%$ ao montante indicado na avaliação; em outras palavras, descontos de até $50 \%$ no valor de avaliação são normalmente tolerados pelos tribunais $^{273}$. Por isso, tanto quanto possível, a venda do bem garantido deve

273 Exemplificativamente, Agravo Regimental no Agravo em Recurso Especial 98.664/RS, Quarta Turma, Min. Maria Isabel Galotti, j. 06.09.2012, p. 17.09.2012, consultado em www.stj.gov.br, acesso em 25.11.2012, em cuja ementa se lê: “O STJ entende que está caracterizado o preço vil quando o valor da arrematação for inferior a $50 \%$ da avaliação do bem, o que não ocorre nos autos do processo, em que o valor mínimo fixado pelas instâncias ordinárias é superior a esse percentual”. 
mimetizar ou reproduzir condições usuais de mercado. $\mathrm{O}$ favorecimento legal à adjudicação, hoje presente no Código de Processo Civil (art. 685-A e seguintes), gera um incentivo para que a alienação se dê em dois tempos. Na primeira fase, o credor adjudica o bem a si, dentro do processo, pelo valor mínimo da avaliação. Em seguida, já de propriedade do bem, tem liberdade de realizar a venda em condições usuais de mercado ${ }^{274}$. Por fim, em contrapartida a esse procedimento extrajudicial mais ágil e facilitador da excussão da garantia, é igualmente razoável garantir ao devedor o direito de ver abatido do montante do débito o referido valor de mercado do bem, conforme indicado nas cotações púbicas disponíveis, ou nas avaliações isentas realizadas. Esse abatimento pelo valor de mercado pode ser estatuído independentemente da sua efetiva obtenção pelo credor, na situação concreta de venda. De fato, a experiência demonstra que raramente uma venda judicial ou forçada do bem resulta no pagamento do preço de mercado. O mercado impõe uma espécie de desconto ou abatimento pelo fato de se tratar de um procedimento coativo e sujeito a questionamentos ${ }^{275}$. Daí a conveniência de (a) por um lado, incrementar a agilidade dos mecanismos de excussão, em benefício do credor; mas (b) por outro lado, proteger o devedor contra a situação de permanência do déficit, em contrapartida a essa excussão agilizada.

\footnotetext{
${ }^{274}$ É o que relatam L.M. LOPUCKI e E. WARREN. Secured credit. A systems approach. p. 74: "In fact, purchase by the foreclosing creditor for later resale is by far the dominant pattern in mortgage foreclosures. A study of mortgage foreclosures in one county in New York revealed that the mortgagee purchased the property by credit bid in 77 percent of all cases. Eighty-five percent of the creditorpurchasers resold the property within four to five years, and a large majority of the resales took place in the first two years." Em tradução livre: "De fato, a compra pelo credor exequente para posterior revenda é de longe o padrão de conduta que predomina nas execuções hipotecárias. Um estudo das execuções hipotecárias em um condado de Nova Iorque revelou que o credor hipotecário adquiriu o bem hipotecado por adjudicação em $77 \%$ dos casos. $85 \%$ dos credores-adquirentes revenderam o bem em período de quatro a cinco anos e uma grossa maioria das revendas ocorrem nos primeiros dois anos". A referência é feita ao estudo de WECHSLER, Through the looking glass: foreclosure by sale as de facto strict foreclosure - An empirical study of mortgage foreclosure and subsequent resale. 70 Cornell Law Review 850 (1985).

${ }^{275}$ L.M. LOPUCKI e E. WARREN. Secured credit. A systems approach. p. 71: "Foreclosure sales rarely yield the 'market value' of the property - the amount it would bring in a sale by a willing buyer to a willing seller, neither of whom was under compulsion. Instead, they yield prices that reflect the adverse conditions under which they are held. This often leaves the debtor owning a deficiency." Em tradução livre: "Execuções raramente rendem o valor de mercado do bem - o valor que seria levantado em uma venda a um comprador interessado por um vendedor interessado, em que nenhum deles está sob a coerção das circunstâncias da dívida. Em lugar disso, elas rendem preços que refletem as condições adversas em que elas ocorrem. Isso geralmente deixa o devedor responsável pelo déficit que acaba por ser apurado". Nos Estados Unidos, há leis estaduais que procuram proteger os devedores contra esses déficit, conhecidas justamente como "antideficiency statutes".
} 
(c) Esclarecer que a autorização para dação, do bem objeto de garantia, em pagamento da dívida, aplica-se apenas ao devedor solvente. Exigir que essa dação seja precedida de avaliação do valor de mercado do bem. A lei deveria explicitar que as autorizações contidas nos parágrafos únicos dos artigos 1.365 e 1.428 do Código Civil aplicam-se exclusivamente aos devedores solventes. Deveria também estabelecer que, em qualquer hipótese, ela precisa ser precedida de avaliação do bem dado em pagamento, posterior ao vencimento. Essa avaliação, que seria desnecessária nos casos em que o preço do bem tiver cotação pública confiável, destina-se a mitigar o risco de desproporção entre o valor do bem e o montante da dívida. Sendo verificada, na avaliação, excesso do valor de mercado do bem dado em garantia sobre o montante da dívida, deve ser expressamente atribuído ao credor que adquirir o bem o dever de restituí-lo de imediato ao devedor, em benefício deste e de seus demais credores, a exemplo da obrigação de depósito da diferença prevista no art. 685-A, $\S 1^{\circ}$, do Código de Processo Civil. Caberia, por fim, indicar que se o devedor cair em insolvência, a dação em pagamento realizada estará sujeita às disposições do art. 129, II e IV, da Lei de Falências.

(d) Uniformizar a disciplina da excussão extrajudicial de todas as formas de garantia, segundo sua função. As sugestões feitas nos itens (a) a (c) deveriam contemplar todas as formas de garantia, independentemente de sua estrutura jurídica. A lei deveria determinar, realmente, que tais regras seriam aplicáveis às garantias nominadas no Código Civil (penhor, hipoteca, anticrese e propriedade fiduciária), às garantias previstas na legislação extravagante e ainda a eventuais garantias típicas ou atípicas, criadas no curso da atividade negocial. Devem ser mantidas, no entanto, as atuais regras de excussão pertinentes às garantias que já consistem em dinheiro ou títulos nominados em dinheiro.

(e) Revisão dos critérios de determinação das prioridades em caso de falência e concurso de credores. Outra sugestão refere-se à revisão crítica dos critérios que determinam as prioridades dos credores em caso de falência e concurso de credores. Atualmente, dá-se importância excessiva a aspectos estruturais dos direitos envolvidos: a propriedade, ainda que fiduciária, predomina sobre os direitos reais de garantia, e estes predominam sobre os direitos pessoais em geral. Isso acontece em detrimento das funções econômicas e sociais que esses direitos 
cumprem, que não raramente são as mesmas. Em suma, seria conveniente que as prioridades dos credores, diante da insolvência do devedor, estivessem mais diretamente ligadas aos princípios e valores tutelados pela ordem jurídica e à política de crédito, o que hoje acontece apenas em parte. Um dos problemas a serem considerados, nesse particular, é o dos credores involuntários, que mereceriam tratamento mais protetivo em comparação com os credores que, com atuação profissional e objetivos lucrativos, escolheram se tornar credores do devedor insolvente.

(f) Revisão da posição, na falência, dos titulares de garantias fiduciárias. É criticável a decisão, refletida na Lei de Falências, de tornar os titulares de garantias fiduciárias simplesmente imunes ao concurso de credores. Antes de serem proprietários fiduciários, eles são credores. Como tal, não têm direito a receber mais do que o valor atualizado da dívida. Assim, a ratio da proibição do pacto comissório impõe que o atendimento, ainda que prioritário, dos respectivos direitos não pode prescindir da comparação entre o saldo devedor do empréstimo e o valor de mercado do bem objeto da garantia. Se houver excesso, a eventual restituição ou o pagamento, conforme o caso, devem ser necessariamente acompanhados do depósito, pelo credor, da diferença apurada, em benefício da massa e dos demais credores, em sintonia com a regra do art. 685-A, $\S 1^{\circ}$, do Código de Processo Civil. 


\section{A PROIBIÇÃO DO PACTO COMISSÓRIO NA JURISPRUDÊNCIA DOS TRIBUNAIS SUPERIORES BRASILEIROS.}

\subsection{Escopo e plano do capítulo.}

Propondo-se a estudar proibição do pacto comissório no direito brasileiro, este tese não poderia ignorar o tratamento dado ao tema pelos tribunais superiores. A esse respeito, o objeto de estudo é recortado de modo a se concentrar, exclusivamente, nas decisões da instância especial, isto é, daquela que tem a incumbência de uniformizar a aplicação da lei federal. Serão assim discutidos, neste capítulo 5, os acórdãos que cuidaram da proibição do pacto comissório: (a) no âmbito do STF, que se qualificava como instância especial antes da promulgação da Constituição Federal de 1988 (item 5.2), e (b) do STJ, que desde então assumiu esse posto (item 5.3).

\subsection{As decisões do STF.}

Há um conjunto rico de acórdãos do STF que, durante as décadas de 1960, 1970 e 1980, debateram a extensão da proibição do pacto comissório. A leitura dessas decisões permite identificar dois momentos bastante distintos, nos quais foram diferentes as posições dominantes sobre o problema.

A primeira orientação do STF, por assim dizer, vigorou aproximadamente entre 1966 e 1973. O acórdão mais emblemático desse período é aquele proferido nos autos do Recurso Extraordinário n. ${ }^{\circ} 60.699 / \mathrm{GB}^{276}$. A diretriz

\footnotetext{
${ }^{276}$ STF. Segunda Turma. Rel. Min. Aliomar Baleeiro. j. 8.11.1966. RTJ 42/331. Pouco antes dessa decisão, o tema fora tangenciado no julgamento do Recurso Extraordinário n. ${ }^{\circ}$ 58.072/SP, Rel. Min. Evandro Lins e Silva, j. 25.05.1965. RTJ 33/554. Nesse último acórdão, porém, o tribunal limita-se a afirmar que a fundamentação estava toda ela baseada na análise fatos e provas, o que impedia a sua revisão pela instância especial. O resultado prático do não conhecimento do recurso, cumpre notar, foi a manutenção da decisão do Tribunal de Justiça do Estado de São Paulo no sentido de que incorreu em fraude a lei, por ofensa ao art. 765 do Código Civil então vigente, o negócio pretensamente fiduciário pelo qual se visa a alcançar o efeito prático típico do pacto comissório.
} 
estabelecida nessa decisão foi seguida pelo tribunal nos julgamentos dos Recursos Extraordinários n. ${ }^{\circ}$ 63.128/SP ${ }^{277}$ e n. ${ }^{\circ} 70.497 / \mathrm{RS}^{278}$.

Em 1973, o STF muda seu entendimento sobre o assunto, ao julgar o Recurso Extraordinário n. ${ }^{\circ} 71.616 / \mathrm{SP}^{279}$. A este se segue a alentada decisão do Recurso Extraordinário n. ${ }^{\circ}$ 82.447/SP ${ }^{280}$, que passa então a servir de principal referência para o quanto decidido no âmbito dos Recursos Extraordinários n. ${ }^{\circ}$ $85.156 / \mathrm{PR}^{281}, 86.981 / \mathrm{PR}^{282}, 90.648 / \mathrm{SP}^{283}$ e $98.947 / \mathrm{PR}^{284}$.

\subsubsection{Recurso Extraordinário n. ${ }^{\circ}$ 60.699/GB.}

Esse acórdão é dos mais fascinantes na discussão dos problemas inerentes à proibição do pacto comissório. Ficou nele documentado um vivo e atento debate entre os ministros, no qual se sobressaiu o raciocínio sensível e agudo do relator, Min. Aliomar Baleeiro.

Os fatos, em síntese, foram os seguintes: por força de relações comerciais entre Costa Representações Ltda. e Dianda Lopez \& Cia. Ltda., a primeira reconhecia-se devedora da segunda, do valor de $\mathrm{Cr} \$ 1.800 .000,00$, sujeitos a juros legais de $12 \%$ ao ano. Para garantir o pagamento desse débito, o sócio da devedora, Sr. Luiz da Silva Costa, e sua mulher, outorgaram à sociedade credora escritura de cessão de direitos de aquisição de determinados terrenos, situados no Município de Duque de Caxias. Na mesma data da celebração da escritura pública de cessão de direitos, as partes firmaram também documento particular, minutado pelos advogados da devedora, no qual constava (a) que se o débito de $\mathrm{Cr} \$ 1.800 .00,00$,

\footnotetext{
${ }^{277}$ STF. Terceira Turma. Rel. Min. Hermes Lima. j. 8.3.1968. RTJ 45/484.

${ }^{278}$ STF. Primeira Turma. Rel. Min. Luiz Galotti. j. 3.9.1970. RTJ 55/801.

279 STF. Primeira Turma. Rel. Min. Rodrigues Alckmin. j. 11.12.1973. Consultado em www.stf.gov.br.; acesso em 30.10.2009.

${ }^{280}$ STF. Segunda Turma. Rel. Min. Cordeiro Guerra, j. 8.6.1976. Consultado em www.stf.gov.br.; acesso em 30.10.2009.

${ }^{281}$ STF. Primeira Turma. Rel. Min. Cunha Peixoto. j. 16.2.1979. Consultado em www.stf.gov.br.; acesso em 30.10.2009.

${ }^{282}$ STF. Primeira Turma. Rel. Min. Cunha Peixoto. J. 21.11.1978. Consultado em www.stf.gov.br.; acesso em 30.10.2009.

${ }^{283}$ STF. Primeira Turma. Rel. Min. Soares Muñoz, j. 8.5.1979. Consultado em www.stf.gov.br.; acesso em 30.10.2009.

${ }^{284}$ STF. Primeira Turma. Rel. Min. Alfredo Buzaid, j. 22.6.1984. Consultado em www.stf.gov.br.; acesso em 30.10.2009.
} 
acrescido de juros, fosse pago por Costa Representações Ltda. a Dianda Lopez \& Cia. Ltda., dentro de determinado prazo, esta última ficaria obrigada a transferir de volta os direitos de aquisição sobre os terrenos ao Sr. Luiz da Silva Costa e à sua mulher; e (b) que a credora autorizava o Sr. Luiz da Silva Costa a processar a venda dos referidos imóveis, "dando seu assentimento (sic), desde que seja por importância que dê para pagar-lhe o total da dívida ora confessada, mais juros e despesas e desde que esse pagamento se realize de uma só vez, no ato da escritura". A escritura pública e o instrumento particular datavam de 19 de agosto de 1964. Depois da assinatura desses documentos, o Sr. Luiz da Silva Costa e sua mulher ajuizaram ação requerendo fosse declarada a "inexistência" do direito de Dianda Lopez \& Cia. Ltda. de ficar com os direitos sobre os terrenos em apreço, com fundamento no art. 765 do Código Civil então vigente.

Em pouco mais de dois anos da celebração dos negócios jurídicos, a ação foi julgada improcedente em primeira instância, essa decisão foi confirmada pelo tribunal estadual e o caso foi definitivamente julgado pelo STF, em 8 de novembro de 1966. No voto condutor, o Min. Aliomar Baleeiro conhece e dá provimento ao recurso, revertendo as decisões de primeira e segunda instâncias. Os principais fundamentos por ele adotados foram os seguintes (i) conquanto possa ser lícita a celebração de negócios fiduciários, eles não podem constituir caminho para se contornar a vedação do pacto comissório, que se qualifica como "princípio de ordem pública"; (ii) por isso, a alienação fiduciária prevista na Lei n. ${ }^{\circ}$ 4.728/65 determinava que, em caso de inadimplemento, cabia ao credor a obrigação de vender o bem, para imputar o preço assim obtido ao pagamento do débito; (iii) o negócio entabulado entre as partes assemelhava-se à caução de títulos ou direitos e deveria, por força de analogia, reger-se pela mesma disciplina do penhor (art. $4^{\circ}$ da Lei de Introdução ao Código Civil). Com base nesses argumentos, o relator ponderou que:

"a obrigação de vender a coisa nestes autos foi reconhecida pela recorrida na contestação. (...) Foi o que pediram os Recorrentes na ação declaratória. Dou provimento exclusivamente para isso, ressalvado o direito da Recorrida ao preço, na medida em que possa imputá-lo à dívida”. 
Além dessa, há outras manifestações do Min. Aliomar Baleeiro, no curso do julgamento, que merecem transcrição:

"Não sei se os eminentes Ministros notaram, nos jornais ('o jornal é uma janela aberta sobre a vida'), que há sujeitos que anunciam: 'empresto dinheiro sob hipoteca e também com pacto de retrovenda'. Pois bem é muito comum simular-se a hipoteca num pacto de retrovenda, para maior desembaraço do credor. Se o devedor não paga, ele fica logo com o bem".

“Não tive a impressão de que houvesse um propósito de não pagar ou de não cumprir a obrigação contratual. (...) O recorrente não pede a ineficácia da estipulação, pede que fique declarado que, em hipótese nenhuma, o credor fique com a coisa, para pagar-se, sem acordo ou hasta pública".

"E parece que pela maneira como se deu não há velhacaria. O que há é que se está procurando um caminho muito complicado para constituir-se uma garantia."

"A minha conclusão é a de que ele não pode ficar com os terrenos, como se efetiva a cessão. Se o devedor não pagar, ele tem de vendelos. Aliás, o credor concordou mais ou menos com isso nos autos"

"Sim, [conheço e dou provimento ao recurso] para que o credor não possa ficar com a coisa, para que não se possa locupletar de maneira nenhuma. Pode ser que com a inflação esse terreno deva valer muito hoje, porque sabemos que com ela qualquer terreno vale muito mais atualmente. Na hora do aperto, da agonia, o devedor entregou-o ao credor, tanto assim que este disse que não queria ficar com a coisa, mas apenas deseja ser pago". 
Essa visão não foi unânime. O Min. Pedro Chaves, antecipando argumento que, mais à frente, ganharia força no tribunal, votou pelo não conhecimento do recurso. Entendeu ele que a regra do art. 765 do Código Civil de 1916, por seus próprios termos, vigorava nos casos de hipoteca, penhor ou anticrese. $\mathrm{Na}$ hipótese dos autos, não estava envolvido nenhum desses direitos reais de garantia, o que impedia fosse invocada a proibição do pacto comissório. Preocupava o Min. Pedro Chaves o risco de a procedência do recurso abrir caminho para o devedor deixasse de pagar a dívida e frustrasse a garantia do credor. A esses argumentos, o relator respondeu que havia, na espécie, uma hipoteca dissimulada sob a cessão de direitos, e que o provimento do recurso era apenas para que se declarasse a necessidade de ser procedida a venda dos terrenos, impedindo-se que o credor simplesmente ficasse com o bem, por ocasião do inadimplemento.

É digno de nota que, nessa ocasião, o STF tenha identificado com muita clareza o risco de desproporção entre o valor de mercado do bem, no momento do vencimento da obrigação, e o valor da dívida. Merece ser sublinhado, ainda, que: (a) os juros respeitavam, no caso, o limite legal, o que demonstra a inexistência de relação necessária entre a proibição do pacto comissório e a repressão à usura; e (b) devedor e credor concordavam, no caso, que a solução devida era a venda do bem a terceiros, para que com isso fossem obtidos recursos para saldar a dívida e se pudesse entregar o provável excesso ao devedor. A interferência do Poder Judiciário restringiu-se à declaração de que o credor não poderia simplesmente "ficar com" a titularidade dos direitos à aquisição dos terrenos, e tinha, portanto, a obrigação de vendê-los para fins de satisfação da dívida e entrega de eventual excesso ao devedor.

\subsubsection{Recurso Extraordinário n. ${ }^{\circ}$ 63.128/SP.}

Este segundo acórdão, em comparação com o primeiro, é menos permeado por argumentos e debates. Os fatos, porém, eram muito semelhantes. Em resumo: o devedor e sua mulher outorgaram escritura de promessa de venda de bens imóveis a credor pessoa física. Pelas cláusulas que asseguravam, aos devedores, o direito de reaver o bem cuja transferência assim se compromissava, extraia-se sem 
muita dificuldade que a finalidade da transferência era a garantia do débito. Vencida a dívida, sem adimplemento, o credor buscou a adjudicação compulsória.

Foi ventilado, nos autos, o argumento de que a proibição do pacto comissório estaria restrita às hipóteses expressamente previstas no Código Civil (hipoteca, penhor e anticrese) e que não poderia ser aplicada no caso de compromisso de venda e compra de imóvel. O relator Min. Hermes Lima, com bastante convicção, rechaçou essa tese, sustentando que a promessa de venda e compra em verdade dissimulava empréstimo cuja garantia - vestida de adjudicação compulsória - ofendia o art. 765 do Código Civil então vigente. O trecho mais elucidativo do acórdão é o que se transcreve a seguir:

"Houve um contrato de venda e compra que dissimulou um empréstimo em dinheiro e através do qual o credor se adjudicaria o objeto da garantia, independente [sic] de execução de seu crédito. $O$ pacto comissório é legalmente proibido por força de razões sociais que a lei protege".

A decisão, como se vê, parece tangenciar o argumento de que o pacto comissório violaria o caráter inderrogável da via judicial, como forma de execução do crédito. $\mathrm{O}$ voto do relator afirma ainda que as razões para a proibição do pacto comissório transcendem a tutela individual do devedor, estando ligada a "razões sociais que a lei protege".

\subsubsection{Recurso Extraordinário n. ${ }^{\circ}$ 70.497/RS.}

Este terceiro caso praticamente não se diferencia dos demais. Os fatos, em síntese, foram os seguintes: em 25 de maio de 1966, foi celebrada, em Porto Alegre, escritura pública de promessa de venda e compra de apartamento situado na Rua 24 de Outubro, Bairro Independência, pelo preço de $\mathrm{Cr} \$ 6.000 .000,00$. Avençou-se que, nos quatro meses seguintes, os promitentes vendedores poderiam arrepender-se do negócio, desde que devolvessem as quantias até então pagas. Mesmo quitado o preço aplicável à transferência imobiliária assim formalizada, os 
promitentes vendedores continuavam na posse do apartamento. Terminado o prazo acordado sem o exercício do referido direito de arrependimento, o promitente comprador aforou ação de adjudicação compulsória, julgada procedente em primeira e segunda instâncias. Relata-se que tais decisões teriam se fundamentado na ausência de prova de que a promessa pretendia simular um mútuo, no qual eram cobrados juros superiores aos legalmente admitidos.

Os recorrentes apresentaram, nos autos, avaliação do apartamento que lhe atribuía o valor de $\mathrm{NCr} \$ 23.600,00$ (houve mudança da moeda, com o recorrente corte de três casas decimais, os famosos "três zeros"), o que seria forte prova de que se buscava encobrir o pacto comissório. Em outras palavras, e considerados os valores mencionados na decisão, o imóvel teria sido avaliado em montante quase quatro vezes superior ao valor do débito original. Somada à previsão contratual de direito de arrependimento, e à continuidade dos vendedores na posse do imóvel, essa circunstância convenceu o relator, Min. Luiz Galotti, de que se tratava realmente de uma simulação, que não poderia prosperar. Apontou o voto condutor que o próprio promitente comprador, por diversas vezes, acabava por se referir à dívida dos promitentes vendedores, indicando que o negócio principal efetivamente celebrado era de empréstimo. A despeito das inúmeras questões factuais e probatórias envolvidas, o STF não se esquivou de reformar o acórdão recorrido. Sustentou que era cabível o conhecimento do recurso, dada a violação ao critério legal de valorização das provas. Foi advogado do recorrente o Dr. Galeno Lacerda. Entre a celebração do negócio jurídico, de um lado, e o julgamento do STF, de outro, passaram-se pouco mais de quatro anos.

\subsubsection{Recurso Extraordinário n. ${ }^{0}$ 71.616/SP.}

Esse acórdão representa o ponto de inflexão na jurisprudência do STF sobre a matéria. Trata-se de decisão que procurou se apoiar no pensamento de MoReIRA Alves, antes mesmo de esse autor passar a compor o tribunal, o que em breve aconteceria. 
Os fatos: em 1957, foi celebrado compromisso de compra e venda de bem imóvel residencial, situado na Rua Nicarágua n. ${ }^{\circ}$ 58, na capital do Estado de São Paulo, bem como de um outro terreno, tudo por um preço único de $\mathrm{NCr} \$ 8.000,00$. Embora o preço estabelecido no compromisso estivesse desde o início quitado, os vendedores continuavam na posse do bem. Os compradores, após certo tempo, ajuizaram ação de reintegração de posse, tendo sido propostas, de lado a lado, outras demandas. Apesar de ter sido inicialmente deferida a liminar para reintegração na posse, a demanda, no mérito, foi julgada improcedente. Em apelação, a improcedência foi mantida. Diante disso, os vendedores intentaram ação rescisória do acórdão que confirmara a procedência da ação possessória, sob o argumento de que teria sido afrontada disposição literal da lei. A principal afronta perpetrada pela sentença, segundo alegado, teria consistido em recusar validade a negócio jurídico fiduciário, que não se confundiria com simulação fraudulenta. Ainda segundo essa argumentação, o negócio fiduciário é real, seus efeitos são sincera e honestamente buscados pelas partes e não se aplica a ele a vedação ao pacto comissório. A ação rescisória foi julgada procedente e, após a apelação, o processo seguiu ao STF. O recurso teve como um dos fundamentos de sua admissão a dissonância em relação ao quanto decidido nos autos do Recurso Extraordinário 60.699/GB, relatado pelo Min. Aliomar Baleeiro (item 5.2.1).

O relator Min. Rodrigues Alckmin resume com precisão o cerne da disputa, nos seguintes termos:

"negócio pelo qual o vendedor promete transferir o domínio, estipule, do mesmo passo, que estará autorizado a vender a outrem o bem pelo mesmo preço da promessa, ou maior, dentro de determinado prazo, retendo a seu favor qualquer quantia que exceda esse preço, incide na proibição do pacto comissório? Frise-se que se não trata de simulação de promessa de venda, ou de promessa com cláusula de desfazimento do negócio dentro de certo prazo, com a devolução do preço". 
A argumentação desenvolvida pelo voto condutor é longa, acaba por se amalgamar com a fundamentação do acórdão recorrido e se escora em diferentes contribuições doutrinárias. Seus principais pontos de apoio foram os seguintes: (a) a cessão e transferência, em garantia, de direitos decorrentes de compromisso de compra e venda de bem imóvel importa negócio fiduciário, não simulado nem fraudulento, ao qual não se aplica a proibição do pacto comissório; (b) conforme nota PONTES DE MIRANDA, seria um contrassenso pretender aplicar a vedação do pacto comissório àquele que adquire propriedade, ainda que para fins de garantia - pois “não se poderia negar tornar-se aquilo que ele já é. Pode-se vedar o vir a ser, não o ser" ${ }^{285}$; e (c) há uma diferença estrutural decisiva entre direitos reais de garantia (penhor, hipoteca, anticrese e também a alienação fiduciária em garantia, conforme então disciplinada pela Lei n. ${ }^{\circ}$ 4.728/65) e os direitos reais em garantia, que são direitos reais plenos; por isso, ainda que a propriedade seja transmitida para fins de garantia, o adquirente é dominus pleno, sendo inviável cogitar de se lhe aplicar a proibição do pacto comissório ${ }^{286}$. No mais, o que consta do acórdão é farta citação de excertos doutrinários que visam extremar o negócio fiduciário (lícito) dos negócios fraudulentos e simulados (ilícitos).

É interessante notar o grande esforço feito pelo relator para diferenciar a hipótese dos autos daquelas apreciadas nos três primeiros recursos extraordinários tratados neste capítulo 5. Esforço inglório. O tribunal de fato mudou seu posicionamento, pois os casos são essencialmente iguais. A única diferença, talvez, seja a inexistência, na espécie, de cláusula que permitisse o puro e simples retorno do bem ao patrimônio dos vendedores, mediante o pagamento de certa quantia (retrovenda típica). Mas isso não muda a verdade de que se admitiu, em outras palavras, que o proprietário que adquirira essa condição em caráter fiduciário ficasse em definitivo nessa posição, por força do inadimplemento de uma dívida. Chegou a ser arguida, pela Procuradoria Geral da República, a existência de desproporção entre o débito e o valor do bem. Esse ponto, porém, foi afastado pelo relator com base na circunstância de que o devedor não conseguiu encontrar terceiro comprador que oferecesse preço maior do que aquele praticado entre o credor e o devedor.

${ }^{285}$ F.C. PONTES DE MiRANDA. Tratado de direito privado. t. XXI. p. 332-333.

${ }^{286}$ Esse argumento é desenvolvido por J.C. MOREIRA ALVES. Da alienação fiduciária em garantia. $\mathrm{p}$. 133-135. No mesmo sentido, F.C. PONTES DE MIRANDA. Tratado de direito privado. t. III. p. 123: "a aquisição por parte do fiduciário é aquisição como qualquer outra". 
Tudo isso foi dito para justificar o não conhecimento do recurso, o que foi decidido por unanimidade.

\subsubsection{Recurso Extraordinário n. ${ }^{\circ}$ 82.447/SP.}

Esse é, provavelmente, o mais citado acórdão do STF sobre o tema. É também aquele que tem a fundamentação mais longa, e mais detalhada, contida no voto do Min. Moreira Alves. Não é, porém, como visto acima, a decisão pioneira na reversão do entendimento anterior do tribunal sobre a matéria. Os argumentos apresentados no voto do Min. Moreira Alves não vão muito além de tornar mais robustos - com poucas inovações - os mesmos argumentos antes já alinhavados pelo Min. Rodrigues Alckmin no julgamento do Recurso Extraordinário n. ${ }^{\circ}$ 71.616. Esses reforços, no entanto, estão longe de serem desprezíveis. A decisão toca ainda em pontos relevantes para a tese, e que merecem por isso ser destacados.

Os fatos, em síntese, foram os seguintes: Fuad Nasralla, em dezembro de 1965, tomara empréstimo de Félix Salim Daud e, em garantia do débito, transferira a este direitos de promitente comprador de imóvel situado na Capital do Estado de São Paulo, na Avenida Brasil n. ${ }^{\circ}$ 1.286. Quando dessa cessão em garantia, apenas uma parte do preço de aquisição do imóvel havia sido paga aos promitentes vendedores pelo próprio Fuad Nasralla; tratava-se da quantia de Cr\$60.000,00, que consistia no chamado sinal, e que equivalia ao montante do débito contraído perante Félix Salim Daud. Segundo a prova dos autos, o devedor nada pagou ao credor, e este efetivou em favor dos promitentes vendedores todos os demais pagamentos pertinentes à quitação do preço de venda do imóvel em apreço. Durante todo o trâmite da causa, a posse do imóvel permaneceu com o devedor Fuad Nasralla e havia instrumento particular contendo regra pela qual, pago o débito, ficava assegurado ao mesmo Fuad Nasralla o direito de reaver os direitos antes transmitidos em garantia. O credor veio a falecer, o imóvel foi incluído no seu inventário e acabou adjudicado à viúva, Sra. Luiza Daud. O devedor Fuad Nasralla e sua mulher propuseram então ação ordinária visando à declaração de nulidade da escritura 
pública de transmissão dos direitos decorrentes do compromisso de compra e venda de imóvel, por violação ao art. 765 do Código Civil então vigente.

A sentença, em sua fundamentação, pondera com cautela as manifestações doutrinárias de PONTES DE MIRANDA e ALVINO LIMA sobre o assunto. Ao final, inclina-se pela orientação de ALVINO LIMA, no sentido de que incorrem em fraude à lei os negócios pretensamente fiduciários que visam a contornar a proibição do pacto comissório. Em sede de apelação, a sentença foi mantida, por seus próprios fundamentos. O STF, por maioria, conheceu e deu integral provimento ao recurso extraordinário, revertendo por completo as decisões anteriores. Foi vencido o relator, Min. Cordeiro Guerra, para quem "não é lícito ficar o credor com o objeto da garantia se não for pago, e este preceito absoluto se aplica não só aos direitos expressamente mencionados no art. 765 do C.C., como a todos os atos jurídicos que importem garantia do credor".

No voto vencedor do Min. Moreira Alves, cabe sublinhar o seguinte: (a) o negócio celebrado entre as partes qualificava-se como negócio fiduciário, que não se confunde com o negócio simulado e não importa em fraude à lei ${ }^{287}$; (b) havendo negócio fiduciário, é plena a propriedade ou titularidade recebida em garantia pelo credor, de modo que não se aplica à situação a proibição do pacto comissório; tem-se aí direito real (pleno) em garantia, e não direito real de garantia; (c) nenhuma parcela do empréstimo, no caso, fora paga, de modo que não se poderia alegar a incidência de juros superiores aos legalmente admitidos; e (d) a regra do art. 765 do Código Civil então vigente tinha sua incidência restrita aos casos expressamente nela mencionados (penhor, hipoteca e anticrese), não se estendendo a outras hipóteses; deveria prevalecer, nesses termos, a interpretação restritiva da proibição.

Nesse último aspecto, o voto do Min. Moreira Alves foge de uma visão apenas formalista do problema ${ }^{288}$. Ele enfrenta, de modo intrépido, o que esta

${ }^{287}$ Sobre os negócios simulados e fraudulentos, cf. também a decisão, relatada pelo Min. Moreira Alves, havida nos autos do Recurso Extraordinário n. ${ }^{\circ}$ 88.442/RJ. Segunda Turma. j. 13.12.1977. Consultado em www.stf.gov.br; acesso em 11.12.2012.

${ }^{288}$ Ao menos em parte. Em outro trecho do voto, o Min. Moreira Alves, após invocar ensinamento de D. Rubino, assevera: “Temos para nós que, em se tratando do art. 765 do Código Civil, não nos 
tese afirma ser o cerne do problema subjacente à proibição do pacto comissório, nos seguintes termos:

"No penhor e na hipoteca, a diferença de valor entre o débito e a coisa dada em garantia é, em geral, superior a cinquenta por cento do valor da coisa, em decorrência dos percalços da execução e da preferência dos créditos trabalhistas e fiscais, duas dificuldades que foram, aliás, as causas mais importantes da acolhida, no direito moderno, dos negócios jurídicos indiretos em sentido amplo. Isso não ocorre no negócio fiduciário ou no negócio jurídico indireto em sentido estrito, onde não há despesas processuais, demora na execução, aviltamento de preço pela venda em praça, ou possibilidade de diminuição da garantia pela preferência de créditos trabalhistas ou fiscais. No negócio fiduciário, a diferença entre o valor do débito e o da coisa alienada se traduz no montante dos juros, e se estes forem usurários - como saliento mais adiante - haverá fraude à lei da usura, não, porém, ao preceito que veda o pacto comissório".

É de todo correto descortinar os diversos obstáculos que se põem entre o credor e a satisfação efetiva da dívida, no curso da excussão da garantia. Mas é equivocada a atitude de fazer estimativas gerais, a priori, sobre quais seja as dimensões das desproporções entre o valor do bem e o montante da dívida nos casos de penhor e hipoteca, de um lado, e nos casos de transferência fiduciária de propriedade, de outro. Trata-se de uma questão de fato, a ser analisada caso a caso, com recurso a meios idôneos de avaliação do preço de mercado do bem dado em garantia.

encontramos diante de uma daquelas normas às quais Rubino dá a denominação de normas materiais, mas, sim, das que vedam o resultado quando obtido diretamente através de determinada forma jurídica". O argumento faz lembrar, por oposição, a afirnmação de E. BETTI, na linha de que não se cuidaria, na proibição do pacto comissório, de impedir um resultado, mas de coibir um meio, que seria a autotutela ou a satisfação coativa de direitos sem a intermediação do Estado-Juiz. Su gli oneri. p. 705. 
Não se compreende, também, na argumentação do eminente julgador, o porquê de haver fraude a lei em se usar o negócio fiduciário para obter o pagamento de juros usurários ${ }^{289}$ e não haver a mesma fraude em se pretender obstar a vigência da par conditio creditorum e da ordem legal de preferência dos créditos em caso de insolvência do devedor. É acertado, por outro lado, o reconhecimento de que a legalidade dos juros cobrados é uma questão de fato, a ser verificada no caso concreto, inexistindo uma relação necessária e constante entre pacto comissório e usura.

O voto do Min. Moreira Alves constrói ainda outro argumento digno de nota. Ele versa sobre a existência de diferenças estruturais radicais entre a propriedade (plena) transferida pelo negócio fiduciário, e a propriedade fiduciária decorrente, por exemplo, de um contrato de alienação fiduciária em garantia. Citando a si mesmo ${ }^{290}$, o julgador sustenta que a disposição então contida no art. $66, \S 6^{\circ}$, da Lei n. ${ }^{\circ}$ 4.728/65, na redação dada pelo Decreto-lei n. ${ }^{\circ}$ 911/69, representaria uma comprovação de que o art. 765 do Código Civil então vigente não vigorava senão para os casos de hipoteca, penhor e anticrese. Em relação aos artigos 758, 762 e 802 do Código Civil de 1916, era feita remissão expressa pelo art. 66, $§ 7^{\circ}$, da Lei n. ${ }^{\circ}$ 4.728/65, para fins de estender sua incidência ao caso da alienação fiduciária em garantia. Já, todavia, em relação à proibição do pacto comissório, a lei teria optado por reproduzir o texto da proibição (art. $66, \S 6^{\circ}$ ), justamente em virtude da mencionada diferença estrutural entre a propriedade fiduciária e os direitos reais limitados de garantia. Cuida-se, em suma, do mesmo argumento antes utilizado pelo Min. Rodrigues Alckmin, no sentido de que a propriedade transferida pelo negócio fiduciário é propriedade plena, que transforma o adquirente em verdadeiro dominus,

\footnotetext{
${ }^{289}$ Sobre esse ponto, o voto afirma ainda: "Cumpre notar, ainda, que a não aplicação do artigo 765 do Código Civil aos negócios fiduciários não deixa o devedor inerme diante do credor, no nosso sistema jurídico. A diferença entre o valor do direito transferido em garantia e o valor do empréstimo garantido é representada pelos juros do empréstimo, e, se estes forem usurários, a nulidade do negócio se declarará com base, não no pacto comissório (em que a nulidade se restringe à cláusula), mas na violação da Lei de Usura, ou, pelo menos, na fraude a ela. No caso, como salientei anteriormente, inexistem juros usurários". Conforme notado acima, a diferença de valor entre garantia e débito deveria refletir apenas os juros, mas pode refletir muito mais do que eles. Os juros pactuados, realmente, podem não ser suficientes para inteirar toda a discrepância entre o valor de mercado do bem e o montante da dívida. Em outras palavras, nessa discrepância, podem 'caber' não só juros, mas um verdadeiro e próprio excesso, que como regra está presente nas garantias reais de modo geral. De todo modo, o que importa é que isso é uma questão de fato, a ser verificada caso a caso, e que por isso não deve comportar ficções ou presunções.

${ }^{290}$ J.C. MOREIRA ALVES. Da alienação fiduciária em garantia. p. 133-135.
} 
isento de quaisquer das peias inerentes à propriedade fiduciária ou aos direitos reais limitados de garantia, como é o caso da proibição do pacto comissório.

Sobre essas últimas assertivas, cabe perguntar se elas resistem à disciplina geral da propriedade fiduciária, instituída pelos artigos 1.361 a 1.368-A do Código Civil. A resposta correta parece ser negativa. O caput do primeiro desses dispositivos, estatui de modo bastante amplo e geral, que: "Considera-se fiduciária a propriedade resolúvel de coisa móvel infungível que o devedor, com escopo de garantia, transfere ao credor." Para todos os casos abrangidos nessa hipótese, é fora de dúvida que vigora a proibição do pacto comissório (art. 1.365, caput). Na alienação fiduciária de bens imóveis, disciplinada nos artigos 22 a 33 da Lei n. ${ }^{\circ}$ 9.514/97, há norma legal expressa no sentido de que, não purgada a mora do devedor, depois de certo prazo, opera-se a consolidação da propriedade com o fiduciário. A essa consolidação, no entanto, segue-se a imposição da obrigação de levar o bem a leilão público (art. 27). Apenas no caso de não haver, em duas oportunidades, terceiros interessados em adquirir o imóvel por valor superior ao da dívida (caso em que se garante o pagamento do excesso ao devedor), é que pode o credor haver para si em definitivo o bem imóvel. Em contrapartida a essa forma expedita de execução, e excussão, a lei prevê que essa forma de apropriação do bem pelo credor necessariamente extingue a dívida, inexistindo direito do credor a eventual déficit entre o montante da dívida e o valor de mercado do imóvel. $\mathrm{Na}$ alienação fiduciária no mercado financeiro e de capitais, disciplinada pelo art. 66-B da Lei n. ${ }^{\circ} 4.728 / 65$, o respectivo $\S 3^{\circ}$ estabelece que, em caso de inadimplemento, o credor poderá vender a terceiros o bem objeto de garantia. A bem da coerência com as normas do Código Civil, deve-se ler esse "poderá" com o sentido de "deverá". Considerando que essas regras são cogentes ${ }^{291}$, não faz sentido conceber uma forma de propriedade resolúvel, decorrente de negócio fiduciário, e francamente destinada a servir de garantia, mas que possa se postar como imune às regras que visam a controlar o valor pelo qual o bem passa, em definitivo, à propriedade do credor.

\footnotetext{
${ }^{291} \mathrm{O}$ art. 22 da Lei n. ${ }^{\circ}$ 9.514/97 estabelece: "A alienação fiduciária regulada por esta Lei é o negócio jurídico pelo qual o devedor, ou fiduciante, com o escopo de garantia, contrata a transferência ao credor, ou fiduciário, da propriedade resolúvel de coisa imóvel". Praticamente todos os casos analisados pelo STF e tratados neste capítulo envolvem fatos que podem ser reconduzidos à hipótese de incidência desse dispositivo legal. Em todos eles há uma transferência de propriedade sobre bem imóvel que ocorre em caráter acessório à celebração de contrato de mútuo, precisamente para fins de garantia do adimplemento do débito.
} 


\subsubsection{Recurso Extraordinário n. ${ }^{\circ}$ 85.156/PR}

Os fatos que deram origem à demanda são bem resumidos, pela própria decisão, como segue:

"em 10 de junho de 1968, os réus compromissaram ao autor a venda do dito imóvel, e de mais dois lotes, pelo preço total de Cr\$48.000,00, atribuindo-se ao imóvel o preço de $\operatorname{Cr} \$ 38.000,00$, com cláusula de retro-cessão, pelo prazo de um ano. Em 28 de julho de 1969, lavram as partes a escritura de compra e venda do imóvel, porém, antes, no dia 10 de junho de 1969, o autor outorga ao réu uma opção, pelo prazo de um ano, para vender a quem quiser, ou escriturar a si próprio, o aludido imóvel, pelo preço de Cr\$38.000,00; nessa opção, ficou consignado que ao outorgante não caberia qualquer despesa, nem seria devida comissão ao outorgado, o qual, por sua vez, reteria para si qualquer excesso alcançado além do valor acima fixado. Em 16 de dezembro de 1970, o réu concede a Salmir Zaidan Lobato Machado opção para a venda do mesmo imóvel, por Cr\$75.689,00, pelo prazo de noventa dias. Salmir é filho dos réus. Os réus, outrossim, desde a data do compromisso, inclusive, continuaram a ocupar o imóvel. Os autores propuseram a presente ação [reivindicatória] em março de 1972. Durante todo esse tempo não exigiram qualquer retribuição pela ocupação do imóvel, e mesmo nesta ação não formulam pedido de perdas e danos, o que seria lícito que fizessem".

A sentença e o acórdão do Tribunal de Justiça do Paraná entenderam que o arranjo negocial acima descrito resultava em simulação, e infringia a vedação do pacto comissório. No STF, o relator Min. Soares Muñoz votou pelo não conhecimento do recurso, o que tornaria definitiva a aplicação do art. 765 do Código Civil então vigente a hipótese substancialmente idêntica àquelas tratadas nos Recursos Extraordinários n. 71.616 e 82.447. Houve, então, pedido de vista pelo 
Min. Cunha Peixoto. No voto desse último, o negócio jurídico em questão foi qualificado como fiduciário, com consequente afastamento das hipóteses de simulação e fraude. A fundamentação adotada para tanto, apenas reproduziu o quanto firmado nos julgados dos referidos Recursos Extraordinários n. ${ }^{\circ} 71.616$ e 82.447.

\subsubsection{Recurso Extraordinário n. ${ }^{\circ}$ 86.981/PR.}

Esse caso é bastante distinto dos demais. Não houve transmissão, em garantia, nem de propriedade, nem de direitos decorrentes de compromisso de compra e venda de bem imóvel. O que havia era empréstimo garantido por hipoteca, contendo cláusula bastante peculiar, pela qual, em caso de inadimplemento, o credor tinha o direito depositar em favor do devedor a quantia de $\mathrm{Cr} \$ 170.000,00 \mathrm{e}$, com isso, obter a escritura pública de compra e venda do imóvel hipotecado.

O devedor foi à Justiça para obter a declaração de que tal ajuste violaria o art. 765 do Código Civil então vigente. Não teve sucesso. A demanda foi julgada improcedente em primeira e segunda instâncias, e o recurso extraordinário não foi conhecido. Prevaleceu, portanto, a visão de que a referida cláusula não afronta a proibição do pacto comissório.

A solução coaduna-se com o quanto defendido nesta tese, no sentido de que a raiz do problema inerente à proibição do pacto comissório reside no risco de desproporção entre o montante da dívida e o valor de mercado do bem objeto da garantia. No caso, havia consenso prévio entre as partes sobre o montante exato dessa desproporção, e conscientemente se estabeleceu que, mediante o pagamento de valor que a extinguisse, poderia o credor haver para si o bem. O Poder Judiciário entendeu, com razão, que não houve ofensa à lei.

\subsubsection{Recurso Extraordinário n. ${ }^{\circ}$ 90.648/SP.}

Cuidava-se aqui de hipótese relativamente atípica, que não se assemelha à situação mais frequente do negócio fiduciário imobiliário, apreciada na maioria das decisões do STF sobre o tema. 
O Banco Itau de Investimentos S.A. concedera empréstimo ao Cotonifício Demétrio Calfat S.A., tendo como garantia hipoteca de imóvel de propriedade dos acionistas controladores da companhia devedora, Sr. Alfredo Demétrio Calfat e sua esposa. Cuidava-se de imóvel situado na Capital do Estado de São Paulo, na Rua Canário n. ${ }^{\circ} 137$ e terreno contíguo. Sobreveio inadimplemento e foi iniciada ação de execução. No curso do processo de execução, houve cessão do crédito, pelo banco, ao Sr. Gottfried Kurd Riecken. O cessionário então celebrou com os devedores executados "escritura de compra e venda, com dação em pagamento" do imóvel hipotecado. Nesse último negócio, parte do preço foi paga mediante compensação com o crédito exequendo, e parte foi paga em dinheiro. Talvez arrependidos do negócio, os vendedores recusaram-se a transmitir a posse do imóvel ao adquirente, alegando ofensa ao art. 765 do Código Civil então vigente. Diante da recalcitrância, o adquirente aforou ação pelo procedimento ordinário, visando à imissão na posse do imóvel.

O voto do relator, Min. Soares Muñoz, é lacônico. Em essência, aponta que a transferência da propriedade sobre o bem não decorreu de cláusula que pudesse se equiparar a pacto comissório, mas de escritura de dação em pagamento, celebrada após o vencimento, já no curso do processo de execução. São também invocados os precedentes dos Recursos Extraordinários 71.616 e 82.447, como motivos para o não conhecimento do recurso.

Ao julgar desse modo, o tribunal confirmou, em 1979, a licitude das dações em pagamento posteriores ao vencimento. À época, tais dações não contavam com autorização legislativa, o que só viria a ocorrer com a promulgação do Código Civil.

\subsubsection{Recurso Extraordinário n. ${ }^{\circ}$ 98.947/PR.}

Essa foi a última oportunidade em que o tema da proibição do pacto comissório foi julgado pelo STF. No caso, o Sr. Ivan Mário Koch e sua mulher propuseram contra Gastão Fernando Garmatter ação de anulação de negócio jurídico 
de compra e venda, com pacto de retrovenda. Foi relator o Min. Alfredo Buzaid, que assim resumiu a demanda:

“Alegam [os autores] que com o réu Ivan Mário Koch concluíram um contrato de promessa de permuta, obrigando-se os autores a transferir ao referido réu três lotes de terreno, dois em Apucarana e um em Osasco e a receberem em troca dois lotes de terras no município de Londrina, a saber, os de número 135-A e 135-B, com área de 34,38 alqueires. O prazo para o cumprimento das obrigações foi de sessenta dias. Dentro desse prazo transmitiram os autores ao referido réu os imóveis prometidos. O réu, no entanto, deixou de outorgar as escrituras sob a alegação de que, tendo de liquidar dividas, logo mais o faria. Surpreenderam-se os autores com execução movida pelo Banco do Estado do Paraná, na execução $n$. 189/74, em que o lote 135-A foi arrematado pelo credor. Surpreenderam-se também com a notificação que lhes fizera Gastão Fernando Garmatter de que, por escritura pública lavrada nas notas do Tabelião Simoni, adquirira o lote n. 135-B. Entendendo que esta venda encobre um pacto comissório, defeso pelo art. 765 do Código Civil, pretendem a declaração de sua nulidade".

A anulação do negócio, sob o argumento de violação à proibição do pacto comissório, foi deferida pela sentença, e confirmada em sede de apelação. No julgamento do Recurso Extraordinário, tais decisões foram revertidas. O voto do relator apenas reitera os argumentos expendidos nos Recursos Extraordinários 82.447 e 90.648. Conclui que (a) a vedação ao pacto comissório tem lugar, exclusivamente, nos casos de hipoteca, penhor e anticrese; e (b) ela não se estende, portanto, aos casos de transmissão de propriedade plena, operada por negócios fiduciários, que, por sua vez, (c) não se confundem com negócios simulados ou fraudulentos. 


\subsection{As decisões do STJ.}

A análise das decisões do STJ mostrará a ocorrência de um movimento pendular da jurisprudência da instância especial sobre a extensão da proibição do pacto comissório. Opondo-se à diretriz que passou a ser dominante no STF com o julgamento do Recurso Extraordinário n. ${ }^{\circ}$ 71.616, em 1973, o STJ - já em 1991 - retoma o posicionamento que preponderou no STF no período anterior a 1973. O STJ passou a julgar no sentido de que a vedação do pacto comissório é regra aplicável a todos os negócios jurídicos em que há transmissões de titularidade de bens e direitos em garantia, independentemente de qual seja estrutura utilizada para esse fim (hipoteca, penhor, anticrese, alienação fiduciária ou propriedade plena) ${ }^{292}$.

\subsubsection{Recurso Especial n. ${ }^{\circ}$ 2.216/SP ${ }^{293}$}

Os fatos: Rahmo Shayo, Emilia Dwek Shayo, Morris Shayo, Haim Shayo e Rita Shayo, ao que parece, eram sócios ou administradores do Banco Regional S.A.. Por força de dispositivos legais e regulamentares, tais pessoas não podiam tomar empréstimos dessa instituição. Para contornar essa vedação, a referida instituição financeira concedeu mútuo a uma terceira sociedade, denominada Valco Administração, Participações e Representações Ltda., e também a Leivi Abuleac, Fedelis Vaz e Marcos Alvo, os quais posteriormente cederam suas posições no contrato à Citi Engenharia e Comércio S.A.. Esta última tornou-se assim devedora de empréstimo junto ao Banco Regional S.A., mas não recebera os recursos financeiros correspondentes. Por isso, as pessoas físicas inicialmente nominadas (a quem o mútuo efetivamente beneficiara) outorgaram, e logo em seguida receberam de volta, da Citi Engenharia e Comércio S.A., escritura pública de promessa de venda e compra de determinado imóvel. Em outras palavras, a Citi Engenharia e Comércio S.A. figurava formalmente como devedora perante a instituição financeira; passou a

\footnotetext{
292 Além dos acórdãos discutidos a seguir, o tema da proibição do pacto comissório aparece, de soslaio, no Recurso Especial n. ${ }^{\circ}$ 133.541/MG, Quarta Turma, Rel. Min. Sálvio de Figueiredo Teixeira, j. 31.08.1999 consultado em www.stj.gov.br; acesso em 30.10.2009. Aparentemente, o tema teria sido arguido por uma das partes, mas sequer chegou a ser enfrentado na decisão, que se limitou a afirmar que o assunto envolveria análise de fatos e cláusulas contratuais, o que impedia sua apreciação pela instância especial. O mesmo ocorreu no Recurso Especial n. ${ }^{\circ}$ 187.998/SP, Quarta Turma, Rel. Min. Aldir Passarinho Jr., j. 13.12.2005; consultado em www.stj.gov.br; acesso em 11.12.2012.

${ }^{293}$ Terceira Turma, Rel. Min. Nilson Naves, j. 28.05.1991; consultado em www.stj.gov.br; aceso em 30.10.2009.
} 
deter a propriedade de determinado imóvel e compromissou a sua venda com os verdadeiros devedores, isto é, com aqueles a quem o empréstimo gerara benefícios econômicos. Com o recebimento do preço estabelecido no compromisso de venda e compra, a Citi Engenharia e Comércio S.A. poderia então pagar o empréstimo ao banco, o que levaria à transferência da propriedade do imóvel em questão de volta aos devedores.

Todas as partes envolvidas, ao litigarem em juízo, afirmaram que havia no caso simulação, dentre outros fins, destinada a encobrir a celebração de pacto comissório. Diferentes questões jurídicas foram debatidas. Uma delas foi a incidência da vedação do pacto comissório apenas nas hipóteses de hipoteca, penhor e anticrese, ou também em todos e quaisquer negócios que envolvam transmissões em garantia.

O voto do relator, Min. Nilson Naves, assevera que: (a) houve inegável e confessada simulação, destinada a ocultar a realização de mútuo entre o Banco Regional S.A. (que entrou em liquidação extrajudicial e cujos ativos foram posteriormente adquiridos pelo Banco Safra S.A.) e as pessoas físicas indicadas no início do parágrafo anterior; e, principalmente, (b) o preceito que proscreve o pacto comissório "por motivos de ordem ética" deve ser considerado abrangente, e aplicável a todos os contratos que objetivam assegurar ao credor a possibilidade de ficar com bens do devedor em garantia de mútuo, e não apenas à hipoteca, ao penhor e à anticrese. Em apoio a essa argumentação, o voto recorre ao voto vencido do Min. Cordeiro Guerra no Recurso Extraordinário n. ${ }^{\circ} 82.447$ e ao quanto decidido nos autos do Recurso Extraordinário n. ${ }^{\circ}$ 63.128, relatado pelo Min Hermes Lima, para concluir que "em decorrência do negócio simulado, criou-se, aqui, condições para que o credor (sucessor) ficasse com o imóvel, o que evidentemente se acha vedado pela lei".

Sobre incidência ampla da proibição do pacto comissório a todos os contratos destinados a funcionar como garantia, o voto do relator é acompanhado por manifestações do Min. Eduardo Ribeiro e do Min. Dias Trindade. O primeiro afirma, com ênfase, que "Não pode [a proibição do pacto comissório], entretanto, deixar de 
abranger aquelas outras situações em que o não pagamento do empréstimo conduza à perda, em benefício do credor, de um bem, colocado como garantia"; sustenta ainda que o art. 765 do Código Civil então vigente consiste em norma de ordem pública. O segundo - após resumir a igualdade de resultados práticos que alcançam a compra e venda, com pacto de retrovenda, e o pacto comissório - defende que o negócio em questão promove "uma verdadeira usurpação, com evidente enriquecimento sem causa dos autores reconvindos, a recomendar a correção jurisdicional". Por essas razões, o recurso especial foi conhecido e provido.

\subsubsection{Recurso Especial n. ${ }^{\circ}$ 21.681/SP ${ }^{294}$}

Os fatos: foi celebrado entre as partes compromisso de compra e venda de imóvel, que em realidade representava transmissão de direitos em garantia. Caso o débito não fosse pago no vencimento, o bem permaneceria em definitivo com o credor. Ajuizadas demandas de lado a lado, a sentença entendeu que, a despeito de ter havido simulação, nenhuma das partes estava autorizada a invoca-la, nos termos do art. 104 do Código Civil anterior.

Em seu voto, o relator Min. Eduardo Ribeiro basicamente reitera as razões de decidir do Recurso Especial n. 2.216 para: (a) afastar a aplicação do referido art. 104 do Código Civil de 1916; e (b) estender a proibição do pacto comissório a todas as hipóteses de transmissão de direitos em garantia.

\subsubsection{Recurso Especial n. ${ }^{\circ}$ 41.233/SP ${ }^{295}$}

Caso interessante: o Banco Francês e Brasileiro S.A. concedera empréstimo à Safelca S.A. Indústria de Papel e a sociedade a esta coligada. Em garantia desse empréstimo, foi constituída hipoteca. Vencida a obrigação, sem pagamento, as partes entabularam diversas negociações, com auxílio dos respectivos advogados. Renegociada a dívida, a devedora efetuou em favor do credor a dação em pagamento do bem imóvel, antes hipotecado. Ato contínuo, as mesmas partes

\footnotetext{
${ }^{294}$ Terceira Turma, Rel. Min. Eduardo Ribeiro, j. 29.6.1992; consultado em www.stj.gov.br; acesso em 30.10.2009.

${ }^{295}$ Terceira Turma, Rel. Min. Eduardo Ribeiro, j. 22.03.1994; consultado em www.stj.gov.br; acesso em 11.12.2012.
} 
celebraram promessa de venda e compra do mesmo imóvel (o banco como promitente vendedor, e a devedora como promitente compradora), mediante pagamentos parcelados, que evidentemente representavam as parcelas renegociadas para quitação do mútuo. Depois de praticados todos esses atos jurídicos, a devedora foi a juízo para pleitear a anulação das avenças, sob o argumento, dentre outros, de que teriam perpetrado ofensa à proibição do pacto comissório.

O julgado chama a atenção pois vai além de apenas repetir a diretriz de que o art. 765 do Código Civil então vigente não tinha sua incidência restrita às hipóteses de hipoteca, penhor e anticrese. Ele adentra a questão da licitude da dação em pagamento posterior ao vencimento, considerando inclusive os argumentos doutrinários que já eram favoráveis a essa possibilidade, antes da vigência do Código Civil. Nesse particular, o voto do relator, Min. Eduardo Ribeiro, merece ser parcialmente reproduzido:

"Se o devedor, após haver contraído o empréstimo, e sem que se possa vislumbrar que uma coisa condicionara a outra, acerta com o credor que o pagamento da dívida se faria mediante dação, inexiste o vício. A hipótese em exame, entretanto, não é essa. Não ocorreu simplesmente o pagamento, com a transferência da propriedade dos bens. A divida, em verdade, subsistiu, simulando-se a dação e a promessa. Para que a devedora gozasse de um novo prazo, já que não interessava ao banco executar a garantia, engendrou-se aquela fórmula. Em lugar da hipoteca, a transferência de propriedade, que poderia ser readquirida com o pagamento de todo o débito. Não saldasse esse, os bens permaneceriam no domínio do credor com afronta, data vênia, ao citado artigo 765."

Sobre as alegações de que a hipótese não contemplava a cobrança de juros usurários, e de que as partes eram profissionais bem assessorados, ausentes qualquer inexperiência ou coação, o mesmo julgador afirma que: 
“A proibição legal [do pacto comissório] não distingue entre boa e má-fé nem requer demonstração, para incidir, de que tenha havido a debitoris suffocatio, mencionada pelo acórdão como inexistente. Presume-se que o devedor só acede em concluir o negócio, pressionado pelas circunstâncias. E em face do risco de que seja especialmente lesivo, a lei o veda".

Em resumo, o tribunal entendeu que os negócios jurídicos entabulados entre as partes eram nulos por infringirem a vedação ao pacto comissório. Isso foi decidido a despeito de o caso envolver, em realidade, uma dação em pagamento do bem dado em garantia, posterior ao vencimento da dívida.

\subsubsection{Recurso Especial n. ${ }^{\circ}$ 188.318/ES ${ }^{296}$}

O que se passou, nesse caso, foi a dação em pagamento, ao banco credor (Banco Econômico S.A.), de imóveis a ele antes hipotecados. A dação foi celebrada em transação judicial, havida nos autos de execução hipotecária sujeita às disposições da Lei n. ${ }^{\circ}$ 5.741/71. Foi ventilada suposta violação à proibição do pacto comissório, mas ela foi afastada pelo tribunal de origem. Diante dessas circunstâncias, o STJ acabou por não conhecer desse recurso especial. O voto do relator, de todo modo, faz referência expressa ao entendimento dominante no tribunal sobre a ampla incidência da vedação ao pacto comissório em todos os negócios que envolvem transmissões em garantia, independentemente de se tratar de direitos reais de garantia, ou de direitos reais em garantia (Recursos Especiais n. ${ }^{\circ}$ 2.216/SP, 21.681/SP e 41.233/SP).

\subsubsection{Recurso Especial n. ${ }^{\circ}$ 475.040/MG ${ }^{297}$}

Em outubro de 1995, o Sr. Paulo Henrique Gonçalves Pena e sua mulher tomaram empréstimo junto ao Sr. Isidoro Ferreira Batista e sua mulher, no valor de R \$ 150.000,00; na mesma época, os mutuários venderam aos mutuantes, por

296 Terceira Turma, Rel. Min. Carlos Alberto Menezes Direito, j. 27.3.2000; consultado em www.stj.gov.br; acesso em 30.10.2009.

${ }^{297}$ Terceira Turma, Rel. Min. Ari Pargendler. j. 24.06.2003; consultado em www.stj.gov.br; acesso em 30.10.2009. 
esse mesmo valor, determinado imóvel; essa venda foi celebrada com pacto de retrovenda, pela qual os vendedores mutuários poderiam readquirir o bem assim transmitido até maio de 1996. Provas encartadas aos autos demonstravam que, já em outubro de 1995, o valor de mercado do imóvel em questão era de aproximadamente $\mathrm{R}$ \$ 630.000,00; no curso da demanda, em dezembro de 1999, tal valor de mercado alcançou mais de $\mathrm{R} \$ 760.000,00$.

A avença foi declarada nula, em primeira e segunda instâncias, principalmente sob o argumento de que fora malferida a norma proibitiva do pacto comissório. Para manter esse resultado, o STJ decidiu não conhecer o recurso especial. No voto do relator, Min. Ari Pargendler, constam basicamente referências aos precedentes do Recurso Especial n..$^{\circ}$ 2.216, e ganha bastante destaque a enorme desproporção entre o montante da dívida, de um lado ( $\mathrm{R} \$ 150.000,00)$, e o valor de mercado do bem, de outro lado (mais de $\mathrm{R} \$ 760.000,00$ ). Essa desproporção é debitada à conta de juros usurários, mas parece que nem mesmo a mais extorsiva das taxas seria capaz de aumentar o débito nessa magnitude. O mesmo ponto é sublinhado no voto-vista do Min. Carlos Alberto Menezes Direito.

É a primeira ocasião em que o STJ - assumida e expressamente afirma ter revertido o entendimento dominante no STF entre 1973 e 1988, sobre a extensão da proibição do pacto comissório.

\subsubsection{Recurso Especial n. ${ }^{\circ} 158.405 / \mathrm{SP}^{298}$}

A Caixa Econômica Federal concedera empréstimo ao Sr. Carlos Marques Mendes André, e recebera em garantia hipotecária determinado imóvel, situado na Rua Professor Artur Ramos, na capital do Estado de São Paulo. Houve inadimplemento. O banco iniciou então processo de execução, no qual o imóvel hipotecado foi arrestado. Em outra execução, movida por terceiro credor contra o mesmo devedor, o imóvel em apreço foi arrematado pela Caixa Econômica Federal. O devedor insurgiu-se contra a arrematação, alegando que o credor não poderia ficar com o bem objeto da hipoteca, sob pena de violação à regra que proíbe o pacto

${ }^{298}$ Quarta Turma, Rel. Min. Barros Monteiro, j. 21.8.2003; consultado em www.stj.gov.br; acesso em 30.10.2009. 
comissório. O empréstimo fora concedido em 14 de março de 1977. O julgamento do recurso especial ocorreu em 21 de agosto de 2003.

O STJ confirmou o entendimento das instâncias ordinárias no sentido de que a arrematação ou adjudicação do bem objeto de garantia, pelo credor garantido, no curso de execução movida por terceiro (ou pelo próprio credor), não caracteriza a hipótese vedada pelo art. 765 do Código Civil à época vigente. Haveria, para tanto, inclusive, autorização expressa na redação então vigente do art. $690, \S 2^{\circ}$, do Código de Processo Civil.

\subsubsection{Recurso Especial n. ${ }^{\circ}$ 784.273/GO ${ }^{299}$}

Mais um exemplo do caso mais frequente: em garantia de empréstimo contraído por sociedade empresária, os respectivos sócios transferem ao credor a propriedade de bem imóvel, com a previsão de que, saldada a dívida, poderiam os devedores reaver tal propriedade. Nesse caso, havia ainda contrato de locação pelo qual os credores, ou terceiros que lhes fariam as vezes, cediam onerosamente à devedora o uso do bem transmitido em garantia. Findo o prazo para pagamento do débito, ajuizaram ação de despejo, em reação à qual os devedores aforaram ação anulatória da escritura de venda do imóvel.

A sentença e o acórdão proferido em sede de apelação reconheceram ter havido simulação, destinada a acobertar o pacto comissório, vedado pela lei. O tribunal manteve essa solução, ao não conhecer do recurso especial. Como fundamento da decisão, invocou basicamente o precedente do Recurso Especial n. ${ }^{\circ}$ 21.681 .

\subsubsection{Recurso Especial n. ${ }^{\circ}$ 274.588/PR ${ }^{300}$}

Em resumo, o Banco do Brasil S.A. concedera empréstimo à Lapsen S.A., na modalidade de Adiantamento sobre Contrato de Câmbio ("ACC"). Em

299 Terceira Turma, Rel. Min. Carlos Alberto Menezes Direito, j. 12.12.2006; consultado em www.stj.gov.br; acesso em 30.10.2009.

${ }^{300}$ Quarta Turma, Rel. Min. Luis Felipe Salomão, j. 19.3.2009; consultado em www.stj.gov.br; acesso em 30.10.2009. 
garantia do pontual adimplemento do débito, a devedora efetuou depósito de recursos junto à mesma instituição financeira, por força do qual foram emitidos Recibos de Depósito Bancário ("RDB”). A devedora, ao que consta dos autos, entrou em concordata preventiva e, posteriormente, veio a falir. Valendo-se de autorização expressa e específica contida nos documentos contratuais, o banco - quando do vencimento - liquidou a aplicação financeira representada pelo referido RDB e aplicou os recursos financeiros daí decorrentes no pagamento da dívida decorrente do ACC. Os fatos, ao que se relata, ocorreram durante a concordata preventiva, antes, portanto, de a devedora falir. No curso da falência, foi posta em xeque a atitude do banco, sob o argumento de que teria consistido em ofensa ao art. 765 do Código Civil então vigente.

O relator, Min. Luis Felipe Salomão, entendeu que a questão primordial a ser definida era justamente a legalidade de "se usar a garantia fornecida mediante 'RDB's' a contrato de câmbio para amortizar ou liquidar a dívida”. No caso, restou incontroverso que se tratava de "garantia em dinheiro" e que existia cláusula contratual que autorizava o banco a proceder como de fato procedeu. Diante desses fatos, o tribunal - em passagem que merece transcrição - assim julgou:

"A aplicação dos valores oferecidos em garantia para amortização da dívida é rigorosamente o mesmo que dela se apropriar, revelando a cláusula contratual em questão verdadeiro pacto comissório, vedado pelo ordenamento jurídico. (....)

Conclusão diversa consubstanciaria autorização judicial a burla ao ordenamento, de sorte que não mais haveria execução de débitos garantidos por penhor, por exemplo, haja vista a possibilidade de o credor lançar mão de instrumento contratual que lhe assegure a 'amortização' da dívida utilizando-se da garantia pignoratícia.

A vedação, em realidade, não é destituída de causa. A ultima ratio desta proibição reside no escopo de se preservar a igualdade dos contraentes, partindo-se da premissa de que o devedor é a parte mais 
frágil do contrato. Por outro lado, a proibição de pacto comissório visa a afastar a possibilidade de apropriação de bens que, por vezes, superam em muito o valor da divida."

A corte chega ainda a afirmar que a conduta do credor teria implicado uso arbitrário das próprias razões. O contrato de empréstimo fora celebrado em 6 de agosto de 1990. O recurso especial foi julgado quase 19 anos depois, em 19 de março de 2009.

Esse acórdão é especialmente interessante para os fins desta tese. Por um lado, ele parece veicular o argumento de BETTI sobre os motivos da proibição do pacto comissório, que se rechaçou no item 4.3. Ele exprime, ademais, certa repulsa por meios extrajudiciais de execução de bens empenhados, no que parece não dar o devido peso às inúmeras hipóteses em que a legislação autoriza essa forma de excussão, todas elas também tratadas no referido item 4.3. Por outro lado, a decisão não deixa também de reconhecer entre esses mesmo motivos o risco de desproporção entre a dívida e o valor do bem dado em garantia. É o único entre os acórdãos estudados que analisa o pacto comissório no contexto da falência, embora não chegue a enfrentar as relações entre a cláusula e a preservação da par conditio creditorum. A decisão deixa ainda de considerar como decisivo o fato de a garantia já ser representada por aplicação financeira, o que torna imediatamente perceptível a eventual desproporção entre o valor da garantia e o montante da dívida. Sendo identificada de imediato a desproporção, esse confronto entre valores já nominados em dinheiro por si só determina, conforme o caso, a obrigação do credor de restituir o excesso, ou a permanência da responsabilidade do devedor pelo déficit, conforme visto no capítulo 4.

\subsubsection{Recurso Especial n. ${ }^{\circ}$ 998.460/SP ${ }^{301}$}

Segundo a pesquisa realizada, esse é o mais recente acórdão do STJ dentre os já publicados ${ }^{302}$ - em que é enfrentado com franqueza o tema da tese. Ele

${ }^{301}$ Terceira Turma, Rel. Min. Nancy Andrigui, j. 22.2.2010; consultado em www.stj.gov.br, acesso em 16.12.2012. 
data de 23 de fevereiro de 2010. Figurou como recorrente o Sr. Pierre Loeb e como recorrida Brinter Importadora e Exportadora Ltda. e seu sócio Sr. Joel Shigueru Yamanaca. O recorrente teria emprestado $\mathrm{R} \$ 100.000,00$ à recorrida Brinter Importadora e Exportadora Ltda. e, segundo se alega, o segundo recorrido teria efetuado, em garantia, a transmissão ao credor da propriedade do imóvel em que se situava a sede da sociedade. Para autorizar a continuidade da transmitente na posse, foi celebrado contrato de comodato. Vencida a dívida, sem adimplemento, o credor ajuizou ação de reintegração na posse do imóvel. Em contraposição a essa demanda, os recorridos no recurso especial (devedores no empréstimo) ajuizaram ação de anulação de ato jurídico, sob o argumento de que teria sido violada a proibição do pacto comissório.

A decisão em nada inova em relação à jurisprudência que se consolidou no STJ a partir do julgamento do Recurso Especial n. ${ }^{\circ}$ 2.216. Somente reitera, portanto, que a proibição do pacto comissório é aplicável a todas as transmissões em garantia, independentemente de se tratar de direitos reais de garantia (penhor, hipoteca, anticrese e alienação fiduciária) ou de direitos reais $\mathrm{em}$ garantia (transmissão de propriedade plena, com função de garantia).

\subsection{A trajetória das decisões sobre a proibição do pacto comissório.}

A orientação dominante, nas cortes brasileiras, sobre o âmbito de incidência da proibição do pacto comissório passou por interessantes transformações.

\footnotetext{
${ }^{302}$ Nos estertores do prazo para conclusão da tese, foi divulgado o resultado do julgamento nos autos do Recurso Especial n. ${ }^{\circ}$ 954.903/RS, Quarta Turma, Rel. Min. Marco Buzzi, j. 11.12.2012. A notícia $\begin{array}{lllllll}\text { foi dada no próprio sítio do } & \text { STJ, em } & \text { 28.12.2012 }\end{array}$ (http://www.stj.gov.br/portal_stj/publicacao/engine.wsp?tmp.area=398\&tmp.texto=108199; acesso em 02.01.2013). A publicação do acórdão está prevista para 01.02.2013. Segundo essa notícia, o voto do relator teria sustentado que: "A figura do pacto comissório traduz-se na proibição de celebração de negócio jurídico que autorize o credor a apropriar-se da coisa dada em garantia, em caso de inadimplência do devedor, sem antes proceder à execução judicial do débito garantido" (...) "A pactuação realizada, de forma dissimulada, com o aludido mister é nula de pleno direito, caracterizando norma de ordem pública, cognoscível de ofício pelo magistrado, por revelar manifesta fraude ao ordenamento jurídico" (...) "No caso concreto, os promissários compradores executaram promessas de compra e venda de terrenos urbanos que, firmadas sob a égide do Código Civil de 1916, tinha, incontroversamente, a finalidade de garantir o adimplemento de contrato de faturização". Tal como no caso do Recurso Especial n. ${ }^{\circ} 274.588 / \mathrm{PR}$, parece haver a adoção do argumento de BETTI sobre o caráter inderrogável da execução judicial como forma de excussão da garantia.
} 
Durante as décadas de 1970 e 1980, o STF firmou o entendimento, consolidado em um número razoável de acórdãos, de que a vedação ao pacto comissório tinha sua incidência restrita às garantias reais típicas: penhor, hipoteca e anticrese. De acordo com esse entendimento, nada impedia que o pacto comissório fosse avençado em negócios fiduciários de modo geral, que não se confundissem com as referidas garantias reais típicas. Foram duas, em síntese, as razões que deram corpo a essa orientação. A primeira, mais genérica, era a de que, em se tratando de norma proibitiva, não poderia haver interpretação extensiva ou mesmo analógica. Assim, se a proibição era explicitamente dirigida àqueles que contratavam penhor, hipoteca ou anticrese, não poderia ser imposta às relações em que os particulares, conscientemente, optaram pela celebração de outros negócios jurídicos, distintos dos mencionados na norma restritiva. A segunda razão, mais específica, residia na diferença de estrutura entre os negócios fiduciários, de um lado, e os negócios de constituição de direitos reais de garantia, de outro.

Sem para tanto invocar o art. 1.365 do Código Civil, o STJ adotou sobre o tema posição oposta àquela sedimentada pelo STF entre 1973 e 1988. Essa modificação foi consciente, como se extrai da ementa do acórdão proferido nos autos do Recurso Especial n. ${ }^{\circ}$ 475.040:

“A jurisprudência do Superior Tribunal de Justiça se consolidou no sentido de que o pacto comissório não se limita aos casos expressamente previstos no art. 765 do Código Civil, diversamente da posição do Supremo Tribunal Federal, o qual entendia que a norma nele contida tinha abrangência restrita".

Essa mudança na orientação dominante teve origem no aresto proferido nos autos do Recurso Especial n. ${ }^{\circ}$ 2.216. Desde então, um número representativo de acórdãos do STJ tratou, ou ao menos tangenciou o assunto, conforme o caso, sempre em oposição à linha estabelecida pelo STF a partir de 1973. As fundamentações desses julgados não se esmeram em explicar o porquê de a orientação anterior merecer reforma. Nenhuma delas usa como motivo eventuais modificações legislativas decorrentes da entrada em vigor do Código Civil. 
Apesar disso, é possível identificar, na postura assumida pelo STJ, a percepção de que o negócio fiduciário que atinge o mesmo efeito do pacto comissório implica fraude à lei, particularmente, mas não apenas, nas hipóteses em que se verifica a cobrança de juros superiores aos permitidos. Sendo vedado atingir o resultado da transferência da propriedade em pagamento nos casos de penhor, hipoteca e anticrese, o STJ tem entendido que a proibição não pode ser contornada pelo mero recurso à figura dos negócios fiduciários, que são assim equiparados a negócios simulados, e não a negócios indiretos lícitos.

Longe de ser propriamente nova, a orientação hoje dominante no STJ, em verdade, retoma a visão que prevalecia no STF até cerca de 1973. Houve, portanto, uma oscilação pendular no comportamento da jurisprudência da instância especial, segundo o qual: (a) até 1973, prevaleceu no STF uma abordagem que se pode chamar de funcional, em que finalidade da transmissão de propriedade sobrepuja a estrutura da propriedade plena que é transferida ao credor no negócio fiduciário; (b) entre 1973 e 1991, aproximadamente, a tônica das decisões do STF desloca-se para uma leitura por assim dizer estrutural do problema; tratando-se de propriedade plena, ainda que transmitida para fins de garantia, não se poderia impedir o credor de se tornar o que ele já é; e por fim (c) de 1991 em diante, o STJ volta a adotar o entendimento que aqui se adjetiva de funcional, pois trata sob a mesma disciplina, em relação ao pacto comissório, todas as diferentes estruturas jurídicas que possam servir ao propósito de garantia do adimplemento de obrigações.

Em relação às duas questões que serviram de pontos de partida da investigação: (a) não há um entendimento uníssono, na jurisprudência dos tribunais superiores brasileiros, sobre qual seja o fundamento da proibição do pacto comissório; diversos julgados, em diferentes contextos, apoiaram-se em menor ou maior extensão em praticamente todas as justificativas testadas no capítulo 4 (proteção do devedor, repressão à usura, caráter inderrogável da via judicial como forma de execução, interesse social em coibir a difusão do pacto comissório e, em menor intensidade, preservação da par conditio creditorum); mas (b) apesar dessa inconstância quanto à identificação dos fundamentos da proibição, predomina hoje, 
no STJ, a posição de que a interdição do pacto comissório não está restrita aos direitos reais de garantia; ela é aplicável sempre que houver transmissão de direitos a título de garantia, inclusive nos casos de negócios fiduciários. 


\section{O QUE MAIS ESTÁ EM JOGO NA PROIBIÇÃO DO PACTO COMISSÓRIO.}

\subsection{Pacto comissório e política econômica.}

No período compreendido entre os anos de 1950 e 1980, o Brasil experimentou expressivo crescimento econômico; a isso seguiram pouco mais de duas décadas de estagnação ${ }^{303}$. Diversos fatores são considerados, pela literatura especializada, como causas do esgotamento do dinamismo verificado nas décadas do milagre econômico. Igualmente distintos são os possíveis caminhos apontados para a retomada do crescimento em bases constantes e sustentáveis. Um deles corresponde à existência de mecanismos jurídicos e institucionais adequados ao bom funcionamento dos mercados e à eficiência das políticas públicas ${ }^{304}$.

Há dois assuntos recorrentes, nesse debate, que são tidos como especialmente importantes para o desenvolvimento da economia brasileira. Esses dois tópicos guardam relação próxima com o feixe de temas ligados à proibição do pacto comissório. Tais temas estão inseridos no contexto das chamadas reformas microeconômicas ou institucionais, e correspondem: (a) a um maior desenvolvimento do mercado de crédito; e (b) à redução do custo de resolução dos conflitos $^{305}$. Para robustecer o mercado de crédito, as reformas microeconômicas buscam, basicamente, "desenvolver novos instrumentos para o financiamento privado e (...) criar condições para a queda das taxas de juros de mercado". No mesmo sentido, o aludido estudo do Ministério da Fazenda sustenta que: "Maiores

\footnotetext{
${ }^{303}$ Sobre esse assunto e o argumento geral deste item 6.1, cf. Ministério da Fazenda. Secretaria de Política Econômica. Reformas microeconômicas e crescimento de longo prazo. Brasília, 2004, texto consultado em http://www.fazenda.gov.br/spe/publicacoes/reformasinstitucionais/estudos/Texto_VersaoFinal5.pdf; acesso em 8.7.2011, de ora em diante citado como Reformas microeconômicas; e a obra de E.R. FABIANI. Direito e crédito bancário no Brasil. São Paulo, Saraiva/FGV, 2011. Contendo apanhado da literatura internacional sobre o assunto, cf. K.W. DAM. Credit markets, creditor's rights and economic development. John M. Olin Law and Economics Working Paper n. 281 (2D Series). The Law School. The University of Chicago. Consultado em http://ssrn.com/abstract id=885198; acesso em 28.12.2012. Merece menção ainda o relatório do Banco Mundial intitulado The World Bank principles and guidelines for effective insolvency and creditor rights systems. Washington D.C. - The Worldbank. http://documents.worldbank.org/curated/en/2001/04/10465125/world-bank-principlesguidelines-effective-insolvency-creditor-rights-systems; acesso em 28.12.2012.

${ }^{304}$ Reformas microeconômicas. p. 6.

305 Além desses dois, são também mencionados: a melhoria da qualidade da tributação, medidas econômicas para inclusão social e a melhoria do ambiente de negócios.
} 
custos na resolução de conflitos levam a aumento nos preços pagos pelos consumidores e nas taxas de juros dos empréstimos, além de, em muitos casos, excluir as famílias que não têm acesso a garantias do mercado de crédito".

Integram o arcabouço legislativo concebido para implementar as mencionadas reformas microeconômicas: (a) a disciplina do chamado crédito consignado, regido pela Lei n. $^{\circ}$ 10.820/03; (a) a criação da Cédula de Crédito Bancário, do patrimônio de afetação e as demais medidas de fomento ao crédito imobiliário, todas previstas na Lei n. ${ }^{\circ} 10.931 / 04$; (c) a aprovação da Lei de Falências, que instituiu a figura da recuperação judicial e extrajudicial, em substituição ao antigo instituto da concordata, e subordinou, na falência, os direitos do fisco aos direitos dos titulares de garantias reais, dentre outros credores; (d) a criação de novos títulos de crédito destinados ao fomento do agronegócio, como o Certificado de Depósito Agropecuário e o Warrant Agropecuário (Lei n. ${ }^{\circ}$ 11.076/04); (e) a criação do sistema de pagamentos brasileiro (Lei n. ${ }^{\circ} 10.214 / 01$ ); e (f) a ampliação da figura da alienação fiduciária em garantia, tanto no âmbito do mercado financeiro e de capitais (Lei n. ${ }^{\circ}$ 4.728/65), como meio de estímulo ao financiamento imobiliário (citada Lei n. $\left.{ }^{\circ} 10.931 / 04\right)^{306}$. Esse conjunto, relativamente ordenado, de modificações legislativas tem por norte a ideia de que:

\begin{abstract}
"um dos fatores mais evidentes que justificam o baixo volume e o elevado custo do crédito são os longos e onerosos processos de execução das garantias e ressarcimento de dívidas, prevalecendo, inclusive, a incerteza se após esses processos as dívidas serão ou não pagas.".
\end{abstract}

Diagnóstico semelhante pode ser encontrado em outro estudo, elaborado por economistas do Banco Central do Brasil, intitulado Sistema judicial e mercado de crédito do Brasil ${ }^{307}$. Esse artigo defende que os custos e o tempo

\footnotetext{
${ }^{306}$ Para uma visão de conjunto sobre essas modificações legislativas, cf. E.R. FABIANI. Direito $e$ crédito bancário no Brasil.

${ }^{307}$ Notas técnicas do Banco Central do Brasil. n. ${ }^{\circ}$ 35. Maio de 2003. Sistema judicial e mercado de crédito no Brasil (Pedro Fachada, Luiz Fernando Figueiredo e Eduardo Lundberg). Consultado em http://www.bcb.gov.br/pec/notastecnicas/port/2003nt35sistemajudicialmercadocredbrasilp.pdf; acesso em 9.7.2011. Assim como o texto Reformas microeconômica, esse texto também é analisado em profundidade por E.R. FABIANI. Direito e crédito bancário no Brasil.
} 
associados à execução forçada das obrigações assumidas em empréstimos constituem uma das principais causas das altas taxas de juros praticadas no país, e representaria um desestímulo à expansão do crédito destinado ao financiamento de atividades produtivas. O conjunto da sociedade acabaria por suportar o aumento do prêmio de risco embutido no chamado spread bancário e a diminuição dos recursos disponíveis ao crédito privado ${ }^{308}$.

A revisão dos fundamentos da proibição do pacto comissório e as sugestões de modificação do direito vigente, apresentadas no capítulo 4, podem contribuir para esse aperfeiçoamento dos institutos jurídicos que servem o mercado de crédito. A tese demonstrou que a vedação ao pacto comissório visa a evitar um resultado reprovável, que é o enriquecimento do credor de modo desproporcional ao valor do seu crédito, com prejuízos para o devedor e, possivelmente, aos demais credores do devedor. Foi refutada a concepção de que o quid censurável no pacto comissório seria o meio empregado (isto é, a autossatisfação do credor, sem trâmite judicial). Ao se restringir o cerne da proibição ao controle da adequação entre o valor de mercado do bem objeto da garantia, de um lado, e o valor da dívida, de outro, abre-se caminho para a construção de mecanismos extrajudiciais pelos quais essa aferição pode ser feita.

Com frequência, os bens dados em garantia têm valor de mercado divulgado por índices confiáveis, como é o caso de veículos automotores, por exemplo, ou são negociados em bolsa de valores, como ocorre com produtos agrícolas e commodities em geral. Nessas situações, parece desnecessário exigir que o credor precise se valer de processo judicial para excutir o bem já destinado pelo próprio devedor como apto à satisfação da dívida, quando da constituição da garantia. Se há índices públicos confiáveis, que permitem determinar com segurança o valor de mercado do bem dado em garantia, não há porque se estabelecer procedimento de excussão distinto daquele já admitido pelo próprio Código Civil para os casos de penhor de créditos e títulos de crédito, ou discrepante do que seria

\footnotetext{
${ }^{308}$ Sobre as correlações entre o dinamismo do mercado de crédito e as características dos institutos jurídicos que o amparam, cf. R. HASElmann, K. PISTOR e V.Vig. How Law Affects Lending. Consultado em http://ssrn.com/abstract=846665; acesso em 9.7.2011 e JOHN ARMOUR. The law and economics debate about secured lending: lessons for european lawmaking? Consultado em http://ssrn.com/abstract=1118030; acesso em 9.7.2011.
} 
decorrente da celebração de um pacto marciano. Se o bem tiver valor de mercado superior ao montante da dívida, e o devedor for solvente, não parece haver prejuízo em o credor se tornar proprietário dele mediante a exigência concomitante de entrega do excesso ao devedor. Nada diferente, em substância, do que já se passa: (i) no caso do pacto marciano e (ii) na própria determinação do preço no contrato de compra e venda, que pode ser cometida a terceiro (art. 485 do Código Civil), fixada por referência a taxas de mercado ou bolsa (art. 486) ou ainda definida "em função de indices ou parâmetros, desde que suscetíveis de objetiva determinação" (art. 487).

Está em curso no país um candente debate entre o governo federal, de um lado, e as instituições financeiras privadas, de outro, sobre a diminuição das taxas de juros. Dado o recente movimento de queda das taxas de juros pagas pelo próprio governo no financiamento de sua dívida, as autoridades federais têm cobrado as instituições financeiras privadas, com alguma insistência, para que também reduzam os juros por elas praticados ${ }^{309}$. As instituições financeiras privadas, em resposta a essa pressão, argumentam que um dos principais fatores que estariam a impedir a queda mais acentuada das taxas de juros por elas praticadas seria justamente a dificuldade de executar os créditos e excutir garantias em caso de inadimplemento ${ }^{310}$; buscam também despolitizar o debate, o que parece ser uma tentativa de evitar um confronto aberto com o discurso adotado pelo governo ${ }^{311}$.

\footnotetext{
${ }^{309}$ Cf., por exemplo, a matéria "Nova cobrança do governo por queda dos juros incomoda o setor financeiro. Em jantar da Febraban, ministra Gleisi Hoffman diz que País só será desenvolvido e equilibrado se processo de redução das taxas continuar", publicada no Estado de São Paulo, edição de 15 de dezembro de 2012, p. B-1. A matéria destaca trecho do discurso da ministra, segundo o qual: "Baratear o crédito é garantir investimentos, gerar processo e desenvolvimento. É apostar num círculo virtuoso da vida e das relações. Este é o nosso chamado".

310 Cf. a matéria "Bancos vão pedir mais garantias nos empréstimos para reduzir o spread. Bancos apresentarão hoje ao Ministério da Fazenda uma lista com mais de 20 sugestões para tentar diminuir as margens cobradas nos empréstimos, o chamado spread. Na lista, o tema dominante é a segurança jurídica dos financiamentos. O setor financeiro argumenta que, quanto mais segura for a execução de dívidas atrasadas, menor será o juro cobrado dos clientes." Estado de São Paulo, edição de 10 de abril de 2012, p. B-1.

311 Cf. a entrevista do presidente da Federação Brasileira de Bancos - Febraban, Murilo Portugal, publicada no Estado de São Paulo, edição de 18 de março de 2012, p. B-11. Nela o entrevistado afirma que "Redução dos spreads não deve ser agenda política" e, sobre os componentes precificados nas taxa de juros, defende que "Por exemplo, no Brasil há uma taxa muito baixa de recuperação dos créditos que ficam inadimplentes. A taxa de inadimplência em si não é tão alta, comparada internacionalmente, mas a taxa de recuperação é baixa em razão de problemas no nosso sistema judiciário".
} 
Esta tese não pretende fazer julgamentos sobre a procedência dos argumentos que, nessa contenda, são sustentados de lado a lado. Ela oferece, porém, uma contribuição modesta, mas que se acredita possa ser útil para o desenlace dessa discussão. Demonstrou-se, realmente, que o direito brasileiro comportaria - sem prejuízos aos direitos dos devedores - novos mecanismos extrajudiciais de excussão de garantias, que se apoiassem na licitude do pacto marciano e na sistemática já presente nos casos em que a garantia se encontra nominada em dinheiro. É impossível prever se as alterações legislativas sugeridas no capítulo 4 teriam o efeito de contribuir para a diminuição das taxas de juros cobradas no país. Mas já haverá ganho se for possível, pelo menos, excluir do debate as reclamações recorrentes sobre falta de segurança jurídica e lentidão judicial. Com essa exclusão, a discussão poderia se concentrar em outros aspectos, como tributos, depósitos compulsórios, concorrência e margens de lucro ${ }^{312}$.

Nota-se, por fim, que o interesse presumido das instituições financeiras volta-se à excussão da garantia, com o objetivo de com ela fazer dinheiro. Entre aqueles que não têm acesso ao mercado organizado de crédito, é frequente que o credor tenha interesse em realmente se apropriar em definitivo da coisa dada em garantia, como ilustram boa parte dos julgados discutidos no capítulo 5. Para as instituições financeiras, de modo geral, é evidente a preferência e a necessidade de liquidez, e a conveniência de evitar os custos incorridos com a apropriação e posterior alienação do bem dado em garantia.

\subsection{Tendências internacionais na disciplina das garantias ${ }^{313}$.}

Podem ser hoje identificadas, em diferentes países, (i) diversas iniciativas de atualização e reforma legislativa em matéria de garantias de

\footnotetext{
${ }^{312}$ Esses outros aspectos são mencionados na entrevista citada na nota imediatamente anterior.

${ }^{313} \mathrm{O}$ quanto consta desta seção foi extraído basicamente de H. SIGMAN. Security in movables in the United States - Uniform Commercial Code Article 9: a basis for comparison. In: Security Rights in Movable Property in European Private Law. Edited by Eva-Maria Kieninger. Cambridge: Cambridge University Press. 2009. p. 54-80. E. WARREN. Bankruptcy and Article 9. Statutory supplement. Austin, Wolters Kluwer, 2010. Também a respeito das tendências internacionais verificadas na disciplina da matéria, cf. C. DE CORES e E. GABRIELLI. El nuevo derecho de las garantias reales. Estudio comparado de las recientes tendencias en materia de garantias reales mobiliarias. Bogotá, Temis, 2008.
} 
empréstimos; e (ii) uma pluralidade de projetos de uniformização ou harmonização legislativa nesse mesmo assunto.

Nesse contexto, o Article 9 do UCC é seguramente a experiência mais influente no mundo sobre o tema da disciplina e excussão de garantias contratuais. $\mathrm{O}$ mercado de crédito norte-americano é amplamente apoiado na constituição de garantias $^{314}$. O texto do Article 9 do UCC foi adotado como base para a regulamentação da matéria na maior parte das províncias canadenses, além de ter servido de guia para a elaboração de leis-modelo e tratados internacionais no âmbito: (a) do Banco Europeu para a Reconstrução e o Desenvolvimento (EBRD) ${ }^{315}$, (b) das Nações Unidas - UNCITRAL e do Instituto Internacional para a Unificação do Direito Privado - UNIDROIT ${ }^{316}$ e (c) da Organização dos Estados Americanos ${ }^{317}$. Há ainda notícias de o diploma ter inspirado reformas legislativas na Nova Zelândia, na Europa Oriental e no México. Essa intensa, generalizada, e por vezes irrefletida, importação do modelo norte-americano é criticada por MCCORMACK, para quem o sistema do Article 9 do UCC forma uma unidade com o direito falimentar norteamericano, que não pode ser desconsiderada, e geralmente $e^{318}$.

É conveniente, portanto, que uma eventual iniciativa de levar à frente as modificações legislativas descritas no capítulo 4 leve em conta o conteúdo dos projetos e modelos citados no parágrafo anterior.

\footnotetext{
${ }^{314}$ R. J. MANN. Explaining the pattern of secured credit. Harvard Law Review. v. 110. n. 625. p. 625683. 1997.

${ }^{315}$ European Bank for Reconstruction and Development - ERDB. Model law on secured transactions. Consultado em http://www.ebrd.com/downloads/legal/secured/modellaw.pdf; acesso em 28.12.2012.

${ }^{316}$ United Nations Comission on International Trade Law. Legislative guide on secured transactions. Consultado em http://www.uncitral.org/pdf/english/texts/security-lg/e/09-82670_Ebook-Guide_0904-10English.pdf; acesso em 28.12.2012.

317 Organization of the American States. Model Inter American Law on Secured Transactions. Consultado em http://www.oas.org/dil/Model_Law_on_Secured_Transactions.pdf; acesso em 28.12.2012.

318 G. MCCORMACK. Secured credit and the harmonization of law. The UNCITRAL experience. Cheltenham/Northhampton, Edward Elgar, 2011. p. 101.
} 


\subsection{Profetas, mercadores, agiotas, juristas e atormentados em geral.}

A proibição do pacto comissório deita raízes em uma situação de conflito tão antiga quanto constante nas comunidades humanas. Ela é criada pelo poder daqueles que, estando em posição econômica e social mais confortável, emprestam recursos, profissionalmente ou não, àqueles que estão em posição mais frágil e, para obter o empréstimo, são compelidos a dar em garantia bens que lhe são caros. O inadimplemento e a iminência da excussão da garantia inflamam esse embate.

No antigo testamento, mais precisamente no livro do profeta Neemias (5, 1-13) - que data de cerca de 300 a.c. - há uma demonstração eloquente das queixas que o povo hebreu fazia a esse respeito:

"Uns diziam: 'Somos obrigados a penhorar nossos filhos e nossas filhas para recebermos trigo, para podermos comer e sobreviver'. Outros diziam: 'Temos que empenhar nossos campos, vinhas e casas para recebermos trigo durante a penúria'. Outros ainda diziam: 'Tivemos que tomar dinheiro emprestado penhorando nossos campos e vinhas para pagarmos o tributo do rei; ora, temos a mesma carne que nossos irmãos e nossos filhos são como os deles: no entanto, temos que entregar à escravidão nossos filhos e filhas, e há entre nossas filhas algumas que já são escravas! Não podemos fazer nada, porque nossos campos e nossas vinhas já pertencem a outros"319.

Na tradição ocidental, o texto talvez mais expressivo desse conflito é a comédia The Comical History of the Merchant of Venice, de SHAKESPEARE ${ }^{320}$. O mote da peça é precisamente a celebração, e a tentativa de excussão, de penhor de

319 Bíblia de Jerusalém. São Paulo, Paulus, 2002. A edição contém interessante introdução, com contextualização histórica, aos livros de Esdras e Neemias, que formam conjunto com o Livro das Crônicas.

${ }^{320}$ The Oxford Shakespeare. The complete works. (General editors Stanley Wells and Gary Taylor). Edited by John Jowett, William Montgomery, Gary Taylor and Stanley Wells. Oxford, Claredon Press, 2005. p.454-479. 
certa quantidade de carne (a pound of flesh) do corpo do devedor, o mercador Antonio, que havia sido dada em garantia de empréstimo tomado junto a Shylock ${ }^{321}$.

Antonio imaginava que poderia pagar o empréstimo com certa facilidade, com uso de receitas que lhe seriam proporcionadas pelo retorno de navios mercantes seus que estavam em viagem. As embarcações deveriam retornar cerca de um mês antes do vencimento da obrigação. No entanto, os navios sofrem revezes, não retornam a Veneza e o devedor fica sem recursos para cumprir a obrigação. Sobrevém o vencimento, sem adimplemento, e o credor Shylock busca então o cumprimento forçado da promessa de entrega de certa quantidade de carne do corpo do devedor, a ser retirada, segundo sua escolha, de local próximo ao coração de Antonio. A despeito de receber dos amigos do devedor diversas ofertas de pagamento, algumas de valores superiores à dívida, Shylock faz questão de receber de Antonio o exato bem dado em garantia, conforme previsto no título em que fora constituído o penhor.

A herdeira Portia, trasvestida de jurista e julgadora oriunda da escola de direito de Padova, vê-se então perante um dilema: manter a integridade das leis de Veneza, que reclamavam o respeito à letra do contrato e a excussão rigorosa da garantia ou reconhecer a iniquidade dessa mesma excussão? A julgadora sai-se com o conhecido estratagema de, por um lado, reconhecer a validade da garantia e o direito do credor de obter a quantidade avençada de carne do corpo de Antonio. Mas sustenta, por outro lado, que a mesma letra do contrato não dava ao credor nenhum

\footnotetext{
${ }^{321}$ É extremamente arriscado pinçar trechos de uma peça de Shakespeare. Mas não se resiste a apontar uma passagem, pela forma como ela se comunica com a discussão aqui empreendida sobre a proibição do pacto comissório. No primeiro ato, cena 3, é especialmente interessante a ponderação feita por Antonio a Shylock, como induzimento à concessão do empréstimo, no sentido de que seria melhor emprestar aos inimigos do que aos amigos, pois em caso de descumprimento não haverá o constrangimento - e talvez haja até prazer - em exigir coativamente a obrigação:

"if thou wilt lend this money, lend it not

As to thy friends; for when did friendship take

A breed of barren metal of this friend?

But lend it rather to thine enemy,

Who if he break, thou mayst with better face

Exact the penalty" (p. 458).
}

Não deixa de ser uma confirmação do argumento aqui defendido, na linha de que a fragilidade do devedor, por ocasião do vencimento sem adimplemento, é tão grande ou maior do que a que se verificava no momento em que o empréstimo é feito e a garantia constituída. 
direito sobre o sangue do devedor, que não poderia assim ser derramado na excussão. Tal solução frustra os direitos de Shylock, que acaba desistindo da garantia e aceita a proposta de pagamento feita pelos amigos de Antonio. Essa é uma descrição muito resumida, e muito pálida, do enredo da peça, que é rico e fascinante. O objetivo de inseri-lo aqui é apenas o de colocar em evidência o caráter universal desse conflito, que organiza todo o enredo de uma peça de SHAKESPEARE.

Esse desfecho causou forte indignação em JHERING, que comenta o assunto no prefácio de $A$ luta pelo direito ${ }^{322}$ :

"E depois, quando a sentença foi proferida, quando toda a dúvida sobre o direito do judeu pelo próprio juiz foi afastada, quando já nenhuma contestação ousa fazer-se ouvir, quando toda assembleia, inclusive o Doge, está submetida à sentença inevitável, quando o vencedor, bem seguro do seu direito, quer executar aquilo a que a sentença o autoriza, o próprio juiz que solenemente reconheceu o seu direito, ilude-o com uma objeção, com uma astúcia tão miserável e tão nula que nem é digna de uma reputação séria.

Pois então há porventura carne que não contenha sangue? O juiz que reconhecia a Shylock o direito de cortar uma libra da carne do corpo de Antonio reconhecia-lhe por isso mesmo o direito ao sangue, sem o qual não pode há hipótese de haver carne, e aquele que tem o direito de cortar uma libra pode levar menos se quiser" ${ }^{323}$.

Sem indignação e, ao contrário, com algum fascínio, a peça de SHAKESPEARE é também comentada por ASCARELLI ${ }^{324}$. O principal ponto destacado por esse autor, em relação ao Mercador de Veneza, é a complexidade do processo de interpretação jurídica. A atividade de interpretação, para esse autor, caminharia entre (a) a vinculação ao direito posto e (b) a criação de sentidos novos para as normas, de

\footnotetext{
${ }^{322}$ R. von JHERING. A luta pelo direito. $16^{\mathrm{a}}$ edição. Trad. João Vasconcelos. Rio de Janeiro, Forense, 1996.

${ }^{323}$ R. von JHERING. A luta pelo direito. $16^{\mathrm{a}}$ edição. Trad. João Vasconcelos. Rio de Janeiro, Forense, 1996. p. XII-XIII.

${ }^{324}$ T. ASCARELLI. Antigone e Porzia. In: Problemi giuridici. t. I. Milano, Giuffrè, 1959. p. 5-15.
} 
início não antevistos, como forma de atender às exigências cambiantes da vida moral, econômica e social. Essa atitude criativa, por vezes, vai longe demais, e SHAKESPEARE parece fazer troça do caráter inusitado dos resultados a que pode se prestar a interpretação jurídica.

Há na literatura, no cinema e na vida outros tantos exemplos intrigantes dos sentimentos que costumam ser dirigidos aos que emprestam a juros e tomam bens em garantia. Em Crime e castigo, é a agiota Alyona Ivanovna quem é assinada por Raskólnikov ${ }^{325}$. Na recente filmagem do Fausto, de GOETHE, dirigida por SoKUROV (2011), Mefistófeles é caracterizado justamente como um agiota, que administra uma casa de penhores, perante a qual teriam sido dados em garantia todos os bens da família de Gretchen ${ }^{326}$. É digno de registro, ainda, o relato do Prof. Pedro Dallari, que atuou como membro de comissão de verificação enviada pela Organização dos Estados Americanos, a comunidades depauperadas situadas na fronteira entre a Colômbia e o Equador. Muito distantes de uma efetiva presença do Estado, tais comunidades estavam dominadas por traficantes de drogas que, com os recursos financeiros advindos dessa atividade, também se dedicavam a emprestar dinheiro a juros aos moradores. Segundo o relato, como os mutuários simplesmente não dispunham de bens de valor econômico que pudessem servir de garantia, o que

\footnotetext{
${ }^{325}$ F. Dostoyevsky. Crime and punishment. Trad. David McDuff. London, Penguin Books, 1991. É particularmente ilustrativa a passagem em que Raskolnikov, necessitado de dinheiro, vai à agiota buscar novo empréstimo, oferecendo em penhor um relógio de aço que alega ter pertencido a seu pai. Como já havia débitos anteriores, vencidos e não pagos, o jovem estudante pede paciência e lembra à credora que pagará mais um mês de juros. A resposta que recebe é a seguinte: "Dearie, it's up to me whether I'm patient or whether I sell what you pawned this very day" Em tradução livre: "Meu querido, eu que decido sou paciente ou se vendo o que você empenhou hoje mesmo". Na continuação da cena, há uma negociação, em que a agiota menospreza o valor do relógio que alegadamente pertencera ao pai do estudante endividado. Chegam ambos enfim a um acordo, pelo qual haveria novo empréstimo de "um rublo e meio", com juros pagos adiantados. Todavia, após se apossar do relógio e se ausentar para buscar o dinheiro, a senhora efetua os cálculos, cobra antecipadamente os juros e excute diretamente o débito anterior, deduzindo-o do valor do novo empréstimo. Dirige-se a Raskolnikov nos seguintes termos: "Now, then, dearie: the interest's ten per cent a month, so on a rouble fifty you owe me fifteen copecks, payable in advance. You also owe me twenty copecks on the two roubles you had before. That comes to thirty-five copecks. So what you get for your watch is a rouble fifteen. Here you are." Em tradução livre: "Então, meu querido: os juros são de dez por cento ao mês, então sobre o rublo e meio você me deve quinze 'copecks', a serem pagos adiantados. Você também me deve vinte 'copecks' dos dois rublos que você tomou emprestados antes. Isso tudo dá trinta e cinco 'copecks'. Então o que você leva pelo seu relógio é um rublo e quinze 'copecks'. Aqui está". Confuso, mas sem alternativa, Raskolnikov aceita o negócio e anuncia que talvez volte, em um dia ou dois, na posse de algum item de prata, para novo empréstimo ou pagamento dos anteriores. (p. 38-39).

${ }^{326}$ Faust. Diretor: Alexander Sokurov. Produtor: Andrey Sigle. Roteiro de Alexandr Sokurov, Marina Koreneva e Yuri Arabov. S. Petersburgo, 2011, 134 minutos.
} 
se empenhava nos empréstimos eram as fotografias da família, a indicar que era a própria vida que estava dada em garantia ${ }^{327}$. No julgamento do Recurso Extraordinário n. ${ }^{\circ}$ 60.699/GB, analisado no item 5.2.1, o Min. Aliomar Baleeiro, não se sabe infelizmente em que tom, comenta que "Todos os demagogos romanos apoiavam os devedores". Inúmeros outros relatos, tanto remotos como recentes, de situações de endividamento, outorga e excussão de garantias podem ser encontrados no cativante estudo antropológico de GRAEBER ${ }^{328}$.

Dessas observações todas, não se pretende aqui extrair nenhuma conclusão específica. A apresentação, muito breve, desses elementos da cultura visa apenas a apontar a necessidade de se desenvolver uma consciência mais apurada da dimensão, complexidade e profundidade dos conflitos humanos subjacentes à proibição do pacto comissório. Acredita-se que essa consciência pode cumprir um papel não desprezível nas tomadas de decisões legislativas e mesmo jurisprudenciais que versem sobre o tema.

Praticar o direito significa, sobretudo, deliberar, julgar ${ }^{329}$. Por isso, desenvolver a consciência a que se fez referência no parágrafo anterior é um modo de cultivar a virtude da sabedoria prática, cujo exercício representa uma contribuição útil que aqueles que estudam o direito podem oferecer à sociedade ${ }^{330}$.

\footnotetext{
327 A experiência que permitiu essa observação está relatada em P.B.A DALLARI. A comissão de verificação da OEA para as relações entre Colômbia e Equador. In: A América Latina e os conflitos fronteiriços. Org. Clóvis Brigagão. Rio de Janeiro, EDUCAM/Konrad Adenauer Stiftung, 2010. p. 4965. A informação sobre a prática de tomar as fotografias da família em garantia foi obtida em entrevista feita com o autor do artigo, em 9 de janeiro de 2013.

${ }^{328}$ D. GRABER. Debt: the first 5.000 years.

329 F.K. COMParato. Discurso de posse como Professor Titular da Faculdade de Direito da Universidade de São Paulo. Revista da Faculdade de Direito da Universidade de São Paulo. v. LXXI. São Paulo, USP, 1976. p. 325-340: “O próprio do jurisprudente, já disse, é saber deliberar, isto é, julgar e distinguir entre boas e más ações, valorar os atos humanos, compor interesses. (...) Qualquer que seja sua posição na sociedade - como legislador, magistrado, advogado, consultor ou docenteo jurisperito atua como julgador." (p. 329).

${ }^{330}$ Em sentido muito próximo às ideias de F.C. COMPARATO, citadas na nota anterior, mas com densa fundamentação na tradição da Common Law e do direito norte-americano em especial, cf. a obra de A. T. Kronman. The lost lawyer. Failing ideals of the legal profession. Cambridge, The Belknap Press of the Harvard University Press, 1993; em especial os respectivos capítulos 2 e 3, dedicados, respectivamente, às virtudes da sabedoria prática e da fraternidade política e, à propensão da profissão jurídica ao exercício dessas virtudes.
} 


\section{CONCLUSÕES.}

Os itens 4.7, 4.8 e 4.9: (a) resumem as principais conclusões alcançadas no capítulo central da tese e (b) apontam as propostas de aperfeiçoamento do direito vigente que delas decorrem.

O item 5.4 sintetiza o movimento pendular da jurisprudência dos tribunais superiores brasileiros sobre o tema do trabalho. Nesse último ponto, é notória e assumida a mudança de posicionamento do STJ, em relação ao entendimento que passou a prevalecer no STF a partir de 1973. Mas nem sempre é sublinhado que essa orientação do STJ, aparentemente nova, em verdade retoma as diretrizes que predominavam no STF antes de 1973.

O que de mais essencial se construiu nos capítulos 2 e 3, por sua vez, está decantado nos itens 2.3.6 e 2.3.7, e 3.1.11 e 3.3, respetivamente.

Não há utilidade em repetir aqui o que ali já se disse. Mais proveitoso é usar esta oportunidade para circunstanciar a consecução do objetivo último do trabalho, que é apresentar contribuição original à ciência jurídica brasileira.

Nesse ponto, as normas da Universidade de São Paulo são silentes sobre o que se deva entender por contribuição original. É possível, porém, encontrar orientações valiosas a esse respeito no regulamento de doutorado da London School of Economics, que também toma como base para a outorga do título de doutor a mencionada ideia de contribuição original. Esse regulamento estabelece como critérios para a aferição da originalidade: (a) a descoberta de fatos novos, ou (b) a demonstração de capacidade crítica independente, ou (c) ambos os anteriores ${ }^{331}$.

Acredita-se que a tese desenvolveu, em primeiro lugar, uma crítica independente à proibição do pacto comissório. Foram refutadas as justificativas correntes para a proibição existentes no direito brasileiro (proteção do devedor, proibição da usura). E foram também objeto de crítica independente as demais

331 P. DunLEAVY. Authoring a PhD. How to plan, draft, write \& finish a doctoral thesis or dissertation. London, Palgrave MacMillan, 2003. p. 27. 
justificativas discutidas, sobretudo no direito italiano, relativas: (i) à indisponibilidade dos meios judiciais de realização coativa das garantias (BETTI, CARNEVALI); e (ii) ao interesse social em impedir a difusão do pacto comissório (BIANCA). A tese viu mérito, por outro lado, no argumento, originalmente formulado por CARNELUTTI, e desenvolvido também por ANDRIOLI, que relaciona a proibição do pacto comissório com a preservação dos interesses dos demais credores do devedor e da par conditio creditorum.

Ademais - e diante do discurso hoje dominante sobre o tema no direito brasileiro, tanto na doutrina como nos tribunais superiores - sustenta-se que houve ainda descoberta de fato novo pela tese. Ele consiste na definição de que o aspecto verdadeiramente deletério da celebração de pacto comissório reside na possível desproporção entre o valor de mercado do bem objeto de garantia e o valor da obrigação garantida. Havendo meios de assegurar a inexistência de excesso, ou de exigir de antemão que tal excesso seja restituído ao devedor (garantia já nominada em dinheiro, ou com valor de mercado facilmente aferível), elimina-se o que há de reprovável no pacto comissório.

Entende-se ser também original verificar que essa conclusão é a um só tempo condizente: (a) com a sistemática subjacente ao Article 9 do UCC, diploma normativo bastante influente nas recentes reformas legislativas feitas sobre a matéria ao redor do mundo; e (b) com a tradição mais remota do direito luso-brasileiro, na qual autores como CORRÊA Telles e COElHO DA Rocha defendiam a validade do pacto comissório quando transferência da propriedade do devedor ao credor se desse por "preço justo".

A demonstração mais detida dessa contribuição original, a bem da verdade, permeou tudo o quanto se procurou construir no decorrer do trabalho, que ora se encerra. A tarefa que se assinala para este último item é basicamente de síntese, que resta aqui, também ela, concluída. 


\section{BIBLIOGRAFIA.}

AleXY, Robert. Teoria da argumentação jurídica. Trad. Zilda Hutchinson Schild Silva e revisão de Claudia Toledo. São Paulo, Landy Editora, 2005.

Amaral, Francisco. Direito civil. Introdução. $4^{\mathrm{a}}$ edição. Rio de Janeiro, Renovar, 2002 .

Amaral Neto, Francisco dos Santos. A alienação fiduciária em garantia no direito brasileiro. In: Contratos em espécie: atribuição patrimonial e garantia (organizadores Gustavo Tepedino e Luiz Edson Fachin). São Paulo, Revista dos Tribunais, 2011 (Coleção doutrinas essenciais: obrigações e contratos, v. 5). p. 315333.

ANDRADE, Manuel Domingues de. Teoria geral da relação jurídica. v. I. Sujeitos e objecto. Coimbra, Coimbra Editora, 1983.

Andrioli, Virgilio. Commentario del Codice Civile a cura di Antonio Scialoja e Giuseppe Branca. Libro Sesto. Tutela dei diritti. Art. 2.740-2.899. Bologna, Nicola Zanichelli Editore, 1945.

ANGELONI, Franco. Sulla responsabilità disciplinare del notaio che roghi un atto contenente un presunto patto commissorio. Contratto e Impresa. Padova. v.16. n.3. p.1086-100. set./dic. 2000.

Antunes Varella, João Mattos. Direito das obrigações. v. 2. Rio de Janeiro, Forense, 1979.

Das obrigações em geral. v. I. e II. $7^{a}$ edição.

Coimbra, Almedina, 2006. 
ARMOUR, John. The law and economics debate about secured lending: lessons for european lawmaking? Consultado em http://ssrn.com/abstract=1118030; acesso em 9.7.2011.

ARrAngIO-RuIZ, Vincenzo. Istituzioni di diritto romano. 14 ${ }^{\mathrm{a}}$ ed. (Ristampa). Napoli, Casa Editrice Eugenio Jovene, 2006.

AsCARELl, Tullio. Antigone e Porzia. In: Problemi giuridici. t. I. Milano, Giuffrè, 1959. p. 5-15.

Negócio jurídico indireto. Lisboa, Jornal do Foro, 1965.

Assis, Araken de e Malachini, Edson Ribas. Comentários ao código de processo civil. v. 10. (arts. 736 a 795). São Paulo, Revista dos Tribunais, 2001.

Manual da execução. $12^{\mathrm{a}}$ edição. São Paulo, Revista dos

Tribunais, 2009.

Aynes, Laurent e CROCQ, Pierre. Les sûretés. La publicité foncière. 4éme édition. Paris, Defrénois, 2009.

BARBIERA, Lelio. Responsabilità patrimoniale. Disposizioni generali. In: Il Codice Civile. Commentario diretto da Piero Schlesinger. Art. 2740-2744. Milano, Giuffrè, 1991.

BAR-GILL, Oren e WARREN, Elizabeth. Making credit safer. University of Pennsilvania Law Review. v. 157. 2008. p. 101-201.

BEBCHUK, Lucian Ayre e FRIED, James M. The uneasy case for the priority of secured claims in bankruptcy. 105 Yale Law Journal 857 (1996).

BECQUE, Emile. Sûretés réelles. $1^{\text {ere }}$ partie. In : Traité pratique de droit civil français par Marcel Planiol et George Ripert. 2a. ed.. Paris, LGDJ, 1953. 
BESSONE, Darcy. Direitos reais. 2a edição. São Paulo, Saraiva, 1996.

BETTI, Emilio. Su gli oneri e i limiti dell'autonomia privata in tema di garanzia e modificazione di obbligazioni. Rivista del Diritto Commerciale e del Diritto Generale delle Obbligazioni. v. XXIX, parte II. Milano, Francesco Vallardi, 1931. p. 689 a 715.

Istituzioni di diritto romano. v. 2. Parte prima. Padova, Cedam, 1962.

Teoria geral do negócio jurídico. t. I. Trad. Fernando de Miranda.

Coimbra, Coimbra Editora, 1969.

Bevilacqua, Clovis. Código Civil dos Estados Unidos do Brasil. v. III. Rio de Janeiro, s/ed., s/d.

BianCA, C. Massimo. Il divieto del patto comissorio. Milano, Giuffré, 1957.

Patto comissorio (voce). Novissimo Digesto Italiano (diretto da Antonio Azara e Ernesto Eula). XII.Torino, UTET, 1965.

BíBLIA DE JERUSALÉM. São Paulo, Paulus, 2002.

BLACK, Henry Campbell. Black's law dictionary. $6^{\text {th }}$ edition. St. Paul, Minnessota, West Group, 1990.

Bonfante, Pietro. Diritto romano. Ristampa a cura di Giuliano Bonfante e Giuliano Crifò. Milano, Giuffrè, 1976.

BRANCO, Gerson L. C.. Função social dos contratos - interpretação à luz do Código Civil. São Paulo, Saraiva, 2009.

Brugi, M.I. Patto comissório (voce). Enciclopedia Giuridica. Roma, Instituto dela Enciclopedia Italiana (Treccani), 2010. 
Bulhões PedreIRA, José Luiz. Finanças e demonstrações financeira das companhias (conceitos fundamentais). $2^{\text {a }}$ edição. Rio de Janeiro, Forense, 1989.

BURDESE, Alberto. Lex commissoria e ius vendendi nella fiducia e nel pignus. Torino, Giappichelli, 1949.

BuZAID, Alfredo. Do concurso de credores no processo de execução. São Paulo, Saraiva, 1952.

CARnElutTI, Francesco. Note sul patto commissorio. In: Studi di diritto processuale. v. I. Padova, Cedam, 1925. p. 487 e ss. Também publicado na Rivista del Diritto Commerciale e del Diritto Generale delle Obligazioni. Vol.XIV, parte II. Milano, Francesco Vallardi, 1916.

Carnevali, Ugo. Patto comissório (voce). In: Enciclopedia del diritto. XXXII. Milano, Giuffré, 1982. p. 499-506.

Carvalho, Orlando de. Negócio jurídico indirecto (teoria geral). In: Escritos. Páginas de direito. Coimbra, Almedina, 1998. p. 35-162.

CARVAlho de MendonçA, Joaquim Xavier. Tratado de direito comercial brasileiro. $5^{\text {a }}$ edição. v. VI, parte 2. Rio de Janeiro, Freitas Bastos, 1956.

Carvalho Santos, J.M. Código civil brasileiro interpretado. Principalmente do ponto de vista prático. Direito das coisas (arts. 755-862). v. X. 9a edição. Rio de Janeiro, São Paulo, Livraria Freitas Bastos, 1964.

Carvalhosa, Modesto. Comentários à lei de sociedades anônimas. $2^{\circ}$ v. $4^{\text {a }}$ edição. São Paulo, Saraiva, 2008. 
CASTRO, Lincoln Antônio de. Anátema ao pacto comissório. Revista Magister de Direito Empresarial, Concorrencial e do Consumidor. Porto Alegre. v.1. n.4. p.1123. ago./set. 2005.

Chalhub, Melhim Namem. Negócio fiduciário. Alienação fiduciária. Cessão fiduciária. Securitização. $3^{a}$ edição. Rio de Janeiro, Renovar, 2006.

COElHO DA RochA, Manuel Antonio. Instituições de direito civil portuguez, para uso de seus discípulos. t. II. $2^{\mathrm{a}}$ edição. Coimbra, Imprensa da Universidade, 1848.

COMPARATO, Fabio Konder. Esssai d'analyse dualiste de l'obligation en droit privé. Paris, Dalloz, 1964.

O seguro de crédito. São Paulo, Revista dos Tribunais, 1968.

Discurso de posse como Professor Titular da Faculdade de Direito da Universidade de São Paulo. Revista da Faculdade de Direito da Universidade de São Paulo. v. LXXI. São Paulo, USP, 1976. p. 325-340.

Pedido ajuizado por credores trabalhistas. Se estão eles adstritos a renunciar a seu privilégio. In: Estudos e pareceres de direito empresarial. Rio de Janeiro, Forense, 1978. p. 411-417.

Legitimidade da fazenda pública para ajuizar pedido de falência. In: Ensaios e pareceres de direito empresarial. Rio de Janeiro, Forense, 1978. p. 418-431.

O direito brasileiro na visão de Tullio Ascarelli. In: Novos ensaios e pareceres de direito empresarial. Rio de Janeiro, Forense, 1981. p. $1-14$. 
Natureza jurídica das bolsas de valores e delimitação do seu objeto. Revista de direito mercantil, industrial, econômico e financeiro. São Paulo. n. 60. 1985.

Funções e disfunções do resgate acionário. In: Direito empresarial. Estudos e pareceres. São Paulo, Saraiva, 1995. p. 120-130.

Notas retificadoras sobre seguro de crédito e fiança. $\underline{\text { In: }}$ Direito empresarial. Estudos e pareceres. São Paulo, Saraiva, 1995. p. 438-449.

Sucessões empresariais. In: Revista dos Tribunais, n. 747, p. 793-799. São Paulo (jan. 1998).

Continentino, Mucio. Da cláusula penal no direito brasileiro. São Paulo, Saraiva, 1926.

CORRÊA DE OlIVEIRA, José Lamartine. A dupla crise da pessoa jurídica. São Paulo, Saraiva, 1979.

A parte geral do anteprojeto de Código Civil. In: Obrigações e contratos: estrutura e dogmática (organizadores Gustavo Tepedino e Luiz Edson Fachin). São Paulo, Revista dos Tribunais, 2011 (Coleção doutrinas essenciais; v. 1). p. 169-193.

Correa Telles, José Homem. Digesto portuguez ou Tractado dos modos de adquirir a propriedade de a gozar e administrar e de a transferir por derradeira vontade para servir de subsídio ao Novo Código Civil. t. III. 5a edição. Coimbra, Livraria J. Augisto Orcel, 1860.

CROCQ, Pierre. The recent influence of insolvency law on the evolution of security in French law. In: Current issues in European financial and insolvency law. Perspectives from France and the UK. Edited by Wolf-Georg Ringe, Louise Gullifer and Philippe Théry. Oxford and Portland Oregon, Hart Publishing, 2009. p. 129-136. 
CRUZ, Sérgio Lúcio de Oliveira e. Classificação dos créditos na falência. In: A nova lei de falências e de recuperação de empresas - Lei $n^{\circ}{ }^{\circ} 11.101 / 05$ (coord. Paulo Penalva Santos). Rio de Janeiro, Forense, 2007. p. 205-221.

Cubeddu, Maria Giovanna. Patto commissorio e vendita conpatto di riscatto: la risposta delle sezioni unite. Rivista di Diritto Civile. Padova. v.36. n.5. p.615-30. sept./ott. 1990.

DAllari, Pedro Bohomoletz de Abreu. A comissão de verificação da OEA para as relações entre Colômbia e Equador. In: A América Latina e os conflitos fronteiriços. Org. Clóvis Brigagão. Rio de Janeiro, EDUCAM/Konrad Adenauer Stiftung, 2010.

DAM, Kenneth W.. Credit markets, creditor's rights and economic development. John M. Olin Law and Economics Working Paper n. 281 (2D Series). The Law School. The University of Chicago. Consultado em http://ssrn.com/abstract_id=885198; acesso em 28.12.2012.

De Chiara, José Tadeu. Moeda e ordem jurídica. São Paulo, Tese de doutorado apresentada à Faculdade de Direito da Universidade de São Paulo, 1986.

De Cores, Carlos e Gabrielli, Enrico. El nuevo derecho de las garantias reales. Estudio comparado de las recientes tendencias en materia de garantias reales mobiliarias. Bogotá, Temis, 2008.

De Nictolis, Rossana. Divieto del patto commissorio, alienazioni in garanzia e salelease-back. Rivista di Diritto Civile. Padova. v.37. n.5. p.535-69. sett./ott. 1991.

DINAMARCO, Candido Rangel. Instituições de direito processual civil. v. I. $6^{\mathrm{a}}$ edição. São Paulo, Malheiros, 2009.

Dostoyevsky, Fyodor. Crime and punishment. Trad. David McDuff. London, Penguin Books, 1991. 
DunLEAVY, Patrick. Authoring a PhD. How to plan, draft, write \& finish a doctoral thesis or dissertation. London, Palgrave MacMillan, 2003.

ENEI, José Virgílio Lopes. Project finance. São Paulo, Saraiva, 2007.

EsPínOLA, Eduardo. Os direitos reais limitados ou direitos sobre coisa alheia e os direitos reais de garantia no direito brasileiro. Rio de Janeiro, Conquista, 1958.

European BANK For ReCONSTRUCTION AND Development. Model Law on Secured Transactions. Consultado em http://www.ebrd.com/downloads/legal/secured/modellaw.pdf; acesso em 28.12.2012.

FABIANI, Emerson Ribeiro. Direito e crédito bancário no Brasil. São Paulo, Saraiva/FGV, 2011.

FACHIN, Luiz Edson. Comentários ao código civil (coord. Antonio Junqueira de Azevedo). v. 15. Parte especial. Do direito das coisas (arts. 1.277 1.368). São Paulo, Saraiva, 2003.

FELIU REY, Manuel Ignacio. La prohibicion del pacto comissório y la opcion en garantia. Madrid, Editorial Civitas, 1995.

FERraz JR., Tercio Sampaio. Introdução ao estudo do direito. Técnica, decisão, dominação. $2^{a}$ edição. São Paulo, Atlas, 1996.

Ato de julgar e senso de justiça. In: Estudos de filosofia do direito. Reflexões sobre o poder, a liberdade, a justiça e o direito. $3^{\text {a }}$ edição. São Paulo, Atlas, 2009. p. 289-307.

Flume, Werner. El negocio jurídico. Parte general del derecho civil. Tomo segundo. 4 edição. Trad. José Maria Miguel Gonzalez e Esther Gómez Calle. Madrid, Fundacion Cultural del Notariado,1998. 
Fraga, Affonso. Direitos reaes de garantia. Penhor, anticrese e hipoteca. São Paulo, Saraiva, 1933.

FrEIRE, Laudelino. Grande e novíssimo dicionário da língua portuguesa. v. II. Rio de Janeiro, José Olympio Editora, 1957.

FulgÊNCIOK, Tito. Direito real de hipoteca. v. I. $2^{\text {a }}$ edição. Atualizada por José de Aguiar Dias. Rio de Janeiro, Forense, 1960.

GILMORE, Grant. Security interests in personal property. 2v. New Jersey, The Law Book Exchange, 1999 (reimpressão da edição de 1965).

GIRARD, Paul Frederic. Manuel elementaire de droit romain. $4^{\mathrm{a}}$ ed.. Paris, Arthur Rousseau, 1906.

GiTTI, Gregorio. Divieto del patto commissorio, frode alla legge, 'sale and lease back'. Rivista trimestrale di diritto e procedura civile. XLVII. n. 2. Giugno, Giuffrè, Milano, 1993. p. 457-492.

GOMES, Orlando. Introdução ao direito civil. 12a edição. Atualizador: Humberto Theodoro Jr. Rio de Janeiro, Forense, 1996.

Direitos reais (atualizada por Luiz Edson Fachin). 19ª edição. Rio de Janeiro, Forense, 2008.

Perfil dogmático da alienação fiduciária. In: Contratos em espécie: atribuição patrimonial e garantia (organizadores Gustavo Tepedino e Luiz Edson Fachin). São Paulo, Revista dos Tribunais, 2011 (Coleção doutrinas essenciais: obrigações e contratos, v. 5). p. 475-481.

Graeber, David. Debt: the first 5.000 years. New York, Melville House Publishing, 2011. 
GUARINO, Antonio. Diritto privato romano.12a ed.. Napoli, Jovene, 2001.

HADDAD, Luís Gustavo. Função social do contrato: um ensaio sobre seus usos e sentidos. São Paulo, Dissertação de mestrado apresentada à Faculdade de Direito da Universidade de São Paulo, 2009.

Hagedorn, Richard B. Secured transactions (in a nutshell). St. Paul, Minnessota, Thomson/West, 2007.

HANSmAnn, Henry e KraAKMAN, Reinier et allii. The anatomy of corporate law. A comparative and functional approach. $2^{\text {nd }}$ edition. Oxford, Oxford University Press, 2009.

Toward unlimited shareholder

liability for corporate torts. 100 Yale Law Journal 1879 (1991)

HART, Herbert L. A. The concept of law. 2nd. ed. Oxford, Oxford University Press, 1997.

Haselmann, R, Pistor, K. e Vig, V.. How Law Affects Lending. Consultado em http://ssrn.com/abstract=846665; acesso em 9.7.2011.

Hedemann, Justus Wilheim. Derechos reales. v. II. Version española de Jose Luis Diez Pastor y Manuel Gonzalez Enriquez. Madrid, Editorial Revista de Derecho Privado, 1955.

Hespanha, Antonio Manuel. Cultura jurídica europeia. Coimbra, Almedina, 2012.

JAEGER, Pier Giusto. La separazione del patrimônio fiduciario nel falimento. Milano. Giuffrè, 1968.

JHERING, Rudolf von. A luta pelo direito. $16^{\mathrm{a}}$ edição. Trad. João Vasconcelos. Rio de Janeiro, Forense, 1996. 
JuglaRT, Michel de. Sûretés - publicité foncière. v. I. In: Leçons de droit civil. t. III. (Henri, Léon et Jean Mazeau). 3a ed.. Paris, Montchrestien, 1968.

JunqueIRA De AZEVEDo, Antonio. Negócio jurídico. Existência, validade e eficácia. $3^{\text {a }}$ edição. São Paulo, Saraiva, 2000.

Insuficiências, deficiências e desatualização do projeto de Código Civil (atualmente, código aprovado) na questão da boa-fé objetiva nos contratos. In: Ensaios e pareceres de direito privado. São Paulo, Saraiva, 2004.

O direito pós-moderno e a codificação. In: Ensaios e pareceres de direito privado. São Paulo, Saraiva, 2004.

KoschaKer, Paul. Europa y el derecho romano. Trad. José Santa Cruz Teigeiro. Madrid, Editorial Revista de Derecho Privado, 1955.

Kronman, Anthony T.. The lost lawyer. Failing ideals of the legal profession. Cambridge, The Belknap Press of the Harvard University Press, 1993.

Larenz, Karl. Metodologia da Ciência do Direito. $2^{\mathrm{a}}$ edição. Trad. José Lamego. Revisão de Ana de Freitas. Lisboa, Calouste Gulbenkian, 1989.

LEÃES, Luiz Gastão Paes de Barros. O leasing é uma operação financeira? Revista de direito mercantil, industrial, econômico e financeiro. n. 35. p. 11-24. 1979.

LE Goff, Jacques. As raízes medievais da Europa. Trad. Jaime A. Clasen. Petrópolis, Editora Vozes, 2007.

Liebman, Enrico Tullio. Processo de execução. São Paulo, Saraiva, 1946.

Penhor. Retrovenda (parecer). In: Contratos em espécie: atribuição patrimonial e garantia (organizadores Gustavo Tepedino e Luiz Edson 
Fachin). São Paulo, Revista dos Tribunais, 2011 (Coleção doutrinas essenciais: obrigações e contratos. v. 5). p. 77-81.

LIMA, Alvino. A fraude no direito civil. São Paulo, Saraiva, 1965.

LiQuidato, Alexandre Gaetano Nicola. O contrato de penhor. Tese de doutorado apresentada à Faculdade de Direito da Universidade de São Paulo. São Paulo, 2012.

LoPucki, Lynn M. e Warren, Elizabeth. Secured credit. A Systems approach. Sixth edition. Austin, Wolters Kluwer, 2009.

LUMINOSO, Angelo. Alla ricerca degli arcani confini del patto commissorio. Rivista di Diritto Civile. Padova. v.36. n.2. p.219-242. mar./apr. 1990.

MacCormick, Neil. Argumentação jurídica e teoria do direito. Trad. Waldea Barcellos. São Paulo, Martins Fontes, 2006.

Rhetoric and the Rule of Law. A theory of legal reasoning.

Oxford, Oxford University Press, 2005.

MCCORMACK, Gerard. Secured credit and the harmonization of law. The UNCITRAL experience. Cheltenham/Northhampton, Edward Elgar, 2011.

MACKELDEY, Ferdinand. Manuel de droit romain. $3^{\mathrm{a}}$ edição. Trad. J.Beving, Bruxelles, Société Typographique Belge, 1846.

MANN, Ronald J. Explaining the pattern of secured credit. Harvard Law Review. v. 110. n. 625. p. 625-683. 1997.

MARCONDES, Sylvio. Restituição na lei falimentar e a figura especial do art. $76, \S 2^{\circ}$. In: Problemas de direito mercantil. São Paulo, Max Limonad, 1970. p. 339-366. 
Da fraude contra credores; falência e alienação de estabelecimento. In: Questões de direito mercantil. São Paulo, Saraiva, 1977. p. 125147.

Martinez, Pedro Romano e DA PonTe, Pedro Fuzeta. Garantias de cumprimento. $4^{\mathrm{a}}$ edição. Coimbra, Almedina, 2003.

MAtos, Isabel Andrade de. O pacto comissório. Contributo para o estudo do âmbito da sua proibição. Coimbra, Almedina, 2006.

MAUSS, Marcel. The gift: forms and functions of exchange in archaic societies. Trad. Ian Cunnison. Mansfield Centre, Martino Publishing, 2011.

Maximiliano, Carlos. Hermenêutica e aplicação do direito. $16^{\mathrm{a}}$ edição. Rio de Janeiro, Forense, 1996.

MeDicus, Dieter. Tratado de las relaciones obligacionales. 2 v. Trad. Ángel Martínez Sarrión. Barcelona, Bosch, 1995.

Mello, Marcos Bernardes de. Teoria do fato jurídico. Plano da existência. $7^{\mathrm{a}}$ edição. São Paulo, Saraiva, 1995.

Teoria do fato jurídico. Plano da validade. $2^{\mathrm{a}}$ edição.

São Paulo, Saraiva, 1997.

Teoria do fato jurídico. Plano da eficácia. $1^{a}$ parte.

São Paulo, Saraiva, 2003.

MENEZES LeITÃo, Luís Manuel Telles de. Garantia das obrigações. $2^{\mathrm{a}}$ edição. 2008.

Monteiro, Washington de Barros e MALuf, Carlos Alberto Dabus. Curso de direito civil. Direito das obrigações ( $1^{a}$ parte). $35^{\text {a }}$ edição. São Paulo, Saraiva, 2010. 
civil. Direito das coisas. 37 edição São Paulo, Saraiva, 2003.

MORAES, Walter. Teoria geral e sucessão legítima (programa de direito das sucessões). São Paulo, Revista dos Tribunais, 1980.

Moreira Alves, José Carlos. Alienação fiduciária em garantia. $2^{\mathrm{a}}$ edição. São Paulo, Saraiva, 1979.

A parte geral do projeto de Código Civil brasileiro.

São Paulo, Saraiva, 1984.

A retrovenda. $2^{\mathrm{a}}$ edição. São Paulo, Revista dos

Tribunais, 1987.

As normas de proteção do devedor e o favor debitoris - do Direito Romano ao Direito Latino-Americano. Notícia do direito brasileiro. n. ${ }^{\text {o }}$ 3, $1^{\text {o }}$ semestre de 1997. p. 109-165.

Direito romano. v. I. Rio de Janeiro, Forense, 1999.

O favor debitoris como princípio geral de direito.

Revista do advogado. v. 26, n. 88, p. 98-108, nov., 2006.

Mota Pinto, Carlos Alberto. Teoria geral do direito civil. $3^{\text {a }}$ edição. Coimbra, Coimbra Editora, 1991.

Munhoz, Eduardo Secchi. Comentário ao art. 67 da Lei n. ${ }^{\circ}$ 11.101/05. In: Comentários à lei de recuperação de empresas e falência (coord. Francisco Satiro de Souza Jr. e Antonio Sergio A. de Moraes Pitombo). 2a edição. São Paulo, Revista dos Tribunais, 2007. 
Neves, Celso. Estrutura fundamental do processo civil. Tutela jurídica processual, ação, processo e procedimento. Rio de Janeiro, Forense, 1997.

Comentários ao código de processo civil. v. VII (arts. 646-795). $7^{\mathrm{a}}$ edição. Rio de Janeiro, Forense, 1999.

NonATO, Orosimbo. Fraude contra credores (da ação pauliana). Rio de Janeiro, Editora Jurídica e Universitária, 1969.

OliveIRA, Gleydson Kleber Lopes de. Comentários ao código civil brasileiro. v. XII (Arts. 1.277 a 1.389). Da propriedade, da superfície e das servidões (coord. Arruda Alvim e Teresa Alvim). Rio de Janeiro, Forense, 2004.

ORDENAÇÕES FILIPINAS. Reprodução fac-simile da edição feita por Candido Mendes de Almeida no Rio de Janeiro em 1870. Lisboa, Calouste Gulbenkian, 1985.

Organization of the American States. Model Inter American Law on Secured Transactions. Consultado em http://www.oas.org/dil/Model_Law_on_Secured_Transactions.pdf; 28.12.2012.

Penteado, Luciano de Camargo. Direitos das coisas. São Paulo, Revista dos Tribunais, 2008.

Penteado, Mauro Bardawil. O penhor de ações no direito brasileiro. São Paulo, Malheiros, 2008.

PenteAdO, Mauro Rodrigues. Comentários às disposições preliminares da Lei n. ${ }^{\circ}$ 11.101/05. In: Comentários à lei de recuperação de empresas e falência (coord. Francisco Satiro de Souza Jr. e Antonio Sergio A. de Moraes Pitombo). $2^{\text {a }}$ edição. São Paulo, Revista dos Tribunais, 2007. 
PEREIRA, Caio Mario da Silva. Instituições de direito civil. v. IV. $15^{\mathrm{a}}$ edição. Rio de Janeiro, Forense, 2001.

PereIRA, Lafayette Rodrigues. Direito das coisas. v. II. (coleção História do Direito Brasileiro). Brasília, Senado Federal, 2004.

Pontes de MiRanda, Francisco Cavalcanti. Comentários à Constituição de 1967. t. V. São Paulo, Revista dos Tribunais, 1968.

Tratado de direito privado. t. II. $2^{\mathrm{a}}$ edição. Rio de Janeiro: Borsói, 1972.

Tratado de direito privado. t. III. $3^{\mathrm{a}}$ edição. Rio de Janeiro, Borsói, 1970.

Tratado de direito privado. t. XX. $3^{\mathrm{a}}$ edição. São Paulo, Revista dos Tribunais, 1983.

Tratado de direito privado. t. XXI. $3^{\mathrm{a}}$ edição. São Paulo, Revista dos Tribunais, 1983.

Tratado de direito privado. t. XXII. $3^{\mathrm{a}}$ edição. São Paulo, Revista dos Tribunais, 1984.

Tratado de direito privado. t. XXIX. $3^{\mathrm{a}}$ edição. São Paulo, Revista dos Tribunais, 1984.

Tratado de direito privado. t. XXXIX. $3^{\mathrm{a}}$ edição. São Paulo, Revista dos Tribunais, 1984.

Comentários ao código de processo civil. t. XI. (arts. 736-795). Rio de Janeiro, Forense, 1976. 
Fontes e evolução do direito civil

brasileiro. $2^{\text {a }}$ edição. Rio de Janeiro, Forense, 1981.

PugLiATTI, Salvatore. Esecuzione forzata e diritto sostanziale. Ristampe della Scuola in perfezionamento in diritto civile dell'Univesità di Camerino. Camerino, Edizioni Scientifiche Italiane. 1978.

RABELLO, José Geraldo de Jacobina. Alienação fiduciária em garantia. In: Contratos em espécie: atribuição patrimonial e garantia (organizadores Gustavo Tepedino e Luiz Edson Fachin). São Paulo, Revista dos Tribunais, 2011 (Coleção doutrinas essenciais: obrigações e contratos, v. 5). p. 339-363.

Reale, Miguel. Exposição de Motivos do Código Civil. Diário do Congresso Nacional (Seção I), Suplemento, 14-9-1983.

RENNER, Karl. The institutions of private law and their social functions. Trad. Agnes Schwarzchild. London, Routledge \& Kegan Paul, 1949.

República Federativa do Brasil. Ministério da Fazenda. Secretaria de Política Econômica. Reformas microeconômicas e crescimento de longo prazo. Brasília, 2004, Consultado em http://www.fazenda.gov.br/spe/publicacoes/reformasinstitucionais/estudos/Texto_Ve rsaoFinal5.pdf; acesso em 8.7.2011.

República Federativa do Brasil. Banco Central do Brasil. Notas técnicas do Banco Central do Brasil. n. ${ }^{\circ}$ 35. Maio de 2003. Sistema judicial e mercado de crédito no Brasil (Pedro Fachada, Luiz Fernando Figueiredo e Eduardo Lundberg). Consultado em http://www.bcb.gov.br/pec/notastecnicas/port/2003nt35sistemajudicialmercadocredb rasilp.pdf; acesso em 9.7.2011.

REPUBLIQUE FRANÇAISE. Rapport au Président de la République relatif à l'ordonnance n. ${ }^{\circ}$ 2006-346 du 23 mars 2006 relative aux sûretés. Journal Officiel de 
la République Française, edition de 24 mars 2006 (consultado no sítio da Association Henri Capitant des Amis de la Culture Juridique Française www.henricapitant.org, acesso em 01.10.2012).

Rapport à Monsieur Dominique Perben, Garde des Sceaux, Ministre de la Justice, issue par le Groupe de travail relatif à la reforme du droit des sûretés (consultado no sítio da Association Henri Capitant des Amis de la Culture Juridique Française - www.henricapitant.org, acesso em 01.10.2012).

Restiffe Neto, Paulo e Restiffe, Paulo Sergio. Garantia fiduciária. $3^{\text {a }}$ edição. São Paulo, Revista dos Tribunais, 2000.

RIVA, Ilaria. Il contratto di sale and lease back e il divieto di patto commissorio. Contratto e Impresa. Padova. v.17. n.1. p.300-24. gen./apr. 2001.

RIZZIERI, Juarez Alexandre Baldini. Introdução à economia. In: Manual de economia (organizado pelos Professores do Departamento de Economia da Faculdade de Economia e Administração da Universidade de São Paulo - Diva Benevides Pinho e Marco Antonio Sandoval de Vasconcellos). 2a edição. São Paulo, Saraiva, 1996.

Rodrigues, Silvio. Direito civil. Direito das coisas. v. V. $20^{a}$ edição. São Paulo, Saraiva, 1993.

RopPO, Vicenzo. Nota sopra il divieto del patto commissorio. In: ALPA, Guido; Bessone, Mario; RopPo, Enzo. Rischio contrattuale e autonomia privata. Napoli, Eugenio Jovene, 1982.

Il contratto. In: Tratatto di Diritto Privato (a cura di Giovanni Iudica e Paolo Zatti). Milano, Giuffrè, 2001.

RUBINO, Domenico. La responsabilità patrimoniale. Il pegno. Seconda edizione. Torino, UTET, 1949. p. 5-25. 
SACCO, Rodolfo. Introdução ao direito comparado. Trad. Véra Jacob de Fradera. São Paulo, Revista dos Tribunais, 2001.

SAMUElson, Paul e Nordhaus, William. Economics. 14 $4^{\mathrm{a}}$ edição. New York, MacGraw-Hill, 1992.

Schulz, Fritz. Derecho romano clásico. Trad. José Santa Cruz Teigeiro. Barcelona, Bosch, 1960.

SERPA LOPES, Miguel Maria de. Curso de direito civil. v. III (fontes das obrigações: contratos). $4^{\mathrm{a}}$ edição. Atualizada por José Serpa Santa Maria. Rio de Janeiro, Freitas Bastos, 1991.

SHAKESPEARE, William. The Oxford Shakespeare. The complete works. (General editors Stanley Wells and Gary Taylor). Edited by John Jowett, William Montgomery, Gary Taylor and Stanley Wells. Oxford, Claredon Press, 2005.

SIGMAN, Harry. Security in movables in the United States - UCC Article 9: a basis for comparison. In: Security Rights in Movable Property in European Private Law. Edited by Eva-Maria Kieninger. Cambridge: Cambridge University Press. 2009.

SiLva, Antonio de Moraes. Diccionário da língua portugueza, composto por Antonio de Moraes Silva. t. I. $4^{\mathrm{a}}$ edição. Lisboa, Na impressão régia, 1831.

Silva, OvíDio Batista DA. Ação de imissão de posse. $2^{\text {a }}$ edição. São Paulo, Revista dos Tribunais. 1997.

Curso de processo civil. v. 1. $4^{\mathrm{a}}$ edição. São Paulo, Revista dos Tribunais, 1998.

SoKurov, Alexander (diretor). Faust (filme). Produtor: Andrey Sigle. Roteiro de Alexandr Sokurov, Marina Koreneva e Yuri Arabov. St. Petersburgo, 2011, 134 minutos. 
SouZA JR., Francisco Satiro e PITOMBo, Antonio Sérgio A. de Moraes (coord.). Comentários à lei de recuperação de empresas e falência. $2^{\mathrm{a}}$ edição. São Paulo, Revista dos Tribunais, 2007.

Sztajn, Rachel e Mello Franco, Vera Helena de. Falência e recuperação da empresa em crise. Comparação com as disposições do direito europeu. Rio de Janeiro, Elsevier, 2008.

TalamancA, Mario. Istituzioni di diritto romano. Milano, Giuffrè, 1990.

TeiXeIRA DE Freitas, Augusto. Vocabulário jurídico. t. I. (Coleção clássicos do direito brasileiro. Edição cuidada por Alcides Tomasetti Jr.). São Paulo, Saraiva, 1983.

Consolidação das leis civis. v. I. Edição fac-similar.

Brasília, Superior Tribunal de Justiça, 2003.

Esboço do Código Civil. v. 1 e v. 2. Brasília,

Ministério da Justiça, 1983.

THEODORO JR., Humberto. A insolvência civil. Execução por quantia certa contra devedor insolvente. $5^{\mathrm{a}}$ edição. Rio de Janeiro, Forense, 2003.

TuCCI, Giuseppe. Garanzie sui crediti dell'impresa e tutela dei finanziamenti. Milano, Giuffrè, 1974.

United NATIONS COMmission ON INTERNATIONAL TRADE LAW - UNCITRAL. Legislative guide on secured transactions. Consultado em http://www.uncitral.org/pdf/english/texts/security-lg/e/09-82670_Ebook-Guide_0904-10English.pdf; acesso em 28.12.2012. 
VAlverde, Trajano Miranda. Sociedade por ações (comentários ao decreto-lei $n$. 2.627, de 26 de setembro de 1940). v. II (arts. 74 a 136). $3^{\text {a }}$ edição. Forense: Rio de Janeiro, 1959.

Comentários à lei de falências. v. I e II. $4^{\mathrm{a}}$ edição. Atualizada por J.A. Penalva Santos e Paulo Penalva Santos. Rio de Janeiro, Forense, 1999.

VANZELlA, Rafael Domingos Faiardo. Numerus clausus dos direitos reais $e$ autonomia nos contratos de disposição. Tese de doutorado apresentada à Faculdade de Direito da Universidade de São Paulo, São Paulo, 2009.

VARRONE, Claudio. Il transferimento dela proprietà a scopo di garanzia. Napoli, Eugenio Jovene, 1968.

Venosa, Silvio de Salvo. Direito civil. Direitos reais. v. V. $3^{\text {a }}$ edição. São Paulo, Atlas, 2003.

Código civil comentado. v. XII. Direito das coisas, posse, direitos reais, propriedade. Arts. 1.196 a 1.368 (coord. Álvaro Villaça Azevedo). São Paulo, Atlas, 2003.

ViannA, Marco Aurélio S. Comentários ao novo código civil. v. XVI. Dos direitos reais. Arts. 1.255 a 1.510 (coord. Sálvio de Figueiredo Teixeira). Rio de Janeiro, Forense, 2003.

VILlELA, João Baptista. Da compensabilidade no concurso falencial. Ensaio de contribuição à tutela dos créditos. Tese para doutoramento na Faculdade de Direito da Universidade de Minas Gerais. Belo Horizonte, s/ed., 1963.

Vivante, Cesare. Del contratto di assicurazione - di pegno - di deposito nel magazzini generali. Art. 417-479 Cod. Comm. (Il codice di commercio commentato. 
Coord. Leone Bolaffio, Alfredo Rocco, Cesare Vivante. $6^{a}$ ed. v. VII). Torino, UTET, 1936.

VON TUHR, Andreas. Tratado de las obligaciones. t. I. Trad. W. Roces. Madrid, Reus, 1999.

WARREN, Elizabeth e WeStBROOK, Jay Lawrence. The law of debtors and creditors. Text, cases and problems. Sixth edition. Austin, Wolters Kluwer, 2009.

WARren, Elizabet. Bankruptcy and Article 9. Statutory supplement. Austin, Wolters Kluwer, 2010.

WiACKeR, Franz. História do direito privado moderno. Trad. A.M. Botelho Hespanha. Lisboa, Calouste Gulbenkian, 1980.

Wolff, Martin e RaISER, Ludwig. Tratado de derecho civil. Derecho de cosas. v. II. Trad. Blas Pérez González y José Alguer. Barcelona, Bosch, 1937.

WORLD BANK, 2001. The World Bank principles and guidelines for effective insolvency and creditor rights systems. Washington D.C. - The Worldbank. Consultado em http://documents.worldbank.org/curated/en/2001/04/10465125/world-bankprinciples-guidelines-effective-insolvency-creditor-rights-systems; acesso em 28.12.2012.

Yoshikawa, Eduardo Henrique de Oliveira. Execução extrajudicial e devido processo legal. São Paulo, Atlas, 2010.

ZIMMERMAN, Reinhard. The law of obligations. Roman foundations of the civilian tradition. Oxford, Oxford University Press (Claredon Series), 1996. 


\section{RESUMOS.}

\subsection{Resumo.}

O objetivo central da tese é o de identificar os possíveis fundamentos da proibição do pacto comissório e testá-los mediante contraste com a legislação vigente. Em termos de método, isso é feito como exercício de argumentação jurídica, pautada na ideia de reconstrução racional (MACCORMICK) e na hipótese do legislador racional (FERRAZ JR.). Para alcançar esse objetivo, o trabalho começa por investigar (a) os sentidos dos termos que compõem a locução pacto comissório; e (b) a função e a estrutura da cláusula, que são analisadas sob a premissa teórica da sua licitude. Na sequência, é perquirida a presença da proibição nas legislações estrangeiras e na legislação brasileira. Disso resulta a percepção de que, embora a proibição permaneça largamente presente, há indícios de que ela começa a sofrer erosões, ou de que está a se disseminar uma visão mais clara do seu anacronismo, ou dos limites mais estreitos em que ela se justifica. Na consecução do referido objetivo central, a tese põe à prova, com base na legislação brasileira vigente, os seguintes possíveis fundamentos da vedação: (a) proteção do devedor; (b) repressão à usura; (c) caráter inderrogável da via judicial como forma de execução; (d) interesse social em impedir a difusão do pacto comissório; e (e) preservação da par conditio creditorum. A conclusão que se alcança é que não existe explicação, senão a de cunho apenas histórico, sobre o porquê de a vedação continuar sancionada por nulidade no direito brasileiro. A partir disso, propõe-se a reconstrução de um sentido para a proibição do pacto comissório, baseada na licitude do pacto marciano e na disciplina da excussão das garantias já nominadas em dinheiro. Essa iniciativa identifica como cerne da reprovabilidade do pacto comissório o risco de desproporção entre o montante da dívida e o valor de mercado do bem dado em garantia. Dessa constatação, e do quanto mais resulta da pesquisa, emergem certas sugestões de aperfeiçoamento legislativo. A tese é complementada pela análise dos julgados dos tribunais superiores brasileiros (STF e STJ) que, ao longo dos últimos cinquenta anos, debateram a extensão da proibição do pacto comissório. A parte final do trabalho aponta certas questões da economia e da cultura que se entende estarem também envolvidas na proibição do pacto comissório. 


\subsection{Abstract.}

The thesis' main purpose is to identify the possible reasons for prohibiting the "pacto comissório" and to test them by contrast with the provisions of Brazilian Law. In terms of method, this goal is attained as an exercise of legal reasoning, grounded on the ideas of rational reconstruction (MACCORMICK) and on the assumption of the rational lawmaker (FERRAZ JR.). The essay starts by discussing (a) the meanings of the terms in the expression "pacto comissório" and (b) the function and the structure of the clause, under the theoretical assumption of its conformity with the Law. After such discussion, the thesis points out the presence of the prohibition in certain foreign legislations and also in the Brazilian Laws. This leads to the perception that, although the prohibition remains largely present, there are signs that it is being eroded, or that it is becoming clear that it is outdated, or that may be justified in a much narrower sense. While pursuing its central objective, the essay tries out, in light of Brazilian Law, the following possible reasons for prohibiting the "pacto comissório": (a) the protection of the debtor; (b) the repression to the usury; (c) the judicial foreclosure as the mandatory form for the enforcement of security interests; (d) the social interest in avoiding the dissemination of the "pacto comissório"; and (e) the observance of the par conditio creditorum rule. The conclusion that arises from this test is that there is no explanation, except for a historical one, for the prohibition of the "pacto comissório" to remain sanctioned by nullity in Brazilian Law. The thesis suggests then the reconstruction of a reasonable meaning for the prohibition, which takes into account the legitimacy of the "pacto marciano" and the legal discipline of the security interests over money or money-like assets. This initiative identifies the risk of discrepancy between the amount of the debt and the market value of the collateral as the real core of the rule prohibiting the "pacto comissório". From this conclusion, and from what else is perceived by the research, certain suggestions for enhancing the quality of Brazilian legislation are presented. The essay is complemented by the analysis of the decisions rendered by Brazilian superior courts (STF and STJ) during the last fifty years, regarding the extension of the prohibition of the "pacto comissório". A last part of the thesis points out certain economic and cultural issues that are also considered involved in the prohibition of the "pacto comissório". 


\section{$9.3 \quad$ Résumé.}

L'objectif principal de la thèse est d'identifier les raisons de l'interdiction du pacte commissoire et de tester ses raisons par contraste avec les règles du droit positif brésilien. Dans la une perspective méthodologique, cet objectif est développé comme un exercice de raisonnement juridique, basé sur l'idée de reconstruction rationnelle (MACCORMICK) et sur l'hypothèse du legislateur rationnelle (FERRAZ JR.). Le travail commence par la discussion (a) du sens des mots dans l'expression «pacte commissoire»; et (b) de la fonction et de la structure de la clause, sous 1'hypothèse théorique de sa conformité avec le droit. Alors, la thèse investigue la présence de l'interdiction dans les différentes législations étrangères ainsi que dans les lois brésiliennes. La perception qui emmerge est que, malgré tout, l'interdiction continue à exister, il y a des signaux qu'elle devient plus faible, ou qu'elle n'est pas actuelle ou qu'elle peut être justifiée dans un sens bien limité. Le travail teste, au regard du droit brésilien, les raisons possibles suivantes pour l'interdiction du pacte commissoire: (a) la protection du débiteur; (b) la répression de usure; (c) le caractère inderrogable de la voie judiciaire comme forme d'exécution des sûretés; (d) l'intérêt social à eviter la dissémination du pacte commissoire; e (c) la préservation de la règle de la par conditio creditorum. La conclusion à laquelle on arrive est qu'il n'y a pas d'explication, autre que l'explication historique, pour que l'interdiction du pacte commissoire reste sanctionnée de nullité en droit brésilien. La thèse présente donc une suggestion de reconstruction du sens de l'interdiction, qui considère la legalité du «pacto marciano» et les règle applicables aux sûretés déjà établies sur l'argent ou sur des biens déjà nominées en argent. Cette initiative identifie le risque de difference entre le montant de l'obligation et la valeur sur le marché des biens gagés comme le «coeur» de l'interdiction du pacte commissoire. En consequence de cette conclusion, et des autres résultats de la recherche, la thèse présente quelques suggestions d'amélioration du droit positif brésilien. Le travail est complété par une discussion des décisions des tribunaux supérieurs brésiliens (STF et STJ) qui, pendant les cinquante derrières années, ont analysé l'extension de la prohibition du pacte commissoire. Une partie final est dediée à certaines questions d'économie et de culture qui sont également liés à l'interdiction du pacte commissoire. 